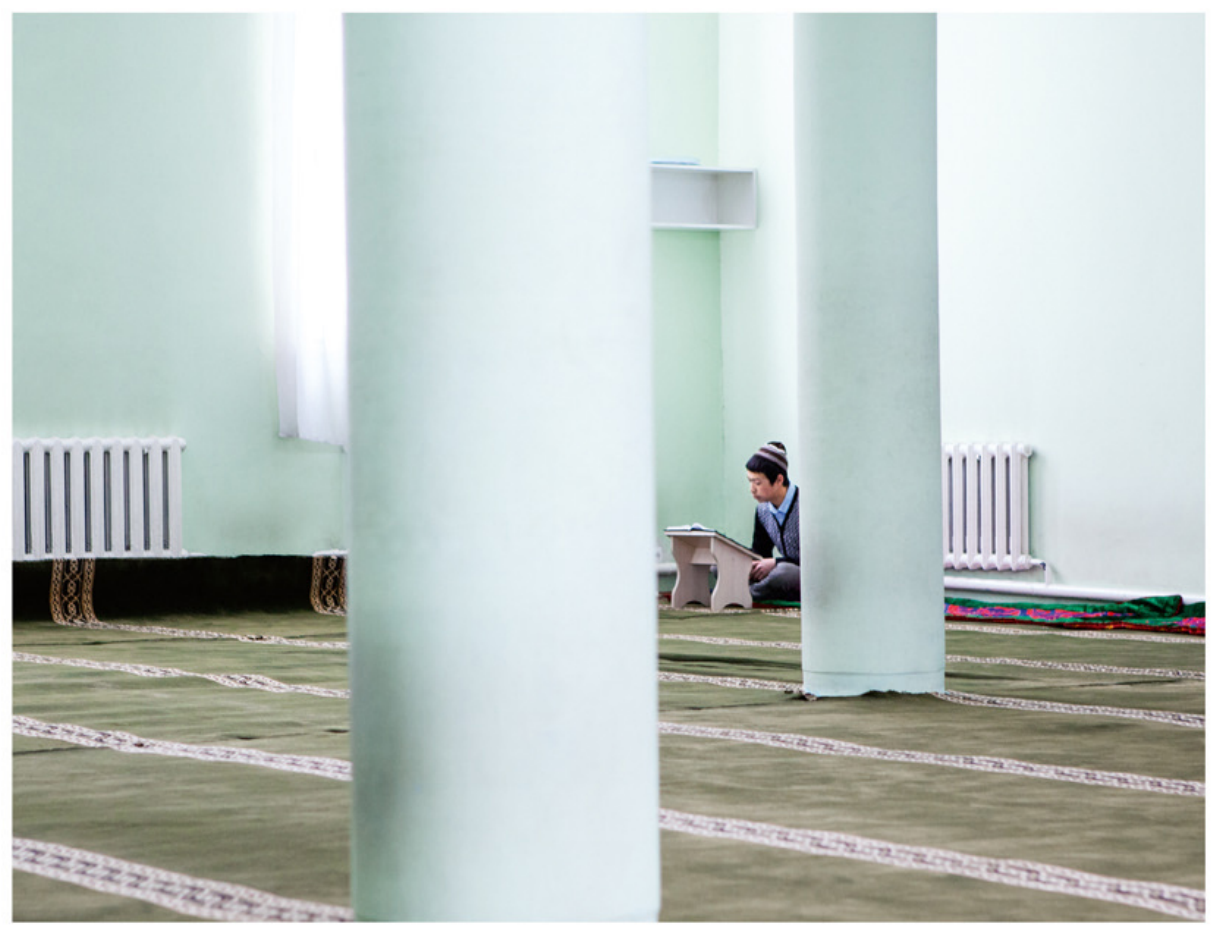

Kathrin Lenz-Raymann

\title{
SECURITIZATION OF ISLAM: A VICIOUS CIRCLE
}

Counter-Terrorism and Freedom of Religion in Central Asia 
Kathrin Lenz-Raymann

Securitization of Islam: A Vicious Circle 
Kathrin Lenz-Raymann (lic. phil.) works in the field of political consulting in Zurich, Switzerland. Her research interests include social and human security, counter-terrorism policies and human rights. 
KATHRIN LENZ-RAYMANN

\section{Securitization of Islam: A Vicious Circle}

Counter-Terrorism and Freedom of Religion in Central Asia

[transcript] 
This thesis was accepted as a doctoral dissertation by the Faculty of Arts of the University of Zurich in the spring semester 2014 on the recommendation of Prof. Dr. Albert A. Stahel, Prof. Dr. Kurt Imhof and Prof. Dr. Ueli Mäder.

This project was funded by the Swiss National Science Foundation (SNSF).

\section{FNSNF}

FONDS NATIONAL SUISSE

SCHWEIZERISCHER NATIONALFONDS

FONDO NAZIONALE SVIZZERO

SWISS National SCIENCE Foundation

\section{(9) $(1 \Theta \Theta$}

This work is licensed under the Creative Commons Attribution-NonCommercial-NoDerivs 4.0 (BY-NC-ND) which means that the text may be used for noncommercial purposes, provided credit is given to the author. For details go to http://creativecommons.org/licenses/by-nc-nd/4.o/.

To create an adaptation, translation, or derivative of the original work and for commercial use, further permission is required and can be obtained by contacting rights@transcript-verlag.de

\section{(C) 2014 transcript Verlag, Bielefeld}

\section{Bibliographic information published by the Deutsche Nationalbibliothek}

The Deutsche Nationalbibliothek lists this publication in the Deutsche Nationalbibliografie; detailed bibliographic data are available in the Internet at http://dnb.d-nb.de

All photographs and cover illustration: Lisa Harand

Cover layout: Kordula Röckenhaus, Bielefeld

Printed by Majuskel Medienproduktion GmbH, Wetzlar

Print-ISBN 978-3-8376-2904-0

PDF-ISBN 978-3-8394-2904-4 


\section{Content}

Thanks | 13

Summary | 15

1. Introduction | 17

1.1. Research Interest | 17

1.2. Theoretical Background 127

1.3. Methods I 30

1.4. Databases, Country Reports and Country Profiles I 38

\section{PART I REVIVAL OF ISLAM:}

\section{CASE StUdies OF ISLAMIC GROUPS}

2. Features of Central Asian Folk Islam | 45

2.1. General Remarks on Islam | 45

2.2. Sunni Hanafi Madhab $\mid 49$

2.3. $\quad$ Sufism $\mid 54$

2.4. Folk Islam: Saints Culture and Mazar Worshipping I 61

3. Salafi Islam: Social Transformation and

Political Islam I 69

3.1. Catchwords, Misconceptions and Important Terms 170

3.2. Political Islam and Salafism $\mid 76$

3.3. Jihadists: Armed Warriors for the Caliphate 183

3.4. Islamists: Political Parties 189

3.5. Modernists and Neo-Fundamentalists:

Social Transformation 197

4. Typology of Islamic Groups । 109

4.1. Folk-Islamic Groups I 109

4.2. Non-Traditional Islamic Groups $\mid 110$ 


\section{PART II POLITICS AND ISLAM: Case Studies of Political Regimes}

5. History of Politics and Islam in Central Asia I 117

5.1. Early Empires and Islamization of Central Asia I 117

5.2. The Communist State and Islam in Central Asia I 129

6. General Comparison of Contemporary Regimes I 139

6.1. Demographic Situation I 142

6.2. Socio-economic Situation 1147

6.3. Political System and Government Bodies I 158

\section{Comparison of the Contemporary Role of Religion} in Politics | 177

7.1. Freedom of Religion and The Concept of Recognition | 178

7.2. Secularity in the Constitution । 179

7.3. Content of Religious Laws । 185

7.4. Institutions Involved with Religion | 196

7.5. Procedures Concerning Religion $\mid 202$

8. Comparison of Law Enforcement I 209

8.1. Security Strategies and Counter-Terrorism Laws I 210

8.2. Security Forces 1214

8.3. International Cooperation in the Security Sector I 221

8.4. Comparison of the Judiciary: Trials and Torture 1227

9. Typology of Religious and Counter-Terrorism Politics 1233

9.1. Typology of State Regulation of Folk Islam | 233

9.2. Typology of State Regulation of

Non-Traditional Groups 1236 


\section{Part III Securitization: THEORY AND SIMULATION MODEL}

10. Securitization Theory:

Legitimacy in Security Politics | 243

10.1. Legitimacy in Securitization Theory I 243

10.2. Vocabulary and Units of Analysis 1246

10.3. Securitization of Islam in Central Asia 1252

11. Model Description | 257

11.1. Overview and ODD-Protocol | 257

11.2. Simulation Setup I 264

11.3. Simulation Results: Revival of Islam | 271

11.4. Threatened Reference Objects I 273

11.5. Securitizing Moves $\mid 276$

12. Model Verification and Validation 1279

12.1. Sensitivity Analysis 1279

12.2. Verification: Mutual Reinforcement of Securitization I 280

12.3. Validation: Simulation Results and Empirical Data $\mid 282$

13. Conclusions $\mid 289$

13.1. Conclusions from Computer Simulation I 289

13.2. General Concluding Remarks I 290

Literature | 293

\section{Appendix}

Appendix A: Official Documents and Websites I319

Appendix B: NetLogo Code for Simulation I 321

Appendix C: Initial Values and Parameters for Simulation I 324 


\section{LIST OF TABLES}

Table 1: Muslim Population in Central Asia: Sunnis and Shiites I 50

Table 2: Typology of Non-Traditional Islamic Groups $\mid 112$

Table 3: Demographic Benchmarks I 142

Table 4: Ethnic Composition of Central Asian Societies I 144

Table 5: Religious Composition: Muslims and Christians I 145

Table 6: Economic Benchmarks | 147

Table 7: Poverty Benchmarks | 151

Table 8: Numbers of Migrant Workers Abroad I 153

Table 9: International Trading Partners | 154

Table 10: Infrastructural Benchmarks I 156

Table 11: Human Development Index | 157

Table 12: Political Systems and Presidents I 161

Table 13: Structure and Composition of Parliaments | 165

Table 14: Freedom and Democracy Indices I 169

Table 15: Religious Committees I 196

Table 16: Muftiates and Muftis 1202

Table 17: Paramilitary Resources $\mid 217$

Table 18: Military Resources I 221

Table 19: Political Terror Scale I 230

Table 20: Legal Status of Salafi Groups in Central Asia I 236

Table 21: Religious Persecution Index 1239

Table 22: Detainees on Religious Grounds 1240

Table 23: Securitization Theory in the Central Asian Context 1252

Table 24: Conflict Assumptions for Vicious Circle Hypothesis I 254

Table 25: Securitization in the Simulation 1258

Table 26: ODD-Protocol | 259

Table 27: Application of Data for Simulation Model I 267

Table 28: Calculation of Context-Legitimacy 1268

Table 29: Initial Values for Simulation 1268

Table 30: Interactions of Agents | 269

Table 31: Context-Legitimacy (Simulation Parameter) 1272

Table 32: Capacities of Security Forces (Simulation Parameter) I 273

Table 33: PTS (Simulation Parameter) 1277

Table 34: Validation of Terrorist Attacks 1283

Table 35: Validation of Timing of Securitizaton by State Actors I 284 
Table 36: Validation of Constraints on Religious Freedom I 286

Table 37: Initial Values and Parameters for Simulation I 324 


\section{LIST OF FIGURES}

Figure 1: Numbers of Suicide Attacks in Central Asia I 20

Figure 2: Repression-radicalization Hypothesis 123

Figure 3: Vicious-circle Hypothesis I 26

Figure 4: Percentages of Muslims Identifying with a Sufi Order I 63

Figure 5: Percentage of Muslims Supporting Folk Islam I 67

Figure 6: Quran Reading by Central Asian Muslims 178

Figure 7: Approval for Terrorist Attacks Compared to Support for Sharia 184

Figure 8: Attitudes towards Political Islam among Central Asian Muslims 189

Figure 9: Relationship between Religion and Modernity 198

Figure 10: Preference for Democracy or a Powerful Leader I 163

Figure 11: Frequency of Prayers and Visitation of Religious Services I 234

Figure 12: Perception of Religious Policies by Central Asian Muslims 1234

Figure 13: Different Religious Groups Compete for Influence I 271

Figure 14: Unofficial Islam Supercedes Official Islam I 272

Figure 15: Arbitrary Arrests Lead to Protest 1274

Figure 16: Clouds of Protestors Gather I 275

Figure 17: Political Islam's Share of Unofficial Islam I 275

Figure 18: Radicalized Detainees Released asJjihadists I 276

Figure 20: No Detentions and No Protests | 281

Figure 21: Detentions and Protests 1281

Figure 22: Protestors, Jihadists and Casualties 1282

Figure 23: Simulation Results $\mid 289$ 


\section{LIST OF IMAGES}

Image 1: Mosque at Baytik Baatir Mazar I 65

Image 2: Gravestone of Baytik Baatir's Friend I 65

Image 3: Shayk at Baytik Baatir Mazar I 66

Image 4: Meeting at the IRPT Headquarter in Dushanbe 195

Image 5: Kabiri, President of the IRPT 196

Image 6: Manas University in Bishkek 199

Image 7: Madrasa supported by Gülen Movement in Bishkek | 101

Image 8: Gülen Radio Maral in Bishkek $\mid 102$

Image 9: Kyrgyz Member of Tablighi Jama' at I 107

Image 10: Private Religious Class in Bishkek 192

Image 11: Kazakh Muftiate in Almaty $\mid 198$ 



\section{Thanks}

This study is my doctoral thesis and was financed by the Swiss National Science Foundation (SNF). I am glad for having had this opportunity to work and do research in my special field of interest. First of all, my thanks go to my doctoral committee, consisting of Prof. Dr. Albert A. Stahel (Institute for Strategic Studies, Wädenswil), Prof. Dr. Kurt Imhof (University of Zurich) and Prof. Dr. Ueli Mäder (University of Basel). In particular, Albert Stahel strengthened my critical mind concerning world politics and the strategic decision-making of nation states. His faith in my scientific endeavours gave me the self-confidence to keep going with my work.

My simulation model profited from the long-time simulation experience and advice of Armando Geller (co-founder of Scensei, and affiliated with the School of Conflict Analysis and Resolution at George Mason University in Washington) and Lukas Schmid (head of the Institute for Innovation, Design und Engineering at the University of Applied Sciences of St. Gallen). Their critique enabled me to improve the model and made me realise that a lot would still have to be done to bring it up to date.

Many people enriched this study by giving me formal or informal interviews in Central Asia. I cannot name all of them because some could face difficulties with their restrictive governments. I am very thankful for their hospitality and openness to discuss with me their religious and political worldviews.

My Kyrgyz friends in Switzerland enabled me to come into contact with many people in the field and were always open to discuss the topic of my research with me. Without them this study would not have become as vivid, well-researched and detailed as it has. They helped me with their knowledge of local languages, by sharing their own research and life expe- 
riences with me, and by contacting their relatives and friends in the region. Aijamal Huonker was also employed by SNF in the project to do research in local online newspapers as well as on official websites, and also helped me to transcribe some interviews. Baktygul Karimova was especially helpful by advising me on how to do research in the field and by introducing me to many people in the field.

Another special thanks I owe Lisa Harand. She enabled me to undertake a research trip to Central Asia by looking after my daughter during my interviews there. The wonderful pictures she took enrich this study with insights that words cannot capture. After a common vernissage we copublished a "by-product" of my dissertation - the photobook "ReIslamisierung in Zentralasien". Our collaboration showed me that scientific research is even more valuable if it is illustrated in a way accessible to the broader public.

My former English teacher, Lee Mackenzie, reviewed my texts carefully and I am indebted to him not only for grammar corrections but also for many comments on style. Except from myself, no-one read my texts as carefully as he did, and I think no-one will do so in the future. Apart from his professional help, I am very happy that he was on my side during the whole process of the development of this study.

To take a broad view, without my employment at econcept AG, this study would have been much more difficult to accomplish. By giving me very good and flexible working conditions, Barbara Haering enabled me to work, complete my doctorate and also give birth and raise two wonderful girls all at the same time.

Last but not least, I want to thank my friends and, most of all, my husband and family members who have been patient enough to enable me to fulfil this work which has become a matter that is close to my heart. 


\section{Summary}

The main concern of my study is to understand the contemporary conflicts regarding Islam in the Central Asian states of Kazakhstan, Kyrgyzstan, Tajikistan and Uzbekistan. Today a revival of Islam can be observed, which began in the last years of the Soviet Union. Since the late 1990s Central Asian governments have feared Islamic terrorism and have taken diverse measures against its spread. Despite this, as I show, apart from fundamentalist movements, modernist groups and folk Islam are also gaining ground in Central Asia. By way of an explanation, my vicious-circle hypothesis demonstrates how state repression against such movements might be having a counter-intended effect on the radicalization of Muslims in the region.

The revival of Islam in Central Asia cannot be analyzed without understanding the local forms of Islam prevalent in the region. Part I of the study highlights the most important aspects of Central Asian Islam such as the prevalence of the Sunni Hanafi School of law and the adaptation of local customs; the combination with pre-Islamic rituals, and the influence of Sufism. Following this I present an overview of the different definitions of political Islam and the history of Salafism before introducing the most influential Salafi groups in the region. Not only do I focus on radical political groups in my analysis but also on apolitical groups and religious movements aiming at the mere social transformation of the society. Indeed I also regard these as an essential part of my analysis since they often have more members than political groups and are similarly prone to state repression. This part concludes with a typology of actors contributing to the revival of Isalm.

In part II I focus on the relationship between politics and religion during the last centuries. Knowledge of tsarist and communist religious po- 
licies is important for an understanding of the politics of the contemporary Central Asian states in the domains of religion, security and jurisprudence. I start my comparative study by addressing the issue of how Central Asian states are currently dealing with Islam: I analyze the status of religion in their respective constitutions, the content of religious laws, the institutions which are involved with religion and some important state-controlled procedures concerning religion such as hajj and the registration-process for religious communities. I furthermore compare these countries' security strategies and counter-terrorism laws, the capacities of their secret police (GKNB), of their internal forces (MVD) and their military and give an overview of their international security cooperation. Against this background, I finally elaborate an actor-typology of the Central Asian states' restrictions towards Islamic groups.

In part III securitization theory provides us with a useful theoretical framework to analyze my hypothesis with an agent-based computer simulation. As I reveal, many observers of Central Asian government policies suggest that state repression towards Islamic groups leads to the radicalization of individuals but they do not explain how this mechanism has come about. I here use a computer simulation model to test my hypothesis and the assumed mechanisms. Finally, I present my simulation model of the conflict in Central Asia and draw some conclusions from the simulation outcomes. 


\section{Introduction}

\subsection{RESEARCH INTEREST}

Today western countries fear international terrorism and Islamic fundamentalism. As Richard Clarke made clear after 9/11, the international terror network of jihadists will be the biggest danger to the US national security in the near future and will probably also need to be combated in the following generation (Clarke 2005: 11). In addition to western nation-states, the United Nations Security Council also declared terrorism a major threat to international security. After 9/11 the following Security Council Resolution was penned on September 28 2001: "[...] the Security Council [is] deeply concerned by the increase, in various regions of the world, of acts of terrorism motivated by intolerance or extremism" (UNO 2001: 1). Whereas western governments have subsequently used the (legitimate) grounds of state security to justify their 'War on Terror', they have at the same time, "persuaded their citizens to accept less progressive and rigorous norms, easing the job of law enforcement at the cost of individual human rights" (Kamalova 2007: 1). This is even truer for Central Asian governments who are used to governing in an environment where respect for human rights does not yet have such a long political tradition as in Europe and the US. I concentrate here on the comparison of the former Soviet Republics of Kazakhstan, Kyrgyzstan, Tajikistan and Uzbekistan. (As Turkmenistan is a too special case because the repression and state-control are very extreme and the country is totally closed to any international observers and scientific research, this case is excluded from the study.) Despite criticism from human rights organizations, western powers like the US, France and Germany as well as western collective treaty organizations such as NATO collaborate along with Russia and SCO - with these authoritarian Central Asian re- 
gimes to 'fight terrorism'. These human rights organizations state that the international discourse on Islamic terrorism justifies human rights violations and the suppression of the already very weak opposition in the Central Asian countries. Indeed, Khalid explains that by taking part in the 'War on Terror' Central Asian countries can expand their power "by tying all domestic opposition to 'international terrorism', even when no links actually exist" (Khalid 2007: 169). Kamalova exemplifies this with the case of Uzbekistan which went furthest in this regard (Kamalova 2007).

The Central Asian countries differ in terms of the strength of their political regimes; the extent to which their security forces use repressive means, and also in terms of their respective cultures and level of religiosity. However, despite these differences, my case study shows that at least with regards to the development of the religious reality and the handling of religious groups all Central Asian states share some common features.

Social developments:

- A 'revival of Islam' is underway in Central Asia. This 'revival of Islam' is ideologically multi-faceted: not only are neo-fundamentalist movements becoming more popular but modernist Islamic groups are also gaining more members. In addition, folk Islam is being practiced on a more regular basis.

- On the one hand there are devout religious Muslims without any social or political agenda while on the other there are armed Islamic groups aiming to establish an Islamic state.

- Among those who are working towards an Islamic society are groups which proselytize peacefully and others who execute terrorist acts which lead to deaths and casualties.

Government response:

- The Central Asian governments have established their own interpretation of 'traditional Islam' as the legal, 'official' Islam.

- Central Asian governments lump together all foreign Islamic movements as 'extremist' and 'terrorist'.

- The Central Asian governments restrict the freedom of religion of their citizens by counter-terrorism measures. 


\subsubsection{Research Question}

Comparing the extreme examples concerning the threat of Islamist terrorism I can observe the following differences between the Central Asian states:

- Since the early 2000s seven suicide attacks have taken place in Uzbekistan (see Figure 1). Furthermore, this country has the highest numbers of detainees on religious grounds: the total figure is estimated to be several thousands (see Table 21). According to the Human Rights Defenders of Uzbekistan in 2012 alone 250 Muslims were detained on religious grounds (see US State Department 2013).

- In Kyrgyzstan no terrorist attacks have occurred so far although it is the country with the highest percentage of Muslims (10\% of the population) that regard attacks against civilians as at least sometimes justified (see Figure 7) in order to defend Islam (Uzbekistan is the country with the lowest percentage of $0 \%$ ). Furthermore, an astonishingly high percentage of over $30 \%$ of Kyrgyzstanis would welcome the introduction of Sharia as the law of the land (see Figure 7 as well; there is no data available on this question for Uzbekistan). Despite these facts, it is the Central Asian country with the smallest numbers of detainees on religious grounds (approximately 50 people).

Another difference between the two countries is that Uzbekistan has the largest proportion of Muslims that do not feel free to practice religion while Kyrgyzstan is the Central Asian country where Muslims feel most free to practice their religion (see Figure 12). 
Figure 1: Numbers of Suicide Attacks in Central Asia

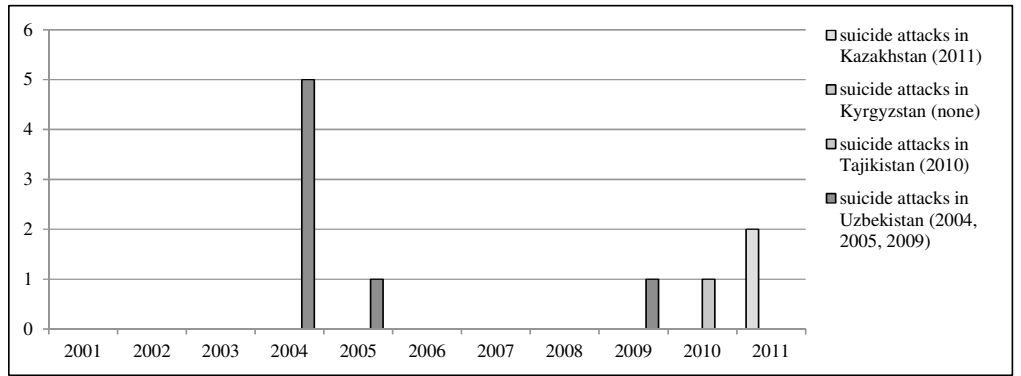

Source: GTD (2013)

It is furthermore interesting to note that in each country where suicide attacks occurred this invariably happened after the introduction of a restrictive religious law: such a law was introduced in Uzbekistan in 1998, in Tajikistan in 2009 and in Kazakhstan in 2011. (In Kyrgyzstan a new religious law was introduced in 2009 and amended in 2012.)

Against this background I pose the following research questions:

- Why does the revival of Islam lead to different degrees of radicalization of Muslims in Kazakhstan, Kyrgyzstan, Tajikistan and Uzbekistan?

- Does a vicious circle between counter-terrorism measures and radicalization of Muslims exist in Central Asia? Why could this be the case?

I will now introduce some important terms and then elaborate on the concepts of repression and radicalization before turning to the broader theoretical background of radical Islam and security issues. 


\subsubsection{Definitions}

Before I start to theorize about this topic I must clarify some terms.

- State actors: if I speak of a state actor I have the Central Asian governments as well as their ministries, institutions and security forces in mind. The term state actor refers to the collective of individuals working in these state institutions.

- Non-state actors: if I speak of non-state actors I am referring to Muslim groups which either have or do not have a political agenda but share the same goals or sentiments of Islam. The term non-state actor refers to the collective group and not to an individual member of the group.

- State violence/ Repression: the terms state violence and repression are used interchangeably and refer to "the action [of a state actor] of subduing someone or something by force" (Oxford dictionary ). When I speak of state-violence of repression without further specification I refer to violence aimed at members of Islamic groups. Repressive means used by a state can be legitimate or illegitimate as well as legal or illegal. Whereas the legality of repressive means depends on the state's laws, the legitimacy of repressive means is not only a question of laws and rules but also of the "ability to be defended with logic or justification; validity" (Oxford dictionary) (see definition of legitimacy).

- Radicalization: I distinguish between ideological and methodological radicalization. A person who is ideologically radicalized becomes an advocate of "thorough or complete political or social reform; a member of a political party or part of a party pursuing such aims" (Oxford dictionary ). A person who is methodologically radicalized becomes militant, which means that he favours "confrontational or violent methods in support of a political or social cause" (Oxford dictionary ).

- Non-state violence/ Militancy: the terms non-state violence and militancy are used interchangeably and refer to violent means used by nonstate actors. When I speak of non-state violence or militancy I mean property damage or harm caused to people by citizens belonging to an Islamic group. Non-state violence can have a terrorist character if it is directed against civilians or a guerrilla-like character if it is directed against security forces, police or the government. It is always illegal but 
can be regarded as legitimate or illegitimate (see definition of legitimacy).

- Legitimacy: legitimacy is important in my study in two different ways. First, there is the question of whether state and non-state violence is legitimate in a normative way. The use of repressive means by a state or militant means by a non-state actor is legitimate if it is morally or religiously justifiable. (The Stanford Encyclopedia of Philosophy calls this a narrow normative definition of legitimacy. )

The second issue concerns the fundamental question of the legitimacy of the Central Asian states and governments. In this regard Weber's distinction of three different sources of legitimacy for rule is important for what the Stanford Encyclopedia of Philosophy calls the "descriptive definition of legitimacy". Crucial in this respect is the citizen's belief in the legitimacy of a political regime: "the basis of every system of authority, and correspondingly of every kind of willingness to obey, is a belief, a belief by virtue of which persons exercising authority are lent prestige" (Weber 1964: 382). In the Central Asian context Weber's different (rational-legal, traditional and charismatic) sources of legitimacy for a government or ruler can be understood as: the ability to maintain political stability, provide economic development or mere habituation to clan politics or Soviet style of rule (I will go into further details of such consideration in section 6.3.1).

- Security: traditional concepts of security refer to national security, which means the absence of military threats from inside and outside of a country. Whereas this puts the sovereign nation state at the heart of security policies, the term human security refers to the security of the individual. This definition is relevant as "far more people have been killed by their own governments than by foreign armies during the last 100 years" (HSRP). At any rate, there is a degree of correlation between issues of national and human security. The Human Security Report Project (HSRP) defines human security as "the combination of threats associated with war, genocide, and the displacement of populations" which means "at a minimum, $[\ldots]$ freedom from violence and from the fear of violence" (HSRP). In a broader sense, "hunger, disease, pollution, affronts to human dignity, threats to livelihoods, and other harms" are also regarded as human security issues (HSRP). Under this broad 
definition the protection and provision of social and economic human rights is essential.

I will come back to these concepts of security when discussing the results of the simulation. I will now analyze in detail the arguments of those who criticize the collaboration of western powers with authoritarian Central Asian regimes because of the latters' response to the 'revival of Islam' and thereby elaborate my hypothesis.

\subsubsection{Repression-Radicalization Hypothesis}

When arguing that western powers should not collaborate with authoritarian regimes who spurn basic human rights, human rights defenders and also scientists often refer to what I will call here the repression-radicalization hypothesis. This hypothesis implies that individuals who experience the suppression of their human right to freedom of religion are radicalized. Not only practitioners and field workers but also independent observers mention this hypothesis and I therefore scrutinize its implications in more detail in this study.

Repression-radicalization hypothesis:

In the long run, strong state repression against Islamic groups leads to the radicalization of Muslims in Central Asia.

Figure 2: Repression-radicalization Hypothesis

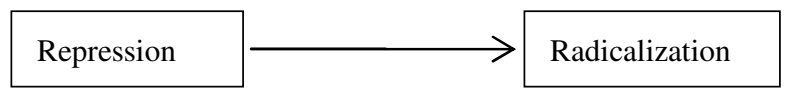

Expert interviews in the region revealed that it is more realistic to act on the assumption of the radicalization of individuals rather than on the assumption of the radicalization of entire groups (interview with member of Politico-Military Unit OSCE in Bishkek). Let us elaborate on the aforementioned mechanism with some examples of statements. First of all, the presentation of religious or political issues as a security problem by governments indi- 
cates that the state fears devout Muslims because of their social influence. As I can see from the following examples, many observers concentrate on the case of Hizb ut-Tharir. This group is discussed especially controversly as it is a political party that aims at establishing a caliphate across the contemporary nation-states but despite using only non-violent means it is illegal in all Central Asian countries (see also Karagiannis 2010: 72).

Indiscriminate repression of devout Muslims begs the question: how many alleged extremists are merely devout peaceful Muslims rather than terrorists? How many of them feel aggrieved because of the human rights violations they experience and subsequently become extremists only after being arbitrarily detained? The following statement by Halbach exemplifies this view with reference to Uzbekistan:

"For a long time now, the undifferentiated approach taken towards alleged or actual religious extremists in Uzbekistan has led us to question whether power, with its violent actions, actually fosters radicalization tendencies instead of preventing them" (Halbach 2010a: 95, translated by the author).

Halbach's comments are echoed by Karagiannis, who observes that repressive means against fundamentalist movements can have a counter-intended effect. He gives the example of the non-violent group Hizb ut-Tahrir, which has only attracted greater publicity as a result of its criminalization: ${ }^{1}$

"[...] the adoption of repressive and punitive measures to combat a radical, but nonviolent, Islamic group has only increased the appeal of Hizb ut-Tahrir among Central Asian populations" (Karagiannis 2010: 72).

By detaining members of banned groups, the government tries to suppress the group, but this does not always have the desired effect. Kamuluddin's argument is in a similar vein. He explains the counter-intended effect of developing martyrs" stories by means of detentions:

1 Criminalize means: "turn (an activity) into a criminal offence by making it illegal: turn (someone) into a criminal by making their activities illegal" (Oxford dictionary: http://www.oxforddictionaries.com/definition/english/criminalize). 
"by imprisoning and persecuting the members of the party, the authorities are, in effect, providing substantial assistance to the Hizb ut-Tahrir, which, as a result, enjoys the aura of martyrdom" (Kamuluddin 2005).

My case studies show that the registration of religious groups is one of the main instruments for controlling the religious landscape in the Central Asian countries. This allows for the criminalization of groups which do not pass the registration process and therefore are per se illegal. Members do not even have to be accused of making any attempt to topple or attack the regime. Persons therefore can be arrested and detained only on grounds of their mental attitude (as members of an illegal group) instead of their behaviour (interview with Sultangaliyeva, former Director of the Kazakhstan Institute for Strategic Studies). As Vitaly Ponomarev, Head of the Central Asia department of the Russian Memorial Human Rights Center makes clear, until 1998 the penal code was hardly ever applied to religious extremists except for convictions regarding possession of illegal drugs and weapons (which were planted during their arrest) (interview with Ponomarev). From 1998 to 2001, however, the majority of Islamists were convicted of acting against the constitution while more recently articles against the distribution of material threatening public security (Art. 244-1) and membership of a banned group (244-2) have been applied (interview with Ponomarev).

If I focus on the banned groups and what has happened to their members, one important point has to be considered: detained persons are likely to become radicalized in prison. Several studies analyze this phenomenon such as Fighel's paper entitled 'The Radicalization Process in Prisons' (Fighel 2007). Although this mainly concentrated on the US and Europe, the following is true globally:

“The prison's isolated environment, ability to create a 'captive audience' atmosphere, its absence of day-to-day distractions, and its large population of disaffected young men, makes it an excellent breeding ground for radicalization" (Fighel 2007: 1).

The International Crisis Group briefing 'Central Asia: Islamists in Prison' concentrates on Kyrgyzstan and Kazakhstan specifically (ICG 2009). Here the authors come to the conclusion that the number and political importance 
of Islamists in Kyrgyz and Kazakh prisons is growing (ICG 2009: 1). Furthermore, poor living conditions, prevailing corruption and abuse of office in the prisons are severe grounds for concern (ICG 2009: 13). Although I will not go into further details of how the radicalization in prisons takes place I will use it as the main indicator to simulate radicalization through repression. The fact that I have estimated numbers of detainees on religious grounds for all four countries also speaks for this approach.

When discussing the counter-intended effects of repression we should first of all keep in mind, though, that repression itself is considered to be the solution to the existence of radical and terrorist groups. The very fact that more radicalization leads to more repression is also understandable because the state can more easily gain legitimacy for the repression of Islamic groups when these groups become more prominent in society.

\subsubsection{Vicious-Circle Hypothesis}

It is important to note that the state suppression of Islamists results in more than just a counter-intended effect. First of all, repression prevents groups from acting overtly, diminishes their proselytizing efforts, reduces their resources and awes their members. For these reasons I will not dwell upon the repression-radicalization hypothesis but develop it further and talk of a vicious circle of repression and radicalization.

Vicious-circle hypothesis:

State repression against Islamic groups and radical political Islam mutually reinforce each other in Central Asia

Figure 3: Vicious-circle Hypothesis

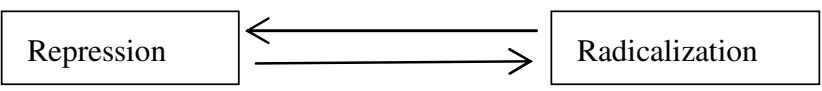

I now give an overview of theories used to understand the revival of Islam in Central Asia and then introduce the methods and data applied in this study for analysing and testing the vicious-circle hypothesis. 


\subsection{Theoretical Background}

In order to explain the development of political Islam as an opposition power, authors refer to theories such as functionalism, resourcemobilization theory, political process theory or frame theory. However, most of the experts on Central Asian political Islam refer to these theories only in a delimiting way (see for example Karagiannis 2010). Furthermore, in Naumkin's view these theories, as well as theories of political deprivation and economic or psychological explanations, are not useful for an analysis of radical Islam in general and radical Islam in Central Asia specifically. He therefore suggests refraining from using all theoretical approaches to the subject. Hafez also criticizes socio-economic and psychological approaches as well as political process theory; however, he does turn to social movement theory for an explanation of violent Islamism.

I am not interested in the general reasons for why radical Islamism has come about and therefore do not want to judge the usefulness of theories for an analysis of political Islam. Instead I am interested very specifically in the above mentioned interplay of governmental politics and radicalizing tendencies in political Islam. I therefore now provide an overview of theoretical approaches dealing with legitimacy and security politics as well as with constructivism in general. Only in chapter 10 will I elaborate on securitization theory in more detail.

Mainstream approaches in International Relations such as Realism or Liberalism explain insecurity and security politics in terms of objective threats (see Balzacq 2011: xii) which are therefore not useful for analysing the vicious circle of repression and radicalization: They refer to material incentives for explaining participation in armed groups. Therefore, rational explanations disregard legitimacy, which is a very important factor for maintaining or escalating a conflict. Its importance as a precondition for collective action is without controversy in sociology but underestimated in International Relations. Whereas the 'just war' theory investigates under which circumstances war is justifiable, it is more concerned with morality than with its impact on collective behaviour. What I do, however, is not to conduct a normative analysis but to analyze the impact 'described' legitimacy has on the further participation of state and non-state actors in the conflict. 
Sociological approaches are useful in this regard: non-material incentives such as a leader's charisma, group ideology or the satisfaction of pursuing justice or vengeance are issues of sociological conflict research (Blattman and Miguel 2010: 15). Schlichte (2009) acts on the assumption of a political sociological viewpoint and identifies legitimacy as a key variable in explaining the success and failure of non-state armed groups. He states that "violence can legitimate power, but it can also have de-legitimizing effects" (Schlichte 2009: 20). Conflict parties must overcome what he calls the 'shadow of violence' (Schlichte 2009: 14) to be collectively capable of acting. "It is the de-legitimizing and legitimizing effects of violence that are at the core of the dynamics which decide about an armed group's fate" (Schlichte 2009: 17). Without legitimacy the mobilization for collective violent action is not feasible.

Furthermore, practitioners acknowledge the importance of 'winning the hearts and minds' of the population in a conflict. NATO for example emphasized the importance of legitimacy as a tool to attain strategic goals in the tactical directive for ISAF soldiers in Afghanistan:

"We will not win based on the number of Taliban we kill, but instead on our ability to separate insurgents from the center of gravity - the people. That means we must [...] operate in a manner which will win their support" (McCrystal 2009: 1).

This was scrutinized in studies on terrorism and counter-terrorism policies. Empirical research on the impact of legitimacy on conflict development has been carried out by Wenger and Zimmermann (2007), who examine the connection between legitimacy and efficiency in the counter-terrorism policies of western states. They find that "combating terrorism is no short-term endeavour. Thus, in the long term, legitimacy matters, both in terms of our self-perception and in terms of the political perceptions of the people affected by global terrorist forces" (Wenger \& Zimmermann 2007: 13).

With this I come back to the intended and counter-intended effects of repression and to the vicious circle of violence. If we are looking for a theoretical framework for further developing the vicious-circle hypothesis, we should look no further than constructivism for gaining an understanding of the role of legitimacy, as well as of the counter-intended and mutually reinforcing effects. 
The constructivist idea implies that social relations and structures consist of three elements:

- Shared knowledge

- Material resources

- Practices

Shared knowledge is decisive when actors cooperate or conflict (Wendt 1995: 73). In a security dilemma, actors mistrust each other and therefore are prone to use violent means in order to enforce their claims. In a security community, on the other hand, actors share the same knowledge and conflicts can be reconciled. Wendt explains that material resources per se do not promote or prevent conflicts. Instead: "[...] Amity or enmity is a function of shared understandings" (Wendt 1995: 73). The US, for example, is far more concerned by North Korea's possession of nuclear weapons than by Israel's. Furthermore, a conflict exists only as long as corresponding practice is executed:

"Social structure exists only in process. The Cold War was a structure of shared knowledge that governed great power relations for forty years, but once they stopped acting on this basis, it was 'over'" (Wendt 1995: 73).

Contrary to rational choice approaches, the constructivist approach assumes that interactions between actors have an influence on their interests and identities. Therefore it is useful to analyze conflicts in general and the vicious circle of repression and radicalization specifically using this approach. It is important to my study that the actors' perceptions are not mere inventions but are galvanised by real occurrences. However, these occurrences are interpreted and remembered by the actors involved in different ways. In a viable conflict system, the actions of one actor legitimize the actions of his opponent because the actions of both are mutually dependent. ${ }^{2}$

2 "Viability means that knowledge or other constructions have to prove themselves to be useful and viable in a certain context of use - they have to be appropriate and enable an individual to act and survive in a particular context. This does not mean that constructions have to be true or have to contain accurate de- 
In our case, this means that if a suicide attack takes place in a market place, killing civilians, this reinforces their opponents' perception of Islamists as inhuman, irrational lunatics. Similarly, if the US justify the loss of civilians in their 'War on Terror' as 'collateral damage', this reinforces their opponents' perception that the United States' interest in democracy and human rights is duplicitous. This is even easier to prove in case of the Central Asian states which are governed by former Communist party officials who lack any democratic legitimacy.

\subsection{Methods}

In addition to a computer simulation, which I use as an analytical method in my study, qualitative research methods such as content analysis and interviews are used. In this chapter I will provide details regarding my qualitative research followed by an overview of agent-based modelling in the social sciences.

\subsubsection{Qualitative Research}

Laws on religion and terrorism published by the Central Asian governments as well as interviews and publications of religious groups constitute important primary sources for the analysis. The official documents and websites used for analysing the Central Asian governments' position towards religion are listed in Appendix A.

Furthermore, it was regarded as essential to include contemporary events in the study and therefore online-news portals reporting in Russian (for example Centerasia www.centrasia.ru and Radio Azattyk http:// rus.azattyk.org) were reviewed on a regular basis (these provide not only more diverse information about the region than English online-news portals such as Tengri News or EurasiaNet but also a greater amount).

I reviewed secondary analyses on Islam in Central Asia in recent centuries and more specifically in the last few decades in order to gain an overview of the history of its relation to politics. In addition, I reviewed litera-

pictions of reality - neither of these can be proven because they cannot be directly compared to the original" (Flick 2008: 163f). 
ture on Islamic terrorism in general and radical groups active in the region in particular. Studies on 'everyday Islam' completed this stage of my analysis and raised questions concerning the acceptance of groups adhering to a scriptural interpretation of Islam in the broader Central Asian population.

I directly observed the prevailing mood concerning the relationship of religion and politics in the Central Asian countries during a research trip to Kazakhstan, Kyrgyzstan and Tajikistan from February to March 2013. In addition to formal interviews with experts and devout Muslims in the field (listed in Appendix B), several informal talks with ordinary people and observations took place in Almaty, Bishkek and Dushanbe as well as in nearby places of these capitals. In Bishkek I was able to visit a madrasa and a mosque of the Gülen movement as well as a private primary school of the same movement. Outside of the city I conducted observatory research at the Mazar of Baityk Baatyr and the worshipping that took place there. I furthermore could participate in a religious meeting of an unofficial religious class of women in Bishkek that lastet for several hours. In Almaty, I paid a visit to the official city mosque and talked to women working there. In Dushanbe I took a trip to the Ismaili Centre, Haji Yakoub mosque and two small neighbourhood-mosques. Unfortunately I could not realize a planned research excursion to Uzbekistan because of difficulties obtaining a visa.

Finally, I applied the information from the primary sources, secondary analyses and fieldwork in the case studies of the Islamic groups and governments and elaborated a computer simulation model to further develop and scrutinize my assumptions. Because the analytical method of agentbased simulations is not yet well known in social sciences, I will presently give a short overview of simulation methods. Following this, one of the best known agent-based conflict models will be presented. Only in chapter 11 I will expose how I deal with the main elements of agent-based simulation for analysing the religious conflict of state and non-state actors in Central Asia.

\subsubsection{Simulation as an Analytical Method in Social Sciences}

Computer simulations are still not very commonly used in social sciences even though they are very useful for analyzing dynamic, non-linear and emergent processes: the scientist builds a model of a real-world phenome- 
non as a computer-program and runs it to find out if the assumed mechanisms work in the expected way. Although it is possible to conduct statistical analysis to test, for example, exponential growth with nonlinear regression analysis, "the only generally effective way of exploring non-linear behaviour is to simulate it by building a model and then running the simulation" (Gilbert and Troitzsch 2005: 10). A computer simulation model is not very different from other models used in social sciences: "Computational models are formulated as computer programs in which there are some inputs (somewhat similar to independent variables) and some outputs (similar to dependent variables)" (Gilbert 2009: 2). However, there is one big advantage - its usefulness for analysing dynamic and nonlinear developments. Other advantages (for my study) of simulations in general and agent-based models (ABM) in particular are:

- Bounded rationality: information is local - agents make up their mind based on their own experiences and on the messages they receive from other agents. Therefore, they do not have all the necessary information to be able to make a rational decision. Secondly, their decisions are influenced by their subjective condition (i.e. socio-demographic precondition), personal memories and experiences, and group propaganda. ${ }^{3}$

- Heterogeneity of agents: individuals support one or the other side in the conflict. Even if they support the same group, they are heterogeneous with regard to their propensity for violence, their experience and to the legitimacy they ascribe to the groups.

- Interactions between agents: agents can react to each other and to their environment.

- Linking of individual behaviour with macro-outcome: the collective engagement in a conflict can be best explained if one understands the motivation of the individuals taking part in it. The macro-situation can have an effect on the individual behaviour of the conflict.

- Abduction, the 'third way of doing science' (Axelrod 2005): conflict assumptions are deduced from my case studies and securitization theory but can be adjusted during the research process.

3 See Epstein: "Individual rationality is ,local' also, in the sense that the agent's expected utility calculation excludes any estimate of how his isolated act of rebellion may affect the social order" (Epstein 2006: 250). 
I think it is especially fruitful to analyze the expected vicious circle with an agent-based model because my constructivist assumptions underline the importance of interaction for the emergence of a social phenomenon. Furthermore, security analysis in general should include interactions because, as Clausewitz has made clear, war is never an isolated act but a succession of decisions and acts (Clausewitz 1952: 94f). According to Clausewitz, each conflict-party determines his own actions by assessing those of his opponent based on their "character, constitution, condition and circumstances" (Clausewitz 1952: 97f). What Clausewitz is describing is a "mutual reinforcement", which is relatively easy to demonstrate using agentbased models (see Gilbert 2009: 2).

In military sciences and military education, simulation methods have a long tradition. Computer simulations are used for the training of military personnel, as well as for the development of doctrines on different levels (Stahel 1999: 187). One example of this is Albert Stahel's and Pierre Allan's analysis of the Soviet War in Afghanistan using a dynamic model. This took into account the macro-combat interactions between the Afghan guerrilla forces and the Soviet and Afghan regular armies as well as the support for the guerrillas by the population (Allan and Stahel 1983).

The latter mentioned simulation was a system dynamic model. The main difference between the agent-based and the system-dynamic approach is that the former diverges from a 'methodological individualism'. This entails explaining macro-phenomena by means of the behaviour and actions of individuals. Although 'micro dynamics' are a subgroup of system dynamics which simulate individual behaviour, it has become more common to simulate individual behaviour with agent-based modelling techniques. Agents Based Models (ABMs) allow us to simulate the interaction of individuals and the diffusion of information as well as the analysis of networkeffects. The agent-based approach also enables us to analyze a macrophenomenon originating from the individually heterogeneous behaviour of agents. I attempt to answer my research question with an agent-based simulation and therefore situate my study in the realm of Analytical Sociology. I am interested in how macro-patterns of social behaviour are caused by individual behaviour and vice-versa. Since in an agent-based simulation each agent behaves according to his decision-rules within a defined environment,

4 See for example http://analyticalsociology.com/about/. 
I am able to reconstruct the macro-outcome from the definition of the micro-behaviour. Indeed, agent-based simulation "permits one to study how rules of individual behaviour give rise - or 'map up' - to macroscopic regularities and organisations" (Epstein 2006: 4). Studies applying agent-based models should be interested in regularity at the macro-level, which can be explained by a theory relying on micro-behaviour of agents.

In contrast to the agent-based approach, system dynamics are based on differential and difference equations. Such mathematical or equation-based models usually specify relationships between variables at the macro-level and are often displayed as stock and flow diagrams:

"System dynamics, as its name implies, models systems of interacting variables and is able to handle direct causal links, such as a growth in population leading to increased depletion of resources, and feedback loops, as when population growth depend on the food supply, but food supply depend on the level of the population" (Gilbert 2009: 18).

In a system dynamic model, the values for the dependent variables are calculated at each time step with the values of the variables at the previous time step, according to the differential or difference equations which make up the model. The relevant variables in the model can be borrowed from a theory, but the forms of the equations which define the system-behaviour are usually derived from statistical evidence, and not from theory (Gilbert 2009: 5).

None of the model-types presented above is generally better or worse for simulating social phenomena. Whichever type is more suitable in a specific project depends on the research question:

"The choice of agents versus equations always hinges on the objectives of the analysis. Given some perfectly legitimate objectives, differential equations are the tool of choice; given others, they're not. If we are explicit as to our objective, or explanatory criteria, no confusion need arise" (Epstein 2006: 29).

System-dynamic models are very useful when large populations of homogenous agents are studied because they deal with aggregates (Gilbert 2009: 20). Therefore, a system dynamics model is appropriate if I base my study on a theory which explains macro-mechanisms. On the other hand, an ex- 
planation on the micro-level is easier to formulate with an agent-based model, where the behaviour of individuals leads to the macro-phenomenon. If one needs to simulate heterogeneity among the agents or if the agents' behaviour depends on their past experience or memory, it is also useful to design an agent-based model (Gilbert 2009: 20). I consider here radicalization to be the process of ideological (re-)orientation that an individual undergoes. In my view, it is for this reason that the agent-based modelling technique is appropriate for modelling the securitization of Islam in Central Asia.

\subsubsection{Epstein's Conflict Model}

In order to embed my study in the current literature and in order to provide an outline of a well-known agent-based conflict model, I will briefly introduce Epstein's 'Modelling Civil Violence'. Epstein's study is of special interest to me because it analyzes, among other things, the impact of legitimacy on the dynamics of a civil rebellion. In his book 'Generative Social Science' Epstein presents two models: one in which a decentralized rebellion rises up against a central authority, and one where two different intrastate groups fight each other and the central authority tries to separate them. In this review I will only present the first model (Epstein 2006: 245ff).

Epstein develops an entirely theoretical model without testing his hypothesis with reference to a real case. His aim is to elaborate on the main dynamics of civil violence. There are two agent-types; the so called 'agents', representing citizens, and 'cops', who stand for the central authority. The agents can take part in the uprising (they are 'active') or they do not participate (they are 'quiescent'). They become active if they are aggrieved, which depends on their perceived hardship (uniform distribution among the agents) and on the legitimacy of the regime they are living in (exogenously given). ${ }^{5}$ A further factor is the risk aversion of the agents, which is heterogeneously distributed among the agents, but fixed for each individual's lifetime. The risk aversion factor influences whether the agents become active or not. The agents calculate at each time-step the perceived probability of being arrested, which also depends on the active agents and

$5 \mathrm{G}=\mathrm{H}^{*}(1-\mathrm{L})(\mathrm{G}=$ grievance, $\mathrm{H}=$ perceived hardship, $\mathrm{L}=$ legitimacy $)$. 
on the cops within their vision. ${ }^{6}$ During these calculations, the agents are rational, but because their calculation depends on their subjective vision and their decision (to become active or not), which is influenced by their specific risk-aversion, they are boundedly rational.

The following three rules comprise the micro-specification, which defines the agents' and cops' behaviour in Epstein's model. ${ }^{7}$

- Agent rule A: If $\mathrm{G}-\mathrm{N}>\mathrm{T}$ be active; otherwise, be quiet. (whereas $\mathrm{G}=$ individual Grievance; $\mathrm{N}=$ Netrisk, $\mathrm{R} * \mathrm{P} ; \mathrm{T}=$ Threshold $^{8}$

- Cops rule $\mathbf{C}$ : Inspect all sites within $\mathrm{v}^{*}$ and arrest a random active agent.(whereas $\mathrm{v}^{*}=$ cops' vision)

- Movement rule M: Move to a random site within your vision. (holds good for agents as well as for cops, whereas $\mathrm{v}=$ agents vision and $\mathrm{v}^{*}=$ cops vision)

I will not elaborate more on the details of this micro-specification, which can better be understood if one reads the original text of Epstein (2006: 245-270). The presentation of his model here only serves to display how the very simple agent rules presented above can lead to the following findings, which are interesting for my research purpose:

- Under an illegitimate regime, rebellion is more likely than under a legitimate regime. If the legitimacy of a regime steadily declines from a high state to 0 (no legitimacy at all), the probability for an uprising is much smaller than in a scenario where the legitimacy is reduced only a little but at once.

- As we see, a reduction of legitimacy can trigger rebellion. On the other hand, a reduction of repression can also lead to a rebellion

$6 \mathrm{P}=1-\exp [-\mathrm{k}(\mathrm{C} / \mathrm{A}) \mathrm{v}](\mathrm{P}=$ perceived probability to be arrested; $\mathrm{C}=$ number of cops; A = number of agents; $\mathrm{k}$ = parameter).

7 See for the implementation of Epstein's model into a NetLogo Model (Wilensky 2004).

8 G H (1-L) (whereas $\mathrm{H}=$ exogeneously given perceived hardship, heterogeneous among agents; $\mathrm{L}=$ legitimacy of the regime, exogeneous and equal among agents). 
- The society's ripeness for revolution can be measured by the average grievance, number of inactive agents and average risk aversion. ${ }^{9}$

These findings are especially relevant as many defenders of authoritarian regimes state that a reduction of repressive means in their countries would jeopardize political stability. On the other hand, human rights defenders would argue that the strong repression of Islamist groups, for example, against Hizb ut-Tahrir, only drives them to violence.

In contrast to Epstein I am primarily interested in the link between legitimacy and repression, or in what Schlichte (2009) calls the 'shadow of violence'. Securitization theory states that extraordinary means can only be implemented if the audience accepts the securitization. To answer my research questions, it is crucial to ascertain how authoritarian regimes establish legitimacy for their security policies and what impact this has on their opposing non-state actors. According to securitization theory, I assume that the violent (or extraordinary) means of a group are linked to the legitimacy the audience has ascribed to this group.

Unfortunately, social scientists using computer simulations as a method all too often pay little attention to the deduction of the assumptions used in the models and to the empirical survey of their outcomes. Instead, they develop very sophisticated and complex systems. But even the most sophisticated and complex computer model does not help us to understand social processes if it is not based on correctly deduced assumptions which are tested afterwards. For this reason, it is important to keep in mind the rules of social science research when computer simulations are used. Therefore, I pay as much attention to high-quality qualitative research as to an innovative computer model and describe my model with a standardized ODD protocol.

At no point in time should it be forgotten that a simulation is only a simplified model of reality and that it is not reality itself. Neither, therefore, should too much importance be attributed to the interpretation of the simulation itself despite the many advantages of the method. Instead, the simulation outcome can only be understood if it is thoroughly embedded in a case study.

$9 \overline{\mathrm{G}} \overline{\mathrm{B}} / \overline{\mathrm{R}}$, whereas $\overline{\mathrm{G}}=$ average grievance, $\overline{\mathrm{B}}=$ frequency inactive agents, $\overline{\mathrm{R}}=$ average risk aversion. 


\subsection{Databases, Country Reports and Country Profiles}

Apart from the qualitative research of primary and secondary literature, I used different databases, country reports and annually updated country profiles for my study.

Data used for the comparison of the countries and as input for the simulation stem from:

- CIA World Factbook (2012) https://www.cia.gov/library/publications/the-world-factbook/

- EIU, The Economist Intelligence Unit (2013): Democracy index 2012. Democracy at a standstill. A report from The Economist Intelligence Unit. The Economist Intelligence Unit Limited: https://portoncv. gov.cv/dhub/porton.por_global.open_file?p_doc_id=1034

- Freedom House: country reports http://www.freedomhouse.org/

- Gibney, M., Cornett, L., Wood, R., and Haschke, P.: Political Terror Scale (2013): http://www.politicalterrorscale.org/

- Human Security Report (2012): http://www.hsrgroup.org/humansecurity-reports/2012/overview.aspx

- International Institute for Strategic Studies: Military Balance (2012) http://www.iiss.org/en/publications/military-s-balance

- Reporter ohne Grenzen, country ranking (2013) https://www.reporter-ohne-grenzen.de/pressearchiv/ranglistenpressefreiheit/

- Transparency International, Corruption Perceptions Index (2012) http://www.transparency.org/cpi2012/results

- US State Department Country Reports on Terrorism (2013) http://www.state.gov/j/ct/rls/crt/2012/209983.htm

The CIA World Factbook provides country information for many issues such as society, economy and infrastructure. It is a reliable source of statistical data. The Military Balance provides annual information about global military capabilities and defence economics and is widely accepted as a reliable source for security studies. It is compiled by the International Institute for Strategic Studies which is located in the United Kingdom. The Political Terror Scale measures human rights violations committed by state 
actors. It relies on the same sources as the better known Cingranelli and Richards Human Rights Data Project (CIRI) but has improved its coding system (for further information about this difference see the project's website). Reporter ohne Grenzen ('Reporters without borders') annually publish an international ranking of the freedom of press. Transparency International does the same for perceptions on corruption around the world. As these organizations are impartial the rankings are judged as objective. The US State Department's Country Reports on Terrorism are used as an additional source of information concerning terrorist incidents in the Central Asian countries. All information provided by state actors is handled carefully in my study as these actors are prone to political bias (in this case for example with regards to the classification of groups as either 'extremist' or 'terrorist').

In order to validate my simulation results I use the following databases:

- Global Terrorism Database (GTD)

http://www.start.umd.edu/gtd/

- Association of Religion Data Archives (ARDA)

http://www.thearda.com/internationalData/

Both databases are from the US. GTD is a project of the University of Maryland and of the National Consortium for the Study of Terrorism and Responses to Terrorism (START) which is a Center of Excellence of the U.S. Department of Homeland Security. GTD is available online "in an effort to increase understanding of terrorist violence so that it can be more readily studied and defeated" (GTD). The data provided by GTD are collected from news articles. I regard the database as very valuable because it allows us to search for many different variables, such as the perpetrators of an attack, the weapons used and the targets of the attack. Furthermore, every incident is briefly described which provides the user of the database with additional information such as the sequence of events.

ARDA is an interesting database to survey and compare the religious landscapes of different countries. It is part of the Religion and State project (RAS) of Bar Ilan University in Ramat Gan, Israel. ARDA gives an overview of the countries' histories and religious demographics and provides statistical data on religious adherents. Furthermore, it provides religious freedom indices on government regulation, social regulation and govern- 
mental bias towards certain religions, and lists the constitutional articles regarding religion.

In order to visualize the contemporary diffusion of religious preferences and attitudes among Muslims in Central Asia I referred to the following databases and reports of the US Pew Research Center (PEW):

- Global Religious Futures Project http://www.globalreligiousfutures.org/countries

- The World's Muslims: Unity and Diversity (2012): http://www.pewforum.org/files/2012/08/the-worlds-muslims-fullreport.pdf

- The World's Muslims: Religion, Politics and Society (2013) http://www.pewforum.org/files/2013/04/worlds-muslims-religionpolitics-society-full-report.pdf

PEW provides representative survey data on different topics and religious issues and is extremely useful for my purpose because it enables us to contrast official data with information from face-to-face interviews with ordinary Muslims. PEW data for Uzbekistan is judged most problematic. Here, some questions are missing, as they were not asked in order "to avoid offending respondents and/or risking the security of the interviewers" (PEW 2012: 117). Furthermore, "large scale labor migration patterns may have contributed to fewer interviews with male respondents" in Uzbekistan (PEW 2012: 119).

For discussing the state regulation of religion and of religious groups I additionally rely on:

- Amnesty International: country reports http://www.amnesty.ch/de/laender

- United States Department of State Bureau of Democracy, Human Rights and Labor: International Religious Freedom Reports http://www.state.gov/j/drl/rls/irf/

It is important to mention that it is difficult to verify information concerning religious freedom as western interest in this issue is generally restricted to the promotion of human rights. Many reports therefore refer to each other. ARDA, for example, refers to the CIA World Factbook, United Nations 
Human Development Reports and the US State Department's International Religious Freedom Reports. PTS refers to Amnesty International and United States Commission on International Religious Freedom (USCIRF). The PEW survey data therefore provides an interesting addition to these data. Furthermore, the inclusion of some publications and articles in Russian should help to avoid an excessively western- (and specifically US-) oriented perspective on the topic. 

PART I

REVIVAL OF ISLAM:

CASE STUDIES OF ISLAMIC GROUPS 



\section{Features of Central Asian Folk Islam}

The revival of Islam in Central Asia cannot be analyzed without understanding the local forms of Islam prevalent in the region. Therefore, I first of all highlight the most important aspects of Central Asian Islam. One important feature is the prevalence of the Sunni Hanafi School of law and their adaptation of local customs; how this combines with pre-Islamic rituals, and the influence of Sufism.

\subsection{General Remarks on Islam}

\subsubsection{A Heterogeneous Religion}

A special feature of Islam is that it has developed heterogeneous characteristics in different parts of the world. Moreover, these many local forms of Islam are themselves not homogenous but internally diverse, a fact which all too often goes unnoticed, as Khalid makes clear:

“Totalizing statements about Islam [...] grossly misrepresent this reality. Characterizations that present Islam simply as wicked or tolerant are equally incorrect. Muslims can draw any number of lessons from Islam. The tradition is much too rich and diverse to be reduced to a single evaluative adjective" (Kha$\operatorname{lid} 2007: 24)$.

Alongside the development of different cultural understandings of Islam over time has been a concomitant evolution of diverse theological debates about the proper way to practice religion (Schubel 2009: 279). The catch- 
words jihad and sharia, whose true meaning will be clarified in these pages, are used by Islamists as well as by those countering the 'Islamic threat', with both sides perceiving Islam in an essentialist way as a unified and homogenous religion (which is either totally right or totally wrong, depending on the point of view).

First of all, however, a clear distinction has to be made between 'everyday' Islam versus 'scriptural' Islam - a distinction that has gained ground in the current academic discourse on Islam in Central Asia (Epkenhans 2011: 81). As Khalid explains:

“ 'Customary' or 'local' understandings of Islam are countered by more 'normative' versions of Islam that draw their authority from greater adherence to injunctions or strictures elaborated by scholars who specialize in fiqh or other aspects of Islam's normative tradition. This tension between different ways of understanding Islam creates the most characteristic inner dynamic in Muslim society" (Khalid 2007: 24).

As we will see below, in the contemporary 'revival of Islam' in Central Asia, different understandings of the religion are gaining influence and are partially competing against each other. Nevertheless, it should not be concluded that either the scriptural or the local interpretations of Islam themselves are homogenous or have reached the end of their development.

Contemporary research on Central Asian Islam is restricted to two main fields: anthropological research on the private practice of religion on the one hand and a securitized research discourse on Islam on the other. In the latter field (where my study is situated as well), the tendency to regard Islamists as the main threat to the existing regimes has endured from Soviet times up until the present day: "The difference is mainly that the 'Islamic threat' was formerly seen as an antidote to Soviet ascendancy, while now it is viewed as a danger for stability and a potential vector for international 'Islamic terrorism' " (Schoeberlein 2009: 102). In order to distance ourselves from this overly simplistic view, I consider it important to embed the discussion of radical Islamist groups in the region's religious landscape. As such, although this is a security study, I will first of all analyze Central Asian mainstream religious practices before focusing on extremist and violent groups. In this way, I first introduce the inner-Islamic debate and only then turn to the official religious policies. As I show, since Soviet times it 
has been common to speak of categories such as radical versus moderate and parallel versus official Islam (Epkenhans 2011: 82). However, it is important not to oversimplify or restrict ourselves to only those theoretical terms which are problematic for understanding the facts because they imply distinctions where there are grey zones and evoke contradictions where there may be none. For example, the official Islam changed its nature over decades of Soviet rule. Representatives of both official and underground Islam often came from the same background and maintained contact with each other. Yet today terms such as 'traditional' or 'foreign' Islam prevail in Central Asian countries: it would be very simplistic to limit descriptions of Islam to only these two categories, though. As we shall see, Salafism, for example, not only came to the region by contemporary Arab influences but has its local roots in Central Asia as well.

\subsubsection{Islam and Politics}

The Prophet Muhammad was not only the religious but also the political leader of the first Muslims. Subsequently, it is often mentioned that politics and religion are necessarily closely intertwined in Islam, however I agree with Khalid, who opposes this view:

"The earliest caliphs claimed both political and religious authority, but already by the beginning of the third Islamic century, the ulama [the learned of Islam] had supplanted the caliphs as guardians of the faith. The political might of the caliphate, in contrast, disappeared with the rise of numerous independent dynasties, whose legitimacy came primarily from military conquest" (Khalid 2007: 27).

This makes clear that throughout history, religious and political authorities were for the most part separated - a division which is also supported by appropriate theories. For this reason, I do not want to imprudently mix the history of politics and religion. Nonetheless, it is undeniable that many dynasties and emperors in Central Asia did try to legitimize their rule by religious means, as Naumkin makes clear:

"The Hanafi clergy and scholars played an important role in the administrative and political life of medieval Central Asia. The head of the Hanafites in Bukha- 
ra (ra'is) even acquired hereditary power in Bukhara in the eleventh century, which his family wielded until the Mongol conquest in the thirteenth century" (Naumkin 2005: 8).

Such a bond between Islam and politics can be observed today in the organizational structure of the mahalla - the Central Asian neighbourhood solidarity network. Even un-Islamic regimes took advantage of the mahalla's organizational structure. The mahalla was a "partly self-governed unit which had a mosque and a maktab (an Islamic primary school)" (Salmorbekova and Yemelianova 2010: 214). It was genuinely Muslim and reserved an important role for the imam. More recently, the authorities of the USSR and the newly independent states have made use of these networks to exert control over Islam.

I am especially interested in the role of religion in contemporary Central Asia and in the legitimizing effect the reference to religion has. I therefore summarize the ancient history of Central Asia by emphasizing how the regimes legitimized their rule with reference to religion and heredity (either by tracing back their ancestry to the Prophet Muhammad or employing Sufis as counsellors, as we will see in this chapter). As we can see, Islam played a role in Central Asian politics in the past to the extent that political regimes profited from the existence of religious authorities. This, however, does not mean that politics and religion have always necessarily been intertwined. On the contrary, this only serves to demonstrate that in some eras religious and political leaders were closer to each other than in other times.

Who is promoting the revival of Islam in the post-communist countries of Kazakhstan, Kyrgyzstan and Tajikistan? I will show in the next chapters that the 'revival of Islam' in Central Asia is not a onedimensional development and introduce the various actors involved in this process. I first of all present general features of Central Asian Islam before I explain how folk Islam has been undergoing a revival since independence. After this I turn to political Islam and to groups which aim at transforming society. 


\subsection{SunNi Hanafi Madhab}

The contemporary disputes among state and non-state actors in Central Asia have a lot to do with 'traditional Islam' and 'foreign influences' on Islam. The conflicts take place between folk Islam and Sufis, conservative Hanafites, fundamentalist Salafis (also called Wahhabites, but this term is not correct in this context, as I show), and other reformist movements. In order to understand the different perceptions, for example, on the role of local customary law, or of worshipping at shrines or attitudes to clothing, I will here give first of all an overview of Sunnis and Shiites as well as of the different schools of Islam.

\subsubsection{Sunnis and Shiites}

Muslims are divided into two different branches: Sunnis and Shiites. In the beginning of Islam, Muhammad, the most important Prophet, not only confessed this new religion but was also the political and military leader and Imam (the person who leads the Muslim prayer) of the Muslim community. After his death, the four caliphs who were elected as his successors were called the 'righteous' caliphs, because the time span of their rule was regarded as the ideal Muslim period (Elger 2002: 29).

After the death of the fourth caliph, the Sunnis accepted the leadership of the Umayyads (661 to 750, centred in Damascus) and the Abbasids (750 to 1258 , centred in Baghdad), who wielded a great influence on the culture and political order of Muslim society (Elger 2002: 29). From the $9^{\text {th }}$ century, however, the Muslims were no longer united as one political entity (Elger 2002: 30). From this point on, the Abbasid caliphate was ruled by several dynasties of local authorities (Sultans). At the same time, the Sunnis began to elaborate political theories which strengthened the authority of the caliphs and Sultans:

"For the early Sunni jurists, the only legitimate form of government was the Caliphate; only the descendent of the Prophet was considered as the religious and political leader of the umma. The caliphs were not regarded as theocrats with unconfined power, but as upholders of the divine commandments (shari'a) and defenders of the Muslim community" (Elger 2002: 33). 
The succession of the Prophet Muhammad led to one of the most relevant divergences in the Muslim community - the one between the Shiites and the Sunnites. The Shiites regarded only Ali (the last of the four 'righteous' caliphs, who died in 661) as legitimate and argued that Muhammad had preferred him as his successor because of his piety and his intellectual qualities (Elger 2002: 34). The Shiites therefore declared only the descendants of Ali and his wife Fatima as legitimate caliphs and imams (Elger 2002: 34). When the first Son of Ali, Hasan, ceded from power in 661 in favour of the Umayyad caliph, and his younger brother Husain opposed the Umayyads (and was later killed), Shiites and Sunnis split. I will not go into the details of this division nor explain further distinctions among the different groups of Shiites because the great majority of Central Asians are Sunni Muslims and the current conflicts in Central Asia are only among Sunnis.

Table 1 shows the percentages of Muslims in the population of the Central Asian states as well as the percentages of Sunnis and Shiites in these countries. The biggest Shiite minority lives in Tajikistan; they are Ismailites and comprise eastern Iranian peoples and the inhabitants of Badakhshan region (Atkin 2009: 307).

Table 1: Muslim Population in Central Asia: Sunnis and Shiites

\begin{tabular}{|l|l|l|l|l|}
\hline & Kazakhstan & Kyrgyzstan & Tajikistan & Uzbekistan \\
\hline Sunnis & $70.1 \%$ & $75.0 \%$ & $94.0 \%$ & $92.9 \%$ \\
\hline Shiites & $0.1 \%$ & $<1 \%$ & $4.0 \%$ & $0.1 \%$ \\
\hline
\end{tabular}

Source: ARDA 2013

\subsubsection{Hanafi School of Law}

Islamic Jurists were to look for the answers to judicial subjects first of all in the Quran or in the reported deeds and sayings of the Prophet Mohammad (hadith) (Elger 2002: 54). Since the $9^{\text {th }}$ century, jurists in Sunni Islam were commonly not supposed to interpret the written sources in their own way but rather had to refer to older authorities for seeking answers to juridical questions (Elger 2002: 55). In this way, local juristic traditions emerged and distinct dogmatic schools (madhab) evolved (Elger 2002: 55): 
"The beginnings of the schools of law in Islam go back to the late Umayyad period, or about the beginning of the second Islamic century, when Islamic legal thought started to develop out of the administrative and popular practice as shaped by the religious and ethnical precepts of the Qur' an and the hadith" (Ziadeh 2009: 389).

From a total of seven, four madhabs have continued to this day and are generally regarded as legitimate (Ziadeh 2009: 290). They bear the name of their founders (Elger 2002: 55):

- Abu Hanifa (died in 767): Hanafi school

- Malik ibn Anas (died in 795): Maliki school

- Ash-Shafi'i (died in 820): Shafi'i school

- Ahmad ibn Hanbal (died in 855): Hanbali school

Each dogmatic school has its own principles and methods for finding justice. The concept of 'imitation' is called taqlid. It leads to different interpretations of what is permitted by the different schools of law. Elger explains such differences using the example of the right of women to divorce: Hanafites say that women are only permitted to divorce from their husband if he is impotent and therefore cannot consummate the marriage. Malikites, on the other hand, accept other grounds such as physical and mental deficits, shortcomings in maintenance obligation, bad treatment or abandonment (Elger 2002: 55).

In Central Asia, as in the Islamic world more widely, ${ }^{1}$ most people follow the Hanafi dogmatic school (Schoeberlein 2009: 98). In the context of the contemporary conflicts between 'folk' or 'popular' Islam and a more 'scriptural' interpretation of the Quran, it is important to stress the special position of traditions and customary law in the Hanafi madhab. It is often mentioned that compared to other schools, the Hanafis are "tolerant of preIslamic popular customs and rites" and legitimized some of the tribal and customary norms (Salmorbekova and Yemelianova 2010: 213). Pre-Islamic traditions were incorporated into their version of Islamic law and "Hanafi jurists often referred to custom in their ruling" (Gerholm and Mubarak 2009: 492f). In rural areas both Muslim clergy and clan councils adminis-

1 It is estimated that around one third of the Muslims worldwide follow the Hanafi madhab (Ziadeh 2009: 392). 
tered justice, and under Hanafi madhab, they could incorporate their local unwritten customary law ('adat or 'urf) into Muslim jurisdiction (Elger 2002: 58). An example of Islamized traditions is the (genuinely zoroastrian) spring celebration which is connected to the visitation of the graves of ancestors and saints (Sayyil or Sayyil-bayram) (Naumkin 2005: 7). Another example is the (genuinely shamanistic) tatters at trees or "the kissing of headstones and the rubbing of graveside dust over one's face" (Naumkin 2005: 8). Indeed, the tolerance of pre-existing popular customs and rites made Hanafism successful in Central Asia (Naumkin 2005: 7).

Maturidi, an important Central Asian jurist, was the founder of the Maturidiyah school of thought (Khalid 2007: 25). As Naumkin explains, the Maturidiyah became the form in which Hanafism turned into the dominant madhab in Transoxiana in the tenth century. Indeed, it was Maturidi who, "legitimized the interwovenness of Hanafi Islam with traditional clan and tribal networks which remained almost unchanged through the centuries" (Salmorbekova and Yemelianova 2010: 214). (Naumkin 2005: 7). In fact, customary law played such a significant role in Islamic law that it was eventually incorporated as a material source in the latter in the $19^{\text {th }}$ century by a Hanafi jurist (Gerholm and Mubarak 2009: 492f).

Hanafism not only "facilitated the Islamization of pre-Islamic norms and traditions," but it also "helped to escape tensions between the new and old systems of beliefs, thus accelerating the smooth adoption of Islam" (Naumkin 2005: 7). The possibility to continue old traditions when adapting the new religion made conversion easier for the Central Asian societies. As many authors state, this madhab is more open than others: "On the whole, the legal doctrines of Abu Hanifa evidence a liberality and a respect for personal freedom that are not that pronounced among other jurists" (Ziadeh 2009: 390).

\subsubsection{Demarcation: Hanbali School of Law and Wahhabism}

Whereas the Maliki and the Sahfi'i schools of law are not important in the Central Asian context, the following point should be made concerning the Hanbali school and Wahhabism: what today is often regarded as the foreign influence on Islam in Central Asia and what is popularly called 'Wahhabism' or Salafism, is a scriptural interpretation of the Quran, which is mainly based on the Hanbali School of law. Ahmad ibn Hanbal is sometimes 
considered more of a traditionalist than a jurist because he never wrote about fiqh (Ziadeh 2009: 395).

In the eighteenth century, the school was strengthened by "Ibn' Abd alWahhab and his reform movement in Arabia, which aimed at returning Islam to its simple and pristine beginnings, depending on the Qur' an and the sunnah instead of later scholars" (Ziadeh 2009: 395). Abd al-Wahhab, "dismissed the long tradition of Muslim jurisprudence (fiqh), which had accepted a much larger range of sources as authoritative" (Khalid 2007: 45). (For the disputes between Hanbalites and Hanafites during the Abbasid caliphate see section 5.1.2.) Petitionary prayer, supplication and the visitation of shrines were regarded by Abd al-Wahhab as compromising God's unity (shrik) and were seen as examples of impermissible innovation (bid'a) (Khalid 2007: 45).

"Even poetry in praise of the Prophet or other exalted figures, a genre that had produced some of the noblest verse in the Muslim world, was for "abd al-Wahhab merely a form of idolatry" (Khalid 2007: 45).

Other Muslims, mainly Shiites and Sufis, were denounced as infidels (Khalid 2007: 45). As Khalid shows, Wahhabism went on to become the state religion of the modern kingdom of Saudi Arabia:

"In 1746, the two ['Abd al-Wahhab and Muhammad ibn Sa'ud] together declared war (jihad) on all Muslims who did not share their views on Islamic purity. [...] Wahhabis were fond of destroying tombs and shrines, demolishing domes over houses and palaces, burning books other than the Qur'an, forcing people to pray communally, and policing moral conduct and personal behaviour" (Khalid 2007: 46).

As we will see in the next sections, the aversion of Wahhabi Islam towards, for example, worshipping at shrines is shared by contemporary Islamists. Because of the explicitly puritanical approach of the Wahhabis and their opposition to folk Islam in Central Asia, "the term [Wahhabism] has come into indiscriminate use to denote any and all expressions of nontraditional Islam" (Khalid 2007: 46). This means it is often used inappropriately. Already during Soviet times, “' 'Wahhabite' was employed as a general term of disqualification against all the fundamentalist currents that appeal to a 
literal reading of the Quran and believe that Islam can be reformed only by returning to its origins" (Peyrouse 2007: 45). It is true that those accused of being Wahhabis often share the opinion that Islam has to be cleaned from modern accreditions (Rotar 2004b). However, those accused of being Wahhabites are often influenced neither by the teachings of Abd al-Wahhab nor the Saudis directly (Peyrouse 2007: 45). As Schoeberlein explains, Wahhabiya per se has had little impact in Central Asia (Schoeberlein 2009: 106) and the Central Asian governments use the term interchangeably with fundamentalism for "[...] virtually any Islamic orientation that they deem politically unacceptable, and they treat these terms as synonymous with 'Islamic terrorist" " (Schoeberlein 2009: 105). Khalid therefore suggests using the term with circumspection (Khalid 2007: 47). I agree with Khalid and Peyrouse and it seems important to me to draw a distinction between devout Muslims wishing to follow the life of the earliest Muslims (or Salafis), and those who follow the dogmatic school of Abu Hanifa and Ibn'Abd alWahhab specifically (Wahhabis).

\subsection{SUFISM}

From the $12^{\text {th }}$ century on, Central Asian Hanafism absorbed elements of Islamic mysticism, ${ }^{2}$ called Sufism (Salmorbekova and Yemelianova 2010: 214). Indeed, all religions know their own mystic trends, which have often influenced each other (Schimmel 1985: 339). Sufism was important for incorporating pre-Islamic rituals into Central Asian Islam and for developing syncretic characteristics. Buddhism in particular had a great impact on $\mathrm{Su}-$ fism. The Muslim faith in Central Asia also incorporated pre-Islamic behaviours. In fact, in many cases holy places, where Christians or Hindus

2 What is mysticism? Chittick (2009: 207) criticizes this term as being vague and implying a negative value judgment. Schimmel specifies mysticism as "[in the broadest sense] the consciousness of one reality, regardless of whether one calls this 'wisdom', 'light', 'love' or 'nature'. However, such definitions remain at best signposts since the goal of a mystic, that oneness which is inexpressible, cannot be understood or explained by any normal act of perception" (Schimmel 1985: 16). 
used to pray, later became Sufi holy sites, and legends about older saints were applied to the new ones (Schimmel 1985: 339).

Sufism is not bound to the Shia-Sunna split but had a tremendous impact on both in Central Asia (Schoeberlein 2009: 104); neither is it bound to a specific school of law (Johansen and Talib 2009: 207). "If kalam and jurisprudence depended on reason to establish categories and distinctions, the Sufis depended upon another faculty of the soul to bridge gaps and make connections" (Johansen and Talib 2009: 210). Indeed, Sufis are rather ignorant of the differences and theological debates between the dogmatic schools because they prefer to focus on the immediate gnosis (Schimmel 1985: 35), as Johansen and Talib make clear:

"In general, Sufis have looked upon themselves as Muslims who take seriously God's call to perceive his presence in the world and the self. They generally stress inwardness over outwardness, contemplation over action, spiritual development over legalism, and cultivation of the soul over social interaction" (Johansen and Talib 2009: 207).

It therefore seems no surprise then that the most elite expression of Islamic teaching has also been produced by Sufis (Johansen and Talib 2009: 207) even though Sufism is often associated with folk Islam.

Generally, Sufism is often contrasted with 'orthodox' Islam represented by the ulama, ${ }^{3}$ but in Central Asia there is no broad opposition - political or religious - between the two (Schoeberlein 2009: 104). The main difference among ulama and Sufis is that:

“ 'Ulama' aspire to receive the inspiration from Allah through the perfection of everyday Islamic rituals with emphasis on the external (zahir) teaching of the Holy Qur'an. The pirs evolve a spiritual praxis to construct the presence of God (nur) in man by focusing on the inner (batin) teaching of the Holy Qur'an" (Ewing and Mannan 2009: 378).

3 See as an example: "Many 'ulama' (Islamic scholars) overtly show their antagonism to the presence, modes of teaching and scholarship of the Sufis. Among the critiques are the reformist 'ulama' of highly influential Doebandi School and its networks of madrasas (Islamic religious schools)" (Ewing and Mannan 2009: 378). 
Whereas the legalistic or scholarly forms of Hanafi Islam were widespread in Central Asian cities, Sufism was more prevalent in rural areas and among tribal communities (Yemelianova 2010: 19). As I demonstrate in section 5.1, nomads were primarily Islamized by Sufi orders (Schoeberlein 2009: 99).

First of all, though, I concentrate on the distinct Sufi rituals, which are very important for folk Islam in Central Asia, after which I shed light on the importance of Central Asia as a region, from where Sufi brotherhoods (tariqa) originated and went on to spread across the globe (Schoeberlein 2009: 104). Finally, I take a closer look at the political involvement of the Naqshbandiyah tariqa - from the side of both the ruling class and the opposition.

\subsubsection{Sheik, Silsilah, Kanaqah and Zhikr}

What distinguishes a Sufi Muslim from other Muslims? Whereas an ordinary Muslim has to pray namaz five times a day and visit mosque at least every Friday (as well as pay zakat to the poor and go to Mecca for hajj), the Sufi has more and different obligations or involvements. The main features of Sufi practice are (Sultanova 2007: 3):

- Hierarchy within a constant number of members of the congregation (led by shaykh, pir or imam)

- Line of succession (silsilah)

- Community meetings at a kanaqah or other religious places

- Performance of dhikr ("Remembrance of God")

Sufis follow a master (shaykh or pir) who can trace his own masters back to the founder of a tariqa, or even to the Prophet Muhammad. This line of succession is called silsilah, as Johansen and Talib explain:

"Like other branches of Islamic learning, Sufism has been passed down from master [...] to disciple, and the chain of transmission (silsilah) leading back to the Prophet has been considered an important part of the master's credentials" (Johansen and Talib 2009: 209). 
Establishing lineage, therefore, is an important aspect of Sufism. Usually pirs, "claim that they inherit their spiritual power from either a pious Sufi ancestor or from their connection to the shrine of a past Sufi," but they also attain their spiritual quality through meditation and spiritual practice (Ewing and Mannan 2009: 378). "The masters' fundamental concern [...] is to shape the character [...] of the disciple so that it conforms to the prophetic model" (Johansen and Talib 2009: 210). The pir accepts the murid as his student in a ceremony of initiation, in which the student has to pledge a vow of fidelity and receives a blessing and the clothes of the tarīqah, which often consists of a special hat (Schimmel 1985: 331). As for the "remembrance of God", the ritual invocation called $d h i k r$, each tariqa has its own methods and practices for this.

The pir instructs his students individually and leads the five prayers in the khanqah, the Sufi centre (tekke in Turkish, see Johansen and Talib 2009: 234). The kanaqah usually consists of a mosque, living quarters for the students as well as for guests, and sometimes a madrasa (Islamic college). The pir lives there with his family and this is usually where one can also find a shrine of a deceased pir (Schimmel 1985: 328). Life in the kanaqah is organized in a strongly hierarchical way, usually based on virtue; however the hierarchy could also be utilized for the accumulation of personal power or for political purposes. The most devoted murid is designated a khalifa, the successor or representative of the pir, to which he is bound by the spiritual chain of teachings. He leads the kanaqah after the death of the pir or is sent by him to other places to preach and spread the tarīqah (Schimmel 1985: 333). Sometimes outstanding successors found their own tariqa.

Sufism is not easy to analyze because it is a multi-dimensional phenomenon and therefore I can reach very contradictory conclusions about it (Schoeberlein 2009: 104). What I can say, though, is that the visitation of shrines, which are often dedicated to deceased Sufis, is an important part of Sufism. Many Central Asians regard "the activities associated with such holy places $[\ldots]$ the most prominent features of their everyday observance of Islam" (Schoeberlein 2009: 105). Furthermore, “[...] Sufi rituals consist of the recitation of prayers, poems, and selections from the Qur'an and methodical repetitions of divine names (zikr) or Qur'anic formulas, such as shahadah" (Sultanova 2007: 3). Each Sufi order has its own methods for following the spiritual path by their daily devotional exercises and activities 
(Sultanova 2007: 3). As Khalid points out, the diverse attitudes of Sufi orders towards society in general goes hand in hand with different attitudes towards politics and judicial Islam in particular. So whereas, for example, the prevalent Sufi order in Central Asia, the Naqshbandiyah, does practice the dhikr silently and in a 'sober' manner, other orders might even place the greatest emphasis on social deviance such as "going around naked, consuming narcotics and hallucinogens, renouncing work and reproductive sexuality" (Khalid 2007: 27), though such practices are not common among Central Asian Muslims.

\subsubsection{Naqshbandiyah}

Central Asia was "one of the key regions from which Sufism spread widely in the Islamic world" (Schoeberlein 2009: 104). Several tariqa have their origin in Central Asia. For example, Abu Sa'id ibn Abi'l-Khair, born in Khorasan in 967 AD, was the first Sufi master to establish monastic rules for his students albeit without founding a tariqa himself (Schimmel 1985: 343). Najmuddin Kubra, was another pir, born in Khiva in 1145 AD; he founded the Kubrawiyah tariqah, and became important to the Naqshbandiyah tariqa (Schimmel 1985: 364). And then there was Baha'uddin Naqshband, born in 1318 in a village near Bukhara; the founder of the most important Sufi order in Central Asia, the Naqshbandiyah.

Naqshband belonged to the Central Asian spiritual tradition of Yusuf Hamadhani, who himself was the master of Ahmad Yasawi and Abdul Khaliq Ghijduwani (Schimmel 1985: 515). They spread Hamadhanis teachings in Central Asia, and Ghijduwani gave Naqshband his spiritual induction. Naqshband was first of all active in Bukhara and became the patron saint of the city (Schimmel 1985: 515). His tariqa not only enhanced its spiritual influence but also established relationships with traders, finally became heavily politicized, and gained control of the Timurid court (Schimmel 1985: 515). Especially when the tariqa was led by Khwaja 'Ubaidullah Ahrar (1404-90) (who had followers even in the Indian Mughal Empire), the Naqshbandiyah had a strong influence on politics (Schimmel 1985: 516). It was only during the early $19^{\text {th }}$ century that the order's intellectual and organizational centre moved to India, and was led by Ghulam 'Ali (Algar 2009: 219). Schoeberlein further attests to the importance of this Sufi order: 
"The Naqshbandiyah Sufi order [...] became one of the most influential Sufi orders across the Muslim world, and Bukhara remained a spiritual center of regional importance even after the Russian conquest, as Bukhara madrasas continued to attract students and scholars from many parts of the eastern Islamic world" (Schoeberlein 2009: 100).

Even now then, the Naqshbandiyah Sufi order remains the most important Sufi order not only in Central Asia (as we will see in section 2.4) but also in the wider Islamic world.

Contrary to other orders the Naqshbandiyah does not place much value on the monastic or lonely life (Schimmel 1985: 354f). A special feature of the Naqshbandiyah is that its members do not have to leave society but can (or even should) take part in the political life. For example, it was the conviction of the Khwajas (Naqshbandi order led by Khwaja 'Ubaidullah Ahrar) that the execution of political power is a duty since they thought that only in this way would one be able to implement the Godly law in each area of life (Schimmel 1985: 516).

The Naqshbandiyah is a pragmatic order which stresses the exoteric side of Islam more than other orders. Johansen and Talib distinguish between 'sober' and 'drunken' Sufism, and in this regard the Naqshbandiyah, would probably be classified as 'sober Sufism' (Johansen and Talib 2009: 213). Naqshbandis practice the quiet dhikr, and thereby distinguish themselves to a great extent from dancing or howling dervishes (which are better known in the West) (Schimmel 1985: 517). The return to the prophet and to the first period of Muslim society (salafiyah) is another feature of the Naqshbandiyah tariqa which distinguishes itself from other brotherhoods (Halbach 1989: 221).

"The leading characteristics of the Naqshbandiyah are strict adherence to the shari'ah, a sobriety in devotional practice that results in the shunning of music and dance and a preference for silent dhikr, and a frequent (although by no means consistent) tendency to political involvement" (Algar 2009: 222).

Although I often mention that Salafis oppose Sufism, it cannot be concluded that all Sufi orders oppose Salafi ideas as well because, as we see here, the Naqshbandiyah incorporates important Salafi features. It would be very interesting to elaborate on the connection between these two on first glance 
contradictory interpretations of Islamic practice, but this would go beyond the scope of this study.

\subsubsection{The Resistance Potential of Sufism}

Sufism played an important political role in Central Asia not only on the side of the ruling élite, but also as an opposition force at different instances in history. The order, for example, gained prestige by organizing jihad against non-Islamic expansionist regimes such as the Buddhist Oirats and Kalmuks (Halbach 1989: 220). In the $19^{\text {th }}$ century, "Sufi figures led some of the major revolts against rulers, including the resistance to Russian occupation of the North Caucasus led by Imam Shamil (1797 - 1871) and the Andijan Uprising of 1898" (Schoeberlein 2009: 104). Thereby, their strength was based on the Sufi relationship between murid and pir (Halbach 1989: 213).

Because of such events Sufism was often characterized as a 'militant motor' of Islamic resistance against tsarist Russia and later on against the Soviet Union (Bräker 1989: 135; Halbach 1989; Bennigsen and Broxup 1983; Bennigsen and Wimbush 1985). However, Schoeberlein cautions against drawing simplistic political assessments about Sufism in general because Sufism has a multi-dimensional reality (Schoeberlein 2009: 104). He therefore criticizes Bennigsen for his conclusion regarding the strength of underground Islamic organizations during Soviet times - especially Sufi brotherhoods - as a destabilizing factor in the USSR (Schoeberlein 2009: 100). Yet it cannot be denied that on several occasions Sufism was able to increase or maintain its influence in Central Asia because it escaped state repression under tsarist and communist rule. The Yasawiyah and Naqshbandiyah, for example, became widespread in the Volga-Urals region during the tsarist repression of Islam owing to the fact that for the authorities it was more difficult to control these than the legalistic Islam prevalent in the cities (Yemelianova 2010: 19). As Yemelianova further states, under tsarist rule, Sufism "could not be easily controlled and monitored by the authorities" (Yemelianova 2010: 19). Similarly, Halbach mentions that during the Soviet Union Islam was able to survive as an 'underground Islam' because of the important relationship between teacher and student, which was not necessarily bound to the mufti or a mosque (Halbach 1989: 213). I assume therefore that the fact that Sufism could survive the strong Soviet repres- 
sion of religion might not be so much due to the ideological foundation of the Sufi orders but rather to the organizational networks of the brotherhoods. The Soviet attempts to eradicate religion (which were based on the organizational structure of their primary target - the centralized Orthodox Church) therefore failed to a great extent to reach their goals regarding Islam. Interestingly, the personal relationships between pirs and students and the private worship of holy sites that persisted during the Soviet era still retain a greater importance than institutionalized forms of religion in Central Asia today. The flexibility and inconceivability of Sufism with regards to politics might be one reason why contemporary Central Asian regimes have not yet adopted a clear stance towards this important strand of Islam which, at certain points in history part of the elite and at others part of the opposition, has demonstrated an enduring potential to mobilize the masses.

\subsection{Folk IsLAM: SAINTS CULTURE AND MAZAR WORSHIPPING}

If the resistance potential of the Sufi brotherhoods was as great as Bennigsen supposed during the Cold War, one had to expect that the end of the Soviet rule would see a noteworthy resurgence of Naqshbandis (Algar 2009: 222). Whatever the case may be, there are authors who state that the Naqshbandiyah not only shaped politics during the Timurid and Shaibanid empires but still enjoy a considerable influence on the region today (Salmorbekova and Yemelianova 2010: 214; Halbach 1989: 220). Sufism is still important in Central Asia in two ways: "the intellectual appeal of Islamic mysticism has remained strong, and the sense of social cohesion provided by the Sufi organizations has been important" (Johansen and Talib 2009: 219). The indirect social power which pirs still have on society is undisputed. People who stem from an important Sufi family are called khoja, and still play an prominent role in religion and politics today, "regardless of their own religious activity" (Schoeberlein 2009: 104). Peyrouse argues that the khoja families were successful, "in maintaining their positions via a patronage system and traditions of endogamy that are still in existence today [...] even during the Soviet system [...] in which favouritism and a corporatist spirit ruled" (Peyrouse 2007: 44). These families dominated in the cultural, educational, scientific and medical domains Soviet Russia and 
even the qaziyat were led by members of these families (Peyrouse 2007: 44). ${ }^{4}$

Regarding the impact on politics in Central Asia, it is interesting to note that whereas in the past, the militant factor in Sufism was stressed, today Sufism is often regarded as a mitigating factor for Central Asian Islam. Scholars and politicians are, "supporting the notion that Sufism creates a safe buffer between Muslims of this region and the more radically oriented Islam of the Middle East" (Schoeberlein 2009: 104). However, it is wrong to presume that Sufism is a more moderate form of Islam than purist interpretations simply on the basis of its incorporation of syncretistic and 'preIslamic' rituals (Schoeberlein 2009: 104). One thing, however, is certain: the practices of Sufism and the worshipping at shrines have been controversial subjects in Islam - not only in the past but also in the contemporary Central Asian states: "They are often called 'un-Islamic innovations', or bid'ah, by those who now aspire to bring Islam in the region back to its 'true' roots in the tradition of Middle Eastern fundamentalist movements" (Schoeberlein 2009: 105). Among the critics of saints culture today are not only 'Wahhabis' and Salafis but also contemporary fundamentalists and educated modernist Muslims who consider it as superstition (Voll 2009: 220 ; 232). For example, during my visit to the region, I met members of the modernist Gülen movement as well as women from a private conservative praying circle who both expressed disagreement with folk religious practices in the same terms (I subsume under 'folk Islam' both, mazar worshipping and Sufism).

When we talk about the revival of Islam in Central Asia, we should first of all mention that after independence, folk Islam was able to regain its primary function and role in Central Asian society. Indeed, the great majority of devout Central Asian Muslims today do not belong to any of the (non-traditional) Salafi groups presented in chapter 3. The resurgence in popularity of pilgrimage sites such as the Mausoleum of Sufi leader Ahmad Yasawi in Turkestan attests to this. As Schoeberlein makes clear: "For many in Central Asia and neighboring regions, the activities associated with such holy places are the most prominent features of their everyday observance of Islam" (Schoeberlein 2009: 105). Kehl-Bodrogi, commenting

4 Examples of such persons are: Turajonzoda (Tajikistan), Kadyrow (Uzbekistan), Yusphon Shakirov (Kyrgyzstan) (Peyrouse 2007: 44). 
on the Khorezm region in Uzbekistan, reiterates this view: "[...] the most visible sign of a return to Islam in the public life is the increased popularity of local shrine pilgrimage" (Kehl-Bodrogi 2006: 239). In spite of this, it is difficult to ascertain how many people in Central Asia belong to the modern Sufi orders; how many are regular members (those that passed through an initiation process), and how many are mere sympathizers. The following PEW data regarding the percentage of Muslims who identify with Sufism is therefore of great interest to us - although it does not help us to distinguish between members of Sufi orders and mere sympathizers:

Figure 4: Percentages of Muslims Identifying with a Sufi Order

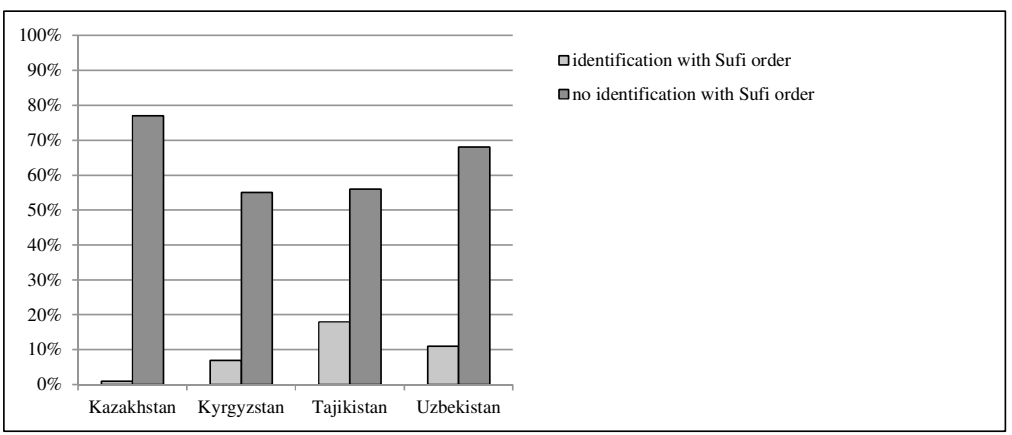

Source: PEW 2012

Figure 4 clearly demonstrates that notable minorities of Central Asian Muslims identify with one or another Sufi order. Furthermore, much higher percentages of Tajiks (18\%) and Uzbeks (11\%) identify with Sufi orders when compared with Kyrgyzs (7\%) and Kazakhs (1\%). The majority of Tajiks are thereby related to Naqshbandiyah (16\%), a minority to Khwajagan (a Shiite branch of the Naqshbandiyah) (PEW 2012: 114; 129). Many of the interviewees do not name a specific order but some Kyrgyzs say they identify with the Kubrawiya branch of Naqshbandiya and some Uzbeks and Kazakhs identify with the Yasawiya order (PEW 2012: 129).

In contrast to clearly defined Sufism, which has a strong hierarchical organization, in Central Asia the term 'folk Islam' refers to the incorporation of pre-Islamic behaviours into the Muslim faith in a popular form. Besides places connected to saints, in Central Asian folk Islam every cemetery and natural phenomenon can become a mazar; "a sacred place where people 
worship, pray and conduct different religious rituals" (Toktogulova 2007: 509). Such places often played already an important spiritual role in the pre-Islamic Shamanism that was prevalent in the region. There are two types of mazars in Kyrgyzstan (Aitpaeva 2007: 16):

- natural mazars: springs, mountains, forests, pits, stones, trees, lakes and so on.

- mazars created by humans: mausoleums of great people, ancient buildings, graves of people killed innocently.

Since independence mazar-worshipping has witnessed a real revival. According to the Aigine Research Institute in Kyrgyzstan, the growing religious consciousness of the population since independence can be seen at mazars, which are being visited and worshipped with increasing frequency (Aitpaeva 2007: 16). Baktykan, the shaykh who guards the holy site at Baytik Baatir's graveyard near Bishkek, explained that during the last decade increasing numbers of visitors came to this mazar (interview with Baktykan). The place was abandoned during Soviet times because at that time pilgrims were imprisoned or killed (interview with Baktykan). 
Image 1: Mosque at Baytik Baatir Mazar

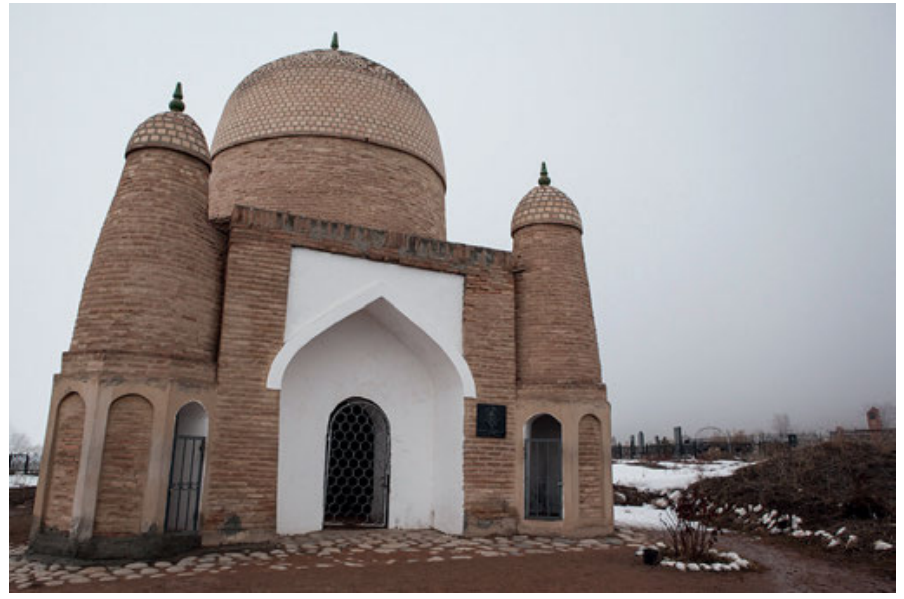

Source: Lisa Harand

Image 2: Gravestone of Baytik Baatir's Friend

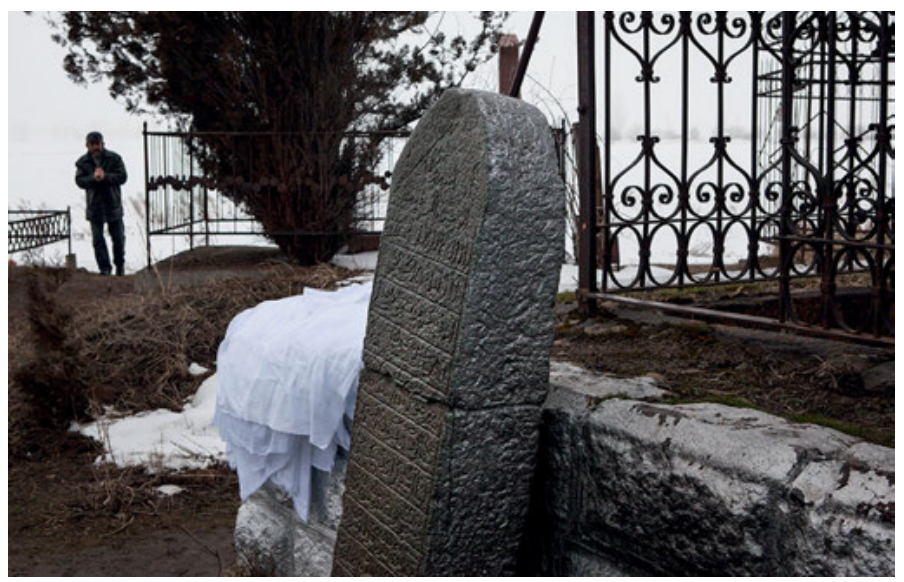

Source: Lisa Harand 


\section{Image 3: Shayk at Baytik Baatir Mazar}

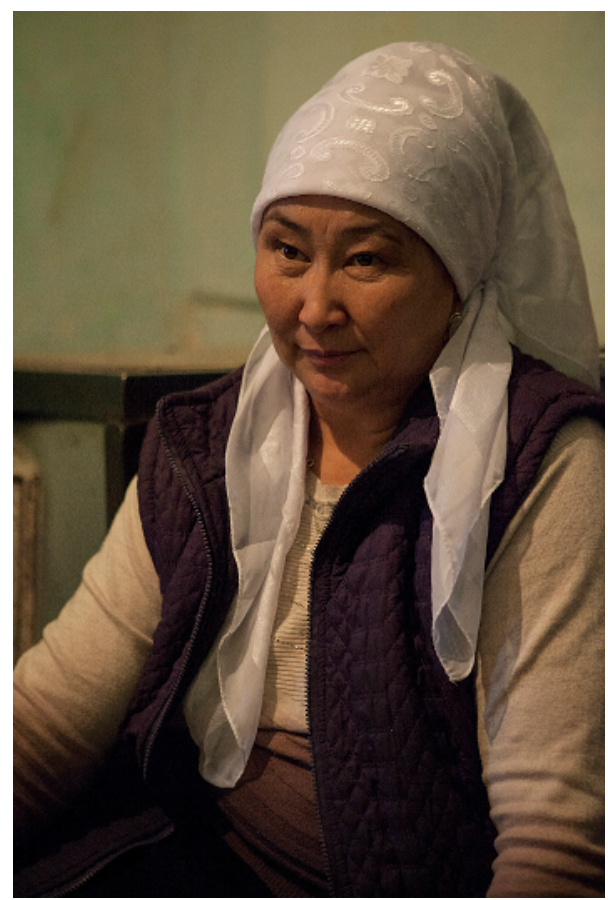

Source: Lisa Harand

Today, Central Asians visit holy shrines for many purposes as KehlBodrogi once again elaborates:

"Khorezmians share the belief common among many Muslims that saints are characterised by their closeness to God which enables them to serve as intermediaries in people's relation to God and to communicate His grace to the ordinary faithful" (Kehl-Bodrogi 2006: 240).

Among the visitors at Baytik Baatir's mausoleum are those who have physical diseases or women who cannot become pregnant. They tell their problems to the shaykh and afterwards receive instructions from her. Often she discovers how to cure people in her dreams. The 
shaykh's assistant explained to me that she has recently cured several women of epilepsy.

Religious practices at shrines are usually handed down from generation to generation (Louw 2007: 54). People visiting the small mosque of Baytik Baatir, built during his lifetime, start by bowing down three times in front of the steps which lead up to the building. After this they pray first in front of the building, then at his burial ground and finally at the graveyard of one of his closest friends. There is also a big stone with Arabic inscriptions on which believers stand and make a wish. The touching of a horseshoe in the same place is said to help one's wishes come true.

Apart from visitations of shrines, the invocation of ancestors' souls in order to pray for something is an important feature of Central Asian folk Islam. The graph below depicts the percentages of those who find such practices acceptable according to the Islamic faith. Furthermore, as traditional healing is closely interwoven with religious practices (as the aforementioned examples of Baktykan's spiritual healing power demonstrate), the percentage of Central Asian Muslims who visit traditional healers is also shown.

\section{Figure 5: Percentage of Muslims Supporting Folk Islam}

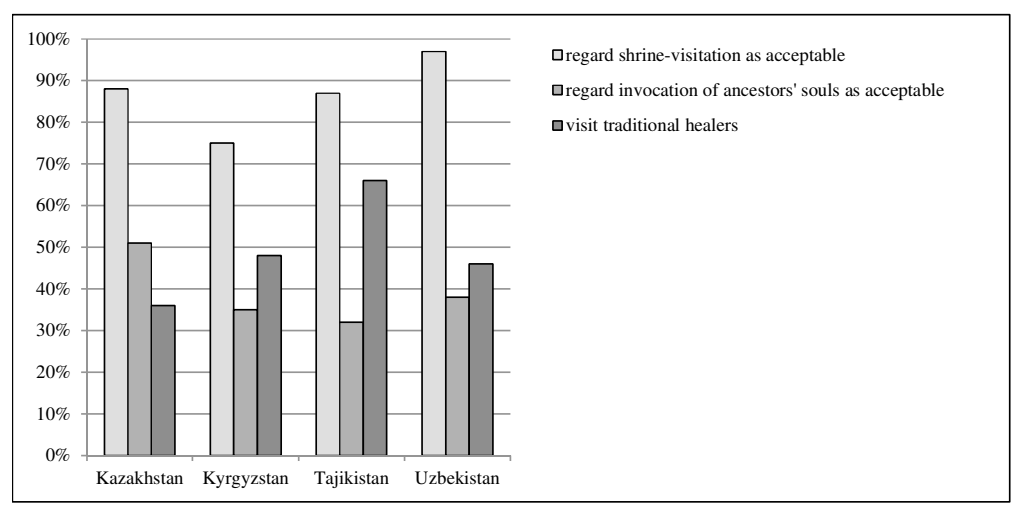

Source: PEW 2012

Whereas the vast majority of Muslims in all countries regard shrinevisitation as acceptable under Islam, the percentages of those who inter- 
pret the invocation of ancestors' souls as acceptable is a great deal smaller to the extent that it is a view shared by a majority (marginally over $50 \%$ or respondents) only in Kazakhstan. The reason why traditional healers are much more visited in Tajikistan than in the other countries could lie in the country's poor health services. However, this assumption cannot be proven with these data.

In summary, it can be said that, according to the PEW data, the majority of Central Asian Muslims deem traditional forms of practising Islam as acceptable. There are more adherents to folk Islam, which is understood to mean mazar-worshipping in general, as opposed to concrete memberships in Sufi orders, although Sufism plays an important role in Central Asian Islam, even today.

However, not everyone in Central Asia believes in such stories as mentioned by Baktykan or has respect for the practices contributing to them. Although it is popular, shrine culture has many critics even today. Among them are Salafis in particular but also educated modern Muslims who consider it a superstition to visit the shrines of dead people or natural phenomena (Voll 2009: 220, 232). Indeed, despite the omnipresence of sacred sites in Kyrgyzstan, such people deny their existence or describe them either as superstition or something so uncommon that it might only be prevalent in some very isolated part of the country (interview with a sympathizer of the Gülen movement; interview with the teacher of a private religious class). For them, praying at stones, springs and mountains, even if the prayers are directed to Allah, is especially sinful, because it disrespects God's oneness. 


\section{Salafi Isalm: Social Transformation and Political Islam}

Today, Islamic fundamentalists who intend to re-establish a Muslim society similar to that which existed during the life of the Prophet Muhammad are often referred to as Salafis. As Shahin explains, "[...] the salaf are the virtuous forefathers (al-salaf al-salih), and a salafi is one who draws on the Qur'an and the sunnah as the only sources for religious rulings" (Shahin 2009: 29). There are other terms such as 'Islamism,' 'Islamic radicalism,' 'Islamic fundamentalism' and many others that are used to describe the phenomenon of interest in this study. Whereas it is true that these terms are often used synonymously (Roy 2007: 59f), it is extremely important to clearly distinguish them in order to conduct a thorough analysis of the subject. I agree with other authors that it is better to speak of Salafis than of fundamentalists, because the latter is a western term. As this movement in itself is extremely broad I will first give some general notes on it: for example, it is worth pointing out that Salafis usually either refer to the Hanbali School of law or completely reject taqlid ('imitation') and thereby the affiliation to any madhab (Haykel 2009: 26). They are genuinely antiwestern but do not necessarily oppose modern education or political reforms, neither do they necessarily dismiss democracy outright. Furthermore, whereas all Salafis are anti-Sufi and oppose other Muslims, who they do not consider to be 'real' Muslims, not all of them try to convert them by violent means.

I focus here mainly on the following groups: The Islamic Movement of Uzbekistan (IMU), Hizb ut-Tahrir, Islamic Revival Party, Tablighi Jama'at, Fethullah Gülen Movement. Only the first one of these groups, the IMU, 
openly uses violent means - armed attacks and terrorist acts - in order to pursue its political goal of establishing of a caliphate. Although Hizb utTahrir shares this political objective, it argues that it does not resort to violent means. The Islamic Revival Party was part of the armed opposition during the Tajik civil war but abandoned fighting in the wake of the peace accords in 1997. Tablighi Jama'at is a neofundamentalist Islamic movement with many followers, particularly in Kazakhstan and Kyrgyzstan. The movement of Fetullah Gülen, which is totally peaceful, maintains schools in Central Asia which are supported by Turkish and local businessmen.

All these groups follow a very strict interpretation of Islam and are called Salafi here (I present a more detailed definition of such nontraditional groups in the typology of non-traditional Islamic groups in section 4.2). Some of them aim at establishing an Islamic society or an Islamic state while only IMU propagates violence against the Central Asian states, but all these groups are banned as extremist or terrorist organizations by at least one Central Asian state.

In the typology of state regulation of non-traditional groups (section 9.2) I will go into further details of how the Central Asian governments deal with these groups. First I will clear up the confusion surrounding some catchwords. Following this I will discuss the definitions of Salafism, Islamism and jihadism. This will be done with a comparison between definitions based on ideology and definitions based on the methods used for political struggle. Finally, I present the most important Islamic groups which aim at transforming Central Asian society into a particularly Islamic one or even hope to establish an Islamic state or caliphate and present my own typology of these Salafi groups.

\subsection{Catchwords, Misconceptions AND IMPORTANT TERMS}

In the current discourse on Islam in general and on 'political Islam' specifically, the terms sharia, jihad and terrorism are in common use. Political Islam is often reduced to a militant form of activism and its activists accused of illegitimate terrorism. We hear about radical groups who wage jihad against infidels or infidel rulers, and then 'establish' sharia after coming into power. But what do these terms signify exactly? It is indispensable to 
have a closer look at these catchwords because they are so broadly used (and misused) by mass media and politicians.

\subsubsection{Jihad}

In Central Asia, instead of jihad, the term ghazawat can also be used (Halbach 1989: 232). It refers to an Islamic doctrine "connoting an endeavour toward a praiseworthy aim" (Peters 2009: 252). Jihad has an important place in Islamic deontology (fiqh) (Halbach 1989: 216). The term can refer to different things, but in the context of Islamic law and in the Quran, it commonly means "an armed struggle against the unbelievers" (Peters 2009: 252). According to Peters its main classical functions are (Peters 2009: 254):

- motivation of Muslims to take part in war

- enhancement of legitimacy of a ruler or a movement

- law of war

In modern times, the doctrine of jihad developed different interpretations: there are conservatives, who stick to the classical legal interpretations, and there are radical Islamic opposition groups who try to gain influence by using the term in their own way (Peters 2009: 255). Of course, many have tried to appropriate the term for their own ends:

"Throughout Islamic history, governments and opposition movements have declared their Muslim adversaries to be heretics or unbelievers (takifr, declaring someone to be a kafir, unbeliever) in order to justify their struggle against them. This line of reasoning is used by contemporary radical Islamic groups to legitimate their use of arms against rulers who are to all appearances Muslims" (Peters 2009: 255).

An example of such a contemporary group is the Islamic Movement of Uzbekistan (IMU), which calls the President of Uzbekistan kafir, thereby denying his legitimacy as a ruler of Muslims and legitimizing the fight against him. Indeed, jihad organizations are generally defined as radical Islamic groups, using violent means for political actions (Peters 2009: 257). Although this is true, it is important to note that: 
"[...] automatically equating jihad to terrorism or to a kind of nihilism is largely incorrect. [...] Furthermore, the war they wage should not be considered as necessarily unjust simply because it is legitimized through a religious vocabulary" (Peters 2009: 257).

All too often, though, jihad is associated with an unjustly waged war, to the extent that the term is now often used to describe terrorist behaviour even though the concept has its origin in the wars Prophet Muhammad fought lawfully in response to aggression, and was originally not allowed to be applied against civilians, as Peters explains: "Ideas of chivalry forbade warriors from killing noncombatants, especially children, women, and old people (Peters 2009: 252). It is furthermore important to note that the term 'holy wars' typically refers to the Christian crusades, which do not have a counterpart in Islam (Halbach 1989: 216). In fact, as Halbach points out, the whole militant dimension of the term is exaggerated and its meaning should not be reduced to that of an expansionist war:

- Jihad has an internal and an external dimension and should therefore not be translated as war but as effort. Generally too much importance is attached to the external dimension and 'the fight against infidels'. By contrast, the internal dimension is the fight against apostasy and an effort for unity and solidarity in the Islamic community (Halbach 1989: 216).

- Jihad is usually justified if it is defensive, an expansionist jihad as a collective duty of Muslims is only legitimate if a caliph organizes the struggle (Peters 2009: 253).

To summarize, jihad can be waged not only against non-Muslims but also against nominal Muslims who are not believed to be practising the religion correctly. Furthermore, the term can be used to refer to a defensive war with legitimate grounds.

\subsubsection{Sharia and Fiqh}

In the context of Islamic radicalism we often hear that Islamists want to 'establish' sharia. The term sharia conjures horrific images for a westerner such as the stoning of innocent women or the chopping off of hands. It is 
therefore necessary to note that sharia is a positive condition in the Quran. Every Muslim has to follow the rules of sharia, by virtue of his belief, as it describes the "expression of Allah's command for Muslim society" (Encylopedia Britannica). The term means literally, "the path leading to the watering place" but in the western media and public a misconception prevails regarding it. As Roy makes clear:

"Here [in the debate on Sharia] total confusion rules. One can reject the Sharia as anachronistic and antifeminist, but in any event it is a legal system with norms and interpretations. Sharia is not by itself arbitrary, but defines a space of law [...] “ (Roy 2007: 74, translated by the author).

Sharia is therefore more to do with Islamic jurisprudence. In fact, the 'path' can only be totally known by God while the "human attempt to know the shari'a" is called fiqh (Rabb 2009: 255).

"In this sense, shari'ah is God's will expressed as an ideal reflecting perfect justice and equality. The human articulation of the ideal is a dynamic process that must constantly be worked and reworked to address new situations" (Rabb 2009: 255).

Sunnis derive fiqh from the four following sources of Islamic law:

- The Quran

- The Sunnah (prophetic practice and that of the imams)

- Consensus (ijma')

- Analogical reasoning (qiyas)

There is no scope to go into more detail here, however a final point worth mentioning is that contemporary groups often use the term merely for political purposes. They carry out 'jihad' in order to delimit themselves from the West (Roy 2007: 53). Yet it is not only Islamists who use jihad and sharia as catchwords in their propaganda; conservative counter-propagandists also avail themselves of these terms to conjure fears of an Islamic threat. 


\subsubsection{Terrorism}

Terrorism is a tactic of warfare and a communication strategy with a dual intention since the aim of a terrorist attack is often not only the victims themselves, who are also used to convey the terrorists' message (Girardin et al. 2002: 8). This message is directed towards two different types of recipients: the enemy (which might be the government or the whole population which the civilian victims are part of), who should be frightened by the attack, and sympathizers and supporters of the terrorists within their own ranks (Waldmann 2003: 88). Based on the analysis terroristisches Kalkül by Waldmann (Waldmann 2003: 88) I define terrorism as follows:

- Terrorism takes place as an act of violence against civilians.

- It aims at causing anxiety on the one hand and sympathy and malice on the other.

- It provokes political consequences.

With this definition I deliberately do not make a distinction between state and non-state actors. ${ }^{1}$ In my analysis, all actors should be analyzed and characterized using the same criteria. As civilians I consider persons who do not hold public office and do not take part in fighting. Politicians are not defined as civilians as they are representatives of the country they work for. People working in the security sector and military personnel are not considered civilians even in a situation where they do not wear their uniform or are not on duty (because non-state combatants are usually also regarded as

1 In this regard the definition used here differs to a great extent to terrorism definitions used by states. As an example, see the definition of the US Department of Defense: 'The term terrorism means premeditated, politically motivated violence perpetrated against noncombatant targets by subnational groups or clandestine agents, usually intended to influence an audience.' (DoD 2003: xii). Here the term noncombatant refers to civilians as well as to army personnel that are unarmed or not on duty during the time of the attack (PoGT 2003:xii). Although the definition of a civilian is different, the author of this study agrees with the US definition in that a terrorist attack has a political motivation and is directed against civilians. However, the restriction that all terrorist groups are nonstate actors is strictly disputed. 
combatants twenty-four hours a day). Attacks against politicians and military personnel are by this definition not acts of terrorism but acts of guerrilla fighting (which does not necessarily mean that these attacks are legitimate or do not in many cases violate international law).

Not only are terrorists usually considered criminals, but their political ambitions are also often rejected as unjustified. For this reason governments use this term to try to delegitimize the armed struggle of political opposition groups while at the same time resistance fighters try to prove the 'terror strategy' of the state to legitimate their resistance fight (Daase 2001: 55).

Physical violence is defined by Clausewitz as a means to force the enemy to do what one wants him to do (Clausewitz 1952: 90). Terrorism used by non-state actors is violence that is usually used against a much stronger force. In this sense, terrorism is an indirect and asymmetric strategy. The sixth century Chinese thinker Sun Tzu, as well as the Chinese revolutionary Mao Tse-tung wrote much about asymmetric strategy and how the weakness of an actor can be used as a strength (Stahel 2002: 2): Good knowledge of the terrain, for example, or the ability to move like a fish in the water, are advantages that terrorists as well as guerrilla fighters can make use of. Terrorist and guerrilla tactics seem to be quite similar because both of them use asymmetric strategies, however they are distinct: guerrilla tactics are used by separatist groups to fight against the military and police to gain control over territory whereas terrorists do not have territorial goals; instead they seek to wear the enemy down over a long time period by committing acts of violence against civilians thus forcing politicians to give in to their demands (Kuster 2006: 47). An example of a terrorist group in the region is the Islamic Movement of Uzbekistan (IMU), which has been declared a foreign terrorist organization by the US Center for Defense Information (CDI). The IMU is active in Uzbekistan, Kyrgyzstan, Tajikistan and Afghanistan and was accused of taking hostages on several occasions in 1999 and 2000, including four US citizens (see CDI).

In France, terror was employed by the Jacobins in 1789 as a systematic state programme known as 'régime de la terreur' (Al Treiki 2003: 30). State terrorism usually refers to abuses of power by governmental institutions against their own populations (Al Treiki 2003: 31). 20th century examples of terrorist states include the totalitarian regimes of Nazi Germany, fascist Italy and the USSR under Stalin. They used immense repression to bring 
about the total obedience of their peoples (Al Treiki 2003: 31). More recent examples of state terrorism might be Indonesia during the regime of Sukarno in 1965, Cambodia in the 1970s or North Korea under Kim Jong-il. Even though the governments of Uzbekistan, Kyrgyzstan, Kazakhstan and Tajikistan are seen as authoritarian by Islamist movements and human rights organizations, who accuse them of human rights abuses and repression against their own population, they are not terrorist states. Interestingly, Islamists also accuse some western powers - primarily the US and Israel of being terrorist states. As Bin Laden has argued: "The truth is that the whole Muslim world is the victim of international terrorism, engineered by America at the United Nations" (Bin Laden 1998).

\subsection{Political IsLam and SAlafism}

\subsubsection{Commonalities of Salafi Groups}

Salafis refer to the first three generations of Muslims which ended with the death of Ahmad ibn Hanbal 855 C.E.. All changes which influenced the faith after this point are considered un-Islamic innovations to the extent that the "Salafis claim to be members of the only victorious group that will be saved in the Hereafter" (Haykel 2009: 27). Fellow Muslims, as Haykel makes clear, can also therefore be considered infidels:

\footnotetext{
"The traditional targets of Salafi attacks are the Shi' ah, the Sufis, any persons who visit gravesites, and finally, followers of Ash'ari theology. [...] The recently more politicized Salafis have added to this list of enemies any Muslim who subscribes to modern ideologies such as nationalism, democracy, socialism, and more significantly any rulers, governments, or systems of rule that do not strictly apply Islamic law and teachings" (Haykel 2009: 27).
}

Whereas Salafis previously only opposed Central Asian folk Islam because the latter is so intimately interwoven with pre-Islamic traditions, they have only more recently accused the Central Asian rulers of being 'infidels' and therefore have added them to their list of enemies.

Salafi groups are united by a particular theology and a hermeneutics of scriptural sources (Haykel 2009: 28). More specifically, these groups' 
shared purpose is their commitment to particular theological doctrines that are associated with the pre-modern group known as the Ahl al-Hadith. According to Haykel this involves among other things:

- "a return to the authentic beliefs and practices of the first three 'generations' of Muslims [...]

- an emphasis on a particular understanding of tawhid (God's oneness), [...];

- claiming that the only valid sources of authority are the Qur'an and sunnah of the Prophet Muhammad [...] and the consensus of the Prophet's companions;

- arguing that a strict constructionist interpretation of the Qur'an and sunnah is sufficient to guide Muslims for all time and through all contingencies [...]" (Haykel 2009: 27)

Salafis do not have a sure footing in Central Asia: because of their wish to live a 'pure' Islam as did the first generation of Muslims, Salafis reject local traditions related to the practice of religion in Central Asia (in contrast to the traditionally strong Hanafi madhab, Salafis classically refer to Hanbali school of law; see Shahin 2009: 29). As with fundamentalists in other religions, Salafis distinguish themselves from other believers by their very strict interpretation of holy texts. By contrast, the written word is not of great importance to the average Central Asian Muslim, who is not used to read the Quran. Instead, being Muslim is connected to being part of a community that claims to have ancestral lines to the Prophet Mohammad (Khalid 2007: 19ff) (this is comparable to the importance of silsilahs for Sufism; see section 2.3.1). Schlageter expresses this observation even more radically:

„Many Muslims in Central Asia share a fundamental ignorance with regards to Islam. [...] The Qurans which were initially donated in large quantities by Saudi Arabia and Pakistan were ritual objects, used for marriages and national customs. Almost no-one can read them“" (Schlageter 2003: 165; 166, translated by the author).

PEW survey data about Quran reading confirms that Central Asians rather seldom read Quran (in many other regions such as in South Asia, Middle East and Africa around 50\% of all Muslims read Quran every day). How- 
ever, it would be wrong to call the Quran a mere 'Ritualobjekt' there: in Kyrgyzstan 18\% of the Muslims read the Quran every day and further 32\% read it at least once a week (PEW 2012: 50). This is the highest result for all Central Asians, which is interesting because traditionally Kazakhs and Kyrgyzs are said to be less 'scriptualist' than Tajiks and Uzbeks (see section 6.1.3 for this).

Figure 6: Quran Reading by Central Asian Muslims

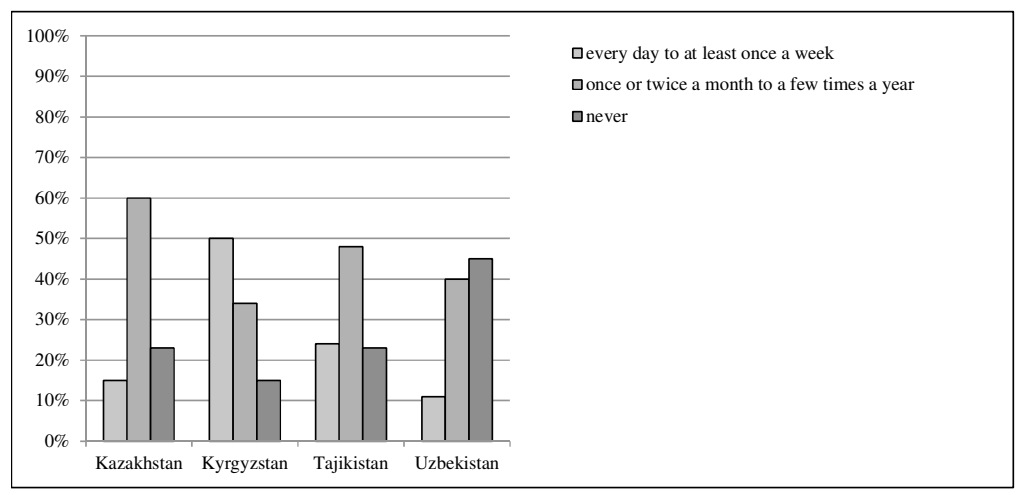

Source: PEW 2012

\subsubsection{Salafis in History}

Despite the aforementioned commonalities, the Salafi movements that existed at different points in time had more or less diverse (political) agendas. In the late $12^{\text {th }}$ century, for example, Salafis, "pointed to the 'adulteration' of Islam by various regional non-Islamic borrowings which they blamed for the political and economic decline of the Abbasid caliphate" (Yemelianova 2010: 13), while more recently they have combined anti-colonial, antiwestern and anti-Israeli messages and organized themselves into grassroots societies and political parties to proclaim their ideas (Yemelianova 2010: 14). Shahin distinguishes the following stages in Salafi history (Shahin 2009: 29ff):

- Classic Salafiyah, $8^{\text {th }}$ and $9^{\text {th }}$ century: Ibn Hanbal (founder of the Hanbali School of Law) "laid out the tenets that later shaped the Salafiyah" (Shahin 2009: 29). The classic Salafiyah emphasized the "primacy of 
the revealed text over reason," (see also section 5.1.2) set strict guidelines for the use of independent reasoning (ijtihad) and restricted the use of analogical reasoning (qiyas) (Shahin 2009: 29: 30). Later, (through the teachings of Taymiyah), the Salafiyah became anti-Sufi and anti-philosophical because they rejected philosophy owing to its Greek influence.

- Premodern Salafiyah, $18^{\text {th }}$ century: Muhammad ibn 'Abd al-Wahhab (1703 - 1792) referred to Ibn Hanbal's and Ibn Taymiyah's teachings and aimed at purifying the "Arabian Peninsula from un-Islamic practices and build[ing] an Islamic state modelled on that founded by the Prophet" (Shahin 2009: 30). Later Wahhabi movements also "advocated religious purification, moral and social reform” (Shahin 2009: 30). The contemporary (mis-) use of the term Wahhabi has already been noted in section 2.2.3).

- Modern Salafiyah, turn of the $20^{\text {th }}$ century: their main representatives are Jamal al-Din al-Afghani and Muhammad 'Abduh. During their time, the movement was characterized by its, "essentially intellectual and modernist nature and by the diversity and expanse of its objectives" Shahin 2009: 30). These features of the modern Salafiyah are similar to those of the Jadidis (see section 5.2.2) in that they regarded education and political reform as essential. Furthermore, they were the forerunners of contemporary pro-democratic Islamist parties like the IRPT (see section 3.4.2) because as Shahin makes clear:

"Many reformist intellectuals attempted to reformulate Islamic concepts in the light of modern political ideals and practices. They reinterpreted such concepts as shura (counsel) and ijma' (consensus) and equated them with democracy and a parliamentary system. In practice, they called for gradually increasing representation in administrative and political institutions" (Shahin 2009: 32).

The modern Salafiyah regarded autocratic rulers and despotism as the main stumbling blocks for progress in Islamic societies. Their movement developed in the context of confrontation with western colonialism: "the Salafiyah worked to assert the validity of Islam in premodern times and to prove its compatibility with reason and science" (Shahin 2009: 31). They were anti-colonialist and nationalistic in a pan-Islamic regard (Shahin 2009: 33). As with the contemporary Gülen movement 
(see section 3.5.1), their approach revived the original Qur'anic message but also offered an alternative "to the literalism of traditionalist interpretations" (Shahin 2009: 31). I will come back to the here mentioned present-day groups later on.

- Modern Islamic Movements: $20^{\text {th }}$ century. Modern Islamic Movements such as Hasan al-Banna's (1909-1949) Muslim Brothers (Egypt) and Abu al-A'la Mawdudi's (1903-1979) Jama'at-i Islami (on the Indian subcontinent), both of which developed in the 1930s, are regarded as heavily influenced by the historical Salafis. In contrast to the modern Salafis, they did not support legal, political and educational reforms, but were instead populist in approach and "focused on reforming the morality and beliefs of the Muslim individual as a precondition for the reform of the society as a whole" (Shahin 2009: 34). It is my view that presentday groups such as Tablighi Jama'at share the following features with the Muslim Brothers and Jama'at-i Islami: "strict monotheism, divine attributes, purifying Islam from accretions, anti-Sufism, and developing the moral integrity of the individual" (Shahin 2009: 34). I will refer to such present-day groups later on as fundamentalist Salafis.

Although all Salafis share the common aim of establishing an Islamic society, uniting all Muslims and living according to the Quran and the Sunnah, the measures to realize this ideal distinguishes them, as Haykel asserts, "Salafi groups are numerous and often in contestation with each other, especially over matters of political action and the means of effecting reform of Muslim society" (Haykel 2009: 28). In the literature and, by extension, in political practice, different classifications of contemporary Salafi groups have been developed. Some are based on their underlying ideology and others are based on their tactics and behaviour. The following section gives some examples of such definitions.

\subsubsection{Different Definitions of Political Islam}

Olivier Roy, the renowned expert on political Islam and terrorism makes a distinction between neofundamentalists, who aim at Islamizing society from the bottom up, and Islamists, who want to seize political power to transform society from the top down. He moreover characterizes the 
neofundamentalists as cut off from tradition and local culture and as being therefore a symptom of globalization (Roy 2007):

"Modern Salafism is both the consequence as well as the driving force of deculturalization. In no way is it the reaction of a traditional society which rejects modernization" (Roy 2007: 77).

As was already briefly mentioned in section 2.4 on folk Islam, traditional understandings of religion and their commingling with pre-Islamic religious rituals are regarded by moden Salafi movements as highly superstitious and sinful.

Although they aim to establish an Islamic state, Roy considers neofundamentalists to be primarily religious. As he explains, in their eyes, the state can solely declare Sharia the law of the land, but above that it cannot enact any laws (Roy 2007: 74). In his view, then, neofundamentalists regard sharia as the key to society and their only political concept. Islamists on the other hand, regard Islam as a political ideology from which many different political claims are derived (Roy 2010: 53). According to Roy, Neofundamentalists are primarily successful in rural areas, whereas Islamists (whom he describes as primarily political) tend to find more support in cities (Roy 2010: 53). I find it difficult to confirm this view, though, as corresponding data are not available.

Considering the same factors which affect contemporary developments in the realm of Islam, which Roy refers to as globalisation, Khalid argues that mass education and modern media call traditional authorities into question. Modernization has had an 'objectifying' impact on religion in general and on Islam in particular (Khalid 2007:12). In accordance with Roy he alludes to Islamists as having a political ideology that derives political goals and a need for action directly from the written sources of Islam (Khalid 2007: 13). They do not only appeal to a new political order but, as with the $20^{\text {th }}$ Century Islamic movements mentioned earlier, also to the transformation of the individual (Khalid 2007: 14). It seems that he would also agree with Roy on the question of whether Islamists are de-territorialized and de-culturalized, as he goes on to say: "Islamism is modern in that it presupposes the objectification of Islam, for only when Islam is separated from custom, tradition, and indeed history can it become a stand-alone object that can in turn be applied to the practice of politics" (Khalid 2007: 13). 
As we see, in many regards Roy and Khalid are in agreement. One key difference between the two theorists, though, is that whereas Roy uses the term 'fundamentalists' for groups such as Al-Qaida, Khalid defines this group, as well as the Islamic Movement of Uzbekistan (IMU), as jihadist, as the following passage demonstrates:

"These groups [IMU, Al-Qaida] differ from Islamists, because they have little or no political program beyond the conquest of power and the subsequent imposition of the shariat as the law of the land. They interpret jihad in a purely military sense, and unlike the Islamists, have no interest in the transformation of society beyond policing norms of behaviour" (Khalid 2007: 19).

He explains that jihadism arose in the context of the Soviet invasion in Afghanistan and the Islamic Revolution in Iran when Saudi Arabia, Pakistan and the US supported the Northern Alliance in Afghanistan (Khalid 2007: 16, 17). A further category that Khalid discerns are the modernists: these argue that Islam calls on its adherents to be progressive and they therefore challenge ulama and Sufi shayks, accusing them of corrupting religion (Khalid 2007: 13).

Similar to Khalid, Haykel distinguishes groups according to the form of political engagement they advocate and therefore distinguishes between political and jihadist Salafis:

- Those calling for violent action are called jihadis

- Those engaging in nonviolent political activism are harakis

Furthermore, he adds a group of Salafis who deny all forms of political organization and action are therefore are called quietist taqlidis. They argue that "obedience to Muslim rulers is religiously mandated" (Haykel 2009: 26). Another author, who distinguishes Islamists based on their behaviour and tactics is Hafez:

"By moderates I mean those individuals and groups that shun violence and insurgency as a strategy to effect social change and, instead, seek to work through state institutions, civic associations, or nonviolent organizations to Islamize society and politics. Conversely, radicals are those who reject accommodation with the state re- 
gime, refuse to participate in its institutions, and insist on the necessity of violent revolution or mass mobilization to Islamize society and politics" (Hafez 2003: 5).

A final ideology-based definition worth mentioning in the specific context of Central Asia is that made by Peyrouse, who distinguishes between conservative Hanafis and fundamentalist Hanbalis. At the vanguard of the latter he names Ziyauddin Babakhan, who was the supreme mufti of SADUM during Soviet times and whose family led this institution for three generations.

All these definitions incorporate important aspects (distinction of means used by a group, the priority given to religion over politics or vice versa and the character of the movement: progressive or backward-looking). However, since no generally accepted terms yet exist, I will elaborate my own definitions for the main groups that are active in Central Asia. I will now introduce the most prominent non-traditional religious groups active in the region and subsequently elaborate my own typology for categorizing them in chapter 4 .

\subsection{JIHADISTS: ARMED WARRIORS FOR the CALIPhAte}

Islamic Terrorism is here understood as attacks against civilian targets perpetrated by jihadists. Furthermore, the establishment of an Islamic state with the introduction of sharia as the law of the land would be jihadists' primary and most fundamental political act when establishing an Islamic state. PEW survey data regarding attitudes of Central Asian populations towards Islamist terrorist acts are therefore of great interest to us. Figure 7 shows how the level of acceptance is proportional to the wish of Muslims to introduce sharia as the law of the land. I consider the level of support for both issues surprisingly high for a region that is very often described as only superficially Muslim or where most of the people regard themselves only as 'ethnic Muslims'. 
Figure 7: Approval for Terrorist Attacks Compared to Support for Sharia

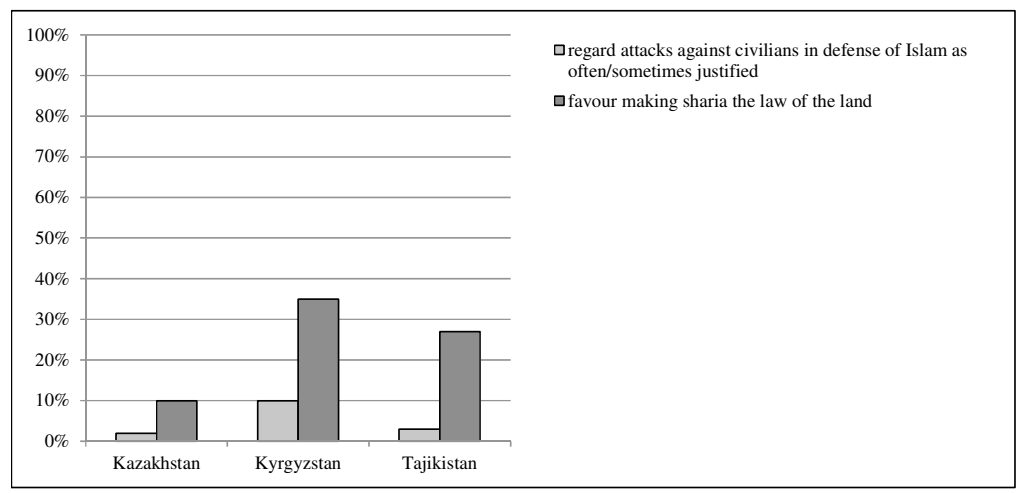

Source: PEW 2013

Recently there have been many reports by Central Asian online media on individuals from the region who have gone to Syria in order to fight there alongside local jihadis. This is comparable to Chechens and Arabs who fought alongside the Taliban and Al-Qaida in the 1990s in Afghanistan. However, despite the existence of a global network of jihadis, these affiliated groups do not belong to a single homogenous tradition. In other words, although Central Asian Muslims are influenced by globally agitating Islamic networks there is no 'Islamic Mastermind' responsible for coordinating jihad-networks in the CIS-countries (Halbach 2010a: 86). In order to qualify this statement I will now present the Islamic Movement of Uzbekistan and its successor organizations.

\subsubsection{Islamic Movement of Uzbekistan and Islamic Jihad Union}

After the collapse of the Soviet Union, several Islamist groups emerged in the Ferghana Valley. Voluntary militia and patrol units were active in the Uzbek cities Namangan, Andijan and Kokand, and groups such as Adolat, Islam Lashkarlari and Tawba even established control over mosques and government buildings (Khamidov 2009: 153). Those in charge of these groups went on to become leaders of the Islamic Movement of Uzbekistan (IMU) (Naumkin 2005: 96). The governmental policy towards these precursors to the IMU changed over time: 
"Initially, President Karimov maintained dialogue with Islamic organizations, deferring some powers of the local governments to them. This allowed the authorities time to focus on bolstering the security structures - the army, police, and national security service (the successor to the KGB). By 1993, the Uzbek authorities began to renege on their prior agreements with the Islamists and launched a frontal attack on them" (Khamidov 2009: 153).

Subsequently, hundreds of them were jailed or fled the country to Tajikistan and Afghanistan, where they continued fighting. In Tajikistan "Ethnic Uzbek Islamist fighters led by Namangani and Yuldashev fought alongside the United Tajik Opposition (UTO) in the Tajik Civil War (1992- 1997)" but were obliged to leave the country after the Tajik government and UTO peace accords had been signed (Khamidov 2009: 153). Namangani and Yuldashev, however, refused to comply with the Tajik government's demands and fled with their combatants to the Garm Valley, which became their stronghold in the late 1990s (Khamidov 2009: 153). In 1998 they founded the Islamic Movement of Uzbekistan (IMU), (in Russian IDU for Islamskoe Dvijeniie Uzbekistana).

Ideologically, the IMU is influenced by Salafism but it has always avoided being directly linked with a particular group of Sunnism in order not to alienate itself from supporters of different schools of thought (Khazanov 2005: 33). Due to its legitimation of violence, the movement can clearly be characterized as a jihadist organization since fighting is one of its main reasons to exist, as Salmorbekova and Yemelianova make clear: "Unlike the Islam Lashkarlari, the Adolat and Tawba, the IDU [= IMU] prioritized political and military engagement rather than religious education and indoctrination" (Salmorbekova and Yemelianova 2010: 222). Indeed, the group is so committed to armed struggle that it has almost become apolitical:

"These groups [Al Qaida, IMU] differ from Islamists, because they have little or no political program beyond the conquest of power and the subsequent imposition of the shariat as the law of the land. They interpret jihad in a purely military sense, and unlike the Islamists, have no interest in the transformation of society beyond policing norms of behaviour" (Khalid 2007: 19). 
Or, as Roy puts it:

"Like all neofundamentalists the group is primarily religious and not political, as they are not really interested in the state, the nation or the establishment of political institutions but just aim at the strict implementation of Sharia (Roy 2007: 68; 107)."

Some governments say that the IMU widened its scope in 2004 to the whole of Central Asia and Xingjiang and has since renamed itself the Islamic Movement of Turkestan (IMT). Members of the IMU, however, have denied this claim (Khamidov 2009: 155). A real successor organization of the IMU is the Islamic Jihad Union (IJU), which was responsible for acts of terrorism 2004 in Tashkent and 2009 in Andijan (interview with Ponomarev).

\subsubsection{Caucasus Factor}

One reason why particularly the "oil-rich west" of Kazakhstan has been the victim of terrorism more recently could be due to "social tension and dissatisfaction at inequality and living standards" (Lillis 2011). During my field work in Central Asia I learnt from OSCE staff members about the influence of Caucasian radical groups in the region and in Kazakhstan specifically. It is interesting to mention this connection because the link between Central Asian jihadists and Afghanistan is much more prominently reported in the literature. $^{2}$ The relationship to the Caucasus suggests itself, though, as Chechnya and Dagestan are historically (and in some parts also geographically) much closer to Central Asia than Afghanistan. Indeed, this is also true to a special extent for western Kazakhstan not least because of the rather high percentage of ethnic Chechens living in Kazakhstan as a result of Stalin's deportation policies who today still maintain family ties to their relatives in Chechnya.

According to my interview-partners (interviews with members of OSCE Units in Almaty and Bishkek), groups affected by the Chechen civil war

2 Police shootings and suicide bombings in Atyrau, Taraz and Boraldai (near Almaty) in 2011 were reportedly executed by Jund al-Khilafah (JaK), a Central Asian groups of jihadis fighting in the Afghan-Pakistan border area against international troops (Zenn 2013). 
primarily target security forces. The actions of such groups can be characterized as clearly political statements. For example, in May 2011, a man executed a suicide attack in Aktobe in north-western Kazakhstan against the KNB security services (Lillis 2011). ${ }^{3}$

As the following report shows, though, these Caucasian radicals do not appear to be entering Kazakhstan to wage jihad there. On the contrary, it appears to be the Kazakhs who are leaving their country to join their cofighters in Dagestan:

"In October 2010 Russian police shot dead a Kazakh citizen from Aktau who they said was an extremist holed up in an apartment in the Caucasus republic of Dagestan, [...] In July 2009 five alleged militants carrying Kazakh passports were shot dead in Dagestan, and this [2011] February two alleged extremists from Kazakhstan surrendered to police in Dagestan [...]" (Lillis 2011).

More evidence of this view is provided by Vitaly Ponomarev from the Memorial Human Rights Center who judges that there are no Caucasians coming to Kazakhstan to take up armed struggle but rather the other way round. The detentions of Kazakhs abroad, reported by Lillis above, concurs with this assessment. Furthermore, the many reports about Central Asians leaving for Syria during 2013 also indicate that international jihadis do not come to Central Asia to fight but rather that Central Asians prefer to join jihad elsewhere. ${ }^{4}$ This, however, could change of course if a more severe conflict between violent Islamists and Central Asian governments were to develop. Other reports about Kazakhstan and Kyrgyzstan claim that a new IMU is forming itself with recruits from Chinese Autonomous Uighur province as well as with "militants from Caucasus and other Russian regions" (Seisenbekova 2011b).

3 He was described by the security services as a criminal and not an Islamist, though.

4 See for example the following news articles: www.centrasia.ru/newsA.php?st= 1387878900; www.centrasia.ru/newsA.php?st=1384942260; http://rus.azattyk. org/content/kyrgyzstan-syria-suzak-jihad/25176282.html. 
However, the facts for confirming such speculations are rather vague and the conflation of IMU with HT detracts from the reliability of the report. In any case, the fact that international relationships between militant organizations exist is a concern for both Central Asian governments and societies. 


\subsection{Islamists: Political Parties}

The Central Asian states are corrupt, their economic situation is dire and traditional societal structures are disintegrating due to growing urbanization and high percentages of migrant workers abroad. In this context, Islamists argue that the poor economic situation and the rampant corruption could be solved if the society and the state followed the rules of social justice deriving from the Quran. Islamists refer to the ideal of an austere ruler (Matveeva 2010: 36) and make reference to moral guidelines grounded in Islamic principles which would solve society's problems (Murzakulova and Schoeberlein 2010: 156). In addition, the official clergy is ill-equipped to deal with the difficult socio-economic situation in Central Asia, paying little attention to people's sorrows:

"Theological incompetence, corruption and the pro-government position of many registered Muslim clergy, as well as their avoidance of a debate with Islamists on vital socio-economic political and ideological issues, undermined public trust in them" (Salmorbekova and Yemelianova 2010: 237; see also Halbach 2010a: 84).

The data presented in Figure 8 show the opinions of Central Asian Muslims concerning the political influence of religious leaders and their attitude toward religious parties (there are no data available for Uzbekistan).

Figure 8: Attitudes towards Political Islam among Central Asian Muslims

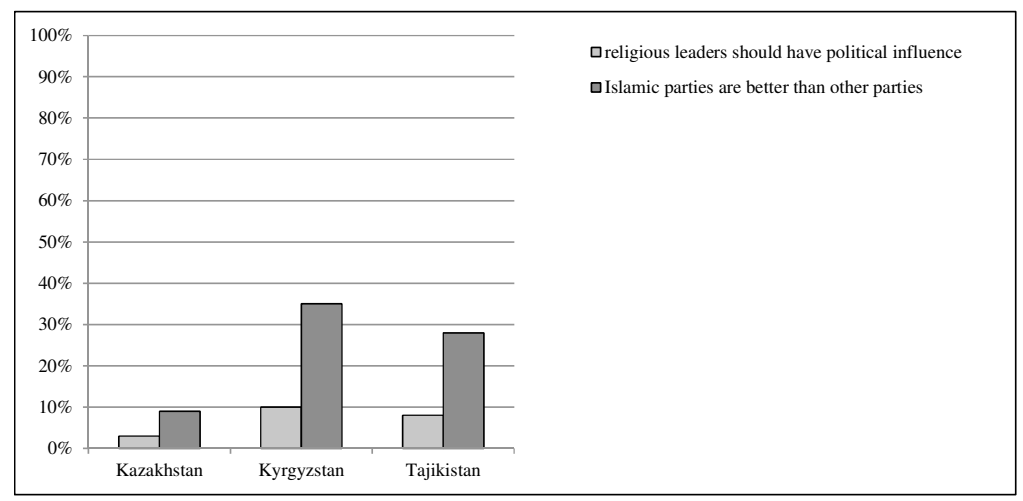

Source: PEW 2013 
In this section I will present some political parties or groups who take these concerns seriously and who use Islam as a basis for their political ideology. First of all, Hizb ut-Tahrir will be characterized. After that, the Islamic Renaissance Party of Tajikistan (IRPT), the only institutionalized religious party in Central Asia, will be presented.

\subsubsection{Hizb ut-Tahrir}

Hizb ut-Tahrir (HT) was founded in Jerusalem in 1953 by Taqi al-Din alNabhani (1909-1977), who had links to the Muslim brotherhood; currently the best known Salafi group, the brotherhood has its origins in Egypt in 1928. HT has since its very beginning maintained its ideological and operational cohesion (Taji-Farouki 2009: 423, 425), as Karagiannis explains:

"Hizb ut-Tahrir's consistency is associated with a dogmatic and consistent implementation of its ideology, which envisions a peaceful overthrow of the existing regimes in Muslim countries" (Karagiannis 2010: 48).

Despite its political goal, which is to establish a caliphate, this transnational movement differs from jihadi groups in that it can be regarded as a purely political party which is conceptualized and organized in a modern way (Khalid 2007: 160; Roy 2004: 67). It also regards itself not as a religious organization but as a political party that draws its legitimacy from Quranic sources (Karagiannis 2010: 40).

Hizb ut-Tahrir has been increasing its influence in Central Asia since the mid-1990s and has a considerable membership there (Taji-Farouki 2009: 423). At first glance, this is surprising since it emphasizes the unity of the ummah whose concomitant denigration of national peculiarities seems to contradict the regional understanding of the nation as well as of religion and Islam in particular (Khalid 2007: 162). However, as Khalid explains, although they have transnational links, the political Islamist groups in Central Asia (IRPT, HT and IMU):

“[...] have roots in domestic political realities and focus primarily on local issues. They are not implantations of a global Islamist movement with a monolithic agenda. [...] [but] represent forms of homegrown opposition to the political order" (Khalid 2007: 164). 
In Khalid's opinion, the success of HT is understandable because it ties in with the populations' dissatisfaction with the political and moral order in the region; it stands for the fight against corruption and the abolition of the recently established borders between the former Soviet republics (Khalid 2007: 163f). With their agenda, the party was able, “[...] to respond effectively to the ideological vacuum created by the collapse of Communism and problems of socioeconomic deterioration" (Taji-Farouki 2009: 424). When they claim that they can provide better security, growth and welfare than a secular state, their advantage is that they seem credible since they are God-fearing and therefore should not be corruptible (Matveeva 2010: 19). HT's political aim is to build a modern welfare state (Khalid 2007: 161). With their reference to the Quran, the party constructs Islam as an ideology that is superior to capitalism and socialism: it emphasizes justice and inclusion and criticizes the neo-colonial exploitation by global western hegemony (Taji-Farouki 2009: 424). Its political agenda has a clear goal: the reestablishment of the caliphate and a Pan-Islamic state. Hizb ut-Tahrir sees the Quran as "the only acceptable source of political thought; the ummah constitutes a unitary entity and the caliph symbolizes its political cohesion" (Karagiannis 2010: 94). The party's historical narrative and its reference to the caliphate must be understood in terms of its original contraposition "to secular Pan-Arabism in the struggle to reverse the fragmentation caused by the implantation of nation-states and Israel" (Taji-Farouki 2009: 424). It interprets nationalism as a western innovation and regards the borders between Muslim countries as artificial creations (Karagiannis 2010: 42). This makes the party especially popular in the Ferghana Valley with its arbitrary demarcations. According to Naumkin, the party changed its focus in Uzbekistan in the wake of the Andijan events 2005. It started to criticize the government by

„,...] addressing the daily needs of the population. This is in marked contrast to previous publications, in which the HT paid much attention to Middle Eastern problems, such a support for the Palestinians and criticism of Zionism" (Naumkin 2005: 164).

More generally, the party's leaflets criticize local governments and also contain anti-American, anti-western, and anti-capitalist propaganda (Khamidov 2009: 155). 
Interestingly, HT does affiliate members from different madhabs, as the party itself points out:

"The party $[\ldots]$ invites all Muslims to carry Islam and adopt its systems regardless of their nationalities, colours and madhahib (Schools of Thought), as it looks to all of them according to the viewpoint of Islam" (HT).

In the eyes of Naumkin, this openness is tactical since it enables HT to build on its transnational status and gain supporters from different strands of Islam. As he explains, "a number of researchers believe that Nabhani was an adherent of Hanbalism on questions of law, rejecting in particular the tribal laws" (urf and adat) (Naumkin 2005: 135). Yet even if we assume this to be true, today they do not preach the idea of takfir nor are they fixed on bid'a, which would be typical for Salafis (Naumkin 2005: 145). Indeed, according to Salmorbekova and Yemelianova, HT should be classified as a moderate Salafi group:

"It should be noted that compared to other Salafis, and especially Wahhabis in the North Caucasus, who have treated the local Islamic traditions as bid'a (sinful innovation), Tahriris have attuned their $d a$ 'wa to local 'folk' Islamic traditions. They have been respectful of local 'urf and 'adat norms and appreciative of regional Hanafi Islam. They have also been more cautious in applying the concept of kurf (non-belief) in relation to the actions and policies of local and national government officials" (Salmorbekova and Yemelianova 2010: 224).

Apart from its moderateness, HT also differs from other Salafi groups in the political measures it propagates. Although it does not participate in democratic processes, neither does it directly advocate armed jihad for establishing the caliphate. According to some authors, it is even open to dialogue with Central Asian governments (see Salmorbekova and Yemelianova 2010: 224; Naumkin 2005: 146). For the moment, it only considers armed jihad as an option for defence (Roy 2004: 255). The party is therefore not classified as a jihadist organization (Salmorbekova and Yemelianova 2010: 224). Yet, if Hizb ut-Tahrir's “position against the launching of jihad is purely tactical" (Roy 2004: 256), and justifies jihad at a later stage, this means that it cannot be called strictly non-jihadist either (Naum- 
kin 2005: 145). This is why I classify the party here as non-violent but potentially jihadist.

What we know for certain is that Central Asian governments are concerned by the party's activities in their countries and have banned it as an extremist or terrorist organization. Indeed, even though it claims to use only peaceful means "[...] the governments of Uzbekistan and Kyrgyzstan have blamed it (without convincing proof) for various violent acts on their territory" (Khalid 2007: 161). Since the Andijan events in Uzbekistan in 2005, the Central Asian governments have intensified their repression of HT and other Islamist groups (Salmorbekova and Yemelianova 2010: 225).

Despite the big differences in relation to the means used for their political struggle, apart from their common goal (an Islamic caliphate), there is evidence of personal links between members of the IMU and Hizb utTahrir. For example, former HT members from Central Asia fled to Afghanistan in the late 1990s and joined the IMU ranks there (Khamidov 2009: 155). Furthermore, "the IMU has supposedly used HT literature to teach its illiterate members to read" (Khamidov 2009: 155). Despite these connections, I assume that in addition to the question of violence, the following differences speak for a clear distinction between them:

- The IMU has a predominantly national agenda, its most important goal being the overthrow of the Karimov regime, whereas the HT is a large transnational movement.

- The IMU pays money to its members for their membership in contrast to HT, which concentrates its efforts on convincing members to join their group with leaflets and books (Khamidov 2009: 155).

- The fees that party members pay to HT are its main source of income, whereas the IMU is involved in criminal activities such as drug trafficking and hostage taking (Salmorbekova and Yemelianova 2010: 222).

While the non-violent HT shares the goal of establishing a caliphate with IMU, the Islamic Revival Party, which I will introduce next, would be compatible with democracy, although it once was an armed conflict party in the Tajik civil war. 


\subsubsection{Islamic Renaissance Party}

At the June 1990 Congress of Muslims in the USSR, the Islamic Renaissance Party (IRP) was legally founded as a pan-Soviet political party with a religious foundation. Already during its foundation, the IRP was criticized by young Salafi revivalists, who took issue with it because it did not strive for an Islamic state (Naumkin 2005: 57). With regard to its ideology, the party therefore can be classified as moderate Islamist (compared to the HT's goal of an Islamic caliphate). After independence, however, the Party was outlawed in all Central Asian countries, as Naby explains:

"The IRP- $[\ldots]$ languished in the tribally organized and more superficially Islamized parts of Central Asia (Kazakhstan, Kyrgyzstan, and Turkmenistan) while it competed for political power in Uzbekistan and Tajikistan” (Naby 2009: 157).

In Tajikistan, it became part of the opposition during the civil war from 1992-1997. In the peace accords, it gained a 30\% share of parliamentary seats and was promised some ministerial posts. Since then, Tajikistan is the only Central Asian country in which a religious party can participate legally in the political process (in all other countries the existence of religious parties is forbidden). It is therefore worth taking a closer look at this party and how it gained its share of governmental power.

It is debatable whether the Tajik civil war should be considered first and foremost as a war between secular ex-communists and Islamists or, rather, a "struggle of regional factions that for various reasons had chosen different political orientations and ideological garments" (Khazanov 2005: 30). In fact, the members of the IRPT primarily stemmed from the Gharm and Karategin regions, while the ex-communists gained support from Russia and Uzbekistan and mainly had members from the Kuiab, Khujant and Gissar provinces (Khazanov 2005: 30). In any case, the United Tajik Opposition (UTO) was principally made up of Islamists, with Democrats playing a merely supportive role.

During the civil war, the IRPT fought for an Islamic state but transformed itself into a modern political party after the peace agreement so that it is now compatible with democracy and comparable to the Turkish Justice and Development Party (Karagiannis 1997: 97). The IRPT participated in the 1999, 2005 and 2010 elections but boycotted the November 2006 presi- 
dential election (Naby 2009: 158). In the 2013 presidential elections the IRPT supported a female secularist human rights lawyer as a challenger for Rahmon (Najibullah 2013). However, according to Naby, the "establishment of an Islamic society" remains "the ultimate goal of the IRP [...]" (Naby 2009: 158). The party has the following three fundamental objectives: spiritual revival, economic freedom and the "political and legal awakening of Muslims with the aim of activating in everyday life the basics of the Qur'an and the sunnah" (Naby 2009: 158). In this regard, the party is a typical Islamist party. It mainly represents Hanafi madhab but claims to have members from all over Tajikistan, among them even Ismailis (interview with Kabiri). The party brings together members with more and less radical ideas, which has given rise to factions (Naumkin 2005). Salafi elements in the IRPT, for example, condemn Novruz celebrations or the visiting of mazars and oppose the organization of expensive funerals (interview with researcher for Alert International).

\section{Image 4: Meeting at the IRPT Headquarter in Dushanbe}

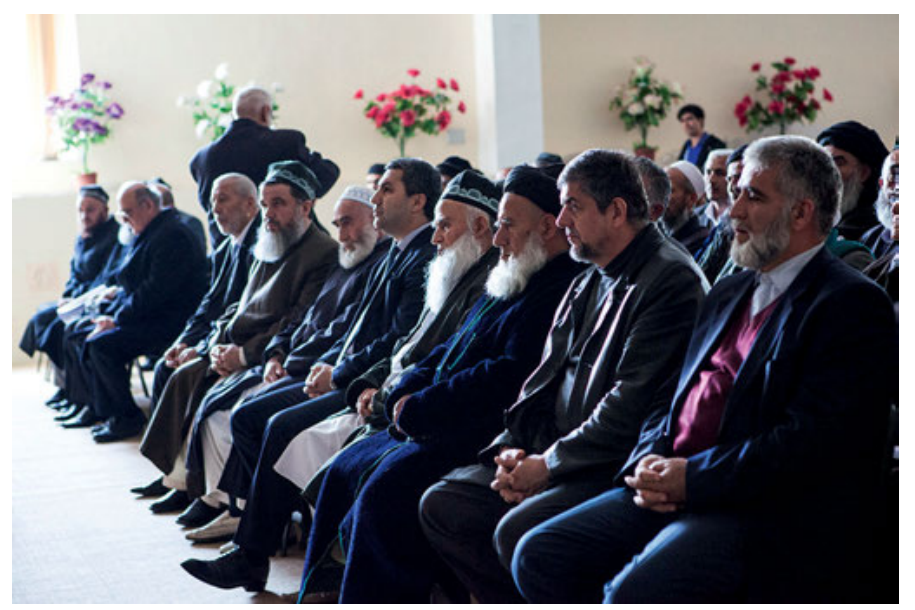

Source: Lisa Harand

The IRP members see themselves as reformists who combine antiimperialism against the West and Russia with progressive ideas for the improvement of society and Islam as the route to socio-political development (Naby 2009: 158): 
"The thirty-two-point agenda of the IRP stresses moral interpersonal actions, the defense of Islam against the accretion of any 'ignorant contemporary' (i.e., nonIslamic) doctrine, and the resolution of disputes through the Qur'an and sunnah. In addition, the agenda supports the promotion of sports and health programs, provision of welfare for the needy, private ownership of property, and support of ecological activity" (Naby 2009: 158).

However, when asked what he would change first, if he had the opportunity, Kabirir, the president of the party, responded that he would a) hold free elections; b) fight corruption; and c) allow for more religious freedom in the country (interview with Kabiri).

\section{Image 5: Kabiri, President of the IRPT (Dushanbe)}

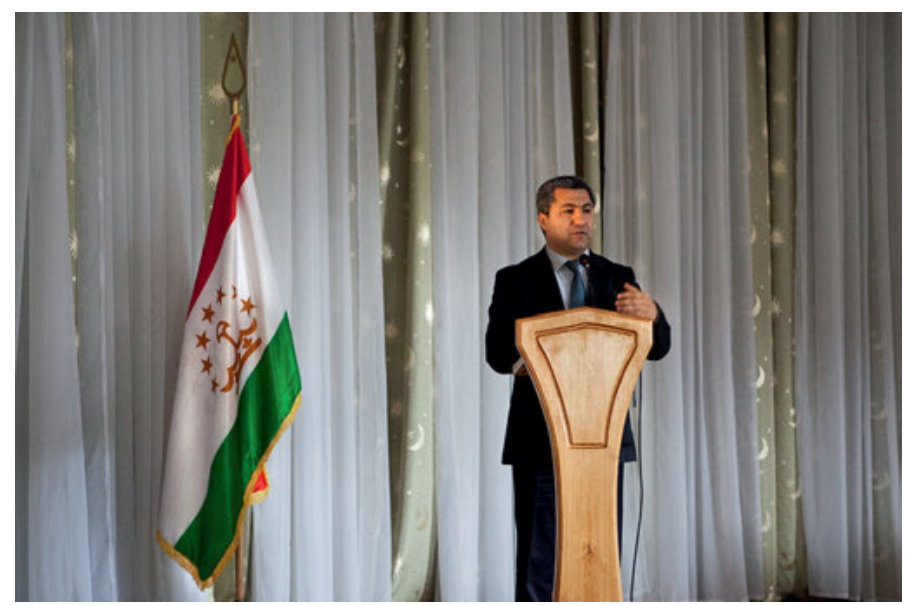

Source: Lisa Harand

The reasons for these demands are that since the peace accords the IRPT has been losing seats in parliament. After the 2010 elections it received only two parliamentary seats (which means a share of less than $3 \%$ instead of the assured 30\%) and no ministerial posts. The party therefore accuses the government of election fraud.

The Tajik government fears the IRPT and closely monitors its operations. The party, for example, has to provide the names of all members to the government. As it fears the repression of its members the IRPT does not 
release all names or sometimes advises sympathizers not to become members (they fear, for example, that officials or Muftis could lose their job if they were known to be party members) (interview with Kabiri). Also in other regards the party does not fully respect the law: it is, for example, a fact that the party holds illegal prayers at its headquarters in Dushanbe, which is forbidden by a law that restricts Muslim worship to mosques, homes, and cemeteries.

According to a researcher for Alert International, the party is totally powerless at the moment. It usually only criticizes governmental policies on religious issues and tries not to jeopardize the relatively good relationship it currently has with the government by avoiding any open confrontation. Confronted with the party's powerlessness, Kabiri explains that the party is far too interested in stability to engage in protests such as demonstrations (interview with Kabiri).

\subsection{MOdERnists AND NeO-Fundamentalists: SOCIAL TRANSFORMATION}

As has already been stated, Central Asian governments tend to classify all Salafi influences on Islam in their countries as foreign. This is why it is especially important to have a closer look at actually foreign movements even more so because it is undeniable that transnational movements have a stark influence on Central Asians and on how Islam is practiced today in Central Asia. In the following section two transnational Islamic groups will be presented which declare themselves as apolitical and non-violent: the Turkish Gülen movement and the Pakistani-Indian Tablighi Jama'at. Both are presented as examples of religious movements aiming at the transformation of the society. Whereas I describe the Gülen movement as modernist, the Tablighi Jama' at are fundamentalist and backward-looking. For this reason the current chapter begins with Figure 9 which shows different understandings of the relationship between religion and modernity. For the PEW survey Central Asian Muslims were asked:

- whether they think there is a conflict between religion and modern society; and

- whether they think there is a conflict between religion and science. 
Figure 9: Relationship between Religion and Modernity

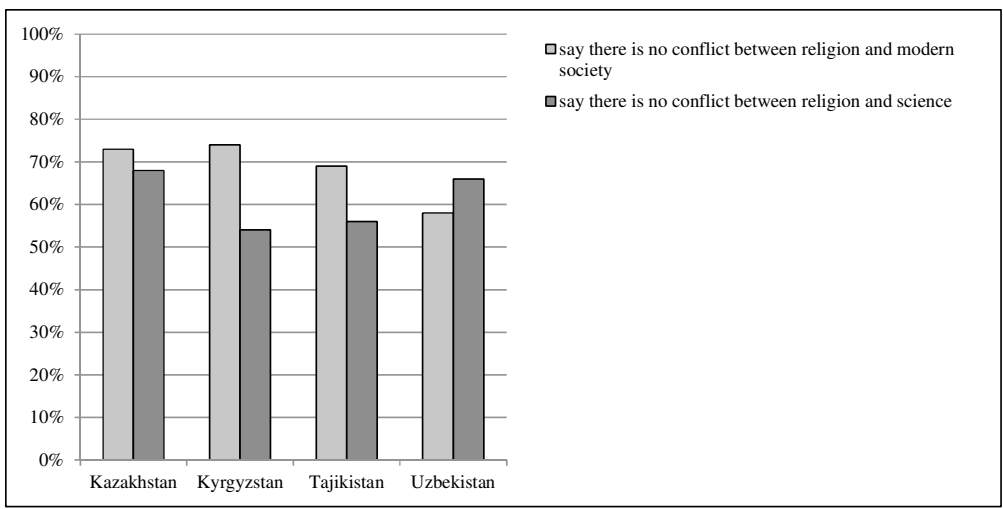

Source: PEW 2013

As we can see from Figure 9, the majority of Central Asian Muslims are neither backward-looking nor anti-modernist. On the contrary, most Central Asians are among those who are "least likely to see a conflict between being devout and living in the contemprorary world" compared to other regions in the world (PEW 2013: 128). This may help account for the extraordinary expansion of the Gülen movement in the region over the last few years.

\subsubsection{Nurcu and Gülen Movement}

The Gülen movement is named after Fetullah Gülen, a Turk who currently lives in the United States. The Gülen movement (FG), which also calls itself Hizmet movement is a neo-Nurcu movement, ${ }^{5}$ an offshoot of the original Nurculuk movement, which was founded by Bediüzzaman Said Nursi (1876-1960). Nursi "was educated in a Naqshbandi circle", but although he placed an emphasis on mystical and spiritual Islam, he was never a member

5 See for example Gülen News: http://gulennews.de/. 
of a Sufi order (Kuspinar 262; Mardin 2009: 257f). ${ }^{6}$ He believed that Muslims should take advantage of western technology and knowledge and was interested in developing a new form of education, combining religious and positivist sciences (Kuspinar 2009 260; Mardin 2009: 258). His goal was to establish a republic based on Islamic principles and Turkish nationalism (Markedonov 2013: 25). The Gülen movement, however, is not political; Peuch describes it as a socio-religious movement (Peuch 2004). It places a particular emphasis on education at the secondary school level ( $9^{\text {th }}$ to $11^{\text {th }}$ grade). Additionally, the movement finances universities such as Suleyman Demirel and Ahmet Yesevi University in the Kazakh cities Almaty and Turkistan, as well as the Kyrgyz-Turkish Manas University in Bishkek (Peuch 2004).

\section{Image 6: Manas University in Bishkek}

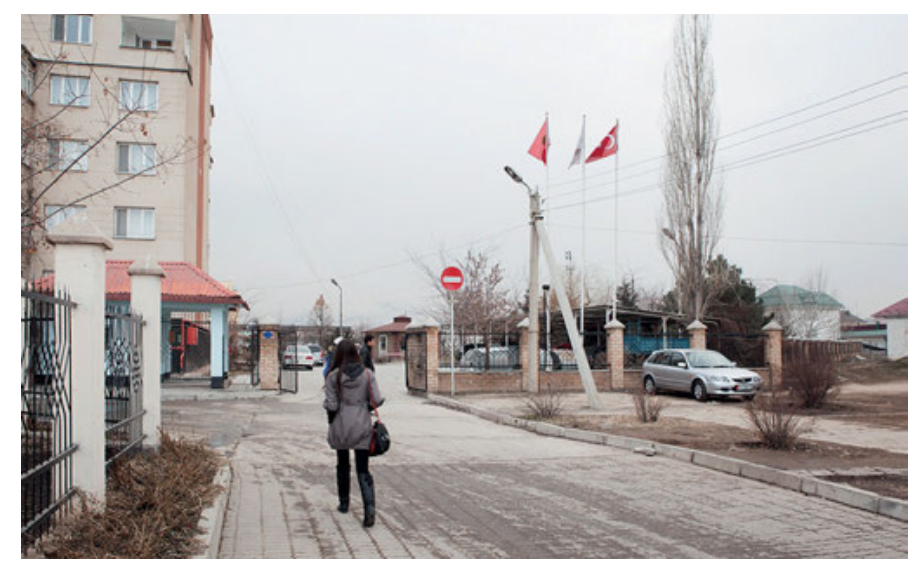

Source: Lisa Harand

Fetullah Gülen, who was born in Erzurum in 1942, "has had a complicated and controversial relationship with Turkish authorities" (Markedonov 2013: 25). He was accused of clandestine religious activities, indoctrinating

6 Despite this, the World Almanac of Islamism describes the Gülen movement as 'mainstream Sufism'. See: http://almanac.afpc.org/fetullah-g\%C3\%BClen-move ment. 
youths in illegally run summer camps, and infiltrating the Turkish military (Markedonov 2013: 25). Yet although Gülen was accused of diverse offenses against the Turkish state, today his activities are considered as "useful for the promotion of Turkish national interests. The movement therefore benefits from the support of the Turkish embassies" abroad (Markedonov 2013: 26). According to Peuch, "it is in Kazakhstan, where it has some 27 schools, that the Gulen community has been the most successful [...]" (Peuch 2004) but the movement is active in all Central Asian countries. The common ethnic origins that Kazakhs, Kyrgyzs and Uzbeks share with Turks not only explains the special influence the movement has in Central Asia; the fear that it is spreading a pan-Turkish ideology is at the same time the main reason for governmental restrictions on its schools, especially in Uzbekistan and in Persian Tajikistan. However, the lack of educational resources in Central Asian countries has led many to welcome the Turkish schools, especially in Kazakhstan and Kyrgyzstan:

"[...], unattractive salaries have drained the profession of many of its most competent teachers and university professors. With its teams of dedicated Turkish-born teachers and its emphasis on modern technology, the Gulen community has helped local governments overcome this situation" (Peuch 2004).

In addition to the high educational standard, many parents send their children to Gülen schools because the fees are economical (Markedonov 2013: 27; interviews with sympathizers of the Gülen movement). In Bishkek I was able to observe first-hand how well-equipped the private 'Silk Road International School' is. It is headed by a Turkish director while teachers come from different Islamic countries. Sports and performance spaces are available and pupils already begin receiving English instruction at kindergarten level. The students' parents work for the Kyrgyz government or for international organizations. It is not uncommon to see nine-year old school children playing with their iPhones during recess or paying with $\$ 100$ bills at the school's kiosk.

In the literature, the running of private schools is more prominently treated than the maintenance of charity lyceums. It is even often stated (e.g. Peuch 2004) that the education provided by the movement is totally secular. However, my research revealed different findings: in Dushanbe I was informed that students at these schools who receive a special promotion be- 
cause of their high school achievements have almost no free time because of their very tight timetables which not only include lessons and time for homework but also Islamic learning and reading namaz. In this way a 17year old boy is busy from 5am in the morning until 10pm in the evening with one hour off at midday (interview with an independent Tajik researcher). What has to be stressed, though, is that although the secondary schools claim not to be especially religious, there are stories of parents of students who have expressed concerns regarding either the religious transformation of their children or a very tough timetable without any free time (see also Markedonov 2013: 27). In addition, I can give an example of an Islamic college in Bishkek, a madrasa, which is also sponsored by the Gülen movement. Forty students from all over Kyrgyzstan receive three years of free secondary education there. ${ }^{7}$

\section{Image 7: Madrasa supported by Gülen Movement in Bishkek}

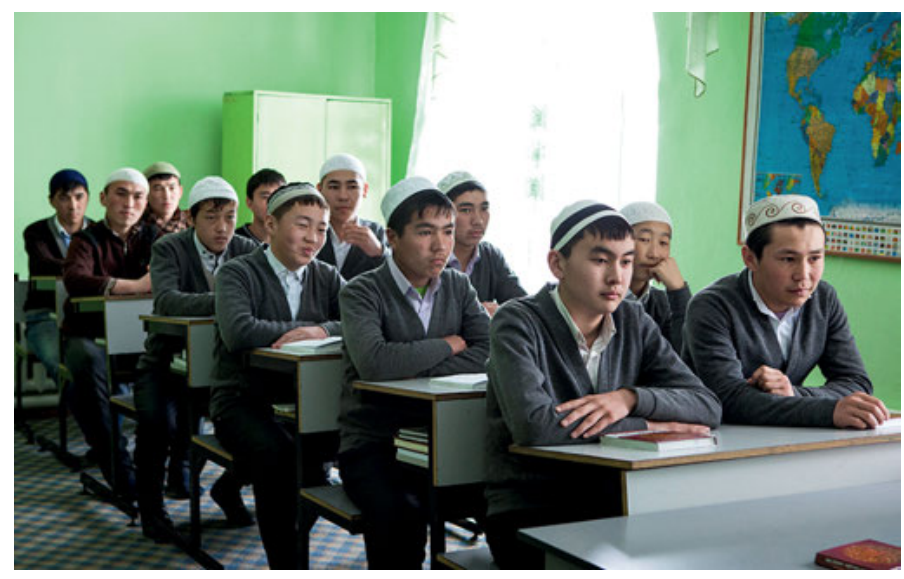

Source: Lisa Harand

The students have to pass an entrance examination but afterwards they are fully provided for. During the first year they live at the madrasa, and during the second and third years they live in a dormitory in the city. The founda-

7 This seems to be no exception - I was told that other such schools exist in Nary and Osh, for example. 
tion not only pays for their education but also their food (they eat together with their colleagues at the madrasa), accommodation and sports and cultural activities (interview with a sympathizer of the Gülen movement). The students are schooled in literature, history and languages but also pray together five times a day (namaz) and are instructed in Islamic subjects such as Arabic grammar, hadith and the reading of the Quran.

Generally, at Gülen schools special emphasis is laid on sciences, ethics, and self-discipline. (Peuch 2004). The teaching is usually in English and Turkish but also in local languages (Peuch 2004). When I met members of the movement in Kyrgyzstan I was astonished by their excellent language skills and how well-travelled they were. To give an example: one of my Kyrgyz interview partners had lived abroad for seven years, mainly in Turkey and Switzerland, obtaining a Masters degree in Business Administration in the latter. Today he works in a business consultancy for foreign companies in Kyrgyzstan. His office is affiliated to the Gülen movement and located in a building together with other Gülen enterprises. One of these is a charitable organization and another is 'Radio Maral' - the Gülenradio for Kyrgyzstan.

Image 8: Gülen Radio Maral in Bishkek

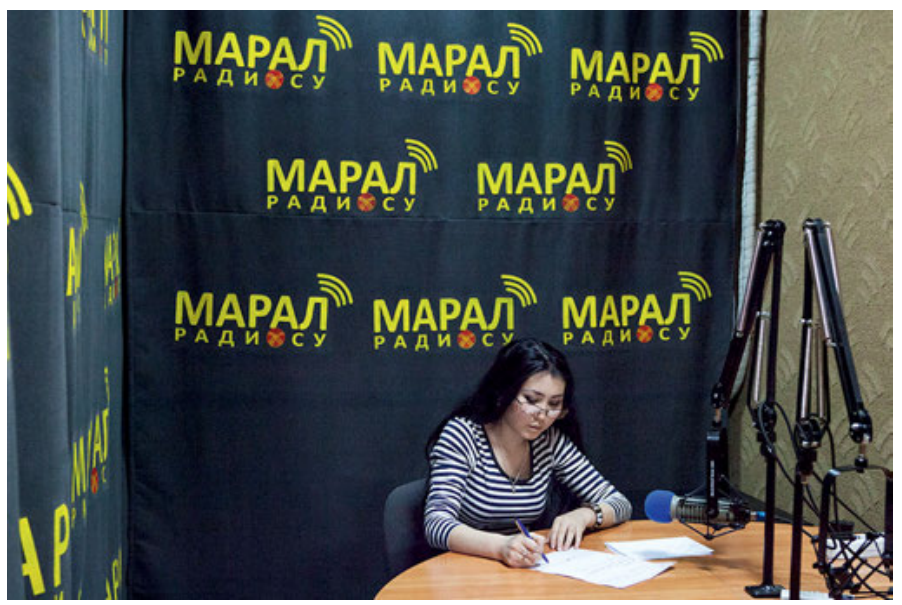

Source: Lisa Harand 
It is very typical for the Gülen movement that apart from education, it is active in the fields of business, media and charitable work. Indeed, the movement not only runs schools but also large and small businesses, student apartments and even organizes weekly 'discussion circles'. This explains why schools are being built by either Gülen-owned or Gülen-linked companies such as the Turkish company Serhat or by organizations such as the Tolerance Foundation (Markedonov 2013: 26f). The fact that sympathizers not only meet other members once a week to read and discuss Nursis and Gülen's texts, but also work in firms affiliated to the movement, or often live in student-homes run by Gülen (or, like my interview-partner, in an apartment rented very cheaply from a fellow sympathizer) lends this religious group the appearance of a sect. ${ }^{8}$

Apart from the fact that being a member seems to have a far-reaching effect on their lives (as it impacts which friends they have, the restaurants they choose and the places where they work and live), the following can be said of the political ideology that the movement is built on:

"In contrast to the Salafis, the Fethullahcilar movement suggests a focus on understanding Islam through education. [...] Gülen considers the primary tasks of the Fethullahcilar not to be in conflict with official policy [...] the movement interprets armed jihad as a mistake [...]" (Markedonov 2013: 26).

In the words of Fetullah Gülen, terrorism is incompatible with Islam because "in true Islam there is no terror since the killing of a human being is equivalent to disbelief (kufr)" (Gülen 2012). Besides arguing against terrorism, the Gülen movement is apolitical and it stresses the importance of tolerance and love in its interpretation of Islam (Akdag 2012). Nonetheless, government responses to the Gülen movement in Central Asia differ greatly from country to country. In Kyrgyzstan many government officials even send their children to Gülen schools, such as the International Silk Road

8 The fact that not all employees of affiliated firms are members or sympathizers of the movement could counterpose this statement (I was told that at Radio Moral, for example, only $80 \%$ of staff were sympathizers). However, this could be judged as a good recruiting-strategy since it demonstrates that not only is it interested in isolating its members from too many outside influences but also in gaining new members. 
School in Bishkek, and over time, Gülen teachings may have had a major influence on the elite for this very reason (interview with a sympathizer of the Gülen movement). In general it is clear that the influence of the Fetullah Gülen movement in Central Asia is profound and, by disseminating its modernist understanding of religion, has had a part to play in the revival of Islam in the region.

\subsubsection{Tablighi Jama'at}

Tablighi Jama'at (TJ) is a transnational movement with a global outreach and a clear centre in South Asia - in Pakistan, India and Bangladesh. The movement was founded in 1926 under the leadership of Maulana Muhammad Ilyas (1885-1944) "in the context of British colonial and cultural domination" (Reetz and Mumtaz 2009: 293) and "in order to purify Islam of Hindu and Christian influences" (Roy 2004: 156). The group follows "orthodox Deoband traditions and emphasize taqlid (following the established schools of Islamic law) over ijtihad (independent reasoning)" (Reetz and Mumtaz 2009: 297). It has 12 to 15 million followers worldwide and spread to Central Asia in the 1980s (Reetz and Mumtaz 2009: 293, 295). Today, Tablighi Jama' at is considered "the largest Muslim missionary group in the world [...], its annual conference has become the second largest Muslim congregation after the hajj" (Ismailbekova \& Nasritdinov 2012: 180).

The members of this Islamic missionary movement do not proselytize among non-Muslims. Instead they seek to bring Muslims back to "true Islam" and correct their practices (Markedonov 2013: 29). Tablighi Jama' at attaches considerable importance to dawat - preaching by inviting others to the mosque. Every Tabligh should fulfil this duty in exact time spans: three days per month, one month per year and four months in a lifetime (see Nasritdinov 2012). This means that preaching is not restricted to the clergy but that "everyone who joined the Jama'at became an instant preacher" (Reetz and Mumtaz 2009: 295). The dawat is strongly connected to travelling. Nasritdinov very neatly explains the implication travelling has for the spiritual experience and process of a Tabligh (Nasritdinov 2012). On their journeys the members of the movement are organized in groups (jama'at) of 10 people who "invite the local Muslims to assemble in the mosque or some other meeting place, and present their message in the form of six directives" (Reetz and Mumtaz 2009: 294). 
Roy regards the fact that every Tabligh is an instant preacher as grounds for classifying the movement as neofundamentalist. He argues that neofundamentalists are more interested in the immediate experience of faith than in thorough religious knowledge and scholarly learning (Roy 2004: 165). Along with Salafis and other fundamentalists, the movement shares a strong disdain for Sufi practices and other 'innovations', as Reetz and Mumtaz explain:

"It rejects such popular expressions of religion as the veneration of saints, visiting shrines, and observing the syncretic rituals associated with popular Sufism. Jama' at workers are rigid in following orthodox rituals and practices and in observing the rules of shari'ah" (Reetz and Mumtaz 2009: 297).

The fact that the movement is rather more interested in the transformation of the individual and less in social change also fits Roy's classification of Tablighi Jama'at as a neofundamentalist movement. Karagianni also states that the group can be considered neofundamentalist because it operates mosques and schools (Karagiannis 2010: 52).

Despite this, my own experience with a member of Tablighi Jama'at was that of a quite tolerant person. Although he explained on a theoretical level why he did not regard it as correct to pray at a saints' grave, he did read the Quran for the other people present at this place because he was the most knowledgeable person there. Such tolerant behaviour does not fit Roy's neofundamentalist description. Furthermore, Nasritdinov's research and his work with Ismailbekova, in which they reveal conflicting observations, make me hesitant to conclude that we are dealing with an exclusionary organization or movement.

In terms of its political ambitions it seems appropriate to conclude that since the movement is primarily interested in the transformation of the individual into a good Muslim, it is apolitical. As Alexiev makes clear:

"Tablighi Jamaat officials work to remain outside of both media and governmental notice. [...] By eschewing open discussion in politics and portraying itself only as a pietistic movement, Tablighi Jamaat works to project a nonthreatening image" (Alex Alexiev, cited in Markedonov 2013: 28). 
Reetz and Mumtaz (2009: 292) also consider Tablighi Jama'at to be apolitical citing as reasons the fact that it neither aspires to an Islamic state such as a caliphate nor proclaims armed jihad. In certain countries, such as Pakistan, India, Indonesia and Malaysia, the movement even profits from the fact that governments accept it as an "antidote to militant Islam" (Reetz and Mumtaz 2009: 298). Not so in Central Asia: Uzbekistan banned Tablighi Jama' at as an extremist organization in 2004, Tajikistan followed in 2006, Russia in 2009 (Markedonov 2013: 29) and Kazakhstan in 2013. Only in Kyrgyzstan is the movement still able to operate legally, though its missionary trips are regulated by the Muftiate.

It is difficult to give a clear answer regarding the movement's organizational structure. Whereas Tablighis themselves claim not to have a strong formal organization, "a closer look at their functioning reveals that this is far from true. Their international administration has become very strong and robust" (Reetz 2008, cited in Ismailbekova \& Nasritdinov 2012: 183). Indeed, its vertical and horizontal structures appear to function fairly well as we see in the example of Kyrgyzstan. Here a national council called mashura (Arabic for council) oversees the adherents of the movement (Zenn 2013). Decisions concerning domestic issues are taken at these national councils and, "are passed down to the regional, city and local levels" where they reach the individual mosques (Ismailbekova \& Nasritdinov 2012: 183). Moreover, Ismailbekova and Nasritdinov write that on their trips to India, Kyrgyz jama'ats:

"[...] report the success and difficulties of their practice in Kyrgyzstan: the range of issues reported can include the number of 3-day, 40-day and 4-month jama'ats, which travelled inside Kyrgyzstan and abroad, the quality of everyday local efforts, the main patterns and trends in comparison to previous years, etc. They also receive instructions and recommendations form the veterans of the movement, which are then brought back to Kyrgyzstan" (Ismailbekova \& Nasritdinov 2012: 183).

Despite this, the impact of the existence or non-existence of a hierarchical structure with regards to fundamentalist elements in the movement remains open to discussion. Ismailbekova and Nasritdinov and a researcher for Alert International all argue that only a strong leadership and hierarchical structure could prevent the Tablighis from being overrun by political movements (Ismailbekova \& Nasritdinov 2012: 183; interview with researcher for Alert 
International). Nevertheless, my interview partner from Alert International questions Ismailbekova's and Nasritdinov's assertion that the organization is strong enough to resist fundamentalist elements. Furthermore, there are critics who argue that the movement is Salafi; that it aims at establishing a global Islamic caliphate, and even maintains connections to al Qaida (Zenn 2013). However, these arguments refer to individual relationships or changes of members of one group to the other rather than organizational links between the two groups (interview with a researcher for Alert International).

\section{Image 9: Kyrgyz Member of Tablighi Jama'at}

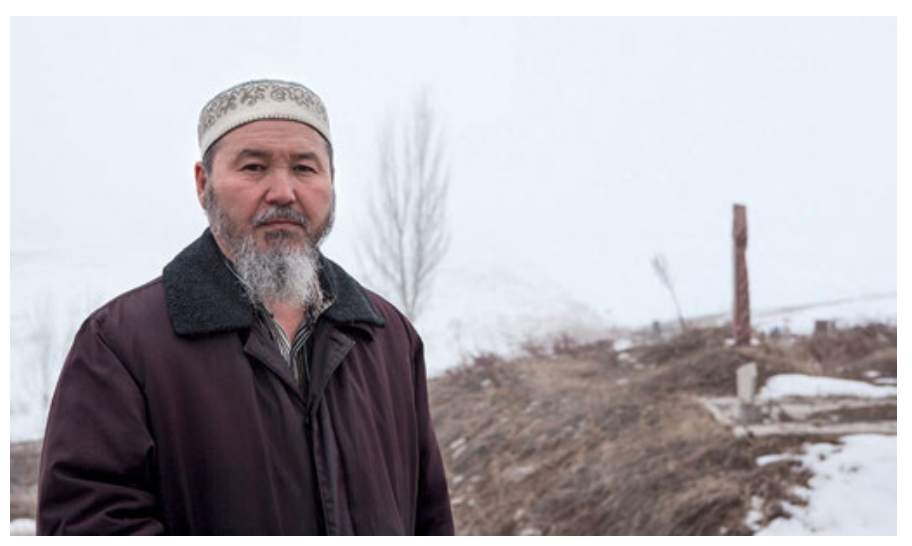

Source: Lisa Harand

Compared to the progressive Gülen movement Tablighi Jama'at is backward-looking and conservative. At first sight Tablighis seem to be much more devout than Gülencis because of their Pakistani dress code of long shirts and wide trousers. My Tabligh interview-partner, for example, described himself as God's slave, which sounds extreme. By contrast, a sympathizer of the Gülen movement with his band collar shirt, v-neck pullover and intellectual speech seemed moderate and almost western. Which of these two movements is having a broader effect on Islam in Central Asia? This question is impossible to answer in the scope of this study. However, it seems to me that the Gülen movement is much more difficult to pin down than the Tablighi Jama'at. Moreover, the Gülen movement's projects 
to transform society are much more diversified and complex than the Tablighi's proselytising efforts among fellow Muslims. 


\section{Typology of Islamic Groups}

\subsection{Folk-IsLamic Groups}

The revival of Islam has manifested itself in the resurgence of Islamic rites in the personal lives of Central Asians and in the increase of visitations to the graves of saints (Kehl-Bodrogi 2006: 236). In the wake of 9/11, this revival of Islam can easily be misinterpreted as a strengthening of fundamentalist Islam. A more objective perspective and a more thorough analysis revealed, however, that many different groups have contributed to this revival. To fully understand this phenomenon, these groups need to be differentiated from each other and studied separately. As was demonstrated in the last chapter, 'extremist' and 'foreign' Islamic groups have gained ground in Central Asia. More importantly, though, is the larger impact which has been made by the increased popularity of the following traditional religious practices:

- Sufism

- mazar-worshipping

Research has shown that Sufism is most widespread in Tajikistan and Uzbekistan and to a lesser degree in Kyrgyzstan. In Kazakhstan, however, Sufism is not very popular. It is important to understand that religious folk practices such as the invocation of ancestors and the visitation of holy shrines are traditional practices in Central Asian Islam and are therefore accepted by the majority of citizens in all Central Asian countries. Indeed, these practices are accepted as a part of their Islamic beliefs.

Sufism is always bound to a very hierarchical organizational structure and can become political under certain circumstances. Although there are 
many similarities to mazar-worshipping, the latter is less organized and I do not know of any political mobilization of mazar-shayks for example. I assume that the increased influence of folk Islamic groups after the independence of the Central Asian countries was not due to the proselytizing efforts of their members. Instead, the perceived stronger influence can better be explained by the change in the behaviour of the general population which previously had had to hide its religiosity but was now permitted to express it more openly. Thus a large part of the revival of Islam in Central Asia can be attributed to the reemergence of folk Islam in the public sphere which was a result of a greater freedom to express religious beliefs.

\subsection{Non-Traditional ISLAMic Groups}

Apart from a reinvigorated folk Islam, proselytizing efforts of Salafi groups further contributed to the revival of Islam in Central Asia. Salafis intend to re-establish a Muslim society as it existed during the life of the Prophet Muhammad and the first three generations of Muslims. While all Salafis undertake proselytizing efforts to achieve this goal the movement is nonetheless very diverse, as I have shown in the previous chapters. In spite of the similarities described in 3.2.1, Salafis can be differentiated according to their relationship to politics and to the means they adopt for their political struggle. There are modernist Salafis who seek to Islamize society through education and embrace modernity; fundamentalist Salafis who are backward-looking and reject any political engagemen, and there are also political Salafis who I call Islamists because they use Islam as a political ideology. Important to note is that not all Salafis are jihadis, who receive the most attention in the (western) media due to their call to violent action (Haykel 2009: 26). Also, when we refer to the concept of jihad, we must bear in mind that no other Islamic expression has ever been as misused as often as this one. Jihad, which is usually translated as holy war, though a closer meaning would be effort, is not restricted purely to external conflict and aggression but also denotes the internal and defensive struggle of Muslims (Halbach 1989: 216). As was shown in section 3.1.1 the understanding of jihad is an important criterion when differentiating between the different Salafi groups: 
"[...] Salafi mainstream ulama consider jihad as a collective rather than an individual duty. They also believe that even if there is jihad, there are rules of conduct during war that should be respected" (Roy 2004: 254).

Jihadis on the other hand regard jihad as an individual duty and use this concept to legitimize violence against civilians.

In order to discuss the relationship between Islam and politics in Central Asia, it will be helpful to adhere to the following definitions of the relevant groups:

- I use the term 'non-traditional' for all those groups who reject Central Asian religious folk traditions, the commingling of religious practice with pre-Islamic rituals and the interwovenness of religion and ethnicity.

- It is my understanding that Salafis are those Muslims who have a social utopian non-traditional ideology and attempt to proselytize others in order to purify Islamic society.

- Islamists refer to all Salafis who politicize Islam and who use Islam as a political ideology in order to Islamize society.

- Jihadists are those Islamists who furthermore justify the use of violence to achieve the same goal.

All these groups share the common feature that they reject the influence of culture and tradition on religion and in this sense can be regarded as nontraditional. Furthermore, they are Salafis (or neo-fundamentalist according to Roy's definition) as they wish to bring the society back to the 'true' faith of the first three Muslim generations. Whereas all groups hope to transform society in one way or another, both modernists and fundamentalists aim at transforming society from the bottom up, whereas Islamists and jihadists try to Islamize society from the top down. I suppose that all jihadists are Islamists, although there might be some difference in the importance they attribute to religion and politics. Whereas Islamists are primarily political and refer to religion as the basis of their political activity, jihadists do the opposite: they are primarily religious and, as Roy maintains, their only political act consists of declaring the religious law to be the law of the land. I assume furthermore, that Islamists can resort to violent means (and become jihadists) although remaining primarily political under certain circumstanc- 
es (such as during the Tajik civil war, where the IRPT was engaged as an armed conflict party).

I would like to summarize the definitions mentioned above as follows:

Table 2: Typology of Non-Traditional Islamic Groups

\begin{tabular}{|c|c|c|c|c|c|}
\hline & 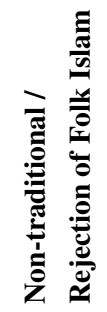 & 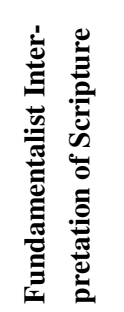 & 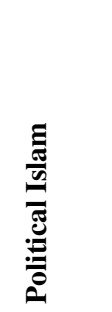 & 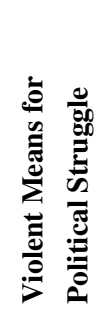 & 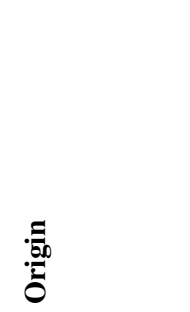 \\
\hline FG & $\checkmark$ & & & & Turkey \\
\hline $\mathrm{TJ}$ & $\checkmark$ & $\checkmark$ & & & India/ Pakistan \\
\hline IRPT & $(\checkmark)$ & $\checkmark$ & $\checkmark$ & $(\checkmark)$ & Sowjet Union \\
\hline HT & $\checkmark$ & $\checkmark$ & $\checkmark$ & & Palestine \\
\hline IMU & $\checkmark$ & $\checkmark$ & $\checkmark$ & $\checkmark$ & Uzbekistan \\
\hline $\begin{array}{l}\text { Actor- } \\
\text { Type }\end{array}$ & $\begin{array}{l}\checkmark= \\
\text { Salafi }\end{array}$ & $\begin{array}{l}\checkmark= \\
\text { Funda- } \\
\text { mentalist }\end{array}$ & $\begin{array}{l}= \\
\text { Islamist }\end{array}$ & $\begin{array}{l}= \\
\text { Jihadist }\end{array}$ & $\begin{array}{l}\text { Foreign vs } \\
\text { Central Asian }\end{array}$ \\
\hline
\end{tabular}

As we will see in the next chapters, Central Asian governments seek to lump all these groups together as negative foreign influences on homegrown Islam. Contrary to Central Asian folk Islam, which is closely intertwined with the Sunni Hanafi School and is open to pre-Islamic customs and traditions known as urf and 'adat, Salafis traditionally refer to the Hanbali school of law. Because of their desire to live a pure Islam, Salafis reject such local traditions as bid'a (unjustified innovation). However, this does not mean that all Salafi groups in Central Asia are nonHanafi. On the contrary, most adhere to the local school of law to some degree or simply reject the identification with any legal dimension of Sunni Islam. This is further proof of the heterogeneity of religion. Additionally, not all Salafi groups active in Central Asia have a foreign origin; the Islamist IRP and the jihadist IMU, the only two groups who have openly promoted violent means in their political struggle (with regards to the IRPT this 
was the case during the civil war but is no longer true), are genuinely Central Asian groups.

Even though it is true that Salafism has certain Central Asian roots as can be found in groups such as IRPT and IMU, foreign groups such as HT, Fetullah Gülen and Tablighi Jama'at have had a large impact on the new strength of the scriptural interpretation of Islam in the region. As these groups have only come to the region during the last few decades, it is wrong to describe their diffusion as simply a revival of Islam - instead we have to bear in mind that the majority of the Salafi groups have brought new interpretations of Islam to Central Asia. Although the religious policies of the Central Asian states are highly controversial (as we will see in the next chapters), they are based on these proselytizing efforts by foreign and domestic Salafi groups. 

PART II POLITICS AND ISLAM:

CASE STUDIES OF POLITICAL REGIMES 



\section{History of Politics and Islam in Central Asia}

Central Asian history is important for gaining an understanding of the contemporary religious policies of the independent states. For example, the Uzbek nation-building strategy refers to Timur while the contemporary Muftiates have their origin in the Soviet offices, which in turn are the successors of tsarist institutions. But history is also necessary to help us understand non-state movements. For example, the involvement of Naqshbandiyah tariqa in politics centuries ago, its suppression during tsarist and Soviet times, as well as the mobilization-potential it demonstrated during this period, helps shed light on its current status. This chapter does not seek to give a general overview of the history of the region, but is rather more concerned with the development of contemporary religious self-images and governmental restrictions on Islam. In order to gain an overview of the many different aspects which have played a role in Islam in the past and still have an influence today, I summarize in this chapter the history of the most important empires in the region, as well as internal developments within Islamic thinking and practice. I start with the Islamization of the region.

\subsection{EARLY EMPIRES AND ISLAMIZATION OF Central Asia}

Islam is one of the main world religions and it is the prevalent religion in Central Asia. It spread from contemporary Saudi Arabia, where Prophet 
Muhammad lived in the $7^{\text {th }}$ century, to other regions. Ever since Arab conquerors first incorporated Transoxiana, also called Mawarannahr (the lands between the Amu Darya and the Sir Darya), into the Arab caliphate in the $8^{\text {th }}$ century, different waves of Islamization have spread through Central Asia (Naumkin 2005: 6).

From the $8^{\text {th }}$ century onwards, different Muslims and Muslim groups from Central Asia have shaped the history of the Muslim world, and the region, "could present a unique success story in the Islamic world" (Kaplony 2005). For centuries Bukhara was a centre of Islamic learning: it is the birthplace of one of the most important Sufi orders, the Naqshbandiyah, and famous personalities such as the jurist Abu Mansur Muhammad alMaturidi, the scientist Abu Nasr al-Muhammad al-Farabi and the rationalist philosopher Abu 'Ali Ibn Sina all originated from this region (Khalid 2007: 25).

Generally speaking, the people living around the oases on the Silk Road were the earliest Central Asian converts to Islam because they were the first to come into contact with merchants advocating the new religion.

"One decisive factor in the Islamization of Central Asia was the bustling caravan transport. The merchants were amongst the first to spread Islamic religion and culture" (Schlageter 2003: 74, translated by the author).

As a result, the first Islamic strongholds in the region were the cities of Bukhara, Samarkand and Kokand (Schlageter 2003: 161). The sedentary people in these cities were Islamized by the Arabs of the Abbasid caliphate in the $8^{\text {th }}$ century. By contrast, the nomads in the region were less accessible for the new religion and so their conversion took a great deal longer, as Khalid explains: "Many nomads entered the orbit of Muslim civilization [...] from the tenth century on, but conversion to Islam was a gradual process that lasted into the eighteenth century" (Khalid 2007: 26). Under the Qarakhanid dynasty many nomads of the Kazakh Steppe were Islamized in the second half of the $10^{\text {th }}$ century (Schoeberlein 2009: 99) and from the $10^{\text {th }}$ to the $12^{\text {th }}$ century Tajik merchants brought Islam to the nomads who lived on modern-day Kyrgyz territory (Karagiannis 2010: 33). Yet more important for the conversion of the nomads than the spreading of Islam by commerce, however, were "the efforts of charismatic Sufi shaykhs" (Schoeberlein 2009: 103). It was under their influence that the conversion 
of Kazakh nomads continued until the eighteenth century (Schoeberlein 2009: 99, 220).

As we can see, the Islamization of the Central Asian peoples depended on their way of life on the one hand. Conversely, their way of life had an influence on how the new religion was practiced. Whereas we can find many impressive Islamic monuments in the traditionally sedentary regions (mainly in Uzbekistan but also in Tajikistan), there are few historical Islamic buildings in the lands of the nomads in mountainous Kyrgyzstan or in the far reaching steppes of Kazakhstan.

Due to such differences, as well as the fact that the nomads were Islamized later than the sedentary populations, it has often been said that the nomadic peoples are less religious than the sedentary ones (Schoeberlein 2009: 103). Thereby the assumption has been that Islam today is rooted to a lesser degree in a society if the society was originally (even hundreds of years ago) coerced to convert; if it was Islamized at a later point in time, or if it tended to abstain from the usage of written sources (all this is said to be the case with the nomadic societies in Kazakhstan and Kyrgyzstan - although the latter is not true as we could see in 3.2.1). However, "no consistent relationship can be observed anywhere in the Islamic world between high levels of literacy and devotion to Islam, and [...] right from its beginnings in the core of the Arab world, Islam has found strong adherents among nomads" (Schoeberlein 2009: 103). As a consequence, Schoeberlein proposes not to exaggerate the importance of reading the Quran as an indicator of religiosity. In any case, it is true that there still are some differences between the originally nomadic peoples and those who have been sedentary for centuries. This is important to consider if we want to come to a conclusion regarding the contemporary revival of Islam in Central Asia.

In the following sections, I focus on the different Central Asian empires and their impact on Islam; namely whether they a) brought Islam to the region b) fought against it or c) declared it as their state dogma.

\subsection{1. $8^{\text {th }}$ Century: Umayyads}

The Umayyads (661 - 750), who were Arabs from Mecca, had their centre of power in Damascus and expanded their empire to contemporary parts of Uzbekistan, Tajikistan and Kyrgyzstan. In the late $7^{\text {th }}$ century they controlled Bukhara, Samarkand and the Ferghana Valley under Umar II (Ber- 
zin 1996). It was predominantly people living in cities who adopted the new religion in the mid-eighth century. The Arabs' primary interest was not the expansion of Islam, but rather the military and economic advantages they could gain by controlling the Silk Road (Berzin 1996). A mass conversion of non-Muslims would have signified a financial loss for the new rulers because only non-Muslims would have had to pay a poll tax (Enderlein 2005: 61). At any rate, the Arabs were the first who brought Islam to Central Asia and changed the life of the occupied people to a great extent:

"In order to integrate Transoxiana into their domain, it was not unusual for the Arabs to take drastic measures. The land was declared property of God or rather property of God's surrogate on Earth. It was leased and taxed" (Schlageter 2003: 74, translated by the author).

Interestingly, the so called waqf religious property remained important until the very beginning of the communist era. ${ }^{1}$

\subsection{2. $8^{\text {th }}-13^{\text {th }}$ Century: Abbasids}

The Umayyad Empire was troubled by internal quarrels and finally destroyed by the Abbasids (749 - 1258). They were supported by Persians from the 9th century on and adopted the Persian style of administration (Blair and Bloom 2005a: 93). The Abbasids legitimized their fight against the Umayyads by labelling the older regime 'unholy' and by tracing their right to rule back to the uncle of the Prophet Muhammad (a relationship that was closer to the Prophet than the Umayyads') (Enderlein 2005: 63; Blair and Bloom 2005a: 91). It is important to note that when Kalif alMamun was in power, questions such as human freewill were broadly discussed in Islam. ${ }^{2}$ He promoted the rationalistic view on this matter (which

1 For the contemporary role of waqf in the Islamic world see: http://webcache. googleusercontent.com/search?q=cache:TpBQClBR0hEJ:www.unhabitat.org/ downloads/docs/3546_80031_ILP\%25207.doc+\&cd=5\&hl=de\&ct=clnk\&gl=ch.

2 "The dispute between the traditionalists and the rationalists took on very harsh forms, sometimes even within the same madhhab. Whereas the former made an absolute out of emulating authority (whether books or preceptors), the latter largely relied on methods of reasoning, analogies, and mental conclusions (eve- 
was opposed predominantly by Ahmad ibn Hanbal, the founder of the Hanbali School of Law), declared it as state dogma and pledged the ulama to avow themselves to this interpretation (Blair and Bloom 2005a: 90). The following quote summarizes the Abbasids' theology:

"First, they stressed the absolute unity or oneness (tawhīd) of God. From this it was logically concluded that the Qur'ān could not be technically considered the word of God (the orthodox view), as God has no separable parts, and so had to be created and was not coeternal with God" (Encylopaedia Britannica c).

This rationalistic religious view was coupled with great military power. With their capital in Baghdad and Samarra, the Abbasids derived their military force from guards from Central Asia, who they could rely on when internal quarrels threatened their power (Blair and Bloom 2005a: 93). The loyal army of the caliphate became known as Mamluks, who were mainly slaves with Turkic roots (Encylopaedia Britannica c).

\subsection{3. $9^{\text {th }}-10^{\text {th }}$ Century: Samanids}

During the rule of the Abbasids, many parts of their empire were controlled by different local dynasties as well as by independent empires which were under the suzerainty of the Abbasids. In this way, Transoxiana was ruled by the Samanids 875 - 999, who established their centre of power in Bukhara (Blair and Bloom 2005a: 93). Islam was their state religion (Naumkin 2005: 6) and they developed a double-identity as campaigners against pagans and Shiites, as well as protectors of Iran against the Turks (Kaplony 2005). Already during their rule, Central Asia became a hub of Muslim sciences and commerce:

rything that became the pivot of kalam). In various regions of the Abbasid caliphate, the Hanafites seriously conflicted with the Hanbalites, followers of Ahmad b. Muhammad b. Hanbal (780-855), who fully depended on the traditional sources of Islam and literal understanding of texts, admitting $r a^{\prime} y$ only as a last resort, when traditional sources could not give an answer to the question that arose" (Naumkin 2005: 9). 
"Under the loosely centralized feudal government of the Sāmānids, Transoxania and Khorāsān prospered, with a notable expansion of industry and commerce, attested by the use of Sāmānid silver coins as currency throughout northern Asia. The main cities of Samarkand and Bukhara became cultural centres. Persian literature flourished in the works of the poets Rūdakī and Ferdowsī, philosophy and history were encouraged, and the foundations of Iranian Islamic culture were laid" (Encylopaedia Britannica d).

Although these philosophers were Persians, the contemporary Turkic Central Asian states refer to them - for example one of the biggest universities in Almaty, Kazakhstan, is named after Ferdowsi. From the Samanid dynasty on, the present-day Uzbek cities remained

"[...] important centers of Islamic learning and culture, as market centers on the Silk Road, and as the core of major world and regional powers from the Samanids to the Chagatayids, Timurids and Shaibanids [...]" (Schoeberlein 2009: 99).

As we will see later on, reference to the historical importance of these cities is an important part of contemporary nation-building by the Uzbek government.

\subsection{4. $10^{\text {th }}-12^{\text {th }}$ Century: Qarakhanids and Seljuks}

The Samanid dynasty disintegrated in 999, and the Turk Qarakhanids took over in Transoxiana, but they soon came under the control of the Seljuqs (Encylopaedia Britannica a).

The Seljuqs (Great Seljuq Empire: 1038 - 1157) were Turkic nomads from the Oghuzen confederation of tribes, who were deployed by Central Asian rulers to fight the Arab invaders. Around 960 AD they converted to Islam and secured their own territories. For some time, they controlled one of the most far-reaching Muslim regimes (Hattstein 2005a: 348). Because of their Turkic origin they could not claim a direct relationship to the Prophet Mohammad. Instead, they relied on honorary titles which they received from the caliph in Baghdad to religiously legitimize their rule (Hattstein 2005a: 348). Under the rule of Nizam, the Seljuks promoted the integration of Sufism into the state religion, maintained many excellent madrasas, and established a strong central power (Hattstein 2005a: 350ff). 
In addition to honorary titles they also sought to legitimize their rule through an increasing reliance on sharia as a system of positive jurisprudence; through the maintenance of political stability, as well as through their prosperity (Hattstein 2005a: 352).

The relationship between Seljuks and Qarakhanids shifted. Whereas the Seljuqs initially came under the suzerainty of the Qarakhanids, they dominated the latter at the end of the $12^{\text {th }}$ century (Hattstein 2005a: 348; 352). Finally, the Seljuks were defeated by the Chinese Qara-Khitai in 1141 (Hattstein 2005a: 351); the Qarakhanids fell under the domination of the latter, and the regime of the Seljuks disintegrated in 1157 AD (Encylopaedia Britannica a). At the very beginning of the $13^{\text {th }}$ century the Qarakhanids gained their independence again for some years but were finally stamped out by the Shah of Khorezm (Encylopaedia Britannica a).

\subsection{5. $11^{\text {th }}-13^{\text {th }}$ Century: Khorezm-Shahs}

The Khorezm-Shahs (1077-1231) first ruled as vassals of the Seljuks in modern day Central Asia and Iran and (taking advantage of a civil war among the Seljuks) subsequently gained their independence (Encylopaedia Britannica e; Hattstein 2005a: 353). Under their rule, the Central Asian oases flourished, as Hattstein observes:

“Under the rule of Tekish's son Ala ad-Din Muahhad (1200 - 1220) the Empire of Khorezm experienced its greatest triumphs and its most precipitous fall. After 1206 he acquired the entire domain of the Ghurids (1208 he carried Herat), cast off the formal suzerainty of the Qara-Khitai in 1210 and in the aftermath enlarged his regime at the expense of the Qarakhanids and Qara-Khitai. Thereby his domain covered for a short time the largest area in the history of Islamic empires" (Hattstein 2005a: 353, translated by the author).

In spite of this high-time, the empire's decline was invoked after initially good contacts with the Mongols turned sour. In the early $13^{\text {th }}$ century, the Khorezm-Shahs maintained contact with Genghis Khan (1167-1227), the leader of the Mongols. When they imprisoned and slaughtered Mongol merchants and ignored Mongol requests for compensation, this provoked Mongol expansion to the west (Hattstein 2005a: 353). 


\subsection{6. $13^{\text {th }}-14^{\text {th }}$ Century: Mongols}

Under the Mongols, Central Asia witnessed very hard times. "Under Genghis Khan's leadership, Mongol forces destroyed numerous cities in Transoxania and Khorasan in an unprecedented display of terror and annihilation" (Encylopaedia Britannica b). This was not only a disaster for the people, but also for Islam (Naumkin 2005: 10):

"Although the Mongols did not bear any particular antimus against Islam, their actions had a destructive impact on the religious and cultural traditions of Transoxiana. Islam was displaced from its position as the recipient of political protection or patronage, and its moral and ethical imperatives were subordinated to Mongol practices" (Khalid 2007: 26).

The Mongol invasion thus brought an end to centuries of Islamic rule. Ghengis Khan replaced the Islamic sharia with the Mongol yasa, a code of law and ethics that probably goes back to the early $13^{\text {th }}$ century (Hattstein and Delius 2005: 613; Khalid 2007: 26). Whereas earlier empires had relied on their link to the Prophet Muhammad, during the next centuries the legitimacy of rule was strengthened if rulers could trace back their ancestry to Genghis Khan (Blair and Bloom 2005b: 388). "Mongol rule thus undid the hegemony of Islam in the political realm" (Khalid 2007: 27).

The situation improved for Islam when the Mongols converted in the $14^{\text {th }}$ century and re-established it as the official religion in Central Asia: Özbek Khan (1313-1341), the Golden Horde's leader, made Islam the religion of state (Schoeberlein 2009: 99; Naumkin 2005: 10). Afterwards, the Mongol Chagatayids and the Il-Khans also converted to Islam (Blair and Bloom 2005b: 388). However, the weakness of these three states allowed Timur to come to power in the $14^{\text {th }}$ century (Cannon 2009: 380 ).

\subsection{7. $14^{\text {th }}-15^{\text {th }}$ Century: Timurids}

Timur (1336-1405) was a Mongol from the Barlas tribe which used the Turkic language and therefore is sometimes wrongly considered to be a Turkic tribe: the contemporary Uzbek government, for example, publicize Timur as part of their heritage. He served as a vizier for Ghengis Khan's son Chagatai (ruler over the Chagatayids), who became Timur's first victim 
(Cannon 2009: 380). Timur took over Samarkand as capital, and the territory under his influence soon became almost as large as the former empire of Ghengis Khan. However, his dynasty could not tightly control it: "A mere hundred years after Timur's first military victories, Timurid power had fragmented into petty states" (Cannon 2009: 380). Timur's fall was therefore almost as precipitous as his rise. This was partly because he concentrated on single cities and regions and did not develop a concept for the administration of the state (Hattstein 2005b: 414).

As far as religion was concerned, he was theoretically as tolerant as his Mongol predecessors, and the formalism of the Muslim schools of law did not dominate. Instead he tried to combine the Mongol yasa with the sharia (Hattstein 2005b: 408). Under his rule, Sufism and local saints cultures flourished (Hattstein 2005b: 408). Sufism became not only an important aspect but even a dominant part of cultural life (Khalid 2007: 10):

"[...] in that era, it was no longer the ulama, as it was before the conquest, but Sufi shaykhs and ishans who played a paramount role in the religious class. Sufi symbols and rituals $[\ldots]$ became the quintessence of popular Islam, joining together diverse ethnic groups of the population" (Naumkin 2005: 10).

This led the root for the contemporary integration of Sufism into folk Islam. In spite of Timur's religious tolerance, even Muslims were among those to fall victim to his extreme cruelty. For example, during the capture of Delhi (1398): “[...] his armies wantonly destroyed the lives and property of many Muslims and Hindus" (Cannon 2009: 380). In fact, Timur was even crueller than the legendary Ghenghis Khan and the mass murder of civilians and the destruction of cultural centres could not be compensated by the cultural extension of Samarkand by deported artists and craftsmen (Hattstein 2005b: 408).

One significant change during the Timurid era was the relocation of the capital, so whereas in the past the Islamic centre had been in Persia it now shifted to Samarkand (Hattstein 2005b: 414). As a consequence, under Timur's rule, the region again became a centre of Islam and especially under Timur's grandson Ulugh Beg (1394-1449), "masterpieces of Muslim architecture - mosques, mausoleums and madrasas, such as the Shah-i Zinda ensemble, the Bibi Khanum mosque, the Gur-e Amir Mausoleum, and the Ulugh Beg madrassa, were built" (Naumkin 2005: 11). 


\subsection{8. $16^{\text {th }}-18^{\text {th }}$ Century: Shaybanids}

The Shaybanids were the successors of the Timurids in Central Asia. Their Uzbek empire was named after Muahammad Shaybani Khan (1500 1510), the chief of a confederation of Islamized Turko-mongol nomads from the steppes, who established his sovereignty over a part of Ma Wara'al-Nahr (Holzwarth 2005: 431f; Naumkin 2005: 10). In 1507 Shaybani Khan ruled over eastern Khorasan, Transoxania, Khawarszm, Turkistan and the Ferghana Valley (Holzwarth 2005: 432).

The second generation of the Shaybanid Khans in particular maintained a close relationship with the Naqshbandi Sufi order, which was able to transfer its influence from the Timurid era to the Uzbek empire (Holzwarth 2005: 432). The heads of the Sufi orders were descendents of wealthy khodja-families from diverse cities (Holzwarth 2005: 432). Amongst other things, the societal influence of the Sufi orders was one reason why the region did not expand beyond externally demarcated borders (Holzwarth 432). Bukhara was the main capital of the Shaybanids in the $16^{\text {th }}$ century because it had been of great importance for Islam since ancient times and was also the stronghold of the Naqshbandiyah (Holzwarth 2005: 433). During this empire, Bukhara replaced Samarkand as the economic centre and Silk Road junction (Holzwarth 2005: 433).

\subsection{9. $18^{\text {th }}-19^{\text {th }}$ Century: Khanates and Emirates}

Already by the $17^{\text {th }}$ century, the Shaybanid Khanate had been weakened: Balkh was temporarily occupied by the Moghul Empire while Bukhara was attacked by Khiwa (Holzwarth 2005: 434). After a deep political and economic crisis from 1720-1770, the Uzbek empire disintegrated into several principalities (Holzwarth 2005: 434). Three new Uzbek dynasties subsequently emerged in the northern part of the former empire, which were able to re-establish political stability and economy (Holzwarth 2005: 435):

- Kokand Khanate: the Uzbek Ming separated from Bukhara and founded their capital in Kokand in 1740, countering the Kyrgyz tribes and the Dsungars there. They maintained good contacts with the Chinese who granted them privileges for their commerce with Kashgar. In addition, the Kokand Khanate which, apart from the Ferghana Valley, also con- 
trolled Tashkent, was an important mercantile partner for Russia (Holzwarth 2005: 435).

- Bukhara Emirate: the Mangyts regained control of Bukhara in 1750. Unlike their predecessors and neighbours, the Mangyts, "were not recognized as descendants of Genghis Khan and therefore could not bear the title of khans and were called amirs" (Naumkin 2005: 11). They emphasized the religious role of their political rule and tried to lead a disciplined lifestyle as a good example for their citizens. Some regarded themselves as mere followers of the Naqshbandiyah and refused any gaudiness. Again, Russia was an important trading partner for the $\mathrm{Bu}-$ khara Emirate, which was trying to regain its influence over Kokand and Khiwa (Holzwarth 2005: 435).

- Khiva Khanate: Khiva was the capital of Khwarezm. Here the nomadic life was more pronounced than in the other two dominions. Between 1742 and 1770 Turkmens and Uzbeks fought against each other, and finally the ruler (and since 1804 Khan) of the Uzbek Qungrat managed to gain suzerainty over the Turkmens (the latter separating only in 1855 when they became independent as the Tekke-tribes). Khiwa was well known as a centre of the slave trade - the city alone employed around 40,000 slaves (Holzwarth 2005: 435).

In the Khanates of Kokand and Khiva as well as in the Emirate of Bukhara, Hanafi Sunni Islam remained the official religion and throughout the region Sufi shaykhs retained a strong influence on politics (Naumkin 2005: 11). In the late $19^{\text {th }}$ century these last Uzbek empires were incorporated into tsarist Russia and later on became part of the Soviet Union. This meant that hundreds of years of Islam as (quasi) state religion - only interrupted during the rule of Genghis Khan - came to an end.

\subsubsection{0. $16^{\text {th }}-20^{\text {th }}$ Century: Russian Tsars}

The first Muslim territory to be occupied by the Russians was the land of the Tatars around Kazan in the $16^{\text {th }}$ century. What later became Kazakhstan was gradually incorporated into the Russian regime from the mid- $18^{\text {th }}$ century on. The Central Asian regimes also came under Russian control: the Emirate Bukhara in 1868, the Khiva Khanate in 1873, and Kokand Khanate in 1876. This means that the territory of today Kyrgystan, Tajikistan and 
Uzbekistan were incorporated into tsarist Russia in the late $19^{\text {th }}$ century (ARDA). This period was accompanied by resistance and strong repression against the local population: "The Kyrgyz staged a major revolt against the Tsarist Empire in 1916 in which almost one-sixth of the Kyrgyz population was killed" (ARDA: KG).

Literature about the tsarist period in Central Asia usually goes into details of the reigns of Peter I (reigned: 1682 - 1725) and Catherine the Great (reigned: 1762 - 1796). Whereas Peter I ruled very cruelly, Catherine the Great's politics were influenced by enlightened absolutism and allowed the Tatar Muslims not only ownership of land but also gave them the right to religious freedom under the 'Toleration of All Faiths' edict in 1773. Catherine the Great evoked the 'Orenburg Mohammedan Spiritual Assembly' in 1788 , headed by a mufti and established in Ufa for administering the affairs of the country's Muslims (Ro'i 2000: 100f). On the one hand, this had advantages for the Muslims who now were officially recognized and whose suppression was stopped (Yemelianova 2010: 19). On the other, the assimilation of Muslims into the state had advantages for the regime, too; for example, Muslim nomads were called upon to settle and were thereby easier to control (Ro'i 2000: 100f).

On the whole, the religious policies of the Russian tsars were ambivalent. Periods of relative religious freedom alternated with periods of forced assimilation and the curtailment of religious rights (Kappeler et al. 1989: 117). Or, as Schoeberlein puts it:

"The czarist policy toward Islam varied from highly suspicious, considering that fanatical Islam was the cause of uprisings against the czarist authorities, to tolerant and broadly supportive, reflecting the idea that Islam could be a civilizing factor, especially among nomads" (Schoeberlein: 2009. 100).

Compared to what was to come under communism, though, Russian tsars did not interfere too much in the religious life of Central Asians, who were allowed to operate their own religious schools and religious courts (Keller 2001). Tsarist Russia was primarily interested in Turkestan's natural resources (as cotton became increasingly important at the end of $19^{\text {th }}$ century), and in having a buffer area between itself and Great Britain during the 'Great Game' (1835 - 1840) (Keller 2001). 


\subsection{The Communist State and Islam in Central Asia}

\subsubsection{Bolshevik Revolution and the Central Asian Socialist Soviet Republics}

After the Revolutions of 1917, the Russians could not keep Central Asia in check. In Uzbekistan in particular, the Bolsheviks faced stiff resistance (ARDA: UZ). An outstanding role for the final communist conquest over Central Asia must be reserved for Frunze's efforts as a military leader of the Bolsheviks. Frunze, who originated from Bishkek (which was named after him from 1926-1991), was one of the most important military figures of the Civil War (Encyclopedia Britannica d). Not only did he lead the Eastern, Southern and Turkestan fronts of the Soviet Army but the Bukharan Emirate was also eliminated under his command (Frunse 1885-1925). Total control over the region was only fully reestablished in 1925 when the contemporary nation-states became terrirtorial and administrative entitites as Socialist Soviet Republics (SSR) (ARDA):

- Uzbekistan in 1924

- Tajikistan in 1929 (from 1925 on Tajikistan had been an Autonomous SSR inside the Uzbek SSR; with its transformation into its own SSR, "present-day Sughd province was transferred from the Uzbek SSR to the newly formed Tajik SSR in 1929" (ARDA: TJ).

- Kazakhstan in 1936

- Kyrgyzstan in 1936

The general effects of communism were felt most strongly by Central Asians through Soviet agricultural policies. During the 1920s and 1930s the collectivisation of agriculture and the forced settlement of nomads brought about a terrible famine which resulted in the death of around 1.5 to two million Kazakhs. Stalin's 'Virgin Lands' campaign in the 1950s and 1960s was another Soviet agricultural project with far-reaching consequences for Kazakhs:

“Soviet citizens were encouraged to help cultivate Kazakhstan's northern pastures. This influx of immigrants (mostly Russians, but also some other deported nationali- 
ties) skewed the ethnic mixture and enabled non-Kazakhs to outnumber natives" (ARDA: KZ).

Another well-known disaster in Central Asia, also unleased by Soviet agricultural policies, was the intensive production of cotton and grain. This "led to overuse of agrochemicals and the depletion of water supplies, which have left the land poisoned and the Aral Sea and certain rivers half dry" (ARDA: UZ). These negative developments, however, went hand in hand with the introduction of a modern education and health system and unforeseen infrastructural progress. Clearly the impact of Soviet politics on Central Asian life was immense; I will therefore not go into the general changes they brought about but will instead restrict my analysis to the religious policies under communism.

\subsubsection{Religious Policies under Communism}

Directly after the revolution in 1917 , the Soviet government paid little attention to the role of Islam. The Bolsheviks prioritized dealing with Christianity over Islam because Moscow's main religious problem seemed to be the Russian-orthodox church which tightly identified itself with the tsarist regime and was ingrained in the Russian population (Bräker 1989: 136). In addition, the Bolsheviks seemed to realize that Islam was the most important force shaping Central Asian society and therefore were reluctant to fight it for fear of antagonizing local people, whose main attitude was already anti-Russian. This meant that while all tsarist court systems were abolished by a law passed in 1917, the Muslim courts, which were acknowledged during the tsarist rule, persisted, "because authorities were afraid of adding to the already intense anti-Russian hostility" (Keller 2001: 31f). Furthermore, Moscow was a long way from Turkestan (how Central Asia was called in these times) and in the early years the infrastructure and resources for maintaining strict control over this region and abrogating Islam were not available (Keller 2001). In 1918 all waqf property was nationalized and sharia courts prohibited, however, the Soviet state was not yet able to provide education. In 1922 the nationalization was reversed and not only the religious schools but also sharia courts were permitted to operate legally again. Therefore, Central Asians practiced their religion quite freely notwithstanding the anti-religious communist ideology in the 1920s. How- 
ever, these relatively tolerant years did not last long, as Schoeberlein highlights:

"[...] after a period of relatively limited interventions in the decade following the Revolution, a very severe campaign was unleashed to suppress Islam. This was aimed primarily at transforming or liquidating those aspects of society in Central Asia and the Caucasus that were perceived as blocking the 'building of socialism', and all those identified as Islamic leaders were classified as the 'class enemy'" (Schoeberlein 2005: 100).

The destruction of Islamic traditions in the name of creating a socialist utopia included closing mosques, madrasas and maktabs. The religious élite was physically liquidated and local traditions concerning marriage, circumcision and burial were prohibited (Schoeberlein 2005: 100). The most severe repression of Central Asian Muslims took place under the anti-religion campaigns launched by Stalin and Khrushchev. Stalin fought against nationalist deviations, which included the practice of religion (Simon 1986: 14). One of the most terrible periods for Central Asians and nomads, who were among the most severely affected, was when Stalin welcomed or even consciously caused a famine to break the political will of non-Russian peoples (Simon 1986: 15) (see the 'Virgin Lands' campaign mentioned above).

During the Stalin and Khruschchev eras the transfer of Islamic knowledge by scholars as well as by representatives of folk Islam was interrupted:

"[...] under Stalin hundreds of people with both local and textual knowledge of Islam - pirs, shaikhs, ulama, Islamic intellectuals - were executed in a brutal attempt to break the connections of future generations with their Islamic past" (Vernon 2009: 280).

Islam was successfully suppressed from the public sphere and the physical presence of Islam was reduced by the destruction of mosques and madrasas (Khalid 2007: 2). Furthermore, many holy places were destroyed or converted into anti-religious museums (Bennigsen and Wimbush 1985: 132). People feared to visit the mosques or holy shrines because this could ruin their careers or "draw the unwanted attention of the government" (Vernon 2009: 280). Those who continued to visit the mazars in defiance of such 
risks were occasionally detained and as a consequence mazars were gradually abandoned (interview with Baktykan).

Yet the Soviet religious policy was not based on coercion alone (McGlinchey 2006). The very cruel politics alternated with periods of relative respite for Central Asian Muslims. ${ }^{3}$ Kappeler (1989) regards this as a continuity of the (alternately tolerant and repressive) religious policies of the tsars (Kappeler et al. 1989: 127). Especially during Second World War, the Soviet regime depended on the mobilization of the Muslim population and therefore made concessions to the practice of religion (Schoeberlein 2009: 100; Bräker 1989: 141). Religious activities and practices were once again permitted and the status of nomads was enhanced (Yemelianova 2010: 23). In this context, additionally to the TsDUM in Ufa, further religious administrations for Muslims were established such as the Spiritual Administration of the Muslims of Central Asia and Kazakhstan (SADUM). ${ }^{4}$ Indeed, the establishment of SADUM in Tashkent in 1943 represented, "a public admission of what had been apparent for several years - that the fight to eradicate Islam was over" (Keller 2001: 245).

The new official Islamic institutions took up some threads of the Jadidis. The Jadidis were Muslim reformers who had been active in Central Asia since the $19^{\text {th }}$ century and argued that modern education would improve the spiritual, economic and physical well-being of Muslims. Efforts were taken "to eradicate practices associated with Islam that were seen as being at odds with successful modernization, such as restrictions on women's roles, payment of bride-price in arranged marriages, and expensive celebrations associated with circumcision, marriage, and other community events" (Schoeberlein 2009: 105). These policies were complemented by solid measures in the social, educational and economic fields to integrate Muslims into the Marxist-Leninist system (Bräker 1989: 142). Although many Jadidis initially welcomed the Bolshevik revolution in the hope of social progress, they too soon became victims of the anti-religious campaigns.

3 At the same time, Muslims in other parts of the Soviet Union (Chechens, Kurds, Bulgarians) suffered collective deportation because they were accused of collaboration with Nazi Germany (Yemelianova 2010: 24).

4 Under communist rule, the Orenburg Mohammedan Spiritual Assembly in Ufa further persisted and was renamed Central Spiritual Directorate of the Muslims of Inner Russia and Siberia (TsDUM) (Ro'i 2000: 101). 


\subsubsection{Official Islam and Nationalization of Religion}

Under Soviet rule "an active atheism was pursued" (Naumkin 2005: 21). The majority of Central Asian mosques were destroyed or closed by the communists. Apart from small village mosques, which were effectively closed (Roy 2000: 152), very few mosques (around 300-400 for the whole Soviet Union) were registered with and declared legal by the Soviet administration (Ro'i 2000: 181). These mosques were allowed to operate but worship was restricted by SADUM which now represented the official Islam and also controlled Muslim education. The texts of the Muslim sermons had to be ratified in advance (Ro'i 2000: 255). Whereas registered mosques and the clergy were controlled by SADUM "at the same time shrine-based religious activities were denied any legal framework. [...] [The] Soviets took pains to demonstrate that shrine-based beliefs and practices were actually un-Islam" (Kehl-Bodrogi 2006: 235) and Sufi brotherhoods were persecuted (Naumkin 2005: 21).

Apart from the monitoring of Islamic content through SADUM, the authorities also specified political issues, such as economic restructuring programs, which had to be included in the sermon (Keller 1988). As the authorities depended on the imams to reach out to people, the official Islamic elite could take advantage of its position as an intermediary (McGlinchey 2006: 129). This gave the Muslim clergy, which could maintain its role after independence, relative autonomy:

“That the 'Soviet Muslim clergy' was not simply an extension of the Soviet ideological apparatus of KGB is evident in the diverse positions that these figures are now known to have taken in traditionalist versus reformist debates in Soviet times and the more open debates on these issues that are taking place in the post-Soviet period" (Schoeberlein 2009: 105).

Despite the strongly totalitarian religious policies of the communists, in practice the official clergy remained at least to some extent heterogeneous (see also Keller 2001). However, only those imams who cooperated fully with the Soviet authorities could be sure not to be replaced. Sometimes the registered clergy even perverted their faith to the extent that they could justify communist rule as the will of Allah, who sent Marx and Engels to at- 
tain socialism, arguing that communism corresponded with a righteous Muslim society (Ro'i 2000: 253f).

From the 1960s on Islam survived officially thanks to the new perception of religion as part of nationality: in the wake of national politics, religion, together with culture and ethnicity, was not only tolerated but even cultivated in a folkloristic way (Khalid 2007: 85ff). I will later on refer to these policies as the 'traditionalisation or nationalization of religion'. During this period even party members could describe themselves as Muslims, which implied that being Muslim was a cultural question and that it was even possible to be an 'atheist Muslim' (Pelkmans 2006). In order to promote the Soviet image in the Muslim world, students of Islamic theology were henceforth sent to friendly Sunni Arab countries for their studies (Roy 2000: 151). ${ }^{5}$ As a consequence of these relaxed religious policies, the revival of Islam started in the early 1980s. When the authorities realized this, they launched a "final large scale anti-Islamic campaign", which targeted “ 'popular religious practices', Islamic funeral rituals and what was labelled 'nationalist tradition', such as circumcision, marriage ceremonies and the practice of kalim (bride price)" (Kehl-Bodrogi 2006: 237). This phase lasted until the policies of glasnost and perestroika which were, after some delay, applied in Central Asia as in the rest of the Soviet Union (KehlBodrogi 2006: 237):

"At the end of the decade, the restrictions were largely lifted and the public display of Islamic religiosity became increasingly evident" (Kehl-Bodrogi 2006: 237).

\subsubsection{Central Asian Roots of Salafism}

The aforementioned contact with Sunni Arab countries (Libya, Syria, Egypt and Jordan), had an impact on the content of official Islam in the USSR:

"[...] young students of religion who were sent there came back deeply influenced by the thinking of the Muslim Brotherhood. These young ulemas displayed

5 This opening towards other Muslim regions had the unintended effect that some students were thereby influenced by the thinking of the Muslim Brotherhood (Roy 2000: 151). At any rate, they still collaborated with the authorities and remained loyal to the USSR (Roy 2000: 151). 
their political loyalty towards the USSR, but at the same time they were elaborating an uncompromising brand of Islam" (Roy 2000: 151).

They did not agitate against the Soviet rule but instead "played a long-term game of compromise with the authorities and re-Islamization of society" (Roy 2000: 151). Peyrouse explains that these young ulama, influenced by Arab political Islam, laid the foundations of Central Asian Salafism. He asserts that the present day revival of Salafi Islam has its roots in Soviet religious policies, and is primarily an indigenous development: "It was the Russian repression of reformist Islam leaders that led to the rise of fundamentalist Islam in the region during the Soviet period" (Peyrouse 2007: 40). Already at that time, the scripturalist Salafi Islam was contrasted by the government with Central Asian folk Islam (as we will see later on, only the roles ascribed to them by governments changed after independence). Whereas "in pre-Soviet Central Asia, the veneration of saints (avliyo) played a prominent role in Islamic piety", this "interrelation between mosque and shrine [...] became seriously disturbed" (Kehl-Bodrogi 2006: 235). Naumkin found out that in the 1980s the Salafis were supported by the communist party committees "in order to use them against the influential and therefore dangerous traditional Islam" and in order to divide the religious class (Naumkin 2005: 52). Sufism (and the Naqshbandiyah specifically) was declared 'parallel Islam' or even 'illegal Islam' because it was less institutionalized than scholarly Islam and therefore less tractable and more feared by the Soviet authorities (Bräker 1989: 134). ${ }^{6}$ Sunni and Shiite Islam, on the other hand, were usually summarized as official or institutionalized brands of Islam in Soviet literature (Bräker 1989: 134).

The impact of individuals' trips to Arab countries on the religious development of the region is especially apparent in the influence of the Babakhan family, who led SADUM from 1943-1957. Ishan Babakhan and after him, his son, Ziyauddin Babakhan were supreme muftis (Peyrouse 2007: 42f). Ziyauddin studied at al-Azhar University in Cairo and tried to present himself as a Hanafite, but returning from his first stay in the Middle East,

6 At any rate, there has always been a commingling between the two; "One should not imagine that Sufism in Central Asia is antagonistic with the scholarly Islam of the ulemas" (Roy 2000: 148). 
he brought with him many Hanbali publications. Furthermore, he opposed local traditions and customs, denouncing them as 'un-Islamic,' although he stemmed from a khoja family himself (Peyrouse 2007: 43). ${ }^{7}$ His fatwas, for instance, not only pointed out that "circumcision is not obligatory in the Quran," denounced "excessive expenditure occasioned by marriages and the dowry principle", and "criticized the cult of saint worship" (Peyrouse 2007: 43):

"His puritanism led him to regard the Central Asian traditions as superstitious practices contrary to the renewal of Islam. [...] His particular fundamentalist orientation, then, favoured a non-Hanafite re-Islamicization of the young Soviet generations. [...] Paradoxically, however, the political authorities preferred to support the fundamentalist theologians rather than the conservative elements and the Sufi movements [...]" (Peyrouse 2007: 44).

It was during the time of Ziyauddin Babakhan's leadership of SADUM that "the Muslims of Central Asia witnessed the beginnings of a schism between Hanafite conservatives and the newer, much more fundamentalist, informal movements influenced by Hanbalism and Shafiism" (Peyrouse 2007: 45).

When more tolerant religious policies were finally implemented under Gorbachev in late 1988 and early 1989, former mosques reopened and former parallel mullahs could overtly perform their tasks:

"[...] the parallel mullahs left their jobs in the kolkhoz (albeit keeping their plots of land), put on turbans and long robes and installed themselves in the mahalla mosques which were either reopening or were being built" (Roy 2000: 153).

Already by 19901,330 mosques were registered all over the USSR and the "number of madrasa students rose to several hundreds" (Yemelianova 2010: 27). During the last years of the Soviet Union, mullahs could decide more freely what they wanted to preach in their sermons and the former 'official Islam' of the Soviet Union was no longer so strictly defined.

7 For the explanation khoja of this term see section 2.4. 


\subsubsection{Unofficial Islam in the Soviet Union}

Although the repressive religious policies of the USSR were very broad, they were not totally successful or effective, as Keller states:

"A good part of the fault lay with the party itself, which too often issued vague, contradictory, and impossible-to-fulfil orders. However, at all levels of the Central Asian governing structure Muslims found ways to ignore orders that they deeply opposed (especially concerning women's status), turn a blind eye as clergy served on collective farms and evaded taxes, and make sure that their children understood the rudiments of religion. Convinced Communists, regardless of ethnic affiliation, were too few in number to stop this tide of evasion" (Keller 2001: xvf).

In short, the means to implement the theoretically totalitarian ideas of the communist party were often lacking. As Roy makes clear, the control of repression was "limited by the structure of the KGB itself: either it was local and complicit in what was going on, or it was town-based and unaware" (Roy 2000: 152). This may explain why Keller (2001) concludes that even under Stalin, the regime was not totalitarian in its practice (even if so theoretically). Further evidence for this is provided by Schoeberlein who writes that, "gathering at unofficial mosques, visitation of officially closed shrines, and the traditional life-cycle rituals although never officially accepted, were still maintained" (Schoeberlein 2009: 100). Shrines “ - museumized or not - remained focal points for popular Islam" (Louw 2007: 54). Yet it was in the area of non-institutionalized religious education that Soviet measures of eradication were particularly unsuccessful since such education, "depends more on a personal relationship with a teacher than an attachment to a religious or state institution" (Fathi 2011: 177).

So, despite Stalin's best efforts, an unofficial or 'underground' Islam persisted. Other reasons for the persistence of a parallel Islam include the fact that what was forbidden went underground, or the fact that the official clergy supported and was in contact with its unofficial counterpart:

"This official clergy was never cut off from the parallel clergy. Both came from the same environment: that of the provincial Sufi religious families. The official mullahs always had their initial education at the hands of the parallel mullahs. [...] The channels of communication have always been open, not least as a result of family 
and local links. The official mullahs who did not become muftis were sent to run the official mosque of their district of origin, where they re-established their old informal contacts with the parallel mullahs. The policy of the official mullahs was not to suppress the parallel clergy but to control it" (Roy 2000: 151).

Official and unofficial clergy often stemmed from the same khoja-families. The popular parallel Islam was represented by pirs, who still oversaw the Sufi shrines, and biotunchis, women who taught Islam in their private houses. As a consequence of the closure of most mosques during the Soviet period, especially in rural areas, people attended unregistered mosques, which were administered by parallel-mullahs (Schlageter 2003: 173). They met at traditional teahouses (chaykhana) or other non-religious public places (Yemelianova 2010: 25). I can conclude, then, that Islam remained important to the Central Asian people throughout the communist decades. (Yemelianova 2010: 25). As Yemelianova makes clear, this was particularly evident during celebrations of the main life-cycle events, such as births, circumcisions, marriages and deaths. 


\section{General Comparison of Contemporary Regimes}

All four Central Asian Republics became independent in 1991 as a result of the dissolution of the USSR. They did not have to struggle for their secession. In the absence of their own national liberation movements, their sovereignty resulted from the decisions of Jeltsin (Russia), Krawtshuk (Ukraine) and Schushkewitsch (Belarus) when they signed a document to dissolve the Soviet Union (Petric 2011: 166). As Matveeva makes clear, "With the break-up of the Soviet Union, independence was forced on Central Asian states rather than won by them" (Matveeva 1999: 24). In addition, although the Central Asian states were not founders of the Commonwealth of Independent States (CIS) on 8 December 1991, they immediately became members two weeks later on 21 December 1991.

Independence led to the emigration of many Russians from the Central Asian republics, most notably from Kazakhstan and, during the civil war, from Tajikistan. One consequence of emigration in these two countries was the effect it had on their economies. Borjian, referring specifically to Tajikistan, states that: "The rapid departure of Russians from the [Tajik] republic has resulted in a shortage of skilled labor, professionals, and industrial managers [...]" (Borjian 1997). By contrast, in Uzbekistan and Kyrgyzstan not only the economic but also the infrastructural situation has deteriorated since independence. For instance, it took Uzbekistan eleven years to achieve its 1989 production level, the first of the CIS states to do so, but even so and in spite of subsidized staple foods, many Uzbeks today still live below the poverty line (Schulze 2010: 52). 
Apart from economic and infrastructural problems, Kazakhstan, Kyrgyzstan, Tajikistan and Uzbekistan share institutional similarities which derive directly from their Soviet past. Indeed, the fact that the Soviet style of governance is still strong in all countries is an extremely important factor, not least because of the implications for regional identity, which as Matveeva points out, is "reflected in common political phenomena from referenda to extend presidential powers into the next millennium" (Matveeva 1999: 23), but also, as we shall see, since the national Muftiates are successor institutions of the Soviet SADUM.

All four countries are also currently concerned with developing both a cohesive national identity and countering security issues. Indeed, another commonality between these countries can be observed in the emergence of Islamic groups and states' reactions to them, which again can be attributed to their shared Soviet past. As we have already seen, Soviet ulama established contacts with Arab countries in the 1960s and brought 'foreign' interpretations of Islam to the region. Early Salafi groups had already started to appear during Soviet times and furthermore, the first political party based on Islam, the Islamic Renaissance Party (IRP) was founded during the reform years as an all-Soviet party under the presidency of Gorbachev (Roy 2000: 1; Schlageter 2003: 162). This resurgence of Islam has continued in the post-USSR era to the extent that today,

"[...] there is a strong impulse within the societies to assign a new importance to Islam as a guiding principle for changes in the social, political and moral order, in ways that will present challenges for both the traditional practice of Islam and the secular character of societies" (Schoeberlein 2009: 106).

The political leaders of the Central Asian countries, however, try to subdue political Islamic groups which challenge their position (Schoeberlein 2009: 106): “[ $[.$.$] they all pursue policies toward Islam that reflect a deep anxiety$ that it could become a powerful force opposing Soviet-style secularism and undermining the legitimacy of existing regimes" (Schoeberlein 2005: 98). Although in all countries more and more restrictive laws are being enacted, legacies and practices on the restriction of religious groups and political parties differ. I will elaborate on these differences in section 7.3 and present my typology of state restrictions on folk Islam and Salafi groups in chapter 9. 
This brings us to other differences which have emerged in the former Soviet republics since they became independent. What Matveeva wrote fifteen years ago has become even more true: "Today, the political development of the five Central Asian countries displays more diversity than uniformity, and Kazakhstan, Turkmenistan, Uzbekistan, Kyrgyzstan and Tajikistan are now distinct entities to a much greater extent than they were as Union Republics" (Matveeva 1999: 23). So whereas in Uzbekistan and Kazakhstan the former first secretaries of the Communist Soviet party were able to stay in power, Kyrgyzstan underwent several regime changes and a civil war raged in Tajikistan. Besides the differing political trajectories of these countries, developments in the social and economic domains and differences in the ethnic composition of the states suggest diverging conflict potentials. Concerning the issue of political Islam, I show that although there are various ways of dealing with the opposition and promoting wellcontrolled versions of Islam, in all societies illegal practices and groups still persist since constricted political freedom of choice leads to the problem that the opposition, which consists mainly of Islamists, establishes itself outside the state institutions (Khazanov 2005).

I will now compare issues regarded as relevant for social conflict by theories such as relative deprivation theory, social movement theory and political opportunity structure theory. The comparison in this sense is theory-led and presents considerations and information on conflicts in the region. In the first part of the next chapter I compare general aspects such as demography, ethnicity and the socio-economic situation as well as infrastructure and the political system of the Central Asian states.

In a more specific comparison, I afterwards concentrate on state institutions dealing with religion and the role of religion in the constitution. I then take a closer look at the religious laws of the contemporary governments and how they are implemented. Finally, I compare the security sectors of the Central Asian states according to factors such as domestic resources, international military aid and alliances. Although these latter aspects are more relevant for my study, the former more general comparison is important, as well, since it describes the context of the specific religious and security policies and what will be included in the computer simulation as contextlegitimacy of the state. 


\subsection{Demographic Situation}

\subsubsection{Demography}

The two smallest Central Asian countries, Kyrgyzstan and Tajikistan are at the same time the most mountainous and the ones with the smallest populations of 6 and 8 million, respectively. Uzbekistan is the Central Asian country with by far the biggest population of around 28 to 29 million people and the highest net-migration rate of -2.55 yet it has the lowest birth rate with 17.2 births per 1,000 populations as well as the lowest population growth rate $(0.94 \%)$. The most populous country after Uzbekistan is geographically the largest, Kazakhstan, which has around 15 to 18 million citizens. It has the highest median age of all Central Asian countries (29.5 years - this is still low by international standards; Switzerland's average age for example is 41.8). Furthermore, Kazakhstan is the only Central Asian country with more than $50 \%$ urban population and a positive net migration rate of 0.42 while Kyrgyzstan for instance shows a net migration rate of -7.13 . Tajikistan has the lowest average age at 23.2 as well as the lowest degree of urbanization with a percentage of only 26.5. Additionally, it shows the strongest migration to cities with an annual rate of $1.65 \%$. I will go into further details of work migration in section 6.2.3.

Table 3: Demographic Benchmarks

\begin{tabular}{|c|c|c|c|c|}
\hline & Kazakhstan & Kyrgyzstan & Tajikistan & Uzbekistan \\
\hline \multicolumn{5}{|l|}{ Population } \\
\hline Total population & 18 million & 6 million & 8 million & 29 million \\
\hline $\begin{array}{l}\text { Urban population } \\
\text { in } \% \text { of } \\
\text { total population }\end{array}$ & 53.6 & 35.5 & 26.5 & 36.2 \\
\hline \multicolumn{5}{|l|}{ Age structure } \\
\hline $15-24$ years in $\%$ & 16.9 & 19.4 & 20.4 & 21.1 \\
\hline Median age & 29.5 & 25.4 & 23.2 & 26.6 \\
\hline
\end{tabular}




\begin{tabular}{|l|l|l|l|l|}
\hline \multicolumn{2}{|l|}{ Population growth } & 23.67 & 25.49 & 17.2 \\
\hline $\begin{array}{l}\text { Birth rate per 1,000 } \\
\text { of population }\end{array}$ & 20.03 & 0.97 & 1.79 & 0.94 \\
\hline $\begin{array}{l}\text { population growth } \\
\text { rate in \% }\end{array}$ & 1.2 & -7.13 & -1.19 & -2.55 \\
\hline $\begin{array}{l}\text { Net migration rate } \\
\text { per 1,000 } \\
\text { of population }\end{array}$ & 0.42 & & & \\
\hline
\end{tabular}

Source: CIA World Factbook (2012)

\subsubsection{Ethnicity}

The biggest Russian minority in the Central Asian states today lives in Kazakhstan, where they amount to over $23 \%$ of the population and mainly live in the north of the county. Kazakhstan is the only state where the titular nation constitutes only just over half of the population (ARDA: KZ). This was not always the case but has only become so recently as a result of state's successful efforts to entice significant numbers of ethnic Kazakhs living abroad back to their homeland by means of economic incentives (interviews with Indira Burnashev).

Significant numbers of ethnic minorities can also be found in Kyrgyzstan, where ethnic Uzbeks living mainly in the south of the country constitute $14 \%$ of the population, and Tajikistan, where ethnic Uzbeks living mainly in Sughd province make up around $15 \%$ of the population.

These areas with significant minorities are most prone to ethnic conflicts. The most recent example of this was the 2010 conflict in Osh, where around 420 people lost their lives (ICG 2012). It is still debatable what influence Islam had on this conflict. Even if it did play a minor role, it was undoubtedly the representation of Uzbeks in Kyrgyz society which was the main factor. Uzbeks claim that they are underrepresented in the national government. Kyrgyz on the other hand take issue with Uzbeks for having a monopoly in the business sector. Uzbeks in the south not only feel marginalized and forced out of public life, they also suffer concrete discrimination, as ICQ point out: 
"[...] most Uzbek-language media have been closed; [...]. International organisations report continuing persecution of Uzbeks by a rapaciously corrupt police and prosecutorial system, almost certainly with the southern authorities' tacit approval" (ICG 2012: i).

The reference to ethnic identity in politics became a more significant issue after independence due to the partially arbitrary demarcation between the former Soviet Republics. Discrimination based on ethnic origins is not only a problem in Kyrgysztan, but takes place in Kazakhstan against Russians (Freedom House 2013 a) and in Uzbekistan against Tajiks. In Uzbekistan, for example:

"The belief that senior positions in government and business are reserved for ethnic Uzbeks is widespread. Moreover, the government appears to be systematically closing schools for the Tajik-speaking minority" (Freedom House 2013 d).

It is questionable how far ethnic differences were a primary source of conflict in South Kyrgyzstan or if they were rather instrumentalized by stakeholders to mobilize the masses in the conflict. It is important to note that data about the ethnic composition of the Central Asian societies are used and misused as a political instrument and therefore should be carefully dealt with. This holds true also for the data presented in Table 4.

Table 4: Ethnic Composition of Central Asian Societies

\begin{tabular}{|l|l|l|l|l|}
\hline & Kazakhstan & Kyrgyzstan & Tajikistan & Uzbekistan \\
\hline Ethnicity & 63\% Kazakhs & $65 \%$ Kyrgyzs & $80 \%$ Tajiks & $80 \%$ Uzbeks \\
& $24 \%$ Russians & $14 \%$ Uzbeks & $15 \%$ Uzbeks & $6 \%$ Russians \\
& & $13 \%$ Russians & $1 \%$ Russians & $5 \%$ Tajiks \\
& & & $1 \%$ Kyrgyzs & $3 \%$ Kazakhs \\
\hline
\end{tabular}

Source: CIA World Factbook (2012)

\subsubsection{Religion in Society}

A strong correlation between ethnicity and religion exists in Central Asia. Ethnic Russians usually belong to the Orthodox or another Christian 
church, which makes Christianity the second biggest religious community in all of the four Central Asian countries after Islam (see Table 5).

Table 5: Religious Composition: Muslims and Christians

\begin{tabular}{|l|l|l|l|l|}
\hline & Kazakhstan & Kyrgyzstan & Tajikistan & Uzbekistan \\
\hline Muslims in \% & $70 \%$ & $75 \%$ & $90 \%$ & $88 \%$ \\
\hline Christians in \% & $26 \%$ & $20 \%$ & No data & $9 \%$ \\
\hline
\end{tabular}

Source: CIA World Factbook (2012)

The ethnic origin of a person can also often reveal the madhab he or she adheres to. The Shafi'i Muslims living in Kazakhstan, for example, are usually Chechens (ARDA: KZ).

There are regional differences in the adherence or devotion to religion. In every country there are certain regions which are regarded as especially religious, such as the Fergana Valley in Uzbekistan or the area around Shymkent in south Kazakhstan. Salafis, becoming more numerous in recent years in Tajikistan (in the whole country there are around 5,000 according to government estimates) are most prevalent in Dushanbe, Sughd, and Khatlon (ARDA: TJ). Finally, in Kyrgyzstan "religious practice in the south is more traditional and devout than in other regions" (ARDA: KG). This observation is linked to ethnicity, as well, as many Uzbeks live in the south of Kyrgyzstan as well as in the south of Kazakhstan.

Due to SADUM's headquarters being in Tashkent, Uzbeks have for a long time played a leading role in religious affairs throughout the region. During Soviet times, the SADUM “administration's staff was made up almost exclusively of Uzbek clergy and all correspondence was conducted in Uzbek" (Rotar 2004a). As a result, Ponomarev and Jukeyeva claim that in 1989 most imams in Kazakhstan were non-Kazakhs, the majority of whom were Uzbeks (Ponomarev and Jukeyeva cited in Rotar 2004a). This changed only after independence when a "deliberate displacement of ethnic Uzbeks from their positions as imams at mosques began" (Rotar 2004a). In addition to being the seat of SADUM, Uzbekistan still retains its importance within Islam today as the main historical Islamic cities are located on its territory. 
As Table 5 further shows, in Tajikistan and Uzbekistan 9 out of 10 people are Muslims - the biggest percentages among the Central Asian states. At the same time, Tajiks and Uzbeks are said to practice their religion more actively than Kazakhs and Kyrgyzs, as Rotar (2004b) makes clear: "Most devout Muslims in Central Asia are ethnic Uzbeks and Tajiks". This is usually explained with the assumption that the originally sedentary populations are more devout than the 'superficially Islamized' nomads (see section 5.1). My interviewees generally also stated that the Tajik and the Uzbek populations are 'more religious' than the Kazakh and Kyrgyz people and my own observations affirmed this - in Tajikistan in particular I met many more people performing the mandatory five prayers a day than in the other countries.

Even so, I challenge the widespread opinion that particularly the Muslim populations of Kazakhstan and Kyrgyzstan constitute only "nominal believers" who "do not practice their faith actively" (ARDA: KG), and who "call themselves Muslims [but] drink alcohol, do not fast in the month of Ramadan and hardly ever attend mosque" (Rotar 2004b). As I show in section 9.1, the religious policies of the Central Asian states have had a significant impact on the practice of religion and on the attendance of religious services; for example, more scripturalist interpretations of Islam and religious worship have spread among Kyrgyzs while these have become less popular in Uzbekistan.

Demographic factors also play a role in the religiosity of the local population: in Tajikistan it is particularly city residents and young people under the age of 20 who are becoming more observant (ARDA: TJ). This is also the case in Uzbekistan:

"Outside of Tashkent, practicing Muslims outnumber non-practicing Muslims [...] mosque attendance continued to increase, particularly among younger men, who constitute the majority of worshipers" (ARDA: UZ).

In Kyrgyzstan, however, I observed that especially older people were becoming more devout - a phenomenon that is known in Europe as well. 


\subsection{Socio-economic Situation}

\subsubsection{Natural Resources, Energy and Infrastructure}

The economic situation of the Central Asian states is very diverse. Kazakhstan, for example, is an exceptional case; its GDP per capita is much higher than in other Central Asian countries. Whereas Kazakhstan GDP amounts to $\$ 14,100$, the GDP of Uzbekistan is $\$ 3,600$, Kyrgyzstan $\$ 2,400$ and Tajikistan $\$ 2,300$ respectively. Recently Kazakhstan has become especially concerned with the expansion and exportation of its energy resources as well as with the diversification of the economy outside the energy sector (ARDA: KZ). Not only the country's vast natural resources but also its relative political stability give Kazakhstan an economic advantage over its Central Asian neighbours (ARDA: KZ). Apart from Kazakhstan, Uzbekistan is another main energy producer of the region: while the former holds eighteenth place in the country comparison for crude oil production the latter holds fifteenth place in the country comparison for natural gas production.

Export Commodities (CIA World Factbook):

- Kazakhstan: oil and oil products, natural gas, ferrous metals, chemicals, machinery, grain, wool, meat, coal

- Kyrgyzstan: gold, cotton, wool, garments, meat, tobacco, mercury, uranium, electricity, machinery, shoes

- Tajikistan: aluminium, electricity, cotton, fruits, vegetable oil, textiles

- Uzbekistan: energy products, cotton, gold, mineral fertilizers, ferrous and nonferrous metals, textiles, food products, machinery, automobiles

Table 6: Economic Benchmarks

\begin{tabular}{|l|l|l|l|l|}
\hline & Kazakhstan & Kyrgyzstan & Tajikistan & Uzbekistan \\
\hline Economy & 5.0 & -0.9 & 7.5 & 8.2 \\
\hline $\begin{array}{l}\text { GDP real growth rate } \\
\text { in } \%\end{array}$ & & & \\
\hline
\end{tabular}




\begin{tabular}{|c|c|c|c|c|}
\hline $\begin{array}{l}\text { GDP per capita in } \$ \\
\text { (country comparison) }\end{array}$ & $\begin{array}{l}14,100 \\
(95)\end{array}$ & $\begin{array}{l}2,400 \\
(185)\end{array}$ & $\begin{array}{l}2,300 \\
(189)\end{array}$ & $\begin{array}{l}3,600 \\
(171)\end{array}$ \\
\hline \multicolumn{5}{|l|}{ Energy } \\
\hline $\begin{array}{l}\text { Crude oil production in } \\
\text { bbl/day } \\
\text { (country comparison) }\end{array}$ & $\begin{array}{l}1,635,000 \\
(18)\end{array}$ & $\begin{array}{l}1,000 \\
(98)\end{array}$ & $\begin{array}{l}215 \\
(100)\end{array}$ & $\begin{array}{l}104,400 \\
(49)\end{array}$ \\
\hline $\begin{array}{l}\text { Natural gas production } \\
\text { in million cu m } \\
\text { (country comparison) }\end{array}$ & $\begin{array}{l}20,200 \\
(33)\end{array}$ & $\begin{array}{l}12.5 \\
(90)\end{array}$ & $\begin{array}{l}40 \\
(85)\end{array}$ & $\begin{array}{l}62,900 \\
(15)\end{array}$ \\
\hline
\end{tabular}

Source: CIA World Factbook (2012)

However, the most important economic sectors are conflict-prone. As the income from the energy sector in Kazakhstan, for example, makes up two thirds of the national budget (Schulze 2010: 33) it is hardly surprising that the state does not respond kindly to disruptions to oil production. In December 2012, after more than six months, an oil-workers' strike against Usenmunaigas (affiliated company of Kazmunaygas) in Zhanaozen turned bloody. During the celebration of Kazakhstan's independence, protestors set fire to administration buildings and the oil company's headquarters. The police responded with lethal force. Officials state that 16 people were killed and around 100 injured, however correct numbers might be higher (Bensmann 2012: 7). ${ }^{1}$ Similarly, in Kyrgyzstan, the exploitation of the most important export-product, gold, also led to protests.

"The protests against the operations of the Kumtor gold mine (which generates 12\% of Kyrgyzstan's GDP) in the Issyk-Kul district in the north of the country, continued until 3 June and resulted in 50 people being injured. The protesters demanded to be paid damages for the destruction of the environment caused by gold mining and to have social allowances increased for miners (the mine is now the property of the Canadian company Centerra Gold)" (Lang 2012).

1 See also Amnesty International report: http://www.amnesty.org/en/for-media/ press-releases/kazakhstan-no-accountability-entrenched-torture-2013-07-11. 
The Krygyz conflict concerning the conditions for gold exploitation are between Kyrgyz citizens and an international private company. Yet in contrast to the Kyrgyz case, in Kazakhstan and Uzbekistan the companies exploiting natural resources are still in the hands of the state. This is also true of Uzbekistan's second most important export product: cotton. International observers regularly criticize the government policy of forced cotton harvest among school children (Antonikis 2012). ${ }^{2}$ In recent years though, the government has sought to "[...] gradually lessen its dependence on agriculture while developing its mineral and petroleum reserves" (ARDA: UZ). Also in the poorest of the former Soviet countries, Tajikistan, the main export company is state run: the Aluminium company Talco. It is directly controlled by President Rahmon and was criticized by the International Monetary Fund (IMF) for "most worrisome financial operations [which] remain nontransparent" (Helmer 2008).

Economic problems have become more conflict-prone since independence:

"As part of the Soviet Union, the five countries were tightly woven into a single system. These interdependencies have proven difficult to unravel, and have produced serious imbalances. During the Soviet era, the countries were obliged to work together. Now they no longer have to get along, and usually do not, especially as far as energy is concerned" (ICG 2011).

Several exclaves were formed when the Soviet Union dissolved, especially in the Ferghana valley. This still occasionally leads to territorial disputes, for example the conflict in Batken Oblast, an Uzbek exclave in Kyrgyzstan (Wechlin 2013). As recent events have shown, infrastructural problems often serve as triggers for such disputes: in January 2013, in the village of Hoshjar around 40 Kyrgyz were taken hostage and cars destroyed because a high-voltage mast was erected on the territory of the enclave (ZA 2013: 28). This shows how easily violence can erupt in a conflict-prone environment. Violence has flared up in such situations not only between populations and governments but also between states: in January 2014 a border dispute between Kyrgyzstan and Tajikistan led to many casualties on both

2 For an official Uzbek statement about cotton production see: http://www. gov.uz/en/helpinfo/agriculture/10020. 
sides - again, the main trigger seemed to be the energy supply of a Tajik enclave situated in Kyrgyzstan:

"Tajik forces fired mortars at a water pump. Kyrgyz authorities fear this may be just the opener in a series of strikes on strategic water facilities along the disputed border with Tajikistan. As the population along the Kyrgyz-Tajik border grows the risk is greater than ever that a local dispute over resources could rapidly become an international crisis" (Dalbaeva 2014).

Apart from inter-state problems, energy supply and the poor infrastructural situation are other major possible causes of unrest in the Central Asian states. The International Crisis Group even offers Kyrgyzstan's poor economic situation as an explanation for the overthrow of President Bakiyev in 2010 (ICG 2011); I present the more specific conditions of the political Central Asian systems in section 6.3.

\subsubsection{Poverty}

Indeed, Tajikistan, was already the poorest Central Asian republic during Soviet times and therefore profited in a special way from inner-Soviet economic assistance. As such, since the break-up of the Soviet Union its economy has suffered disproportionately, as Borjian explains: "In many factories production has decreased dramatically or even ceased, owing to interruption in imports of raw materials and to fuel shortages" (Borjian 1997). Therefore, "the country remains the poorest in the former Soviet sphere" (ARDA: TJ). Due to NATO intervention in neighbouring Afghanistan, the country receives a significant number of international visitors as well as military and economic assistance (ARDA: TJ). Yet despite this Tajikistan still has the highest percentage of the population living under the poverty line (39.6\%). It is followed by Kyrgyzstan (33.7\%), Uzbekistan (17\%) and Kazakhstan $(5.3 \%)$. It is important to note, though, that these figures are estimates. Neither are the unemployment rates in the following table of great value since they are official rates, which are not reliable. In Uzbekistan, for example: 
"[...] the government's statistical agency said the unemployment rate had fallen to under 4.8 per cent of the able-bodied population. The World Bank, meanwhile, puts the figure at between 20 and 30 per cent, varying across the country" (IWPR 2013a).

In order to have at least some indication of the economic situation in these countries, I present here the most reliable estimates.

Table 7: Poverty Benchmarks

\begin{tabular}{|l|l|l|l|l|}
\hline & Kazakhstan & Kyrgyzstan & Tajikistan & Uzbekistan \\
\hline $\begin{array}{l}\text { Population below } \\
\text { poverty line in \% }\end{array}$ & 5.3 & 33.7 & 39.6 & 17.0 \\
\hline $\begin{array}{l}\text { Unemployment rate } \\
\text { in \% }\end{array}$ & 5.3 & $\begin{array}{l}8.6 \\
(2011)\end{array}$ & $\begin{array}{l}\text { (officially; } \\
\text { in reality } \\
\text { much } \\
\text { higher) }\end{array}$ & $\begin{array}{l}\text { (officially) } \\
20-30 \% \\
\text { (WTO) }\end{array}$ \\
\hline $\begin{array}{l}\text { Distribution of Family } \\
\text { Income - GINI- Index } \\
\text { (Social stratification) }\end{array}$ & 28.9 & 33.4 & 32.6 & 36.8 \\
\hline
\end{tabular}

Source: CIA World Factbook (2012)

For relative deprivation theory (which explains conflicts by deprivation deriving from unequal distribution), even more interesting than the percentage of people living under the poverty line is the Gini index. It measures the distribution of wealth with a value between 0 and 1 , whereby 1 means a perfect unequal distribution. I will here have a look at the distribution of family income with an index elaborated by the CIA World Factbook based on the Gini Index. This index measures the degree of inequality in the distribution of family income in a country:

"If income were distributed with perfect equality, the Lorenz curve would coincide with the 45 degree line and the index would be zero; if income were distributed with perfect inequality, the Lorenz curve would coincide with the horizontal axis and the right vertical axis and the index would be 100" (CIA World Factbook 2012). 
A clearer indicator than mere unemployment rates and the Gini Index, this Index of family income shows how Central Asian citizens are affected by the unequal distribution of economic resources. The index reveals that the income of families is most unequal in Uzbekistan, whose economy has stagnated in recent years, followed by Kyrgyzstan, Tajikistan and Kazakhstan in this order. These findings coincide with my own impressions in the field. Whereas in Kazakhstan at least some trickle-down effect is observable in the cities of Astana and Almaty, in Uzbekistan - although it has the second highest GDP per capita - not much wealth seems to reach the general population. However, even in Kazakhstan, where the best distribution is observed, a great conflict potential lies in the problem of social stratification (Schoeberlein 2009: 106). Despite the impression that the Kazakh state is often able to buy off its people, here too there is a growing discontent among its citizens (interview with a member of OSCE in Almaty).

\subsubsection{Migrant Labour}

Many poor individuals emigrate to Russia from the Central Asian countries in search of work to improve their own and their family's economic situation. In Tajikistan, the remittances of migrant workers constitute almost half its GDP. Not only people from Tajikistan, but also many from Kyrgyzstan and Uzbekistan head for Russia, where "some stay only for seasonal work, while others settled down semi-permanently" (IWPR 2013a). Experts estimate that Uzbekistan "has lost 2 to 3 million [citizens] in recent years due to the growing trend of labor migration to neighboring countries, particularly Russia and Kazakhstan" (ARDA: UZ). For this reason, travel constraints have been implemented to prevent Uzbeks from seeking employment abroad - they need for example an exit visa, which is often issued selectively (Freedom House 2013d). Overall, 70 to $80 \%$ of all Kazakh, Kyrgyz and Tajik migrants move to Russia (UNECE 2012: 7). They often reside illegally and official figures might be much too low as is shown in Table 8. Moreover, since "the early 2000s, [...] labor migration has been growing steadily" (Anichkova 2012). Occasionally, migrant workers are regarded as especially prone to extremist proselytizing efforts as they are cut off from their families and find themselves in difficult economic circumstances (Vinson 2013), however, to deal with this issue here goes beyond the scope of my study. 
Table 8: Numbers of Migrant Workers Abroad

\begin{tabular}{|l|l|l|l|l|}
\hline & Kazakhstan & Kyrgyzstan & Tajikistan & Uzbekistan \\
\hline \multicolumn{2}{|l|}{ Remittances of migrant workers } & $27-29 \%$ & $49 \%$ & $10-13 \%$ \\
\hline $\begin{array}{l}\% \text { of GDP } \\
\text { (Anichkova 2012) }\end{array}$ & - & 300,000 & - & 250,000 \\
\hline Estimations of numbers of migrant workers by different sources & \\
\hline $\begin{array}{l}\text { Official figures } \\
\text { (2004 - 2008) } \\
\text { (Anichkova 2012) }\end{array}$ & - & 800,000 & 1.5 million & 3 million \\
\hline $\begin{array}{l}\text { Estimations by } \\
\text { Anichkova } \\
\text { (Anichkova 2012) }\end{array}$ & - & - & - & 5 million \\
\hline $\begin{array}{l}\text { Najot human rights } \\
\text { group } \\
\text { (see IWPR 2013a) }\end{array}$ & - & & & \\
\hline
\end{tabular}

The Central Asian states are members of different international economic organizations. Kyrgyzstan was the first Central Asian country to join the WTO in 1998; the others walled off their domestic markets until recently (Schulze 2010: 66). Tajikistan was the second country to join in March 2013. While Uzbekistan applied for membership to the World Trade Organization in 1994, and Kazakhstan in 1996, neither have yet become members (WTO 2013). Other international economic organizations include the Eurasian Economic Community (EURASEC) which was founded in 2001 by Russia, Belarus, Kazakhstan, Kyrgyzstan and Tajikistan in order to decrease duties among member countries.

\subsubsection{International Trading Partners}

It is important to note Central Asian states' international trading partners because some of them also play an important role in the security sector. As we see in Table 9 China, with around $20 \%$, is the biggest export partner of 
both Uzbekistan and Kazakhstan. Kyrgyzstan and Tajikistan on the other hand export less than $10 \%$ to their Chinese neighbour, but import a lot more products from there - around 55\% of Kyrgyz imports and $42 \%$ of Tajik imports come from China. While Russia does supply "Kyrgyzstan with petrol products duty free" (Rickleton 2013b), a much higher percentage of Kazakhstan and Uzbekistan's imports come from Russia than their smaller neighbour. China is therefore Kazakhstan and Uzbekistan's second most important import partner after Russia.

Kazakhstan seems to be the most important trading partner for its Central Asian neighbours (probably primarily with oil), whereas Turkey is the most significant export partner to Tajikistan and to a lesser degree is important as an import partner to Uzbekistan and Kyrgyzstan. Iran has become a key contractor of assisted infrastructure projects in Tajikistan, for example of Sangtuda-2 hydropower plant (Freedom House 2013c). China also plays an important role in Central Asia in the domain of infrastructure building.

Table 9: International Trading Partners

\begin{tabular}{|c|c|c|c|c|}
\hline & Kazakhstan & Kyrgyzstan & Tajikistan & Uzbekistan \\
\hline $\begin{array}{l}\text { Membership } \\
\text { in WTO } \\
\text { (WTO) }\end{array}$ & no & yes & yes & no \\
\hline $\begin{array}{l}\text { Membership } \\
\text { EURASEC } \\
\text { (EURASEC) }\end{array}$ & yes & yes & yes & no \\
\hline $\begin{array}{l}\text { Exports } \\
\text { Partners } \\
\text { (CIA World } \\
\text { Factbook } \\
2012 \text { ) }\end{array}$ & $\begin{array}{l}\text { China } 21 \% \\
\text { Russia } 9.9 \% \\
\text { France } 9.3 \% \text {, } \\
\text { Germany } \\
6.9 \% \\
\text { Italy } 5 \% \\
\text { Canada } 4.8 \% \\
\text { Ukraine } 4.7 \% \\
\text { Romania } 4.1 \%\end{array}$ & $\begin{array}{l}\text { Uzbekistan } \\
28.8 \% \\
\text { Kazakhstan } \\
22 \% \\
\text { Russia } 14.6 \% \\
\text { China } 7 \% \\
\text { UAE } 6.3 \% \\
\text { Afghanistan } \\
5.7 \%\end{array}$ & $\begin{array}{l}\text { Turkey } \\
30.5 \% \\
\text { China } 9.6 \% \\
\text { Iran } 7.7 \% \\
\text { Afghanistan } \\
6.5 \% \\
\text { Kazakhstan } \\
4.9 \% \\
\text { Russia } 4.3 \%\end{array}$ & $\begin{array}{l}\text { China } 18.5 \% \\
\text { Kazakhstan } \\
14.6 \% \\
\text { Turkey } 13.8 \% \\
\text { Russia } 12.8 \% \\
\text { Ukraine } \\
12.5 \% \\
\text { Bangladesh } \\
8.9 \%\end{array}$ \\
\hline
\end{tabular}




\begin{tabular}{|l|l|l|l|l|}
\hline Imports & Russia 31.6\% & China 55.9\% & China 42.3\% & Russia 20.6\% \\
Partners & China 26.6\% & Russia 17.7\% & Russia 16.2\% & China 16.5\% \\
(CIA World & Germany 6\% & Kazakhstan & Kazakhstan & South Ko-rea \\
Factbook & Ukraine 4.4\% & $6.4 \%$ & $10.1 \%$ & $16.3 \%$ \\
2012) & & & Turkey 5.7\% & Kazakhstan \\
& & & Iran 4.2\% & $12.8 \%$ \\
& & & & Germany \\
& & & & $4.6 \%$ \\
& & & & Turkey 4.2\% \\
\hline
\end{tabular}

\subsubsection{Social Infrastructure: Health and Education}

I am interested in the infrastructure the states are able to provide and maintain owing to the major contribution this makes to the living standards of ordinary people, a factor that theories such as relative deprivation refer to, and which will be considered in the simulation as context-legitimacy.

Health expenditures range from $4.3 \%$ in Kazakhstan to $6.2 \%$ in $\mathrm{Kyr}$ gyzstan. Countries with a smaller GDP therefore spend a proportionally higher amount on health services. There are fewer physicians in the poorer countries of Tajikistan and Kyrgyzstan, which have only a little over 2 physicians per 1,000 people, while Kazakhstan has both the highest physician density (3.88 per 1,000) and the highest hospital bed density at 7.6 per 1,000. However, the other countries, which have about one bed for 200 people, have the same rate as countries with developed economies such as Switzerland.

The high hospital bed density might be a consequence of the Soviet health system. However, the entire infrastructure was inherited from the Soviets and since independence the health and education sectors have suffered in all Central Asian countries (ICG 2011). ${ }^{3}$

3 For further reading on health services see McKee, Martin; Healy, Judith, Falkingham, Jane (ed.) (2002): Health Care in Central Asia. European Observatory on Health Care Systems. World Trade Organization. Buckingham: Open University Press. Availalbe at: http://www.euro.who.int/_data/assets/pdf_file/0007 198386/E74484.pdf (2.2.2014). 
"The quality of education and healthcare has plummeted with the end of the social safety net. In some countries, notably Kyrgyzstan and Tajikistan, these sectors have almost ceased to exist" (ICG 2011).

In the educational domain, Kyrgyzstan stands alone with an expenditure of $5.8 \%$ of GDP, whereas Kazakhstan shows a percentage of 3.1 and Tajikistan 3.9. No data is available for Uzbekistan. The school life expectancy in all countries amounts to 12 years, except for in Kazakhstan, where it lies three years above this average.

Table 10: Infrastructural Benchmarks

\begin{tabular}{|c|c|c|c|c|}
\hline & Kazakhstan & Kyrgyzstan & Tajikistan & Uzbekistan \\
\hline \multicolumn{5}{|l|}{ Health } \\
\hline $\begin{array}{l}\text { Health } \\
\text { Expenditures } \\
\text { in } \% \text { of GDP }\end{array}$ & 4.3 & 6.2 & 6.0 & 5.3 \\
\hline $\begin{array}{l}\text { Physicians } \\
\text { per 1,000 } \\
\text { population }\end{array}$ & 3.88 & 2.3 & 2.01 & 2.62 \\
\hline $\begin{array}{l}\text { Hospital bed } \\
\text { density per } \\
1,000 \\
\text { population }\end{array}$ & 7.6 & 5.06 & 5.2 & 4.6 \\
\hline \multicolumn{5}{|l|}{ Education } \\
\hline $\begin{array}{l}\text { Education } \\
\text { expenditures } \\
\text { in } \% \text { of GDP }\end{array}$ & 3.1 & 5.8 & 3.9 & No data \\
\hline $\begin{array}{l}\text { School life } \\
\text { expectancy } \\
\text { in years }\end{array}$ & 15 & 12 & 12 & 12 \\
\hline
\end{tabular}

Source: CIA World Factbook (2012) 
In a nutshell, the Human Development index measures health, education and living standards at an aggregate level. The indicators which the index includes are life expectancy at birth (for measuring health), mean years and expected years of schooling (for education) and gross national income per capita (for living standards). Predictably, Kazakhstan shows the highest level of human development. This country was able to improve its social, educational and health systems owing to its income from the energy sector (Schulze 2010: 33). It is followed by Uzbekistan with Kyrgyzstan and Tajikistan receiving the lowest measures. Nevertheless, we should keep in mind that "a country's overall index can conceal the fact that different groups within the country have very different levels of human development" (HDI). In particular, Uzbekistan gets a better rating than Kyrgyzstan and Tajikistan because of its higher GDP, though this is very unequally distributed. Therefore this measurement should be used cautiously in this case. I will therefore combine HDI with the Gini-Index of family income when developing my own indicator for the context-legitimacy of the Central Asian states in section 11.2.2.

Table 11: Human Development Index

\begin{tabular}{|l|l|l|l|l|}
\hline & Kazakhstan & Kyrgyzstan & Tajikistan & Uzbekistan \\
\hline $\begin{array}{l}\text { Human } \\
\text { Development } \\
\text { Index (HDI) }\end{array}$ & 0.754 & 0.622 & 0.622 & 0.654 \\
\hline
\end{tabular}

According to the International Crisis Group, the poor infrastructural situation is a possible source of unrest and could even serve to bolster Islam:

"The rapid deterioration of infrastructure will deepen poverty and alienation from the state. The disappearance of basic services will provide Islamic radicals, already a

4 "The first Human Development Report introduced a new way of measuring development by combining indicators of life expectancy, educational attainment and income into a composite human development index, the HDI." See http://hdr.undp.org/en/statistics/hdi/. 
serious force in many Central Asian states, with further ammunition against regional leaders and openings to establish influential support networks" (ICG 2011).

I agree with this assessment of ICG. As I showed in part I of this study, Islamists take up social and economic problems in their political debates.

\subsection{Political System and Government Bodies}

I will now take a closer look at the government bodies and political institutions of the independent Central Asian states.

\subsubsection{Political Systems and Presidents}

All Central Asian states started in the early 1990s with a presidential system. Since the second regime change in 2009 and the coming into force of the new constitution in 2010 making it a parliamentary republic, Kyrgyzstan has been the only exception. In all Central Asian countries the president is elected directly by the people. Initially, the former first secretaries of the Communist Party in the Central Asian republics became the presidents of the newly independent republics. Since there was no other elite in these countries than the one established by the Soviets this is not surprising (Khazanov 2005: 21). The first presidents in Central Asia were Nursultan Nazarbaev in Kazakhstan, Askar Akaev in Kyrgyzstan, Rahmon Nabiev in Tajikistan and Islam Karimov in Uzbekistan.

Nazarbaev and Karimov are still in power today. The last presidential elections they won were held in 2011 Kazakhstan and in 2007 in Uzbekistan yet neither Nazarbaev, nor Karimov have ever won an election that was regarded as free by international observers. Both presidents are accused of fabricating the election results and amending the constitutions to prolong their terms of presidency. In the 2007 Kazakh constitution, for example, the following was introduced into Article 42 (5): "One and the same person may not be elected the President of the Republic more than two times in a row. The present restriction shall not extend to the First President of the Republic of Kazakhstan [accentuation by the author]". During the early presidential elections held in Kazakhstan in 2011, positive and 
negative incentives for voters were given to ensure a high level of participation in the elections and to secure the re-election of Nazarbaev:

"Early voters and 18-year-olds casting their ballot for the first time were rewarded with household goods such as food blenders and electric kettles, according to the Associated Press. [...] There were several reports that students were forced to vote by threats of expulsion from university" (BBC 2011a)

Surprisingly, the governmental attempts which present Nazarbaev as the 'father of the nation' have been successful. I met students in Almaty who were totally loyal to the president. They praised him for his efforts to improve the situation of the people and unquestioningly participated in the cult of personality surrounding him. ${ }^{5}$ The next presidential elections in Kazakhstan are scheduled for 2015 (Freedom House 2013d).

Compared to Kazakhstan, neither do reports on the election of Uzbek president Karimov read any more optimistically:

"[...] a 1995 referendum extended his first term by five years. In 2000 Karimov won a second term with nearly 92 percent of the vote, but another referendum two years later extended that presidential stretch from five years to seven" (RFE/RL 2007).

In summary, the authoritarian presidents of Kazakhstan and Uzbekistan not only amend their countries' constitutions arbitrarily in order to consolidate their power but they also try to 'democratically' legitimate their power with high voter turnouts and other means. To this effect, for example, the Uzbek constitution was amended in 2011, giving more power to the parliament and political parties. President Islam Karimov introduced these changes with the aim of "further deepening democratisation and constructing a civil society" (OSW 2011). However, the public reaction to this was either scepticism or unawareness of the change (IWPR 2011). And analysts agree with this opinion: "These amendments do not limit the prerogatives of the President, who retains full authority over the country [...]" (OSW 2011). I can

5 For example, they put their hands in Nazarbaev's golden handprint in Baiterek Tower during a visit in Astana - an act seeming totally absurd to a western observer. 
conclude therefore, that despite their strong legal positions, these presidents regard a certain amount of 'legitimacy' as instrumental to staying in power.

Contrary to Kazakhstan and Uzbekistan, the first presidents of Kyrgyzstan and Tajikistan have not been able to stay in power since independence. This is the case in Kyrgyzstan although Kyrgyz President Askar Akaev extended presidential powers at the beginning of 1996 and gradually restricted the political space from the mid-1990s onwards (Anderson 1999: 23). However, in 2005, nationwide demonstrations led to the Tulip Revolution which resulted in his dismissal and brought Kurmanbek Bakiyev to power. He soon became as autocratic as his predecessor and dissolved the parliament in 2007 (Pannier 2007a). He "manipulated the parliament to accrue new powers for himself" and was re-elected in flawed elections in 2009 (ARDA: KG). Under his rule opposition politicians and independent journalists were "arrested, prosecuted, attacked and even killed" (Levy 2009). In spring 2010 nationwide protests broke out again. Bakiyev was overthrown and an interim government was proclaimed under the leadership of Roza Otunbayeva in 2010. She called for new elections and finally, Almazbek Atambayev was elected as new president in 2011. It is interesting to note that despite these violent overthrows, Kyrgyzstan is often cited as the 'democratic beacon' in the region (Kilner 2012).

"Kyrgyzstan has maintained the image as the most democratic of the Central Asian states because of the participation of genuine opposition parties in government, a strong civil society, and the lack of a ruling party" (Pannier 2007a).

These preconditions finally led to the 2011 competitive presidential elections which were "Central Asia's first voluntary transfer of power, with interim president Roza Otunbayeva standing down as scheduled" (Freedom House 2012b). Whether the political overthrows have functioned as a kind of check on political power, interfering just before a president with autocratic aspirations became too powerful, is a matter for debate. Yet Anderson might still be right to conclude that although Kyrgyzstan is not a liberal democracy, it "retains a considerable degree of social pluralism and a more open political space than any of its Central Asian neighbours" (Anderson 1999: 23). Whether Kyrgyzstan indeed deserves special status in regard of its religious policies, as well, will be discussed in 9.2. 
As for Tajikistan, in September 1991, shortly before independence, Rahmon Nabiev (himself first secretary of the Communist party of the Republic in the early 1980s but removed after a scandal) became the first elected president and was confirmed in the November 1991 election. The opposition regarded the election as rigged and a conflict between Nabievs supporters and a coalition consisting of the IRPT and democrats broke out which finally led to the civil war in spring 1992. In September $1992 \mathrm{Nabiev}$ was forced to resign by Communist hard-liners and "was replaced by Emomali Rakhmonov, a senior member of the Communist Party" (Freedom House 2013c). In December of the same year, the Kulyab-LeninabadHissar clans, led by Rahmon, defeated the Islamists and Democrats (Naumkin 2005: 202). The Islamists subsequently fled to Afghanistan, where they allied themselves with the Northern Front of Ahmad Shah Massoud. The United Tajik Opposition (UTO) now opposed the new government and the IRPT was outlawed in spring 1993. Only with the peace accord in 1997 did it regain legality: "Former IRPT fighters were incorporated in to the army and law enforcement structures and the IRPT itself was legitimized and participated in the general election of 2000" (Taarnby 2012: 16). Additionally to the integration of IRPT fighters in the regular army, the peace accord promised the IRPT $30 \%$ of the parliamentary seats. Despite this, Rahmon has steadily expanded his power at the expense of the opposition over the last few years. In November 2013, Rahmon was confirmed in office again and a 2003 constitutional referendum allows him to remain there until 2020 (Freedom House 2013c). Given that the IRPT is still legal I discuss whether this has an impact on religious freedom in Tajikistan in section 9.2.

Table 12: Political Systems and Presidents

\begin{tabular}{|l|l|l|l|l|}
\hline & Kazakhstan & Kyrgyzstan & Tajikistan & Uzbekistan \\
\hline $\begin{array}{l}\text { Political } \\
\text { System }\end{array}$ & $\begin{array}{l}\text { Presidential } \\
\text { Republic }\end{array}$ & $\begin{array}{l}\text { Parliamentary } \\
\text { Republic } \\
(\text { since } 2010)\end{array}$ & $\begin{array}{l}\text { Presidential } \\
\text { Republic }\end{array}$ & $\begin{array}{l}\text { Presidential } \\
\text { Republic }\end{array}$ \\
\hline $\begin{array}{l}\text { Sysetm of } \\
\text { Presidential } \\
\text { Election }\end{array}$ & $\begin{array}{l}\text { direct } \\
\text { election }\end{array}$ & $\begin{array}{l}\text { direct } \\
\text { election }\end{array}$ & $\begin{array}{l}\text { direct } \\
\text { election }\end{array}$ & $\begin{array}{l}\text { direct } \\
\text { election }\end{array}$ \\
\hline
\end{tabular}




\begin{tabular}{|c|c|c|c|c|}
\hline $\begin{array}{l}\text { Presidential } \\
\text { elections }^{6}\end{array}$ & $\begin{array}{l}1999 \\
2005 \\
2011 \\
\text { Next : } 2016\end{array}$ & $\begin{array}{l}2000 \\
2005 \\
2009 \\
2011\end{array}$ & $\begin{array}{l}1999 \\
2006 \\
2013\end{array}$ & $\begin{array}{l}1999 / 2000^{7} \\
2005 \\
2007 \\
\text { Next: } 2014\end{array}$ \\
\hline $\begin{array}{l}\text { President } \\
\text { In office }\end{array}$ & $\begin{array}{l}\text { Nursultan } \\
\text { Nazarbaev: } \\
\text { since } 1990\end{array}$ & $\begin{array}{l}\text { Almazbek } \\
\text { Atambayev: } \\
\text { since } 2011^{8}\end{array}$ & $\begin{array}{l}\text { Emomali } \\
\text { Rahmon: } \\
\text { since } 1992\end{array}$ & $\begin{array}{l}\text { Islam } \\
\text { Karimov: } \\
\text { since } 1990\end{array}$ \\
\hline
\end{tabular}

If we discuss the political systems of the Central Asian countries, it is easy to conclude that they do not meet western standards of democracy. However, I do not want to put political legitimacy in Central Asia on a level with free and fair elections. As we learnt in section 1.1.2, legitimacy can have diverse sources, as Weber explained. When western ovservers describe Central Asian presidents simply as autocratic rulers, they forget that in addition to democratic criterions of legitimacy they could meet other forms of legitimacy:

- Rational-legal legitimacy: the public's trust that the government will provide stability (especially in Tajikistan) and economic development (especially in Kazakhstan) is a rational consideration that can lead to the legitimacy of the government.

- Traditional legitimacy: tribalism and Soviet history can be understood as a habituation of the influence of clans in politics as well as of authoritarianism and a cult of personality that legitimizes the strong positions of the presidents in all Central Asian countries.

- Charismatic legitimacy: the belief that a 'strong man' is needed to lead the nation is essential in all Central Asian states. In this context, it is clear why, for example, the succession of the president will pose a problem in each respective country (see ICG 2013).

6 According to http://www.electionguide.org/.

71999 first round and 2000 second round.

8 Previous Kyrgyz Presidents since independence were: Askar Akayev (October 1990 - March 2005), Kurmanbek Bakiyev (July 2005 - April 2010), Roza Otunbayeva (head of interim government: April 2010 - Nov. 2011). 
As we can see in the following table, a clear preference for democracy over a powerful leader is only expressed in Tajikistan. In Kazakhstan there is more or less equal support for both views while in Kyrgyzstan the majority of people would prefer a strong leader over democracy. This might be a temporary phenomenon; the events in Osh and the considerable turmoil during recent years might explain the more conservative public opinion here. However, it is revealing that the country which has by far the best international reputation with regards to democratic values is the one with the lowest percentage of people who prefer a democracy over a powerful leader. (There are no data available for Uzbekistan.)

Figure 10: Preference for Democracy or a Powerful Leader

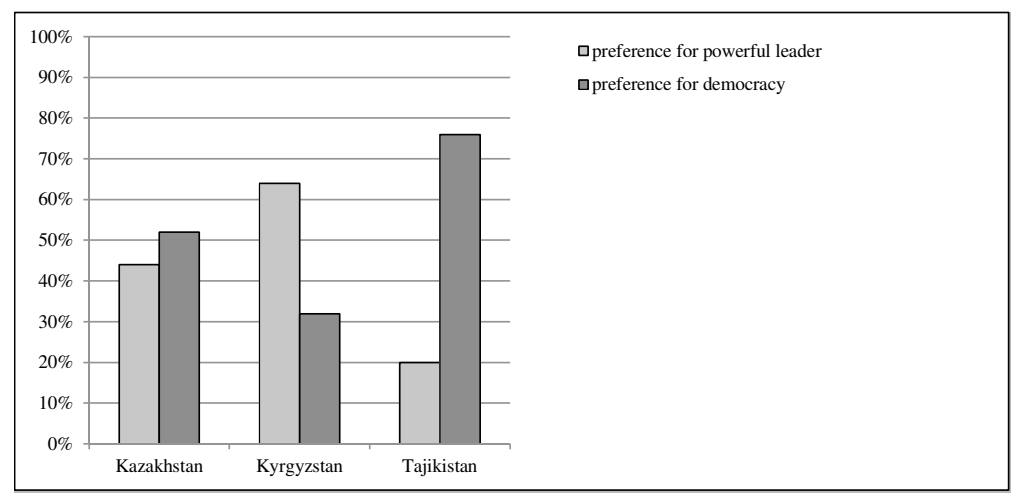

Source: PEW 2013

\subsubsection{Parliaments and Govermental Parties}

All Central Asian parliaments are bicameral, except in Kyrgyzstan, where a unicameral parliament is in power. In Kyrgyzstan, constitutional reforms took place between 1993 and 1995 which replaced the unicameral parliament with a bicameral one. However, this was reversed in 2005 to 2006, when a new constitutional reform weakened parliament's position and reintroduced the unicameral parliament (Murzakulova and Schoeberlein 2010: 158). The Uzbek parliament had been unicameral as well until 2005 when it became bicameral. As Ilgizar Sobirov, Chairman of the Senate of the Republic of Uzbekistan, explains, the parliamentary reforms laid the foundations of civil society in the country, supported the division of power 
and helped the transformation towards a market economy (Sobirov 2005). However, a quick look at the parties represented in the Uzbek parliament calls such claims into question. Indeed, whether the four parties represented in the legislative chamber are able to "observe the universal principles of rule of law" and democracy, as Sobirov declares (Sobirov 2005) is more than disputable due to their loyalty towards Karimov. The same is the case in Kazakhstan, where during the legislative election (Majilis) in January 2012, for example, "even the presidential administration has stated that both of the minor parties that entered the Majilis are pro-Nazarbayev parties." (Nichol 2013a: 4). Moreover, at the time of the presidential elections in Kazakhstan, "all of the presidential candidates proclaimed that they wanted Nazarbayev to win" (Nichol 2013a: 3).

Among the Central Asian parliaments, the number of parties varies from three to five. Yet in Kazakhstan, "the election law prohibits political parties based upon ethnicity, gender, or religious affiliation" (StateDept a: 5). Similarly, in Uzbekistan, "the government prohibits religious groups from forming political parties and social movements" (StateDept 2012d: 2). The same is true for Kyrgyzstan, although here the story is slightly different since parliamentary seats are more or less equally distributed among the parties. Moreover, Murzakulova and Schoeberlein scrutinized the Kyrgyz ideological space very thoroughly and came to the conclusion that it,

"[...] is characterised by a diversity of positions as well as actors. This is in contrast to what existed during Soviet times, when ideology was produced and disseminated by a set of central institutions under the control of the Communist Party of the Soviet Union" (Murzakulova and Schoeberlein 2010: 148).

Despite these positive findings, political parties based on religion are prohibited even in Kyrgyzstan. As the state department makes clear: "the constitution prohibits the establishment of religious political parties and the pursuit of political goals by religious groups" (StateDept 2012b: 2). Indeed, Kyrgyz political parties mainly represent the regional provenance rather than the ideological differences of their members.

As has already been mentioned, Tajikistan is the only Central Asian country with a legal political party based on Islam which is represented in the parliament. This might lead one to assume that a broader spectrum of ideas are represented than in the other Central Asian parliaments. However, in 
Tajikistan the parliamentary power also belongs invariably to the presidential party: the IRPT gained only two seats during the last parliamentary elections in 2010, a result that the party members contest.

Table 13: Structure and Composition of Parliaments

\begin{tabular}{|l|l|l|l|l|}
\hline & Kazakhstan & Kyrgyzstan & Tajikistan & Uzbekistan \\
\hline $\begin{array}{l}\text { Structure of } \\
\text { Parliament }\end{array}$ & Bicameral & Unicameral & Bicameral & $\begin{array}{l}\text { Bicameral } \\
\text { (since 2005, } \\
\text { previously } \\
\text { unicameral) }\end{array}$ \\
\hline $\begin{array}{l}\text { Name of } \\
\text { Parliament }\end{array}$ & Parlament & $\begin{array}{l}\text { Jogorku } \\
\text { Kenesh }\end{array}$ & Majlisi Oli & Oliy Majlis \\
\hline $\begin{array}{l}\text { Chamber } \\
\text { names }\end{array}$ & $\begin{array}{l}\text { Mazhilis } \\
\text { (House of } \\
\text { Representati- } \\
\text { ves) }\end{array}$ & $\begin{array}{l}\text { Senate (Sena- } \\
\text { te) }\end{array}$ & $\begin{array}{l}\text { Majlisi } \\
\text { namoyando- } \\
\text { gon (House of } \\
\text { Representati- } \\
\text { ves); } \\
\text { Majlisi milli } \\
\text { (National As- } \\
\text { sembly) }\end{array}$ & $\begin{array}{l}\text { (Legislative } \\
\text { Chamber); } \\
\text { Senat } \\
\text { (Senate) }\end{array}$ \\
\hline $\begin{array}{l}\text { Number of } \\
\text { in Parliament }\end{array}$ & 5 & $\begin{array}{l}\text { Qonunchilik } \\
5\end{array}$ & \\
\hline
\end{tabular}

Source: PARLINE (2013)

The following parties are (with the number of seats in brackets) part of the first chamber of the parliament (PARLINE 2013):

Kazakhstan:

- People's Democratic Party Nur Otan (83)

- Democratic Party of Kazakhstan Ak Zhol (8)

- Communist People's Party of Kazakhstan (7) 
Kyrgyzstan:

- Ata-Jurt (28)

- Social Democratic Party (26)

- Ar-Namys (25)

- Respublika (23)

- Ata-Merken (18)

Tajikistan

- People's Democratic Party of Tajikistan (PDPT) (55)

- Communist Party of Tajikistan (CPT) (2)

- Islamic Renaissance Party of Tajikistan (IRPT) (2)

- Agrarian Party of Tajikistan (2)

- Party of Economic Reforms of Tajikistan (2)

Uzbekistan

- Liberal Democratic Party (UzLiDeP) (20)

- People's Democratic Party of Uzbekistan (10)

- Democratic Party of Uzbekistan Milliy ti-klanish (6)

- Social Democratic Party of Uzbekistan Adolat (3)

\subsubsection{Freedom and Democracy Indices}

To get an overview of how the Central Asian regimes are governed, it is useful to have a look at freedom indices and classifications elaborated by different non-governmental organizations. With these indices it is possible to begin to compare the different ways in which these governments deal with civil liberties, political rights, political participation and elections in general. Later on, I will scrutinize each country's specific attitudes, laws and law enforcement strategies towards religious organizations and individuals.

Although the description of Kyrgyzstan as a 'Central Asian democracy' is greatly exaggerated, democracy and freedom indices distinguish this country from its neighbours. The Freedom House Index measures civil liberties and political rights on a scale from 1 to 7 with 1 meaning perfectly 
free. It assesses Kyrgyzstan as at least partly free, ${ }^{9}$ giving it 5 points for both political rights and civil liberties. By comparison, Kazakhstan also gets 5 points for civil liberties but only 6 points for political rights while Tajikistan is rated 6 in both categories. Uzbekistan receives the worst possible rating with 7 for both political rights and civil liberties, which has made it one of the nine most repressive regimes in the world for a number of years (Freedom House 2013e: 6). The situation in Kazakhstan and Tajikistan has deteriorated over the last year in the following way: (Freedom 2013: 2):

- "Kazakhstan received a downward trend arrow due to the banning of several media outlets following a violent crackdown on labor unrest" (Freedom House 2013e).

- “Tajikistan's civil liberties rating declined from 5 to 6 due to a ban on students attending international seminars and a military operation in Gorno-Badakhshan that resulted in scores of deaths, extrajudicial killings, and a media crackdown" (Freedom House 2013e).

Whereas Kazakhstan was for many years regarded as rather democratic in comparison with Uzbekistan and Tajikistan, recent events show how heavyhanded the country's government can be (I will go into further details on this when discussing the countries' religious policies). In the case of Tajikistan, some analysts suggest that among other factors, western assistance in the security sector is responsible for President Rahmon's undemocratic consolidation of power (Matveeva 2005).

The Democracy Index of The Economist Intelligence Unit (EIU) is based on the assumption that "Freedom is an essential component of democracy, but not sufficient" (EIU 2013: 26). It not only takes into consider-

9 A Free country is one where there is broad scope for open political competition, a climate of respect for civil liberties, significant independent civic life, and independent media. Partly Free countries are characterized by some restrictions on political rights and civil liberties, often in a context of corruption, weak rule of law, ethnic strife, or civil war. A Not Free country is one where basic political rights are absent, and basic civil liberties are widely and systematically denied. See: www.freedomhouse.org/sites/default/files/Map\%20of\%20Freedom $\% 202013 \% 2 \mathrm{C} \% 20$ final.pdf. 
ation the electoral process and pluralism, but also civil liberties, the efficiency of governments, political participation and the political culture of a country (EIU 2013: 26). As with the Freedom House Index, the Democracy Index also ranks Kyrgyzstan as the most democratic of the Central Asian states, describing it as a "hybrid" between autocracy and democracy whereas its Central Asian neighbours are all clearly "authoritarian". Furthermore, according to this index, Kazakhstan and Tajikistan are again almost on an equal footing while Uzbekistan is again regarded as the country with the worst situation with regards to freedom and democracy. This index also considers potential sources of instability in Central Asia, such as the "young and restless population," especially in Tajikistan and Uzbekistan (EIU 2013: 22). As for Kazakhstan and Uzbekistan, whose presidents have been able to cling to power since the early 1990s, and are now more than 70 years old, the EIU sees succession as a possible threat to stability: "No clear successors have been lined up, which increases the potential for intra-elite in-fighting, and possibly public unrest when the incumbent dies or becomes incapacitated" (EIU 2013: 22). This opinion is shared by other analysts, such as the International Crisis Group (ICG) (ICG 2013).

The Human Security Report considers procedures for political participation and freedom in the election of the chief executive. It describes Kyrgyzstan and Tajikistan as 'anocracies', which is a term describing neither fully democratic nor fully autocratic states, as well as states "in transition from one to the other" (Human Security Report, 2006: 54ff, Notes on Terminology). Conversely, Kazakhstan and Uzbekistan are described as 'autocracies'. All four countries lack "well-established procedures for political participation" and a freely elected chief executive necessary to be considered democracies. 
Table 14: Freedom and Democracy Indices

\begin{tabular}{|c|c|c|c|c|}
\hline & Kazakhstan & Kyrgyzstan & Tajikistan & Uzbekistan \\
\hline \multicolumn{5}{|c|}{ Freedom House Index $(2013)(1-7 ; 1=$ free $)$} \\
\hline $\begin{array}{l}\text { Freedom } \\
\text { Status }\end{array}$ & Not Free & Partly Free & Not Free & Not Free \\
\hline $\begin{array}{l}\text { Political } \\
\text { Rights }\end{array}$ & 6 & 5 & 6 & 7 \\
\hline $\begin{array}{l}\text { Civil Liber- } \\
\text { ties }\end{array}$ & 5 & 5 & 6 & 7 \\
\hline \multicolumn{5}{|c|}{ Regime Type } \\
\hline $\begin{array}{l}\text { Democracy } \\
\text { Index (EIU }\end{array}$ & Authoritarian & Hybrid & & Authoritarian \\
\hline $\begin{array}{l}2013)(0-10 ; \\
10= \\
\text { democratic) }\end{array}$ & 2.95 & 4.69 & 2.51 & 1.72 \\
\hline $\begin{array}{l}\text { Human } \\
\text { Security } \\
\text { Report } 2012\end{array}$ & Autocracy & Anocracy & Anocracy & Autocracy \\
\hline \multicolumn{5}{|c|}{ Freedom of the press } \\
\hline $\begin{array}{l}\text { Country } \\
\text { ranking by } \\
\text { Reporter } \\
\text { ohne Gren- } \\
\text { zen (2013) }\end{array}$ & $160 / 179$ & $106 / 179$ & $123 / 179$ & $164 / 179$ \\
\hline \multicolumn{5}{|l|}{ Corruption } \\
\hline $\begin{array}{l}\text { Assessment } \\
\text { by Freedom } \\
\text { house (2013) }\end{array}$ & $\begin{array}{l}\text { Corruption is } \\
\text { widespread }\end{array}$ & $\begin{array}{l}\text { Corruption } \\
\text { is pervasive }\end{array}$ & $\begin{array}{l}\text { Corruption is } \\
\text { pervasive }\end{array}$ & $\begin{array}{l}\text { Corruption is- } \\
\text { pervasive }\end{array}$ \\
\hline
\end{tabular}




\begin{tabular}{|l|l|l|l|l|}
\hline $\begin{array}{l}\text { Country } \\
\text { ranking by } \\
\text { Transparency } \\
\text { International } \\
(2012)\end{array}$ & $133 / 176$ & $154 / 176$ & $157 / 176$ & $170 / 176$ \\
\hline
\end{tabular}

All four countries are extremely corrupt as Transparency International's country rankings show and how Freedom House explains: In Kazakhstan, corruption is "widespread" and in the other three countries "pervasive" (Transparency International 2012).

\subsubsection{Nations and Ethnicity, Clans and Tribes in Politics}

When the former Soviet republics suddenly became independent 'nation states', they had to forge some kind of national ideology (see Murzakulova and Schoeberlein 2010; also Cummings 2010, Pelkmans 2006). Due to the fact that the break-up of the Soviet Union also meant the falling away of the previously very prominent communist ideology, the new states had to find another ideological reference system. The ideological nation-building subsequently combined the Soviet understanding of the nation with pre-Soviet traditions. On the one hand they relied on ancient traditions and social structures and on the other hand on religious history to ideologically hold their countries together. Even during Soviet times, political institutions were influenced by pre-Soviet traditions and customs. After independence this influence became even more apparent due to the nation-building process.

When the Central Asian territories became Soviet Republics, they suddenly became constrained to a fixed territory where beforehand fluid boundaries existed (Petric 2011). The name-giving titular-nations at once conceived of their history as

"[...] a series of distinct developments independent of and without respect to developments in other ethno-national groups even though these populations lived for centuries in a shared social space without thinking of themselves as living in separate worlds" (Petric 2011: 167). 
One example of this is the aforementioned depiction of Timur as an Uzbek ancestor although he was actually a Turkish speaking Mongol. The Central Asian governments appeal "to the legacy of ancient and medieval Central Eurasian empires and khanates, the succession to which the present states pretend to be [...]" (Morozova 2004: 16). The contemporary Uzbek state is built on the territory of the Emirate of Bukhara and the Khorezm and Khiva Khanates. Thus, what is now understood as a nation often has no common history. Similarly, the Kazakh people, "a mix of Turkic and Mongol nomadic tribes who migrated into the region in the 13th century, were rarely united as a single nation" (ARDA: KZ). Although the artificiality of these nations is often stressed in the literature, I will not judge here whether the Central Asian nations are more or less 'authentic' than other nations. What concerns me more is the fact that the territorial fixation of the Central Asian regions took place when they became Soviet Republics.

In addition to historical and territorial factors, the ethno-national boundaries established between the new countries were to a great degree the product of the national politics under Stalin (Petric 2011). Since then, because of differences in the ethnic composition of the republics, different policies have been developed concerning the titular nation. Uzbeks, for example, "usually occupy contiguous areas and share a common pre-Soviet history and regional identity" (Finke 2011: 68). Finke argues that in Uzbekistan "the titular group" therefore "seems sufficient to ensure an unambiguous sense of national identity" (Finke 2011: 68). In Kazakhstan, by contrast, the titular nation did not even constitute $50 \%$ of the overall population when the Republic became independent. As a consequence, the government implemented a program to bring ethnic Kazakhs living in neighbouring countries 'back' to Kazakhstan. Incentives were given to reward those who complied with the state social engineering plan. This resulted in some Kazakh villages in Uzbekistan being left totally empty when their inhabitants all moved to Kazakhstan.

It is a commonality of those states with a smaller percentage of the titular nation to "appeal to the rich multi-ethnic heritage of the Soviet Union" (Finke 2011: 68). Despite its attempts to increase numbers of those with eponymous ethnicity, this is especially true for Kazakhstan:

"In contrast to its counterparts to the south, the Kazakhstani leadership did not try to battle Sovietism, but absorbed it. [...] the leadership used exactly this [ethnic] diver- 
sity as a basis for state identity. In this new myth, the regime acts as a guarantor of the preservation of multi-ethnic diversity, and actively promotes the idea of 'Kazakhstan - our common home' in the public sphere" (Matveeva 2010: 22).

Language-politics can exemplify this: in Kazkahstan and Kyrgyzstan Russian still enjoys the status of an official language. In Tajikistan and Uzbekistan, where around $90 \%$ of the population ethnically belong to the titular nation, only the language of the titular nation has official status - in Uzbekistan the kyrillic alphabet was even exchanged for the latin alphabet in 1995.

When I speak of Soviet institutions and traditional customs that have an impact on the contemporary nation-states, it is important to note that some pre-Soviet features which are evident today were also relevant during Soviet times. One of these features is the clan or tribal structure of Central Asian societies (I use here tribe and clan as umbrella terms, although sometimes traditional structures are rather structures of regional origin, as I show). Although this was not intended by Soviet politics, we know today that clan structures survived the Soviet era, as Ostrowski makes clear: "It has been argued that the Soviet project did not eradicate these traditional social structures, but rather forced them to adapt to the formal institutions" (Ostrowski 2010: 18). ${ }^{10}$ In fact, far from eradicating clan structures, the dissolution of the Soviet Union has dramatically increased their role in society, politics and among the elite in all Central Asian states (Matveeva 1999: 26).

Though it is clear that clan structures have survived the Soviet era, Central Asian governments' policies toward the reintegration of these structures into politics differs and is sometimes contradictory. For example, despite the fact that Nazarbaev would likely be able to strengthen his power by relying on his own zhuz (tribe), which is the Elder zhuz (Ostrowski 2010: 17), the advisor to the President Yermukhamet Yertysbayev explains that Kazakhs should not think anymore in terms of "the categories of the MongolTatar invasion era", and realize instead that they live in the twenty first century (TengriNews 2012). Although the Kazakh government does not officially appreciate the impact of tribal origins and group affinities in politics,

10 For example, the Kholkhozes often functioned along tribal lines (Ostrowski 2010: 18). 
Nazarbaev's strength "lies in his ability to ensure that all three zhuz receive equal representation in the top levels of government" (Ostrowski 2010: 17). He takes on the role of an arbiter in case of inter zhuz-struggles and thereby helps consolidate his power (Ostrowski 2010: 17). But tribal affiliations are not just important in the realm of politics, as Morozova makes clear, "In Kazakhstan, strategic industries and the most profitable sectors of the economy belong to, or are controlled by members of the presidential family and their relatives" (Morozova 2004: 16). Clan allegiances therefore also impact the economy.

In Kyrgyzstan political parties emerged along tribal lines and the governmental overthrows had a lot to do with clan politics. Indeed, tribal affiliations are the unique source of Kyrgyz political loyalties, and are crucial for the distribution of key political posts: "Having an important role in distributing political power, tribal affiliations [...] continue their dominancy over the political leaders in political processes of state-building" (TengriNews 2012). Because of the immense importance of regional origins and tribal heritage, since 2012 Kyrgyz officials have been obliged to reveal their tribal affinities (TengriNews 2012).

In Tajikistan the struggle between the clans led to the civil war (Morozova 2004: 16). Clans from Leninabad and Kulyab were both concerned that their positions would be contested by the success of the opposition Pamir and Garm regional clans. Additionally to this, a religious aspect was evident in the civil war, but the importance of the regional and clan origins is indisputable.

In regard of its understanding of ethnicity, Uzbekistan distinguishes itself from its neighbours, as it is "not so much based on primordial concepts of genealogies and blood relationships but linked with local and regional attachment to the nation state as the largest extension of the same principle" (Finke 2011: 71). In the very beginning, Karimov was a weak political figure due to his lack of relationships to the strong Tashkent and Ferghana clans. Instead, he was regarded as only half Uzbek and half Tajik; having a Slav wife also did little for his reputation (Naumkin 2005: 69). However, it seems that Karimov found a way to deal with what Petric describes as the factional patterns that pervade Uzbek society (Petric 2011: 171). When filling political positions, Karimov attaches importance to regional origins (Morozova 2004: 16; Petric 2011: 170). However, even in the imposition of political posts, some Soviet heritage can be found: 
"During the Soviet era the running of a kolkhoze (a faction, or even a ministry) was entrusted to an Uzbek while the second-in-command was a 'European' (for example, Russian, Ukrainian) in charge of controlling the local official. Nowadays, this policy remains but the second-in-command is no longer a European: he is now a reliable member of the President's faction (Sambuh)" (Petric 2011: 171).

This strategy has no doubt played an important role in consolidating Karimov's power.

In addition to the regional origins, solidarity networks are, according to Petric, key entities in Uzbek politics, functioning not only on the local, but also on the national level:

"The nominations for positions and the dismissal resemble the patterns of gift and counter-gift exchange since these actions are based on personal affiliations. In this society, a position within the administration is similar to a gift exchange because it implies obligations for the beneficiary" (Petric 2011: 172).

The government makes cautious use not only of regional origins and traditions to ensure its control of the country, but also mahalla (community networks), which are used to promote its policies: "Open and free private discussion is limited by the mahalla committees, traditional neighborhood organizations that the government has turned into an official system for public surveillance and control" (Freedom House 2013d). This has a reinforcing effect on patriarchal and patronal structures in the Uzbek society in general (Khazanov 2005).

Other traditional norms, which have no direct political influence, are playing a growing role in the society, as Kehl-Bodrogi points out with reference to Uzbekistan: "religiously tinged norms and values, particularity with regard to gender relations and the family, are widely propagated in the mass media and supported by popular literature" (Kehl-Bodrogi 2006: 238). Similarly, in Kazakhstan the newly introduced post-indepedence nationalism has brought about more patriarchal traditions than during Soviet times (Wilson Center 2011). In southern Kazakhstan as well as in Kyrgyzstan, for example, bride kidnapping is once again becoming very common, after the practice had previously all but become obsolete during the communist era. As a result, Kyrgyzstan has introduced stricter punishments for bride kidnappers and in early 2014 such a regulation was also discussed in the Ka- 
zakh parliament (EurasiaNet 2014). Indeed, the parliamentarian debate helps illustrate the conflicting views on the issue: "One outraged lawmaker urged the death penalty for the crime; another vehemently defended the abduction and forced marriage of young women as a national tradition" (EurasiaNet 2014).

As this example indicates, the politics of the Central Asian states differ in how they deal with such 'apolitical' traditions. Tajikistan, for example, has introduced a Law on Observing National Traditions and Rituals which,

"Regulates private celebration and funeral services, including weddings, funerals, and Mavludi Payghambar (the Prophet Muhammad's birthday). The law limits the number of guests, eliminates engagement parties, and controls ceremonial gift presentations and other rituals. The religion law reiterates these principles, mandating that 'mass worship, religious traditions, and ceremonies should be carried out according to the procedure of holding meetings, rallies, demonstrations, and peaceful processions prescribed by law of the Republic of Tajikistan' " (StateDept 2012c: 4).

In Tajikistan, then, the law dictates how tradition and religion should be observed. Here we see how much Central Asian states interfere with folk Islam although they argue that they accept 'traditional' Islam and only oppose 'foreign Islam' in order to fight terrorism. I will go into further details of this issue in the next chapters. 



\section{Comparison of the Contemporary Role of Religion in Politics}

I am interested in the repression of religious groups in Central Asia, and the theoretical framework that the Central Asian states have adopted towards religion is important in this regard. However, the practical measures taken by state bodies to suppress religious groups and individuals are at the centre of my attention. First, I discuss whether or not the countries' constitutions guarantee religious freedom and then I move to the religious laws these countries have adopted in order to minimize extremist influences on Islam. After scrutinizing this theoretical framework I will turn to the implementation of these religious laws. In the second section, I consider which state bodies are involved in countering terrorism and extremism. My interest then turns to considerations of whether detentions are conducted in accordance with the law or take place arbitrarily; whether trials are fair or extorted evidence is used and, finally, whether conditions of imprisonment meet human rights standards.

First I will answer the following questions which focus on the theoretical background:

- Constitutions: do they tend to guarantee freedom of belief? Are they secular?

- Religious laws: do they guarantee freedom of belief?

Then I will turn to the following questions concerning the practical implementation of legal regulations: 
- Pre-trial: do arbitrary arrests take place? Do extrajudicial killings take place?

- Trial: are trials fair? Is evidence extorted?

- Prison regime: are basic human rights respected during arrest? Are political and religious prison inmates discriminated against? What are the conditions of imprisonment like?

Resolving these questions requires me to make a comparison of the different countries according to when and how they respect or disregard human rights in the fight against religious extremism. In both sections I will also present the state institutions which are involved with the main issues of my study: religion and security. Finally, in chapter 9 I will elaborate a typology of the state regulation of religion.

\subsection{Freedom of ReLIGION AND THE Concept Of RECOGNITION}

What does Freedom of Religion mean exactly? The Universal Declaration of Human Rights considers the freedom of religion or belief under Article 18:

"Everyone has the right to freedom of thought, conscience and religion; this right includes freedom to change his religion or belief, and freedom, either alone or in community with others and in public or private, to manifest his religion or belief in teaching, practice, worship and observance" (The Universal Declaration of Human Rights, Art. 18).

As we see, in order to fully enjoy the freedom of religion or belief, individuals have the right to practice their religion either alone or with others. Furthermore, it is important to note that:

"Respect for freedom of religion or belief as a human right does not depend on administrative registration procedures, as it has the status of a human right, prior to and independent of any acts of State approval" (Bielefeldt 2011: 1) 
However, this freedom of religion is not always stringently adhered to by each state's processes of recognition for religious groups. Heiner Bielefeldt, Special Rapporteur on freedom of religion or belief for the United Nations, clears up "misunderstandings concerning the meaning of 'recognition' and the role of the State in this respect" in a special report (Bielefeldt 2011: 1). This report will help us to gain a more in-depth understanding of the registration processes of religious groups in the Central Asian states. Bielefeldt distinguishes the following definitions of recognition of religion by a state:

"a) Recognition in the sense of the due respect of the status of all human beings as right holders by virtue of their inherited dignity, b) Recognition in terms of States providing for the possibility of obtaining the status of legal personality, which religious or belief groups may need for the exercise of important communitarian aspects of their freedom of religion or belief c) Recognition in the sense of States according a specific privileged status position to some religious or belief communities" (Bielefeldt 2011: 1; author's emphases).

Bielefeldt explains that the confounding of these different meanings can "negatively affect the implementation of freedom of religion or belief, or even undermine its status as a universal human right" (Bielefeldt 2011: 1). I will here refer to these categorizations in order to understand and classify the attitudes of the Central Asian states towards religion. As we will see below, all four states recognize the human right of religious freedom in their constitutions as a). However, registration processes for religious organization in order to obtain legal status fall under b), whereas the declaration of a 'special status' to the Hanafi madhab by the Tajik government and the recognition of 'traditional religions' in Kazakhstan fall under c).

\subsection{Secularity in the Constitution}

\subsubsection{The Human Right to Freedom of Religion}

The preamble of the Swiss constitution reads as follows: "In the name of God, the almighty!" which is not explicitly secular. By contrast, the preambles of the Central Asian states do not include any sort of religiosity with 
the slight exception of Kyrgyzstan which aspires to: "root the [...] spiritual development of the people; [...]".

In fact, the constitutions of Kazakhstan, Kyrgyzstan and Tajikistan prominently declare secularity in their constitutions in the very first article. They read as follows:

- Kazakh Constitution, Article 1, para.1: "The Republic of Kazakhstan proclaims itself a democratic, secular, legal and social state whose highest values are an individual, his life, rights and freedoms."

- Kyrgyz Constitution, Article 1, para.1: "The Kyrgyz Republic (Kyrgyzstan) is a sovereign, democratic, secular, unitary and social state governed by the rule of law."

- Tajik Constitution, Article 1: "The Republic of Tajikistan is a sovereign, democratic, law-governed, secular, and unitary state. [...]"

The first article of the Uzbek Constitution states only that "Uzbekistan is a sovereign democratic republic," but does declare the following with regards to the separation of state and religion in Article 61: "Religious organizations and associations shall be separated from the state and equal before law. The state shall not interfere with the activity of religious associations." This is similar to the Soviet constitutions.

Surprisingly in light of Soviet religious policies, the 1936 Soviet constitution mentions the freedom of conscience (and the right to atheistic propaganda) only omitting this article in the 1977 constitution. ${ }^{1}$ Today, except in the Tajik constitution, where the freedom of conscience is not mentioned, it is explicitly confirmed in all Central Asian constitutions:

- Kazakh Constitution, Article 22, para. 1: "Everyone shall have the right to freedom of conscience."

- Kyrgyz Constitution, Article 32, para. 1: "1. Everyone shall be guaranteed freedom of conscience and belief."

11936 Soviet constitution, Article 52 "Citizens of the USSR are guaranteed freedom of conscience, that is, the right to profess or not to profess any religion, and to conduct religious worship or atheistic propaganda. Incitement of hostility or hatred on religious grounds is prohibited." 
- Uzbek Constitution Article 31: "Freedom of conscience is guaranteed to all. Everyone shall have the right to profess or not to profess any religion. Any compulsory imposition of religion shall be impermissible."

However, there are some constraints that can be imposed upon these rights. For example, article 22 of the Kazakh constitution continues in para. 2: "The right to freedom of conscience must not specify or limit universal human and civil rights and responsibilities before the state." Furthermore, as the following analysis by the Berkley Center shows, the rights declared in the Uzbek constitution are only guaranteed in so far as they are not at odds with other more important 'interests of the state', which are defined in Article 20 of the constitution:

“Citing Article 20, Karimov has sanctioned his government's crackdown on Muslims by declaring that their 'Wahhabi' ideology conflicts with state security. By monopolizing constitutional interpretation, the Uzbek president is effectively ensuring that state policy cannot be limited through constitutional precepts" (Berkley Center e).

Indeed the maintenance of presidential hegemony takes priority over human rights concerns in all Central Asian states. The US State Department's International Religious Freedom Reports of these countries more or less come to the same conclusion regarding freedom of religion: "The constitution provides for religious freedom; however, other laws and policies restrict religious freedom and, in practice, the government generally enforced these restrictions" (StateDept 2012a: 1).

\subsubsection{Religion as a Means of Ideological Nation-Building}

Whereas the above mentioned freedom of religion referred to the human right of the individual, now I turn to what Bielefeldt classifies "a specific privileged status position to some religious or belief communities" given by the state (Bielefeldt 2011: 1).

Besides the explicit articles in Central Asian constitutions on secularism, these constitutions also declare that no state ideology or state religion can be established. For example, the Kyrgyz constitution, "[...] prohibits the establishment of any religion as a state or mandatory religion. Further- 
more, the government prohibits religious groups and clergy from interfering in the activities of government institutions" (StateDept 2012b: 2). However, such stipulations do not hinder governments from according a special status to some religious organizations. For example, Article 8 of the Tajik constitution explains that:

"In Tajikistan public life is to develop on the basis of political and ideological diversity. No ideology, including religious ideology, is granted the status of state ideology. [...]"

Despite this, it recognizes the special status of the Hanafi school (StateDept 2012c: 2). This has led to some confusion among authors, who have wrongly stated that the Hanafi school is the official state religion of Tajikistan (see as an example Yuldoshev 2009a). Special status is also given to the following religious groups in Kazakhstan, which are considered 'traditional' and therefore privileged: Islam (represented by SAMK), Russian Orthodoxy, Roman Catholicism, Lutheranism, Judaism (StateDept 2012a: 10). With "a recently adopted law regulating religious relations $[\ldots]$ the state acknowledges the place and the role of Hanafiyah in the spiritual life of our people", says Nazarbaev (Nazarbaev in TengriNews 2013).

The Muslim Board of Uzbekistan (MBU) - an institution presented in more detail in the next section - runs the shrine complex of Ulli Pir in Khorezm; the museum and a guesthouse near the site are administered by the state-run Centre for Morals and Enlightenment (Ma'naviyat va Ma'rifat Markazi) (Kehl-Bodrogi 2006: 243). In Kyrgyzstan, holy places such as Manas Ordo and the Throne of Suleiman are called national, historical or cultural sites by state authorities (Toktogulova 2007: 509). By what means did secular regimes come to maintain such holy places? One explanation might be ideological nation-building. Another could be the state's desire to have more control over the religious sites.

I already introduced the need of the newly independent started for a new national ideology above: they started to fuse together historical figures, nationalistic and religious ideologies in order to build an ideological base for their nation states. The results of their efforts, as well as the measures taken to implement their respective ideologies, vary distinctly from state to state. The former Turkmen leader Saparmurat Niyazov was an exceptional case in this regard. He authored the book Rukhnama, which he raised to the 
level of the Quran, and decreed that it had to be read and recited by the Turkmen citizens at many different occasions (Pelkmans 2006). The other Central Asian governments did not go to such lengths to foster the cult of personality but rather capitalized on the cultural symbolism of Islam. As Schoeberlein explains, they "[...] promote historical figures and cultural practices associated with Islam as part of their revival of national culture more broadly" (Schoeberlein 2009: 105). In particular, states' attitudes towards popular religious traditions have changed since independence. KehlBodrogi shows this citing Uzbekistan as an example:

"In a clear break with the official interpretation of Islam in the Soviet Union, the state now acknowledges popular religious traditions as legitimate expressions of faith and part of the 'golden heritage' (altin meros) of the Uzbek people" (KehlBodrogi 2006: 238).

Indeed, the shift from an interpretation of Islam which relied mainly on scholarly Sunni Islam also occurred in the other newly independent Central Asian states. Contrary to the policy of the Soviet Union, the newly independent Central Asian states "preferred to recruit among relatively uneducated parallel ex-mullahs rather than among the élite who had been educated in the Arab countries during the Soviet era" (Roy 2000: 158). This was partly due to the fact that after independence, the number of worshippers increased too rapidly for educated imams to meet the new demand (Salmorbekova and Yemelianova 2010: 227). This shortage of educated imams and the acceptance of former parallel mullahs by the Central Asian governments as well as the large scale reopening of village or mahalla mosques (which were closed during the Soviet Union) might also have served to strengthen traditional Islam.

Whereas differences between contemporary state Islam and official Soviet Islam can be observed, there are also similarities regarding the understanding of religion and the role of Islam in state politics. The Soviet understanding of culture and identity as well as their 'nationalization of religion' played an important role in the formation of national identities of the contemporary states (Khalid 2007: 3; Pelkmans 2006). And just as the Soviets understood religion to be more a symbol of national identity than a matter of spirituality so too do the political leaders of the Central Asian states. They "maintain the Soviet modernist antipathy for religion and would like 
to see Islam play only a symbolic role and no political role in their countries" (Schoeberlein 2009: 104). For this end they use Islamic symbols on national flags or banknotes, celebrate Muslim holidays and ceremonies and often use religious expressions (Roy 2000: 159). Indeed, political leaders make conscious use of Islamic symbols in order to strengthen their legitimacy and their rule (Roy 2000: 159; Karagiannis 2010: 15; Yemelianova 2010: 27). Furthermore, all Central Asian countries currently belong to the Organization of the Islamic Conference.

The Central Asian governments today refer to 'traditional Islam' as being officially accepted and mention the Hanafi School and Sufi Islam in this context. In fact, Sufi Islam, persecuted during the Soviet Union, was rehabilitated by the newly independent states, as Kehl-Bodrogi points out:

"The [Uzbek] government is equally supportive of the literary reconstruction of the Sufi tradition [...], and has made the celebration of the lives of medieval Sufi awliya (avliyo) a centrepiece of its nation-building agenda." (Kehl-Bodrogi 2006: 238).

The main purpose of this rehabilitation should by now be clear; as Fathi asserts, national leaders have been "building a national Islam to reinforce their policies of national consolidation. Since declaring independence, they have encouraged re-Islamization "from the top'" (Fathi 2011: 174). For example, "Uzbekistan laid on a major commemoration of Bahauddin Naqshband in Bukhara, and used the fact that both the Ysawiyah and the Naqshbandiyah originated in Central Asia" (Roy 2000: 159), while in Kazakhstan, Ahmet Yasawi, the founder of the Sufi Yasawiy tariqa, was declared a "figure of national importance" (Khalid 2007: 132).

As Kariagiannis points out, the state celebration of Ahmet Yasawi in Kazakhstan shows how attitudes towards Sufism have changed since traditional Islam is now regarded as a useful means of opposing radical Islam: "[...] a few regional governments have attempted to integrate elements of Sufi Islam into their state ideology and have promoted Sufism as an alternative to political Islam" (Karagiannis 2010: 15). However, equating 'traditional Islam' with Sufi practice suggests a very superficial understanding of religiosity. Precisely in Kazakhstan, for example, Sufism is not officially recognized (Berkley Center a) despite its veneration of Sufi leaders. In fact, just recently a prominent Sufi - incidentally a follower of Ahmed Yasawi was sentenced to fourteen years in prison (RFE/RL 2013). 
As for what 'traditional Islam' means exactly: this is open to discussion. While common people seem to understand this term to mean merely Islamo-national life-cycle rituals, imams refer to the typical Central Asian interpretation of the Quran (Salmorbekova and Yemelianova 2010: 230f). In any case, the main political function of the introduction of this term seems to be that today foreign influence on Islam is unwanted: official 'traditional' Islam has been used to contrast 'foreign' extremism. In the local 'War on Terror' the authorities' main argument is that foreign influences contradict traditional Islam, and thereby disunite society. ${ }^{2}$ In this sense, traditional Islam is put forward as the main ideological solution to foreign-influenced Islamist movements (Roy 2000: 159). In addition, contemporary regimes have used their definition of Sufism as 'traditional' Islam for their own ends, namely to provide a counterweight to the 'radical' Islam which leads to terrorism. For example, there is no doubt that the Uzbek state's "benevolence towards popular religiosity is guided not least by the notion that it is less of a potential threat than scripturalist variants of the faith" (KehlBodrogi 2006: 238). Schoeberlein advances the same view and also implicitly cautions against dangerous 'foreign' branches of Islam:

To summarize, all of the four states try to control religion as tightly as possible and "take for granted the right to regulate religious life through formal bureaucratic channels" and "resolutely oppose the wrong kind of Islam" (Khalid 2007: 132). On the one hand the contemporary Central Asian regimes take advantage of and even fear the revival of Islam as an opposition force but on the other, they support it for their own advantage.

\subsection{Content of Religious Laws}

At first sight it appears strange that countries with predominantly Muslim populations enact laws forbidding the wearing of headscarves at schools an issue broadly discussed in Europe. However, as we will see in this section, all four Central Asian states consider schoolgirls' headdresses an issue. Religious laws not only determine which specific religious groups are allowed to practice in the country, where they might worship, and even

2 See "Osh officials hear concerns about uncertified imams": www.centralasia online.com/en_GB/articles/caii/newsbriefs/2012/05/10/newsbrief-16 (15.5.12). 
what content their literature and materials can comprise, but also limit religious instruction.

The toughening of policies towards Islam started in the mid-1990s. Khalid attributes this to external factors - the civil war in Tajikistan and the gaining of power of the Taliban in Afghanistan (Khalid 2007: 132). General statements on the religious laws, which have become increasingly restrictive over the last few years, have become widespread in the literature on Central Asia. Indeed, since no specific comparison of the diverse religious issues has been conducted yet, I will attempt to do so here. However, this comparison is only cursory in part because I do not have a juristic background and the laws and regulations are changing on a regular basis. At any rate, I will be able to identify and compare the most important means used to control religious practice in the Central Asian states and get an idea of the degree of formally or legally sanctioned restrictions on religion. In addition to the countries' laws on religion, the fatwas of the Council of Ulama or the Muftiate have a binding character (more on these institutions in the next section).

The current law on 'Religious Activity and Religious Associations' was approved in Kazakhstan on October 11, 2011. Nazarbaev explained that the law was necessary in order to protect the country from religious extremism and that "interfaith accord is one of the fundamentals of the unity of the [Kazakh] nation" (Nazarbaev in TengriNews 2011b). In addition to the religious law, the "State Program to Counter Religious Extremism and Terrorism" applies for the period 2013 to 2017. It introduces preventive means, such as a compulsory school subject which provides instruction on "traditional religions" (Corley 2013).

Kyrgyzstan adopted the law "On Freedom of Conscience and Religious Organizations" in 2009. Amendments were made to it in 2012, integrating an article on religious materials. Other amendments discussed in the unicameral parliament concerned the sending of students to foreign religious colleges, stipulating a minimum of 200 citizens for officially sanctioned religious communities and the licencing of foreigners who conduct religious activities (Corley 2012).

The Tajik "Law on freedom of conscience and religious associations" came into force on 26 March 2009. It restricts worship to four locations: mosques, cemeteries, homes, and holy shrines. In addition, it distinguishes itself from the religious laws of the other countries with regards to the tight 
control of the religious content of sermons: "[...] government censors now monitor Friday sermons, stepping in when muftis stray from the government line" (Schwirtz 2011). Amendments to the Code of Administrative Offences show how the Tajik government ascribes extremism to 'foreign' Islam. These amendments define the punishment for "those violating the religion law's tight restrictions on sending Tajik citizens abroad for religious education, preaching and teaching religious doctrines, and establishing ties with religious groups abroad" (StateDept 2012c: 3). Here too we can observe the aforementioned policy of traditionalization of religion. In addition, in 2004 the Tajik Council of Ulema published a fatwa against women attending mosques, arguing that they should pray at home (StateDept 2011: $1)$.

Uzbekistan was the first Central Asian state to declare Islamic extremism a major threat to national security when it introduced a new law on religion in 1998. With the law "On Freedom of Conscience and Religious Organizations" the "[...] state policy towards Islam has in fact become increasingly repressive" (Kehl-Bodrogi 2006: 238). Also in Uzbekistan the state "exercises strict control over Islamic worship, including the content of sermons" (Freedom House 2013d). Already in the 1990s and especially after he Andijan events in 2005, Uzbekistan was regarded as the most repressive regime in Central Asia (apart from Turkmenistan) by western observers and human rights organizations. However, Uzbekistan was only the forerunner and the other Central Asian states soon followed up as I can show in the next sections.

\subsubsection{Religious Clothing, Hijab and Beard}

In their policies towards Islam, the Central Asian states have relied to a great extent on Soviet practice (see for example McGlinchey 2006: 128). If we bear in mind the Soviets' campaign against the hijab, the contemporary banning of the hijab (Muslim headscarf) is easier to understand.

Also in the context of this issue, the 'traditionalization of religion' and the special status for 'traditional' Islam can be observed. In Kazakhstan and in Tajikistan the national headdress for women is permitted (and even promoted) by each respective government, but 'foreign' fashions of wearing the hijab are partially prohibited. Absattar Derbissali, Kazakh Supreme Mufti until February 2013 explained this in the following way: 
"Concerning our country's girls, women: Kazakhs have beautiful national clothes, but it is not hijab. We should not wear Afghanistan's national clothes. Our people, our women have to dress according to traditions of our ethnicity" (TengriNews 2011a).

We see in this quote again how the Central Asian governments fear foreign influences on Islam and contrast them with their own traditions. The wearing of hijabs is not forbidden in Kazakhstan, but the Head of the Agency of Religious Affairs (ARA) explains that it is not necessary to wear a hijab to show one's religiosity (TengriNews 2011b). Indeed, it was reported that the education department of Aktobe oblast keeps a list of school students who wear a hijab. Although the Department explains that this is just "done to know their exact number" (TengriNews 2011c), in the context of the political persecution of devout individuals, this might raise concerns.

In Kyrgyzstan the situation seems similarly unclear, which shows that this is a delicate topic. On the one hand, Freedom House reports that two months after the 2009 religious law came into effect, the wearing of headscarves was prohibited in Kyrgyz schools (Freedom House KG 2012). On the other hand, the State Department Report on Religious Freedom of the same year says that so far the Kyrgyz government has banned neither hijabs nor religious clothing in schools (StateDept 2012b: 4). Officially at least, there is no ban:

"Ministry [of Education and Science] officials have adamantly denied a ban, saying the only reason headscarves might not be allowed by some teachers or administrators is because they are not a part of the official public-school uniform for female students" (Schenkkan 2011b).

Nevertheless, some parents have complained about "harassment by teachers and school administrators toward hijab-wearing students" (Schenkkan 2011b). What makes the situation in Kyrgyzstan unique, and distinguishes it from the one in Kazakhstan, is how the Muftiate reacted to this dispute. The Muftiate supported Muslim groups who argued that a ban would violate the constitutional guarantee of religious freedom and "posted a hotline for complaints on its website" (Schenkkan 2011b). By contrast, in Tajikistan the Tajik Ministry of Education (MOE) clearly banned the hijab from 
schools and universities in 2005, arguing that this was necessary to safeguard the secular education system (Freedom House 2013c, StateDept 2012: 1). Here, "the Council of Ulemo members have not disputed the MOE dress code banning the hijab in schools and have promoted official government policies, saying that the national head covering may substitute for the hijab" (StateDept 2011: 5). As in Kazakhstan, here too a distinction is made between the hijab and the traditionally tied headscarf: "Women wearing a traditional local head covering, a scarf which covers the hair but not the neck, were allowed to study in schools and universities" (StateDept 2011: 1). Besides the issue of hijab at school, the Tajik MOE prohibits teachers under the age of 50 from wearing beards (StateDept 2012c: 3). More generally, "there were reports that men were not able to obtain a passport if photographed with a beard, and women were not permitted to be photographed while wearing a hijab, unless traveling for the hajj" (StateDept 2011). In Uzbekistan, as usual, the situation is more extreme with religious clothing banned not only from schools but even from public places in general with the exception of those serving in religious organizations (StateDept 2012d: 4).

Another issue newly raised in Kazakhstan is the following: It is reported that at Al-Farabi Univeristy in Almaty the names of students who read namaz are collected and that they are interrogated - preventively, in order to be able to control who potentially could leave for Syria to execute jihad there. $^{3}$

\subsubsection{Religious Instruction}

As I have shown in section 7.1, the right to religious instruction is included in the freedom of religion in Article 18 of the Universal Declaration of Human Rights. I use here the terms 'religious instruction' and 'religious education' interchangeably, although sometimes the first term tends to be used for the teaching of one particular religion and the second for teaching about religions in general. In the Central Asian context, several different school levels are discussed under the umbrella term 'Muslim religious education':

3 See http://rus.azattyk.org/content/spisok-chitayuschikh-namaz-studentov/25173 602.html (8.2.2014). 
- maktabs provide primary religious education for children at mosques; ${ }^{4}$

- madrasas operate at the secondary school level and qualify students for university by teaching them diverse subjects in addition to giving them a Muslim education;

- Islamic Universities which teach Muslim theology;

- private homes where children and adults can receive Quran lessons, where Surahs are recited, Arab scripture and grammar learnt and individual guidance about religion takes place between teacher and student.

Bearing the human right to religious instruction in mind, the question of where children and students today receive religious instruction today presents itself. More specifically:

- Are private religious classes allowed and under what conditions?

- What is the status of religion in public schools?

- What are the officially recognized religious institutes?

- Are students allowed to travel abroad to follow a course of religious instruction at the higher education level?

I will start with the similarities among the Central Asian states before going on to discuss exceptional cases. I will then provide more detailed information regarding the specific countries.

Religious instruction currently tends to be restricted to registered religious communities (see section 7.5.1 for registration processes). For higher Islamic education, the permission of the Ministry of Education (MOE) is needed, which means that tertiary level religious instruction is restricted to government-approved institutions.

Although private religious tutoring for children is prohibited in all four countries, it has a long tradition in Central Asia (Stephan 2010: 471):

"They provide an elementary Islamic education, with the aim of turning young boys and girls into genuine believers and good Muslims [...]. As a result of their connection to the local mosque, their proximity to the households and the local background of the teaching staff, the maktab were embedded in urban and rural neighbourhoods,

4 The use of the name 'maktab' is unclear, as it seems that it is sometimes also used to refer to secular primary education. 
and guaranteed the reproduction of local knowledge and local religious authority" (Stephan 2010: 471).

Today, it is common for children to be sent to private religious classes by parents who find themselves in difficult economic and social situations in order to help raise their children as ethical individuals (interview with Kyrgyz expert in Islamic studies; Stephan 2010). This is also true (perhaps even more so) for the many grandparents who look after the grandchildren of parents working abroad as migrant labourers (interview with Kyrgyz expert in Islamic studies).

During Soviet times, besides strengthening the character of children, learning in private homes had an additional purpose: it was one of the primary means by which popular Islam was able to survive. Especially in areas where few or no official mosques existed, an informal system of spiritual education came into being (Naumkin 2005: 21) by means of clandestine prayer houses, which were set up in the homes of Sufi shaykhs. These also became meeting places for general believers and/or for Sufi adepts (Bennigsen and Wimbush 1985: 86f; Salmorbekova and Yemelianova 2010: 216). Private houses furthermore preserved small private libraries; these helped propagate religious knowledge although Central Asia was cut off from the rest of the Islamic world (Roy 2000: 145). Private underground teaching courses were called hujra, which is originally the name for a student-room at a madrasa (Naumkin 2005: 21).

Today in Kyrgyzstan and Tajikistan religious tutoring for children mainly takes place during summer holidays when they visit the local mosque a few hours a day to study the Quran. At the official Almaty Central mosque, children are taught the following subjects: Arabic alphabet, Tajwid (the reading of Quran), Quran, Akida (the basics of Islamic creed), Arabic language, Hadith (the sentences of the Prophet), and Fiqh (awareness; the system of knowledge of right behaviour for Muslims) (Mingisheva: 2011).

In Kazakhstan, religious home-schooling is prohibited except in cases of non-religious necessity (StateDept 2012a). There are seven official madrasas in Kazakhstan and one Islamic University, which is in Almaty. Some Kazakhs study theology in Egypt or Pakistan (Mingisheva 2011). However, Kazakh students who want to study theology in Saudi Arabia need permission from the Kazakh government (Lillis 2013). At Kazakh public schools, 
courses on religion were proscribed until 2013; but in 2014 'traditional religions' will become an obligatory subject (Corley 2013: 2).

Kyrgyzstan allows public schools to teach lessons on 'mainstream' religions (StateDept 2012: 3). Here, many different madrasas operate which are not particularly closely monitored government bodies, and education at madrasas is considered of equal value to that provided at secular secondary schools (interview with a sympathizer of the Gülen movement). Seven official institutes in the country provide higher Islamic education (ARDA KG).

\section{Image 10: Private Religious Class in Bishkek}

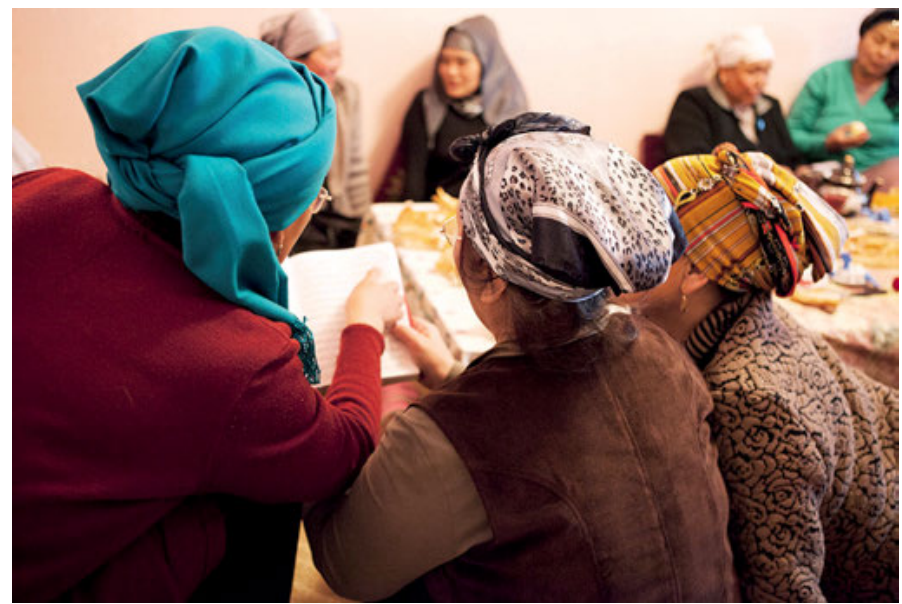

Source: Lisa Harand

I observed a private religious class in Bishkek led by a woman who herself was a student at the Islamic University in Bishkek. Her illegal Quran class comprised around fifteen women who all stem from the same village in South Kyrgyzstan. These women meet once a week in order to discuss religious issues and to learn Islamic subjects such as Arab grammar, reading of Surahs and so on. Their meetings last for several hours with many interruptions for prayers. The teacher has a personal relationship to each of her students and radiates authority. It is interesting to note that the children and husbands of the women in the class meet in their own circles and are instructed by the husband of the woman teacher. The teaching is conservative-Sunni and anti-folk Islam but the women were very open to their west- 
ern guests. They said that they do not have any problems with governmental restrictions on religious instruction.

The Tajik government recently closed private religious schools, as "religious home-schooling outside the immediate family was forbidden" (StateDept: 2010 7f). Yet even within the family, religious beliefs can only be taught, "provided the child expresses a desire to learn" (StateDept 2011: 4). Additionally, the "Law on parental responsibility" banned minors from attending regular religious services in mosques (Freedom House 2013c) although registered mosques are allowed to teach children. Despite this, transportation problems sometimes hinder them from participating in these lessons (StateDept: 2010: 8). Further evidence of Tajikistan's restriction of religious freedoms include the fact that while 'Friday mosques' are allowed to operate madrasas (StateDept 2012c: 3), ${ }^{5}$ teachers on all levels of Islamic education are vetted by the government (Nabiyeva 2013). As for students who wish to study abroad: they need the permission of the MOE, the Committee on Religious Affairs (CRA) and the Ministry of Foreign Affairs (StateDept 2012c: 1). In 2010 around 1,500 students were recalled from abroad - even from the reputable al-Azhar University in Cairo for fear that they could be trained as extremists and terrorists (StateDept 2011: 7; Freedom House 2013c). Subsequently, the limited capabilities of the Tajik religious institutions have failed to integrate them and "some have faced prosecution" (Freedom House 2013c). Obviously fearing foreign influences in all fields now, "in October 2012, the government banned all university students from attending events or conferences organized by international or foreign organizations" (Freedom House 2013c). This appears almost paranoid.

In Uzbekistan, religious classes are permitted neither at homes nor at public schools (StateDept2012d: 2, 4). Meetings of women who teach Islam to children in their homes "were jeopardized as a result of the toughening of official control over any Islam-related gatherings, especially in Uzbekistan's part of the [Ferghana] valley" (Salmorbekova and Yemelianova 2010: 228). The Uzbek religious law "[...] limits religious instruction to officially sanctioned religious schools and state-approved instructors" (StateDept 2012d: 4). Apart from the eleven madrasas and two (University)

5 See the section on registration for the special categorisation of mosques in Tajikistan. 
institutes in Tashkent which provide state approved secondary education, the most populous of the Central Asian countries has "[...] no other officially sanctioned religious instruction for individuals interested in learning about Islam" (StateDept 2012: 4). Graduates of the madrasas are allowed to study at University, because they "provide secondary education on a full range of secular subjects“ (State Dept 2012d: 4). The Islamic University in Tashkent is funded by the government (StateDept 2012d: 2).

Traditional religions are allowed or even form part of the compulsory curriculum in Kazakhstan and Kyrgyzstan. While universities and madrasas are under strict state control in all Central Asian countries, Kyrgyzstan is the exception, where a certain diversity of madrasas seems to exist and private religious classes are attended - despite being prohibited - without fear of state reprisals. All of the Central Asian states closely monitor Islamic students abroad, but the Tajik government went furthest on this issue when it recalled hundreds of students. However, as Uzbeks cannot leave their country without an exit visa, such incidents obviously do not occur there.

In conclusion, restrictions on religious education can be criticized from a human rights perspective. However, Naumkin's comment remains true: what began in Soviet times still continues to this day - parallel Islam and political Islamic groups spread their ideology by means of private tutoring. Indeed, as far back as the 1970s, Salafis started recruiting disciples and teaching them privately, as Naumkin explains (Naumkin 2005: 37): “[...] Salafis began to address 'trusted' audiences and distribute tapes of sermons and lessons to them. They did not, however, call for jihad or direct struggle against the Soviet regime" (Naumkin 2005: 37). Karagiannis also underlines the importance that informal networks play stating that men-groups which gather for tea or lunch at chaykhanas (traditional teahouses) or in private houses are important for recruiting HT-members (Karagiannis 2010. 80). In addition, members of the Gülen movement meet once a week to discuss and pray together as well. All this serves to demonstrate that there is some basis for Central Asian governments' assertion that private religious classes undermine secularity and spread Salafi worldviews (Stephan 2010: 474). 


\subsubsection{Islamic Literature}

The Central Asian states regulate the production, import, export, distribution and content of religious literature to different extents. There are official Muslim publications in all countries. In Kazakhstan, for example, magazines such as 'Iman' and 'Shapaghat-Nur', as well as a monthly journal 'Islam and Civilization' or the Islamic TV channel 'Assyl-Arna' operate in a way acceptable to the government (Mingisheva 2011). Furthermore, there are official websites, such as www.muftyat.kz (Muftiat), www.meshet.kz which provide officially accepted information about Islamic issues.

In Kyrgyzstan religious groups are permitted to "produce, import, export, and distribute religious literature and materials in accordance with established procedures" (StateDept 2012b: 2). However, all religious literature has to be submitted to state experts from the State Committee on Religious Affairs (SCRA). Additionally, "[...] distribution [...] in public locations or by visiting individual household, schools, or other institutions" is prohibited (StateDept 2012b: 2).

The import of religious literature is theoretically allowed in Tajikistan, but religious groups wishing to do so have to hand in copies to the Ministry of Culture in advance (StateDept 2012c: 4). Officials monitor bookstores, newsstands, kiosks and places in front of mosques as well as markets and confiscate unregistered literature (StateDept TJ: 8). The selling of Shia literature, non-hanafi texts and "disks featuring prominent Tajik imams" is impeded (StateDept TJ: 8).

Also in Uzbekistan, law enforcement agencies control bookshops, publishing houses, and border checkpoints in order to detect extremist literature (USDOS). The Uzbek government motivates Uzbek citizens to read only official religious literature:

“One of Uzbekistan's state-run television channels aired a program that urged citizens to read only state-authorized religious books, noting that there are two government authorized publishers of religious literature in Uzbekistan" (USDOS).

Here, the government even maintains a monopoly over religious publications (USDOS). No other Central Asian country goes to such lengths in the control of religious literature. 


\subsection{Institutions InVOLVED With RELIGION}

\subsubsection{Religious Committees}

Theoretically, the official state institutions which deal with religious issues are the state Commissions, Departments and Agencies on Religious Affairs. They prepare religious laws and oversee their implementation. They also analyze religious materials and literature and are responsible for banning them if necessary. In Uzbekistan and Tajikistan the state furthermore distributes official certificates not only to mullahs and dignitaries but also to otin-oyi and bibi-khalife, female leaders who teach children and other women in their homes about Islam (Fathi 2011: 181).

Table 15: Religious Committees

\begin{tabular}{|l|l|l|l|l|}
\hline & Kazakhstan & Kyrgyzstan & Tajikistan & Uzbekistan \\
\hline $\begin{array}{l}\text { Name of } \\
\text { Religious } \\
\text { Committee }\end{array}$ & Agency for & State Com- & Committee on & Council on \\
& Affairs & Religsion for & Religious & Religious \\
& (ARA) & $\begin{array}{l}\text { Affairs } \\
\text { (SCRA) }\end{array}$ & & $\begin{array}{l}\text { Affairs (CRA) } \\
\text { (and Council } \\
\text { for Confessi- } \\
\text { ons) }\end{array}$ \\
& & CRA & & \\
\hline
\end{tabular}

\subsubsection{Muftiates}

In addition to the state agencies and commissions, the independent Central Asian states also adopted the Soviet system of the Muftiate. The Soviet Republics were represented in the SADUM by a qadi (except in Uzbekistan, because the SADUM and the Mufti were located there). After independence, each state established its own succession-institution of the SADUM with its own Mufti (chief legal scholar) (Atkin 2009: 308). The SADUM was "tasked with administering mosques, training ulema, and overseeing other Islamic activities within the Central Asian Republics" (Berkley Centre $\mathrm{h}$ ), and the new institutions inherited these tasks. The internal structure with the election of the Mufti by a council of Islamic clerics (Berkley Centre h) was also adapted from the internal structure of Soviet institutions. 
The Kyrgyz Muftiate, for example, consists of 30 clerics and scholars, a Council of Ulema, and its elected head, the Mufit (Berkley Centre g). All Central Asian states issue fatwas about the correct Islamic practices (for example how to wash before reading namaz and how to wear hijab) ${ }^{6}$ as well as about religious and marriage celebrations. ${ }^{7}$ They for example also inform if hajj has to be delayed because of cases of avian flue in Saudi Arabia. ${ }^{8}$ Fatwas furthermore deal with general issues such as homosexuality, corruption or inform about illegal groups such as Hizb ut-Tahrir. ${ }^{9}$

Theoretically, the Muftiates are not state institutions but independent. However, the contemporary Muftiates are closely controlled by the religious agencies of the independent states, as were the activities of the SADUM by the Soviet Council for the Affairs of Religious Cults. Furthermore, as Roy observes, they are closely controlled and directly subordinated to the Council of Ministers or the presidency (Roy 2000: 158). The Kazakh President Nazarbaev explains the role of the Muftiate as follows:

\footnotetext{
"The spiritual management that joins together 2,228 mosques became the center of cohesion of Muslims. The conditions were created for consolidation of our people around spiritual values and goals" (Nazarbaev in TengriNews 2013).
}

Actually, one of the main tasks of the Muftiate is the supervision and coordination of Muslim groups including the individual mosques. Not surprisingly then, mosques have to be constructed under the supervision of the Muftiate.

6 http://azan.kz/article/show/id/2419.html.

7 http://www.fergananews.com/articles/1424.

8 www.regnum.ru/news/1205674.html.

9 See www.muftyat.kz/ru/fatwa/view?id=18 (homosexuality), www.interfaxreligion.ru/?act=news\&div=45473 (corruption), www.muftyat.kz/ru/fatwa/view ?id=16 (Hizb ut-Tahrir). 


\section{Image 11: Kazakh Muftiate in Almaty}

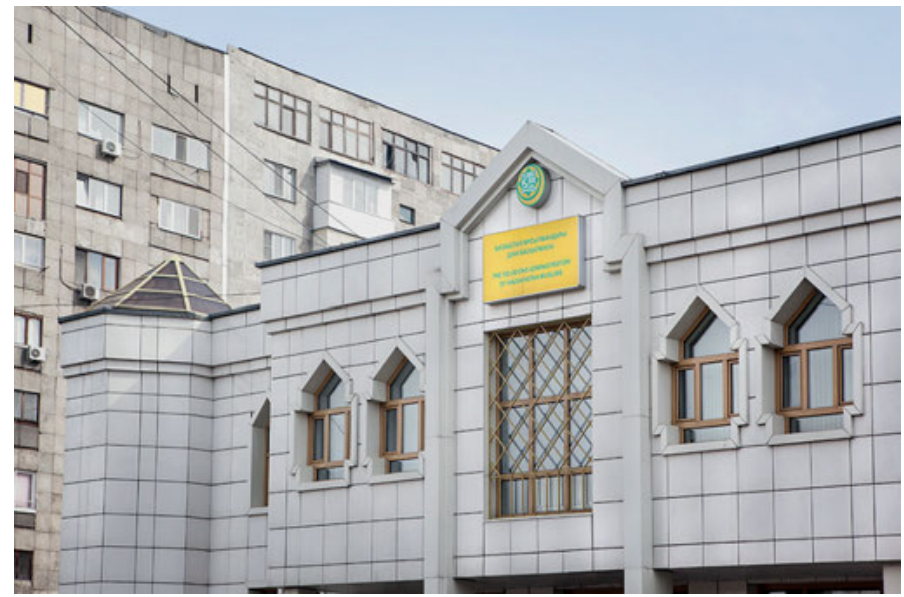

Source: Lisa Harand

As in Soviet times, religious leaders are used by the government to promote state policies among the population. In this regard, Nazarbaev informed religious leaders of the State Strategy 2050 and explained: "the religious officials have to tell the people about the necessity of further work in the best interests of our country" (Nazarbaev in TengriNews 2013). In 2002, the Kazakh government even attempted to make the Muftiate a quasi-official institution "determining which Muslims groups should be allowed to register with the authorities and by approving the construction of new mosques" (Rotar 2004b). This failed because the Kazakh Consitituional Coucil judged the amendment as unconstitutional. Despite this the Muftiate de facto fulfils exactly these tasks.

Furthermore, although imams are theoretically elected by their congregations, the Muftiate appoints them and administers the examinations and background checks for aspiring imams (StateDept 2012a), as is exemplified here with the case of Kyrgyzstan:

"[In Kyrgyzstan] Some 90 percent of imams are appointed by the government, by local government [officials] and offices of the security agency. [...] Even the law says that imams are supposed to be appointed by worshippers at the mosques with the approval of the government. But it is actually the government that selects who 
the imams will be, and when they appoint imams it is clear [the government] controls the mosque through these protégés" (Turajonzoda in Pannier 2010).

Since foreign Islamic funds are banned and governments fear the involvement of foreign fundamentalists, the imams lack independent financial and material resources and are therefore also very dependent on the state in this regard.

Furthermore, the political importance of the Muftiate can have many effects. In Kyrgyzstan, for example, the Chief Mufti has been changed several times since the revolution against Bakiev:

"Former Kyrgyz mufti Murataaly-Hajji Juman-Uulu stepped down after the ouster of Kyrgyz President Kurmanbek Bakiev in early April. Abdushukur Narmatov, who was elected to succeed Juman-Uulu, resigned soon afterwards. Suyun-Hajji Kuluev, who was named as a temporary successor to Narmatov, was severely beaten by unknown assailants during a religious gathering on June 6. The press service of the Muftiat, the country's highest religious authority, told RFE/RL that the attackers shouted that Kuluev must resign.” (RFE/RL 2010).

The implication here is that the government only wants to appoint progovernment muftis. Finally, Ruslanbek Jumagulov was elected new Mufti in June 2010, but after only one month he was replaced by Chubak Zhalilov. Zhalilov resigned after being in office for two years, because of accusations of corruption and organized crime. ${ }^{10}$ His "period saw the biggest number of scandals within the muftiate" (Interfax 2012). Since then, Rahmatilla Egemberdiev has been the new grand Mufti.

The Kyrgyz Muftiate, however, is a special case because it is more heterogeneous than the muftiates of the neighbouring countries. For example, the proselytizing group Tablighi Jama'at, which is allowed to operate legally only in Kyrgyzstan, is represented in the Muftiate. Schenkkan describes that the Office of Davaat is the representative organization of the Jama'at Tablighi and carries out regulating tasks for the daavachis (the name used for members of Tablighi Jama' at in Kyrgyzstan):

10 www.rferl.org/content/kyrgyz-grand-mufti-chubak-hajji-jalilov/24647660.html (13.9.2014). 
"The Office of Daavat, operating within the Muftiate, [...] oversees [the daavtchis] missionary practices. In order to go on a 40-day mission, men must bring three signatures to the Muftiate - one from their families, one from their local imam, and one from their local police precinct. They also must prove they have sufficient funds to support their families while away" (Schenkkan 2011a).

By incorporating them into its structure, the Muftiate can control the daavatchis' activities. The situation in Kyrgyzstan is also unique since even a conflict between the Muftiate and the State Commission on Religious Affairs is possible, something which is unthinkable in the other countries. That is to say that the State Commission and the State Committee on National Security (GKNB), do indeed regard Tablighi Jama'at as fomenting terrorism and compare it to Hizb ut-Tahrir (Schenkkan 2011a).

The history of the Tajik Muftiate is another special case among the Central Asian countries due to the civil war. The career of Turajonzoda serves well to explain this story. He started off as Tajik qazi under Soviet rule, then became second-in-command leader of the opposition during the civil war, and finally deputy prime minister under Rahmon:

"When Tajikistan became independent in late 1991, Turajonzoda was the qazi qalon, the highest spiritual authority for Tajikistan's Muslims. [...] Within a year he was forced to flee the country after becoming an opposition leader" (Pannier 2007b).

Turajonzoda was a member of the IRPT and together with Nuri he led the Tajik opposition (UTO). Because the official clergy supported the opposition, the authorities tried to weaken its influence and established the new Council of Ulama. Only when "they had become convinced that the Council of Ulama would subserviently do as they wished, [did] the authorities [give] it the de facto authority once wielded by the Spiritual Administration" (Rotar 2004b). The person who became the first Mufti of Tajikistan when Turajonzoda fled the country supported Rahmon's winning party but was killed under unclear circumstances in 1996 (Atkin 2009: 308). Turajonzoda only returned to Tajikistan in 1998, after receiving a government post earned in the peace deal and surprisingly resigned from the IRPT in 1999 (Pannier 2007b). However, he still often takes opposing positions towards the government. 
In Tajikistan, for example, unsuitable imams would rapidly be replaced (Rotar 2004b). Here I see that just as in the Soviet period, the authorities prevent independent religious leadership (Khazanov 2005: 32). In this way the government hopes to rid itself of 'uneducated imams' who are regarded as a 'national security issue' by the authorities since it argues that the terrorists mainly recruit those with little or no schooling (Karabayev 2011). Perhaps, though, we should talk not of 'uneducated imams' but rather of 'wrongly educated' imams since the government replaces imams which are not pro-government enough (Salmorbekova and Yemelianova 2010: 236).

The Uzbek MBU is also known to have "denounced and removed Muslim clerics who have allegedly criticized Uzbekistan's regime" (Berkley Center d). As in other domains, with regards to the dependence of the muftiate on the state, in Uzbekistan the situation is most severe. Already when SADUM was replaced with the Muslim Board of Uzbekistan (MBU) immediately following independence, the former Mufti Shamsuddin Babakhanov was replaced with Muhammad Sadiq Muhammad Yusuf. In 1993, however, Yusuf was again replaced with a more loyal person Mukhtar Abdullaev (Naumkin 2005: 70). In this way Salafis were excluded from the Muftiate because the officers feared their influence (Naumkin 2005: 68). Yusuf, for example, was forced out of the country because:

“[...] he was accussed of selling copies of the Quran given as a gift by Saudi Arabia. A bomb was even thrown into his home, though he was not injured in the attack. Independent analysts think he was driven out because the authorities feared his influence and regarded him as a potential rival for power" (Bukharbaeva 2005).

Yusuf returned in 1999 after receiving an official invitation from the government, which was eager to refute allegations of intolerance to Islam $\mathrm{Bu}-$ kharbaeva 2005). Despite this, Yusuf still lives in Saudi Arabia today.

These frequent changes of leadership serve to demonstrate the importance of the Muftiate; an organization which has far-reaching responsibilities:

"In Uzbekistan the Spiritual Administration of Muslims has virtually become a state agency which strictly controls all mosques functioning in the country and even approves the text of Friday addresses" (Rotar 2003). 
A clear hierarchy helps to control the content of individual sermons in Uzbekistan, as the following quote makes clear: "The government controls the muftiate, which in turn controls the Muslim hierarchy, the content of imams sermons, and the volume and substance of published Islamic materials" (StateDept 2012d: 3). Similarly, in Kazakhstan and Tajikistan "the content of the Friday sermons is monitored by the authorities [...]" (Atkin 2009: 308). However, this seems not to have been the case in Kyrgyzstan thus far. Additionally, the governments' hope of controlling every single word uttered by the imams in the official mosques also seems to have been far from realistic. As McGlinchey exemplifies, Uzbek imams' hold on society is strong enough to make even the government considerate of them (McGlinchey 2006). In McGlinchey's view, independent imams still exist and are even capable of challenging the government's power in the most repressive country in Central Asian.

\section{Table 16: Muftiates and Muftis}

\begin{tabular}{|l|l|l|l|l|}
\hline & Kazakhstan & Kyrgyzstan & Tajikistan & Uzbekistan \\
\hline $\begin{array}{l}\text { Name of } \\
\text { Muftiate }\end{array}$ & $\begin{array}{l}\text { The Spiritual } \\
\text { Administration } \\
\text { of Muslims in } \\
\text { Kazakhstan } \\
\text { (SAMK) }\end{array}$ & $\begin{array}{l}\text { Spiritual } \\
\text { Administrati- } \\
\text { on of Muslims } \\
\text { of Kyrgyzstan } \\
\text { (SAMK) }\end{array}$ & $\begin{array}{l}\text { Council of } \\
\text { Ulema } \\
\text { StateDept } \\
2012 \mathrm{c}: 2)\end{array}$ & $\begin{array}{l}\text { Muslim } \\
\text { Board of } \\
\text { Uzbekistan } \\
\text { (MBU) }\end{array}$ \\
\hline $\begin{array}{l}\text { Name of } \\
\text { Mufti }\end{array}$ & $\begin{array}{l}\text { Mayamerov } \\
\text { Erzhan }\end{array}$ & $\begin{array}{l}\text { Rahmatulla } \\
\text { Azhy } \\
\text { Egemberdiev }\end{array}$ & $\begin{array}{l}\text { Saidmukarram } \\
\text { Abdukodizora }\end{array}$ & $\begin{array}{l}\text { Usmonhon } \\
\text { Alimov }\end{array}$ \\
\hline
\end{tabular}

Source: Berkeley Centre and research of Aijamal Huonker

\subsection{Procedures Concerning Religion}

In this section I will take a closer look at two important political processes which directly determine which religious groups are allowed to operate legally in the Central Asian states and who is permitted to practice the Islam- 
ic faith freely. One issue is the registration process of religious organizations and groups. The other is the annual pilgrimage to Mecca, the hajj.

\subsubsection{Registration}

All religious associations in Central Asia have to register with the state. In the words of Bielefeldt, this means that the state provides "for the possibility of obtaining the status of legal personality, which religious or belief groups may need for the exercise of important communitarian aspects of their freedom of religion or belief" (Bielefeldt 2011: 1). In the course of reregistration processes carried out in Kazakhstan and Tajikistan, this has limited the possibilities for religious groups to gain such a legal status and has even involved the banning of organizations. In Kazakhstan, religious associations are only allowed to practice religion if they are registered with the Ministry of Justice. The definition of a religious association by the Kazakh Agency of Religious Affairs (ARA) is the following:

"A voluntary association of citizens of the Republic of Kazakhstan, foreigners and stateless persons in accordance with the legislation of the Republic of Kazakhstan united on the basis of their common interests to meet their spiritual needs" (ARA ${ }^{11}$ )

Every single mosque falls under this definition and therefore all have to register. No other legal entities other than "theological (religious) educational institutions" (ARA) are allowed to engage in religious activities. The registration process in Kazakhstan takes place on three levels (local, regional and national) with a minimum of members on each level (StateDept 2012a: 2). "These requirements make it very difficult for smaller religious groups to register and impossible for any group other than the SAMK [Muftiate] and the Russian Orthodox Church to register at the national level" (StateDep 2012a: 2). The 'association on the basis of common interests', therefore, is not really voluntary and discourages heterogeneity in religious worship.

In the re-registration process carried out in Kazakhstan in 2012, around 600 of formerly almost 3,000 religious organizations were not re-registered. Either they did not try to re-register, no longer existed or were denied regis-

11 www.din.gov.kz/eng/religioznye_obedineniya/?cid=0\&rid=693 (13.9.2014). 
tration due to lack of members or other reasons. Among the 2,229 registered Muslim 'organizations', the majority are mosques which are affiliated with the SAMK (ARDA: KZ). "Those not affiliated with the SAMK, such as the Ahamdiyya Muslim Community, are denied registration" (StateDepta 2012: 3). In 2002 in Kazakhstan, attempts were made to allow only those mosques to register that had been recommended by the Muftiate. (Rotar 2004b). Although this legal proposition failed, the new registration process resulted in the affiliation of $90 \%$ of the legal Muslim religious organizations with the SAMK in 2011 (Berkley Center a). This means that in $90 \%$ of the Kazakh mosques, liturgical orthodoxy is ensured. This coordination has developed only in the last ten years. In the late 1990s only $12 \%$ of the mosques were affiliated with SAMK (Berkley Center a) and in 2004, mosques in South Kazakhstan still "successfully fought off state pressure to submit to the jurisdiction of the Spiritual Administration of Muslims in Kazakhstan" (Rotar 2004b).

As in Kazakhstan, in Kyrgyzstan every single religious community has to register. Yet they can only complete the registration process with the Ministry of Justice after applying to the SCRA:

"SCRA recommends rejection when a religious group does not comply with the law or is considered a threat to national security, social stability, interethnic and interdenominational harmony, public order, health or morality" (StateDept 2012b: 3).

Registration can be therefore be denied for a whole variety of reasons. Indeed, the registration process is cumbersome and foreign religious organizations have to register every year anew (StateDept 2012b: 3). In case of denial of registration, the religious group can reapply or turn to the courts. It is worth pointing out that in Kyrgyzstan unregistered groups often conduct religious ceremonies without government interference, although theoretically they are not allowed to rent a space or hold services (StateDept 2012b: 3).

Tajikistan's religious law of 2009 allows it to regulate the number of mosques in accordance with the number of inhabitants of a place. The law "regulates registration, size, and location of mosques, limiting the number of mosques that may be registered within a given population area" (Yuldoshev 2009b). One central 'Friday mosque' per district or city superordinates the other mosques (StateDept 2012c: 3). Should a mosque not be 
registered, "local authorities can force a place of worship to close and fine its members" (StateDept 2012c: 2). If religious groups do not register, they cannot operate legally in Tajikistan. However, as in Kyrgyzstan, some unregistered places of worship still persist untroubled by the authorities (StateDept 2012c: 2).

In Uzbekistan, not only mosques but also Muslim educational institutions and Islamic centres have to register with the Ministry of Justice and account for 2,048 of the total 2,228 religious congregations (ARDA: UZ). The prerequisite for registration is a minimum of 100 members, and the law "provides strict and burdensome criteria for registration" (StateDept 2012c: $3)$.

I regard the registration process for mosques and religious communities as one of the most influential tools of the Central Asian governments to control religious practice. The most influential tool, however, are lists of banned groups due to their classification as 'extremist' or 'terrorist'. A comparison of these lists will be presented in chapter 9 together with my typology of the Central Asian states' restrictions on religious groups.

\subsubsection{Hajj}

The Central Asian states not only supervise Muslim practices on their own territory but also regulate pilgrimages to Mecca. The annual pilgrimage to the holy sites in Saudi Arabia is an issue which theoretically concerns all Muslim believers because the fifth pillar of Islam obliges every Muslim to travel to Mecca once in their lifetime if he or she can afford this.

Pilgrimages are restricted by the Saudi Arabian Ministry of Hajj which allocates contingents to every country, so that only a limited number of persons can obtain a visa to the holy places. In 2012, for example, only 5,000 out of the 8,000 Kyrgyz pilgrims who wanted to go to Mecca could do so due to the contingent. In fact, many pilgrims wait several years to be selected (Nazarov 2012) which has led to scandals. In Kyrgyzstan, for example, the Muftiate has faced accusations of fraud when organizing the hajj. In order to improve transparency, in 2012 the SAMK revised the rules for participation (Nazarov 2012). Since then, it has been requested that the pilgrims "must owe no debts and perform the five daily prayers", information which is provided to the authorities by inquiring local imams (Nazarov 2012). Furthermore, fees have to be paid to a bank account (cash is no 
longer accepted) and SAMK is now solely responsible for organizing the hajj free from the involvement of parliamentary and community members (Nazarov 2012). The costs for pilgrimage regularly rise. For a Kazakh pilgrim it increased in one year by USD 300. In 2011 Kazakhs paid USD 3,700 for the hajj-trip:

"The amount includes the flight, hotel, transfer (trips to Medina, Kaaba sacred place in the Masjid al-Haram mosque and Arafat valley), accommodation in a tent camp, food two times a day, purchase of a sacrifice animal, medical insurance, and special blue vests distinguishing Kazakhstan from other countries" (Seisenbekova 2011a).

These pilgrim expenses are very high for common people. In addition, women can go to Mecca only if they are accompanied by a man and "there are certain sanitary-medical requirements to pilgrims, as well as age limitations" (Seisenbekova 2011a).

According to CRA restrictions, since 2010 only Tajiks between 18 and 80 have been allowed to perform hajj (Asia-Plus 2013). The CRA decides together with the Council of Ulama who can go to Mecca (Atkin 2009). The CRA furthermore collects the "fees for participation in the hajj and makes all flight and hotel arrangements in Saudi Arabia" (StateDept 2012c: 4). Of those Tajiks who apply for hajj usually most can go, although here too some cases of corruption have been reported in the selection of candidates (StateDept 2012c: 4). In Uzbekistan it is also the government which selects those who can participate in the hajj and provides logistical support and, among other things, charter flights (StateDept 2012d: 3). In 2009, hajj pilgrims from Uzbekistan, Kazakhstan and Kyrgyzstan were also obliged to get a swine flu vaccination. ${ }^{12}$

There are many obstacles that can prevent pilgrims from undertaking the pilgrimage: in addition to the financial constraints and the Saudi Arabian Ministry of Hajj contingents, Central Asian intelligence services are involved with the selection of pilgrims. With the exception of Kyrgyzstan, the intelligence services of all Central Asian countries check the credentials of those applying for pilgrimage (TAZ 6.2.2006).

12 http://www.rferl.org/content/Kazakhs_To_Make_Hajj_While_Turkmen_Will_ Stay_Home_/1873451.html (13.9.2014). 
The Central Asian states' religious laws affect all religious communities and individuals on their territory. I concentrated only on Islam here, but of course also other religions are affected by these state policies. The registration process and regulations concerning religious instruction and religious literature particularly affect religious communities. Other statutory provisions affect the freedom to religious practice of individuals (for example restrictions on clothing and regulations on where one is allowed to pray). 



\section{Comparison of Law Enforcement}

How do the Central Asian states deal with alleged terrorists and religious extremists? Since independence, the Central Asian states have been developing their own national security and counter-terrorism strategies. They have elaborated new national security concepts, adopted laws dealing with terrorism and ratified international treaties in this domain. It would require a great deal of time and effort to scrutinize all these primary sources in detail. For this reason and also because Marat, Omelicheva and Matveeva have written excellent summaries on these issues I mostly rely here on their studies. Erica Marat has written about how the Central Asian military forces have evolved from the Red Army (Marat 2010) and has compared the Central Asian security sector reforms of recent years for the Geneva Centre for the Democratic Control of Armed Forces (DCAF) (Marat 2012) while Mariya Omelicheva (2011) has scrutinized the counterterrorism policies of the Central Asian states in general and of Kazakhstan and Kyrgyzstan in more detail. Anna Matveeva has written several studies primarily on the developments in the Tajik security sector (Matveeva 2005).

Furthermore, I rely on the Military Balance (2012) country profiles for data about military and paramilitary forces. General data and primary resources on security issues are even more difficult to obtain than information about religious regulations in Central Asia. This is not surprising, given the states' high level of authoritarianism. The most difficult deal in this regard is Uzbekistan. There is especially little information about the Uzbek secret police and its internal forces. Some more data is obtainable about the country's military - probably due to the higher degree of international cooperation in this section. 
In my view, it is clear that the purpose of security forces should be to protect citizens from violence - in our case terrorism - and to bring perpetrators to justice. However, this has to be done in accordance with the rule of law. This means that a balance has to be struck between the benefit for the community as a whole and the protection of the human rights of those individuals suspected of terrorism. Important issues in this context are arbitrary arrest, unfair trials, torture by security forces and extrajudicial killings. Recently, a great deal of scientific research has been conducted in this area, and the international community has already tackled the issue on many occasions. However, let us not go into the details of the legal debate. Under the pressure of the international community and in order to fulfil their own responsibilities as signees of United Nations convention against torture, the Central Asian governments have at least taken some measures to prevent the use of torture by their security forces. Furthermore, some progress has been made in improving the situation of detainees in prisons and pre-trial facilities. In spite of these efforts, torture and other ill-treatment are still widespread or even systemic in the Central Asian countries and individuals suspected of being religious extremists are particularly at risk.

In this chapter I will only briefly introduce the counter-terrorism strategies and laws on combating terrorism. I then give an overview of the different security forces dealing with terrorism, and mention their resources and their involvement in international cooperation. Afterwards I will turn to the judiciary, where I look at the general system, the application of penalties, the occurrence of torture and the conditions of imprisonment. Only on this basis will it be possible to judge to what extent the practical repression of religious groups as a precondition for (further) radicalization of individual members takes place in the different countries.

\subsection{SECURIty StRATEgIES AND COUNTER-TERRORISM LAWS}

In the 2011 military doctrine of Kazakhstan, the countering of modern military security threats (such as terrorism and religious extremism) is defined not only as the responsibility of the military but also of other forces and military formations (Marat 2012: 13). As we will see, the main responsibility for fighting terrorism in Kazakhstan falls on the shoulders of the Na- 
tional Security Committee while the most important legal sources for dealing with terrorism are the Law on Combating Terrorism and the Criminal Code (Chapter 9, Article 233 on "Crimes Against Public Safety and Public Order") of Kazakhstan. In January 2013 Nursultan Nazarbayev signed a new law "On amendments and additions to some legislative acts of the Republic of Kazakhstan on counter-terrorism". ${ }^{1}$ The law "represents clear efforts to modernize the country's approach to defining and combating terrorism" and is built on the SCO Convention on Terrorism (2009) and a "model law discussed by the inter-parliamentary assembly of the CIS" in 2009 (McDermott 2013). The law ensures the protection of human rights in the fight against terrorism and combines the latter with confidence-building in civil society. However, the problem remains that

"[...] the state's counter-terrorism capability remains in the hands of an unreformed National Security Committee (KNB) and security structures that have struggled to respond adequately to the explosion of domestic political violence since 2011" (McDermott 2013).

As we will see, there are significant discrepancies between the counterterrorism laws and their implementation in all four countries. One general problem of the legislation is that it does not define the differences "between terrorist or violent extremist groups and criminal groups" (USDOS 2012). Kazakhstan recently pursues a very broad anti-terrorist strategy:

\footnotetext{
“As part of the government's plan to conduct a large-scale campaign to counter radicalization in society, new legislation requires all media outlets in Kazakhstan to assist state bodies in counterterrorism efforts; one consequence of this legislation is that several legitimate opposition media outlets were declared 'extremist' by Kazakhstani courts and ordered to stop operations" (USDOS 2012).
}

Another far-reaching legal means is the new "State Programme to Counter Religious Extremism and Terrorism". For this five-year program from 2013 to 2017 the Kazakh government allocated $\$ 1.3$ billion. The program not only bolsters "existing policies, such as restrictions on religious literature and close monitoring of religious groups and missionary activity", but also in-

1 http://en.trend.az/regions/casia/kazakhstan/2105362.html (13.9.2014). 
troduces new means, "including installing video surveillance in places of worship and monitoring students studying theology abroad" (Lillis 2013). Additionally to the laws and programs focusing on surveillance of religious groups and persecution of alleged extremists and terrorists, the country also takes preventive means. A new law, signed in January 2013 by the President, should introduce "co-operation with religious authorities, antiterrorism education in schools and public information campaigns". Furthermore, measures are being taken in order to "minimize collateral damage and casualties from counter-terrorism operations" (Central Asia Online 2013).

In addition, the state launched a website (www.counter-terror.kz/ru) which reports on terrorism worldwide, in order to improve contact with civil society. The website is supposed to help citizens to gain access to and report to the security services. Another preventive measure, taken in 2013, was the establishment of an "Institute for the Study of Terrorism and Religious Extremism", which is supposed to "bring together sociologists, psychologists and other scholars to study trends in society and to study the influence that films, video games, unemployment, public discontent and lack of youth programmes have on sowing the seeds of extremism" (Isakova 2013). With these far-reaching measures, Kazakhstan is taking a leading role in the region.

The Kyrgyz legal framework for combating terrorism mainly consists of the Law 'On Combating Terrorism' (2006), of the Penal Code and of the Criminal Procedure Code of the Kyrgyz Republic. As is the case in Kazakhstan, in Kyrgyzstan the main counterterrorism bodies are the internal intelligence service and the police under the Ministry of Internal Affairs (MVD) (USDOS KG 2012). As we shall see in the next section, the Central Asian governments cooperate with western states in the military domain. In collaboration with OSCE the Central Asian countries are trying to establish better relations between civil society and security forces as well as government institutions in general. In this regard, Kyrgyzstan has taken the lead by establishing special Public Advisory Councils (PACs) which oversee all Ministerial activities. Amongst others, the new National Security Concept from 2012 was elaborated by "government representatives with military and civilian backgrounds along with elected representatives and members of the Public Advisory Council (PAC)" (Axyonova et al. 2013: 9). The involvement of PACs should ensure better civilian oversight of security is- 
sues, which is reinforced by the parliamentary system adopted by Kyrgyzstan with the new constitution in 2010. However, Axyonova et al. come to the conclusion that, "the decentralisation of political power has only served to slow the pace of SSR [Security Sector Reform]" (Axyonova et al. 2013: 9). Additionally to this, "Kyrgyzstan's modest SSR attempts were stalled due to two violent regime changes in the past six years" (Axyonova et al. 2013: 8). With regards to combating terrorism and respect for human rights in the security sector I have to mention that nonetheless, already in 2009 the Kyrgyz National Security Concept had noted "that respecting human rights and democratic principles is an important part of national security" (Marat 2012: 31).

Whereas Kazakhstan is the most advanced in the transformation of its security sectors according to western standards, "Tajikistan became the last Central Asian country to adopt a post-Soviet military doctrine", doing so only in 2005 (Axyonova et al. 2013: 9). This was due in large part to the long lasting civil war but the difficult process of integrating UTO-forces into the military might also have played a role. Finally, in 2010,

“Tajikistan's legislature was updated to grant parliament rights and responsibilities to sustain the country's defence. In reality, however, neither parliament nor the broader public has access to the security decision-making process, while the new doctrine is mostly symbolic" (Axyonova et al. 2013: 9).

Furthermore, the security reform efforts (also spurred on by western states) to a great extent "have focused on strengthening the country's military and law enforcement structures, often to the detriment of transparency and public oversight" (Axyonova et al. 2013: 10). Rahmon showed, for example, that he can send troops to conflict affected areas without consulting parliament. As Axyonova et al. have noted, "Rakhmon's ability to act without scrutiny demonstrates how the better-trained and equipped special forces are loyal to the president and stand ready to protect his regime" (Axyonova et al. 2013: 10). Despite these facts, the US Department of State comes to the conclusion that under the Law on Combating Terrorism "there have been successful prosecutions of terrorists" (USDOS 2012). It gives cause for serious concern, however, that "a corrupt judicial system and misuse of counterterrorism statutes to suppress legitimate political opposition hampered the effectiveness of the government's counterterrorism efforts" 
(USDOS 2012). In 2012, the Tajik parliament adopted amendments to the "Law on the Fight Against Terrorism" that were then signed by the president (USDOS 2012).

Article 8 of the Uzbek law on "Combat of Terrorism" of 2000 states that the National Security Service coordinates the other state bodies' activities for combating terrorism. Other government bodies involved in fighting terrorism are - like in the other countries - internal troops, border guards and the military. The country started with a new program to train 'antiterrorism specialists' in 2013. Just like the other countries, Uzbekistan recently does not focus on repressive means alone, but aims at enhancing "prevention and at increasing the skills of terrorism-prevention inspectors" (Yeniseyev 2013).

\subsection{SECURITY ForCES}

\subsubsection{Secret Police: (G)KNB}

In all countries the main coordinating body for countering terrorism is the internal intelligence service: the former Soviet Committee for State Security (KGB), today called National Security Committee or National Security Service, which is in all cases directly subordinate to the president. In Kazakhstan, the National Security Committee (KNB) Chairman is "appointed by the President with the consent of the Senate (upper chamber of the Parliament)" (Marat 2012: 10). One of the main tasks of the KNB is the "detection, prevention, and suppression of terrorism" (Marat 2012: 10). To aid them in this task, the KNB has its own Anti-Terror Centre. Moreover, the KNB has its own mobile rapid response unit, 'Arystan' Service, which carries out special operations, including dealing with terrorism. ${ }^{2}$ In fact, KNB specifically targets unregistered and banned Islamic groups (AI 2013). Countering terrorism is regarded by Kazakh authorities as crucial to securing national and regional stability. Apart from the KNB secret police, the ordinary police of the Interior Ministry, the Syrbar Foreign Intelligence Service, the Agency of Religious Affairs (ARA), the Foreign Ministry, the Education Ministry, the Culture Ministry, the General Prosecutor's Office

2 http://en.trend.az/regions/casia/kazakhstan/2109212.html (13.9.2014). 
and local Akims (administration chiefs) are all involved in implementing the new "State Programme to Counter Religious Extremism and Terrorism for 2013-2017” (Corley 2013: 2).

In Kyrgyzstan, the State Security Service was disbanded by the interim government of Rosa Otunbaeva and replaced by the State National Security Service (GKNB). The reason for this was that under Bakiyev's presidency, "the agency was often used to spy on opposition leaders and civil society activists" (Axyonova et al. 2013: 8). Even today in the south of the country, "the situation remains bleak with local law enforcement agencies' continuous surveillance of activists dealing with the post-conflict human rights situation in the Osh region" (Axyonova et al. 2013: 8). As in the other other countries, the Kyrgyz GKNB has far-reaching competences and is legally authorized to,

"[...] trace the activity of public associations, religious organisations, businesses, institutions, as well as the media (regardless of ownership) and individuals suspected of planning, organizing, preparing and/or attempting to violently change the constitutional system, criticise state security operations, seize or usurp state authority, create illegal armed groups, take part in terrorist activities, incite racial, ethnic or religious strife and social discord, and damage the dignity of the country" (Marat 2012: 26).

In order to fulfil these tasks, the GKNB established its own Anti-Terror Centre (ATC) in 2011 (Sultanov 2013b). The Kyrgyz Anti-Terror Center even has its own website: http://www.atc.kg/ With this effort, the GKNB aims to prevent extremist activities by means of information campaigns about its activities in addition to repressive means (Marat 2012: 27).

Generally, information about the security forces of Kazakhstan and Kyrgyzstan is quite easily available online to the public. By contrast, only limited aspects of Tajik and Uzbek legislature are in the public domain. In Tajikistan, the Ministry of Security was the successor institution to the KGB "but does not enjoy the same standing as its much feared predecessor" [...] (Matveeva 2005: 5). According to Axyonova et al. in Tajikistan:

"The Ministry of Security is still considered to be the main intelligence agency. The legal basis for its functions has either not been amended since 2002 or the revised versions are not publicly available" (Axyonova et al. 2013: 8). 
This quote shows how difficult it is to obtain correct information about the Tajik (and Uzbek) security forces - although Axyonova and Marat belong to those international scientists best informed about the issue discussed here, they obviously were not aware that the Ministry of Security was renamed in 2005: Today, the Ministry of Security is called the State Committee on National Security GKNB (WikiLeaks 2007) in Tajikistan as well. Together with the Ministry for Internal Affairs and the Ministry of Defence and other state bodies it is responsible for maintaining security.

Marat provides no further information about the intelligence services of Tajikistan and Uzbekistan (Marat 2012: 1), neither was I able to find more information by my own research. What can be said, though, is that also these countries mainly combat terrorism by means of the State Committee for National Security (Tajikistan) and the National Security Service (Uzbekistan). As I do not have information to the contrary, I will here act on the assumption that these institutions still work in a similar way to those in Kazakhstan and Kyrgyzstan, as this is also the case with other institutions.

\subsubsection{Internal Troops: MVD}

The mission of the Kazakh Ministry of Internal Affairs is to "maintain public order and social security, including during emergency situation and under martial law" (Marat 2012: 7). In Kazakhstan, the dispersion of mass demonstrations, strikes or meetings are the responsibility of the Ministry of Internal Affairs. Furthermore, it is tasked with "preventing terrorism, and rescuing hostages. It may perform some of the functions of the Defence Ministry during emergencies, and it may assist fire-fighters" (Marat 2012: 8).

The Kyrgyz Ministry of the Interior is based on the Georgian model of police reform, which aims to convert Soviet-style militsia into street police (Marat 2012: 24). In order to realize this goal "[...] the OSCE trains and helps the Ministry of Interior to develop a community-based system that would meet international standards of policing" (Marat 2012: 4). However, the Kyrgyz police is not only "deeply corrupt", but the whole Ministry is "still heavily militarized and is authorized to carry out some functions of the Ministry of Defence during emergencies" (Axyonova et al. 2013: 9). The Ministry maintains a special rapid response unit (Trend 2011). 
In 2010, the OSCE office in Dushanbe completed a project "aimed at developing new, or strengthening current relationships between community members, local government officials, and police" (Marat 2012: 35). In the framework of these reforms, the former Tajik militsia was renamed 'police'. The tasks of the riot police under the supervision of the Ministry of Interior are amongst others "to fight terrorism, extremism, drug trafficking and other crimes" (TJ MVD).

Table 17: Paramilitary Resources

\begin{tabular}{|c|c|c|c|c|}
\hline & Kazakhstan & Kyrgyzstan & Tajikistan & Uzbekistan \\
\hline $\begin{array}{l}\text { Total } \\
\text { paramilita- } \\
\text { ry forces }\end{array}$ & 31,500 & 9,500 & 7,500 & up to 20,000 \\
\hline $\begin{array}{l}\text { Paramilita- } \\
\text { ry units }\end{array}$ & $\begin{array}{ll}\text { - } & \text { Govern- } \\
\text { ment Guard } \\
500\end{array}$ & $\begin{array}{ll}\text { - } & \text { Border } \\
& \text { Guards } \\
5,000^{3} \\
\text { - } & \text { Interior } \\
\text { Troops } \\
3,500 \\
\text { - National } \\
\text { Guard } \\
1,000\end{array}$ & $\begin{array}{ll}\text { - } & \text { Interior } \\
\text { Troops } \\
3,800 \\
\text { - } & \text { National } \\
\text { Guard } \\
1,200 \\
\text { - } & \text { Emergen- } \\
\text { cies } \\
\text { Ministry } \\
\text { 2,500 } \\
\text { Border } \\
\text { Guards }\end{array}$ & $\begin{array}{ll}\text { - } & \text { Internal } \\
\text { Security } \\
\text { Troops up } \\
\text { to } 19,000 \\
\text { (Ministry } \\
\text { of Interior) } \\
\text { National } \\
\text { Guard } \\
1,000 \\
\text { (Ministry } \\
\text { of } \\
\text { Defence) }\end{array}$ \\
\hline
\end{tabular}

Source: Military Balance (2012)

3 KGZ conscripts and RUS officers. 


\subsubsection{Military}

The military capabilities of the Central Asian states are not great, especially those of Kyrgyzstan and Tajikistan. Much of the Central Asian states' military equipment comprises leftovers of the Soviet Union. Nonetheless, Kazakhstan is building up its own armaments industry as "Nursultan Nazarbayev, has decided he wants to build a world-class armaments industry" (Kucera 2012). This is in line with his plan both to diversify Kazakhstan's economy and with his multi-vector policy (Kucera 2012). For example, the Turkish president, as well as the defence ministers of Iran and China, participated in the Kazakh biennial defence exposition KADEX (Kucera 2010). In spite of these efforts and although Kazakhstan maintains a quite well-trained rapid-reaction force, the country's armed forces do not meet western training standards (Military Balance 2012: 255). The Military Balance annual report concludes that even in Kazakhstan, the army's Soviet origins are still evident (Military Balance 2012: 255). At any rate, "with a growing focus on counter-terrorist operations, the country is making efforts to develop its Special Forces" (Military Balance 2012: 255). Moreover, it has made "more progress with SSR [Security Sector Reform] than the other Central Asian states" (Axyonova et al. 2013: 6). It is not true, though, that the Kazakh army is totally contract-based, as Axyonova et al. (2013) suppose. However, in 2013 the country started to recruit on a contract basis and plans for 99 percent of the army to consist of contract soldiers by 2016 (KZ Strategy 2050). The engagement in low-intensity conflicts within the state's territory and the prevention as well as combating of terrorist acts are some of the main obligations of the Kazakh military during peacetime (Marat 2012: 13, 16f). In order to complete these tasks, Kazakh armed forces are "deployed in a number of strategic locations, while troops in the strategic western areas are currently being strengthened, according to the doctrine" (Marat 2012: 13).

Kyrgyzstan's military capabilities are limited, although it tries to "progress towards improving national capabilities" by international cooperation (Military Balance 2012: 262). A lack of resources has led to problems in the upkeep of their equipment. For example "a larger number of armed and transport helicopters are in the inventory, but maintenance problems probably mean most of these are not operationally ready" (Military Balance 2012: 262). The violent regime changes in the last years have stalled Kyr- 
gyzstan's modest SSR attempts (Axyonova et al. 2013: 8). In addition to the conscript-based army, Kyrgyzstan maintains

"[...] several contract-based special forces units destined to protect the president, engage in anti-terrorism campaigns and combat drug-trafficking. All special forces have undergone some training abroad, including in Russia, Turkey and the U.S." (Axyonova et al. 2013: 8).

The number of such contract-based military personnel is especially important for assessing the country's military capacity to counter terrorism as conscripts are not useful for being commited for this task. According to the current National Security Concept from 2009, the Kyrgyz military bears responsibility for participating in counter-terrorism efforts and carrying out anti-terrorist operations (Marat 2012: 28f).

With regards to SSR one major problem in Kyrgyzstan is that even now there are many security officials who have a Soviet background and oppose radical changes to the sector (Axyonova et al. 2013: 8). For the same reason, patronage networks and a high level of corruption prevail. Problems include the security forces' role in drug smuggling and their cover ups for organized criminal groups especially in Southern Kyrgyzstan (Axyonova et al. 2013: 10). The same problems persist among the Tajik security forces (Axyonova et al. 2013: 10).

Like its northern neighbour, Tajikistan's armed forces are very weak. The Military Balance report describes the military as "token forces" and says that "the conscript-based land force is hampered by lack of adequate training" (Military Balance 2012: 285). Unlike its northern neighbour, though the Tajik military mainly comprises conscripts. Indeed, "only a few units of the special forces loyal to the president have an arrangement resembling a contract-based service" (Axyonova et al. 2013: 10). The conditions for conscripts serving in the military are extremely bad as they face "hunger, unheated barracks, beatings and regular outbreaks of disease" (EurasiaNet 2012a). For these reasons, the Tajik military not only lacks financial and infrastructural resources but also manpower. Many young men try to evade military service. "Many draftees emigrate, while those that have the means enter university because students are exempt until the end of their studies" (Rahimova in EurasiaNet 2012a). In order to deal with the shortfall of draftees, recruitment officers sometimes "resort to impressment, 
or the quasi-legal kidnapping of military-age men" (EurasiaNet 2012a). This as well as the occurrence of 'devoshchina' - first year conscripts harassed by second year conscripts - are problems inherited from Soviet times; they prevail in the Russian military as well (see for example the regular reports of the NGO 'Soldiers Mothers of St. Peterburg').

By contrast, the Uzbek military does not suffer from a shortage of draftees willing to serve. On the contrary, especially military service at officer's rank is quite favoured among young men (EurasiaNet 2012b) since they receive high salaries: "military officers enjoy salaries roughly fourtimes the national average and also receive generous housing subsidies" (EurasiaNet 2012b). Uzbekistan is the only country where the military service lasts only one year - thereby it avoids the problem of 'devoshchina', a fact that might further improve the conscripts' willingness to serve in the military. Furthermore, Uzbek conscripts have the possibility to serve for a period of only one month. To do so, they have to pay around $\$ 600$ and subsequently become part of the reserve, and "can be called up until they are 27 if the situation requires it" (IWPR 2013b). Around seven out of ten conscripts choose this option, thereby acquiring:

"[...] advantages that come with serving in the military - a direct route into jobs in the police and the tax and customs services. In this authoritarian state, such jobs offer good pay and influence" (IWPR 2013b).

These incentives for Uzbek servicemen are available due to Uzbekistan's high military expenditure. As we see from Table 18, Uzbekistan has (after Kazkahstan) the second highest military expenditure per capita. The Military Balance report states that compared to the other Central Asian countries, Uzbekistan's armed forces are "significantly better equipped than those of its immediate neighbours" (Military Balance 2012: 290). Additionally, "the army is attempting to improve its mobility in order to manage internal security challenges" (Military Balance 2012: 291). 
Table 18: Military Resources

\begin{tabular}{|l|l|l|l|l|}
\hline & Kazakhstan & Kyrgyzstan & Tajikistan & Uzbekistan \\
\hline $\begin{array}{l}\text { Total } \\
\text { paramilitary } \\
\text { forces } \\
\text { (Military } \\
\text { Balance 2012) }\end{array}$ & 49,000 & 10,900 & 8,800 & 67,000 \\
\hline $\begin{array}{l}\text { Terms of } \\
\text { service } \\
\text { conscription } \\
\text { (Military } \\
\text { Balance 2012) }\end{array}$ & 24 months & 18 months & 24 months & 12 months \\
\hline $\begin{array}{l}\text { Military } \\
\text { expenditures } \\
\text { per capita in } \\
\text { US } \$ 4\end{array}$ & 155 & 67 & 35 & 126 \\
\hline
\end{tabular}

It is not surprising that the two most populous Central Asian countries, which are at the same time those with the best economic situation and the highest GDP, are those with the highest military capacities. Kazakhstan's and Uzbekistan's military forces are more numerous and better equipped than those of Kyrgyzstan and Tajikistan.

\subsection{INTERnAtional CoOperation IN THE SECURITY SECTOR}

International cooperation in the military domain is important to all Central Asian countries. Russia has been one of the region's main partners since independence. Other partners include members of the Russian-led Collec-

4 Calculated from military expenditures in \% of GDP and GDP (CIA World Factbook 2010). 
tive Security Treaty Organization (CSTO). The CSTO is a collective security organization, which means that if the territorial integrity or sovereignty of one of its member states is threatened, the collective will take action. Kazakhstan, Kyrgyzstan and Tajikistan were founding partners of the organization in 1991, together with Russia, Belarus and Armenia (CSTO). Uzbekistan has an ambivalent relationship to the collective treaty organization, athough it is a member of it. For example, in 2012 Uzbekistan tried to withdraw from its membership but was not able to do so due to CSTO guigelines (Litovkin 2012).

At a CSTO summit in 2009, the organization "set up a collective rapid reaction force to protect the territorial integrity and sovereignty of the CSTO member states, and to provide security and respond to crisis situations [...]" (RT 2009). Due to the developments in Afghanistan between 1996 and 1998, "the potential of the Treaty was applied to prevent extremists' attempts to destabilize the situation in the region" (CSTO).

Whereas the CSTO integrated non-traditional threats into its security objective, the Shanghai Cooperation Organization (SCO), another regional security organization, has been dealing with internal security threats since its inception: It was founded by the Central Asian states together with Russia and China in the late 1990s. The SCO's main purpose is to fight the "three evils" of terrorism, extremism and separatism, and "is best characterized as a regional organization concerned with non-traditional security" (Aris 2009). Since 2004, years before the CSTO started to do so, it has maintained a Regional Anti-Terrorism Structure (RATS), located in Tashkent. RATS holds counterterrorism trainings and organizes conferences and seminars about terrorism. ${ }^{5}$

Kazakhstan, Kyrgyzstan and Uzbekistan became members of the NATO Partnership for Peace (PfP) in 1994, while Tajikistan joined in 2002 (NATO PfP). ${ }^{6}$ Since $9 / 11$, western powers have become increasingly interested in the region. Indeed, what Matveeva says of Tajikistan is true for the whole region:

"The War on Terror brought new players into security field in a country, previously viewed as a Russia's domain. Since 2001 the US and its allies in the Coalition of the

5 See the RATS' website: http://ecrats.org/en/ (13.9.2014).

6 http://www.nato.int/cps/en/natolive/topics_82584.htm (13.9.2014). 
Willing paid increased attention to security issues in the states bordering Afghanistan [...]" (Matveeva 2005: 16).

Kyrgyzstan, Tajikistan and Uzbekistan in particular have become indispensable partners in the ISAF's war in Afghanistan. Counter-terrorism is a key area of NATO's cooperation with these countries. Furthermore, this cooperation includes support for "political, military and security-sector reforms" (NATO) with additional assistance for Kyrgyzstan and Tajikistan in the domains of "border security, crisis management, and civil emergency planning" (NATO). After presenting the different security treaty organizations in the region, I will now turn to the single countries' relationship with them.

Kazakhstan emphasizes in its 2011 military doctrine that its "chief priority is to strengthen collective and national security through international joint peacekeeping activities" (Marat 2012: 18). Moreover, Kazakhstan "aspires to be a key regional leader in counterterrorism cooperation" (USDOS KZ 2012). In 2012, for example, it undertook the following activities (USDOS KZ 2012):

- Meeting of regional representatives in Almaty to discuss a joint plan of action for the implementation of the UN Global Counter-Terrorism Strategy in Central Asia

- Meeting of expert consultants from the Shanghai Cooperation Organization in Almaty to discuss upcoming joint activities

- Execution of joint counterterrorism drills by Kazakh security forces with counterparts from Russia and Ukraine.

As we will see, apart from the military cooperation with collective security organizations, the Central Asian states host foreign military forces on their territory and/ or cooperate bilaterally with other countries, accepting foreign troops on their territory. Additionally to this, bilateral exercises take place as we can see in the example of the US and Kazakhstan:

"The United States and Kazakhstan affirm their continued collaboration in support of stability in the region, including through our joint efforts on counterterrorism. Our commitment to security cooperation is demonstrated by activities such as U.S. support for Kazakhstan's peacekeeping brigade and the annual military exercise Steppe Eagle" (USDOS 2012). 
Furthermore, the US cooperate with Kazakh police forces in the domain of training and by providing "logistical support in the form of body armor, special helmets, binoculars, masks and other equipment" as the Kazakh Ministry of Internal Affairs explains (KZ MIA 2013). The importance of international cooperation for the Central Asian states is unlikely to diminish in the near future. For example, the Kazakh military doctrine of 2007 advocates "intensified cooperation with the Russia-led Collective Security Treaty Organization (CSTO) as well as with China, the United States, and NATO's Partnership for Peace (PfP) programme" (Marat 2012: 12). As mandated by the CSTO in 2009, Kazakhstan has already established its Collective Rapid Reaction Forces units.

Kyrgyzstan also avails itself of diverse networks in the security domain. The new Kyrgyz National Security Concept of 2009 states that "to fit international terrorism, separatism, and religious extremism [...] the country collaborates with the CIS; CSTO, SCO, OSCE, EU, etc." (Marat 2012: 31). For example, the Kyrgyz State Committee for National Security (GKNB) Anti-Terrorist Centre (ATC) works together with the OSCE and SCO (Sultanov 2013a). In the framework of these organizations, the country also participates in military exercises:

"Despite their weakness, Kyrgyzstan's armed forces participate in Shanghai Cooperation Organisation exercises, such as the SCO's counter-terrorism exercises, and has hosted SCO exercises within its training areas, indicating the ability to offer command and control facilities to disparate military units" (Military Balance 2012: 262).

After 9/11, the US expanded its Antiterrorism Assistance Program (ATA) to Kyrgyzstan, Uzbekistan and Kazakhstan. The US has rented Manasairport in Kyrgyzstan since 2001. In 2009, the Kyrgyz parliament decided to close the base but later revised this decision (RT 2009a). Today, the airport is still important for the transit of troops and supplies to Afghanistan (RT 2009a). In fact, Kyrgyzstan is the only country in the world that hosts both US and Russian troops. The latter are stationed at Kant airport, near Bishkek and in the south of the country (RT 2009b).

Like the Kyrgyz armed forces, the relatively weak Tajik military is also a member of regional security organizations although "there is little capaci- 
ty to deploy other than token forces [...] the Tajik military is an active participant in CSTO and SCO military exercises" (Military Balance 2012: 285). Despite the fact that in the event of terrorist threats, the Tajik Military would act theoretically as a CSTO-member, "the understanding is that in case of a serious attack by 'international terrorists' it will be the Russian Armed Forces based in Tajikistan who would resist it" (Mateveeva 2005: 9). To this end the Russian 201st Motor-Rifle Division is based in three different locations (Dushanbe, Qurgon Teppa and Kulob) in Tajikistan and "Russia reached a deal to keep troops [...] through 2042" (Freedom House 2013c, Yuldoshev 2013). Tajikistan also plays an especially important role in supporting Allied operations in Afghanistan through the hosting of French military aircraft at Dushanbe Airport (NATO). Additionally to Russia and France, India maintains an airbase in Tajikistan (Military Balance 2012: 285). The US have air-space rights and refuelling privileges at Tajik airfields (Beehner 2005).

Axyonova et al. argue that international military aid to Tajikistan helps the president to maintain his rigid control over the country and the West has accepted this compromise for fear of spill-over effects from Afghanistan. Thus short term stability takes precedence over the need to address corruption and establish good governance:

“This risks undermining Tajikistan's political and economic development by further strengthening the president's political control over the security sector at the expense of democratic development" (Matveeva 2005).

In addition to military assistance, in the domain of intelligence, "according to Tajikistan's Ministry of Justice, the country collaborates with ODIHR, the U.S. Helsinki Committee, and the U.S. Embassy on intelligence" (Marat 2012: 36). Because of its immediate neighbourhood and the mountaineous border it shares with Afghanistan, Tajikistan is of great strategic importance for the West. The international community therefore seems to rank stability over human rights concerns - a similar situation is observable in Uzbekistan.

Military cooperation between the US and Uzbekistan also originated from pragmatic military strategic considerations. From 9/11 until 2005 the US spent $\$ 150$ million in annual aid packages to Uzbekistan (Beehner 2005). However, the cooperation of Uzbekistan with the US in specific and 
with NATO in general has experienced even more ups and downs than the renting of Manas-airport by the US. For example, because of the events in Andijan, the cooperation between NATO and Uzbekistan was interrupted between 2005 to 2010, but was reaffirmed afterwards (NATO). Similarly, in 2005 US forces were recalled from the Karshi and Khanabad (K2) airbase, which they had used for Operation Enduring Freedom in Afghanistan. The reasons for the withdrawal might have been due to US criticism of the Uzbek government's behaviour in Andijan combined with the US airlifting of Uzbek refugees in the course of this event as well as the newly demanded loans for the airport which were initially provided for free by Uzbekistan. However, the vitally important geographical location of the country for the war in Afghanistan provided a strong incentive to overcome all these problems:

"Uzbekistan has largely repaired relations with the EU and United States in recent years, in part by agreeing to the overland transportation of NATO supplies to, and increasingly from, Afghanistan. The rapprochement continued in 2012, as the United States again approved waivers for Uzbekistan on some human rights-related sanctions, and high-level visits between U.S., European, and Uzbek officials increased. Nevertheless, Tashkent continued to resist public diplomacy efforts and educational exchanges, and to carefully restrict Uzbeks' access to the outside world" (Freedom House 2013d).

In addition, Germany has now put itself on good terms with the authoritarian regime and still uses the airfield at Termez in Uzbekistan. "According to some German reports, the country has paid an average of 11 million euros since 2002 for basing privileges" (Nichol 2013b: 22). Despite its often changing foreign policies, Uzbekistan also participates in the joint exercises of SCO and CSTO (Military Balance 2012: 291). Despite the fact that Uzbekistan's international security politics are changing on a regular basis, the country is still an ally of the West as well as of Russia and China because of its rather good military and transports infrastructures (especially important for the withdrawl of US-forces from Afghanistan in 2014) and its strategic location. 


\subsection{COMPARISON OF THE JUDICIARY: TRIALS AND TORTURE}

The enforcement of religious laws has a lot to do with the general practice of the security forces and their lack of respect for human rights. Detainees suspected of belonging to a banned religious or extremist group are especially prone to maltreatment when arrested and during interrogation processes. For example in Kazakhstan, "the process of reregistration was used to cull around one-third of the country's religious organizations, exposing unregistered believers to arrest and prosecution" (Freedom House 2013a). Similarly, the Tajik state treats "unregistered religious activity as a criminal offense" (Freedom House 2013c). Indeed, the United Nations Committee against Torture found that in Tajikistan "members of banned Islamic groups [...] are reportedly held in incommunicado detention and solitary confinement, and [are] subjected to torture and/or ill-treatment by law enforcement officials" (AI 2013: 51). Regarding the crueller treatment of members of religious groups, Amnesty International is especially concerned about the situation in Uzbekistan, where "thousands of devout Muslims sentenced [...] after unfair trials for alleged membership of banned Islamist organizations are being held in conditions which amount to cruel, inhuman or degrading treatment" (AI 2013: 55). This seems a rather harsh penalty for not registering religious activity and is indistinguishable from religious persecution:

"(The Uzbek government) treats unregistered religious activity as a criminal offense. [...] Suspected members of banned Muslim organizations and their relatives have been subjected to arrest, interrogation, and torture." (Freedom House 2013d).

The fact that not only members of banned groups but also their relatives have to fear arrest, interrogation and torture means that collective responsibility or even clan custody is aplied. This is a law enforcement strategy that terrorizes the population. On top of this, law enforcement authorities also "routinely justify the arrest of suspected Islamic extremists or political opponents by planting contraband or filing dubious charges of financial wrongdoing" (FH 2013). I show in this chapter that the already theoretically discriminating religious laws are accompanied by the even crueller practices of security forces. 


\subsubsection{Judicial System: Independence and Penalties}

The judicial systems of the Central Asian states are problematic due to corruption, subservience to their respective presidents and a lack of independence. Freedom House summarizes the situations in the different countries as follows:

- Kazakhstan: "The constitution makes the judiciary subservient to the executive branch. Judges are subject to political bias, and corruption is evident throughout the judicial system" (Freedom House 2013a).

- Kyrgyzstan: "[...] serious flaws remained in the treatment of national minorities, due process, prevention of and accountability for torture, and judicial independence" (Freedom House 2012b)

- Tajikistan: "The judiciary lacks independence. Many judges are poorly trained and inexperienced, and bribery is reportedly widespread" (Freedom House 2013c).

- Uzbekistan: "The judiciary is subservient to the president, who appoints all judges and can remove them at any time. The creation in 2008 of a Lawyers' Chamber with compulsory membership increased state control over the legal profession" (FH 2013d).

Convicted members of banned and extremist groups face trials which differ according to the extent to which the judiciary depends on the government and president. In this regard, Uzbekistan seems to fare the worst: according to the constitution, the Uzbek president is authorized to approve and dismiss judges as well as to declare state emergencies (Berklery Center d). "Since independence, Karimov has used his authority over the judicial system to persecute political dissenters in the name of "state emergencies", (Berkley Center e). I already introduced in section 7.2 how Karimov misuses his constitutional power to crack down on his opponents.

Apart from such abuses of power, it is insightful to look at the legal sentences for detained terrorists. Today, Kazakhstan is the last of the four countries in my study where the death penalty is still reserved for crimes "committed in exceptional circumstances" or under military law. This means that "Terrorism with loss of life is the only Article in the Criminal Code which provides for the death penalty in peacetime" (AI 2013: 47). In Tajikistan the death penalty theoretically still exists for all crimes, but the 
country's last execution took place in 2004 and therefore is classified by Amnesty International as "abolitionist in practice". Until recently, around 100 persons were executed every year in Uzbekistan, but the country abandoned the death penalty in 2008 for all crimes. The last execution in Uzbekistan is reported by Amnesty International to have taken place in 2005. In Kyrgyzstan, the death penalty has also been abolished for all crimes.

In addition to state executions, suspected terrorists are often killed in extrajudicial killings in Kazakhstan. Kazakh parliamentarians criticized "law enforcement bodies for their tendency to kill all suspected terrorists in shootouts, rather than capture them alive for questioning" (USDOS 2012). This might also be the case in the other countries. In Tajikistan for example, such incidents are reported, as well. However, so far I have not found enough reliable data regarding this issue to make a country comparison.

\subsubsection{Torture, III-Treatment and Conditions of Imprisonment}

The Political Terror Scale is an aggregated index that measures the "levels of political violence and terror" that a country experiences in a particular year based on a 5-level "terror scale originally developed by Freedom House" (PTS). It points to the range of state violence and to the dimension of the population that is affected by abuses of physical integrity rights. The index is based on Amnesty International and US State Department annual reports. In 2012, all Central Asian Countries were assigned 'level 3', which means,

"There is extensive political imprisonment, or a recent history of such imprisonment. Execution or other political murders and brutality may be common. Unlimited detention, with or without a trial, for political views is accepted" (PTS).

To be rated as level 3, torture and beatings must be more than exceptional and political murder more than rare (rare = level 2). However, with such a rating, murders, disappearances and torture have not yet become a common part of life (common part of life = level 4 ). As the index is very much dependent on annual reports and therefore on current events, the measure mostly reflects violent incidents. For example, the index shows the very bad rating of 4 for Uzbekistan in the year of the Andijan events (2005) and for Kyrgyzstan in 2010 in the year of governmental overthrow. Because I 
am more interested in the general situation in the countries and the latent prevalence of state violence rather than in current political incidents, I present the average numbers of the index in Table 20.

Table 19: Political Terror Scale

\begin{tabular}{|l|l|l|l|l|}
\hline & Kazakhstan & Kyrgyzstan & Tajikistan & Uzbekistan \\
\hline \multicolumn{5}{|l|}{ Political Terror Scale (PTS) (1 - 5, lower means fewer human rights abuses) } \\
\hline $\begin{array}{l}\text { Average } \\
\text { PTS values } \\
\text { 1993-2012 }\end{array}$ & 2.40 & 2.38 & 2.75 & 2.83 \\
\hline
\end{tabular}

Comparing the average values of the Central Asian states, we see that in Kyrgyzstan and Kazakhstan political violence by state bodies is least spread, whereas it is more common in Tajikistan and especially in Uzbekistan. In order to illustrate what 'state violence' means more concretely, I will now go into some details.

The protest of oil-workers in Zhanaozen (see section 6.2.1) illustrates how law is enforced in Kazakhstan: "at least 15 people were killed and more than 100 seriously injured" (AI 2013: 48). Lethal force even was commanded:

"Kazakhstan's Interior Minister [...] has admitted that during the riots police forces were ordered to shoot and kill the protesters and said that any further riots organised by armed protesters will be countered with similar means" (see Marat 2012: 3).

In the wake of the Zhanaozen protest, the torture of detainees held incommunicado in police custody was reported, however, independent monitors had no access to the detainees and therefore could not verify these allegations (AI 2013: 48). "At least one man was alleged to have died as a result of the torture he was subjected to in police custody" (AI 2013: 48). Bad conditions of imprisonment lead to prison-riots which erupt on a regular basis in Kazakhstan. In the city of Balkash in southern Kazakhstan, even "sixteen prisoners died when they blew themselves up after an abortive at- 
tempt to break out of a jail" in 2011 (NewsOK 2011). Such attempts have harsh consequences for those involved in the riots:

"Relatives of inmates say those involved in the unrest were subsequently badly beaten by prison officials. In August 2010, two inmates were killed after police intervened at another prison in Kazakhstan's north to quell a mass brawl" (NewsOK 2011)

Not only physical violence poses a problems in Central Asian prisons more general conditions in penitentiary institutions are very harsh in all four countries, as well. Whereas physical conditions such as poor food supply and the overcrowding of cells seem to be more severe in Uzbekistan and Tajikistan, denial of contacts with the outside world and a whole system geared more towards punishment than reintegration into the society is a problem in all four countries (see UN reports on torture).

In order to gain a better understanding of the Kyrgyz judicial system it is informative to look at the aftermath of the Osh 2010 events. "Since mid2011, lawyers defending ethnic Uzbeks accused of participation in the June 2010 events have been threatened and physically attacked, even in the courtroom" (AI, 2013: 49). Torture of detainees is routine: "while people are being apprehended in the street, or on their way to detention centres, while their houses are searched, during interrogation, and in pre-charge detention facilities" (AI 2013: 49). Ethnic Uzbeks from the south are particularly prone to torture and ill-treatment by police officers working for the Ministry of Internal Affairs (AI 2013: 49). Theoretically, Kyrgyzstan has adopted a policy of zero tolerance towards torture, which "is intended to serve as model to end impunity for torture in the region as well" (Moreno 2012). However, a significant gap persists between the theoretical framework and the implementation of the new strategy.

Similarly, Tajikistan introduced "a new article in the criminal code criminalizing torture" in 2012 (AI 2013: 51). However, also here, torture and ill-treatment still often take place "during the first hours of interrogation in police custody as well as in temporary and pre-trial detention facilities run by the State Committee of National Security [SCNS] and the Department for the Fight against Organized Crime" (AI 2013: 51). Especially members of the IRPT are confronted with violence: in 2013, the deputy head of the party was heavily beaten by unknown men on the street and in 
2014 a member of party died in police custody in Isfara under unclear circumstances (Asia Plus 2014).

According to the UN Special Rapporteur on Torture, in Uzbekistan, torture is systematically used. For this reason, the European Court of Human Rights has prohibited the return of individuals to Uzbekistan, "especially those accused of membership of Islamist parties or groups that are banned in the country, on the basis that they would be at risk of torture and other ill-treatment if returned" (AI 2013: 55). 


\section{Typology of Religious and Counter- Terrorism Politics}

\subsection{Typology of State Regulation of FOLK ISLAM}

Keeping the dire (and since independence even deteriorating) socialeconomic situation in Kyrgyzstan and Tajikistan in mind, it is not surprising that in these two countries the percentage of those who regard attacks against civilians in the defence of Islam as justified is highest (see sections 1.2 and 6.2.5 as well as Figure 7 for explanation).

Despite this, the PEW data on Uzbekistan should be interpreted carefully. Taking the whole political and religious context into consideration, it seems logical to conclude that the low percentage of Muslims who say that violence against civilians in order to defend Islam can be justified is a reflection of the reluctance of respondents to give a positive answer to this question, which is most likely a result of the strong state surveillance and repression of Muslims. People here even fear to practice the officially accepted Islam. Although Uzbekistan used to be a beacon of Islam in Central Asia nowadays Uzbeks rarely visit mosques or read namaz. I can only assume that this country, which was traditionally regarded as the most devout of the Central Asian nations, has such a low number of everyday practising Muslims and such a large discrepancy between every day praying Muslims and mosque attendance because of the restrictive religious policies (see Figure 11). 
Figure 11: Frequency of Prayers and Visitation of Religious Services

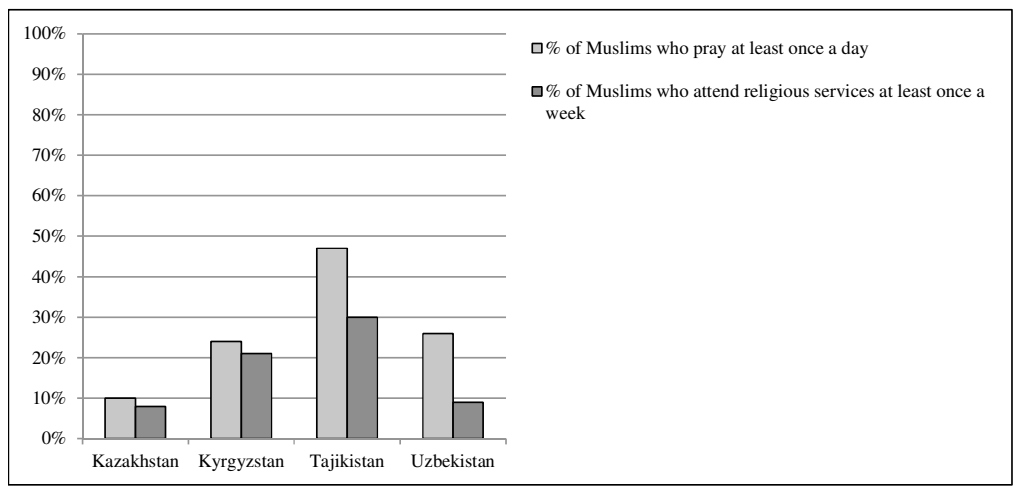

Source: PEW 2012

My assumption that a discrepancy between every day praying Muslims and mosque attendance is an indicator of tight restrictions on religion in each respective country is confirmed by data concerning the perception of religious freedom in these countries. In Tajikistan and Uzbekistan where the discrepancy between praying and mosque attendance is the greatest, up to $10 \%$ of the Muslim population feel either not very free or not at all free to practice religion (see Figure 12).

Figure 12: Perception of Religious Policies by Central Asian Muslims

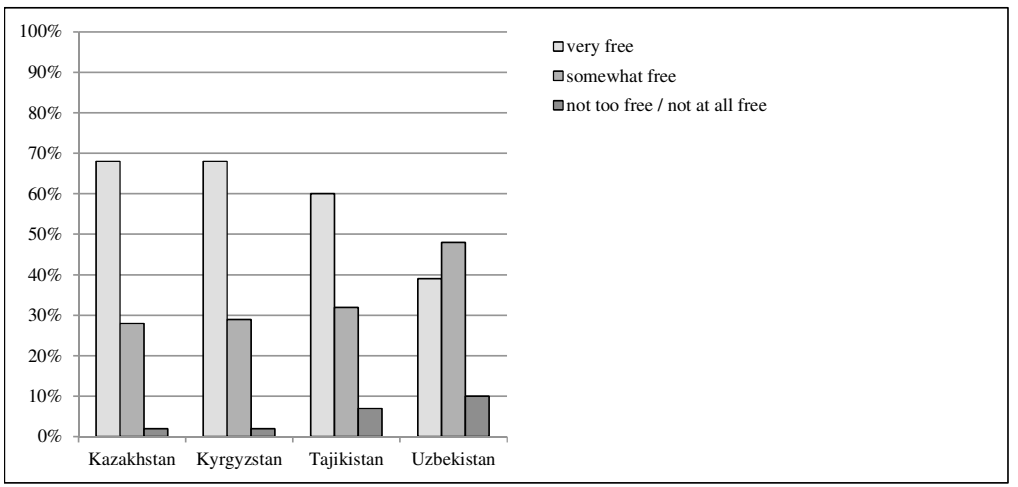

Source: PEW 2013 
Furthermore, the countries where Muslims feel least free to practice religion - Tajikistan and Uzbekistan - are those with the highest percentage of Muslims (both around $90 \%$ as was shown in Table 5). They were also the first two to introduce restrictive religious policies and the countries which went furthest in their attempts to control traditional Islam: Uzbekistan exercises total control over all religious activities while Tajikistan has ascribed a 'special' status to Hanafi madhab. Uzbekistan and Tajikistan are also those two countries which officially prohibited the wearing of hijab at schools (there are reports of such restrictions in Kazakhstan and Kyrgyzstan as well but only from school administrations which do not constitute legal prohibitions on a national level). In order to protect their countries from terrorism Tajikistan and Uzbekistan have even introduced travel restrictions. Indeed, Uzbekistan is "the only former Soviet administration to still require exit visas for its citizens to leave the country" (Blua 2013) while in the case of Tajikistan hundreds of students were recalled from abroad as I showed in 7.3.2. Kazakhstan has closed the gap on these two countries on the legal level just recently with its new "State Programme to Counter Religious Extremism and Terrorism for 2013-2017". So far, however, around two thirds of both Kazakh and Kyrgyz Muslims still feel free to practice religion. Nevertheless, Figure 12 not only has something to say about the religious policies Central Asian states but also about the acceptance of religious policies in the population. As Kazakhstan and Kyrgyzstan are still presumed to be the least religious Central Asian countries, it is no surprise that governmental restrictions on religion there are a cause for concern for fewer people.

To sum up, Uzbekistan and Tajikistan's legislation is most restrictive with regards to religious issues. But despite these differences among the Central Asian countries, it is worth remarking that all of them interfere with traditional Islam to a great extent as it is the only interpretation of Islam that is officially sanctioned. The Uzbek Muftiate, for example, oversees important holy sites which exclude non-official muftis and shayks. Furthermore the Uzbek security forces arrested the regional leader of the Naqshbandiyah tariqa in 1999 under the accusation of Wahhabism - after a two-year sentence he received amnesty and immigrated to Kazakhstan (interview with Ponomarev). In Kazakhstan, however, new Sufi orders are unwelcome and incidents of detained Sufis have been reported as well, even though the country has appropriated historical Sufi figures such as 
Ahmad Yasawi for its own ends. In regard of folk Islam, all Central Asian states prohibit private religious classes. Such instruction, which can even be considered the traditional method of religious education in the region, has been criminalized throughout Central Asia due to the impossibility of controlling its content.

I therefore conclude that state restrictions on Islam not only pertain to non-traditional but also to traditional Islam. Private religious classes, for example, are a typical Central Asian form of religious education and practice and are held by many of the traditional and non-traditional groups, but they are prohibited in all Central Asian states.

Finally, the Central Asian governments can also be identified as actors contributing to the revival of Islam as they use the term traditional Islam in order to build a national ideology and maintain tight control over religion.

\subsection{Typology of State Regulation of NON-TRADITIONAL GROUPS}

I now give a final overview of the 'non-traditional' groups that have been banned in the Central Asian countries and how security forces and judiciary deal with members of these groups. In Table 20, a cross indicates that a group has been banned by a country while a tick indicates that the group is legal and has even established itself in state institutions to some extent (Tablighi Jama'at in the Kyrgyz Muftiate and the Islamic Revival Party in the Tajik parliament).

Table 20: Legal Status of Non-Traditional Islamic Groups in Central Asia $(\bullet=$ legal; $x=$ illegal $)$

\begin{tabular}{|l|c|c|c|c|}
\hline & Kazakhstan & Kyrgyzstan & Tajikistan & Uzbekistan \\
\hline Modernists: FG & $\checkmark$ & $\checkmark$ & $\checkmark$ & $\mathrm{x}$ \\
\hline Fundamentalists: TJ & $\mathrm{x}$ & $\checkmark$ & $\mathrm{x}$ & $\mathrm{x}$ \\
\hline Islamists: IRP & $\mathrm{x}$ & $\mathrm{x}$ & $\checkmark$ & $\mathrm{x}$ \\
\hline Islamists: HT & $\mathrm{x}$ & $\mathrm{x}$ & $\mathrm{x}$ & $\mathrm{x}$ \\
\hline Jihadists: IMU & $\mathrm{x}$ & $\mathrm{x}$ & $\mathrm{x}$ & $\mathrm{x}$ \\
\hline
\end{tabular}


I now summarize the situation in each country and then summarize the legal situation of all groups in the different countries.

\section{Country-Comparison:}

- Kazakhstan has become the second most repressive country in terms of religious freedom since it banned Tablighi Jama' at in early 2013. (Up until this point this apolitical fundamentalist movement had not been registered but was tacitly accepted). The only non-traditional group included in this study that is so far still legal in Kazakhstan is the Gülen movement. There is evidence that Gülen schools are even welcomed by Kazakh and Kyrgyz governments and only feared because of panTurkish tendencies in Tajikistan and Uzbekistan.

- Kyrgyzstan is the only country that tolerates apolitical Salafis, whereas it outlaws all Islamist groups - whether they are violent or non-violent.

- Tajikistan's religious politics are less consistent than those of Kyrgyzstan. Among the Islamists, Tajikistan tolerates the former civil-war party IRPT but has banned the pacifist HT. And despite the partial acceptance of political Islam, apolitical Salafis such as the Tablighi Jama' at are persecuted.

- Uzbekistan was the first Central Asian state to refer to radical Islam as a national security threat as early as the 1990s. It still holds a leading position in the suppression of all Salafi movements. Not only Islamists but also all fundamentalist and modernist groups are persecuted: even members of Nurcu and Gülen movements have spent many years in prison. Nonetheless, Uzbekistan has made some attempts to improve its human-rights image among the international community following the 2005 Andijan events though this did not bring any real changes for religious Muslims.

\section{Group-Comparison:}

- The jihadist Islamic Movement of Uzbekistan (IMU) and its successor organizations such as the Islamic Jihad Union (IJU) are banned in all states. This is not surprising and from a human security point of view must be considered as necessary since they are openly hostile towards 
the contemporary regimes and overtly apply violence against civilians in order to reach their goals.

- Islamist groups such as Hizb ut-Tahrir (HT) and Islamic Revival Party (IRP) face different situations among the Central Asian countries. HT today is persecuted throughout Central Asia. However, in Kazakhstan and Kyrgyzstan the Islamist party was not banned up until the early 2000s. In Kyrgyzstan, the group was only banned in 2003 and treated quite moderately until the regime change in 2005 (Taji-Farouki 2009: 423). In Tajikistan and Uzbekistan members of the group are harshly persecuted and arrested even for the possession of leaflets: Rotar estimates that in 2004150 members were detained in Tajikistan and 5,000 in Uzbekistan (Rotar 2004b; see also Khalid 2007: 161).

The Islamic Revival Party (IRP) is banned in Kazakhstan, Kyrgyzstan and Uzbekistan. Although the IRPT is legal in Tajikistan it is subject to severe state control. The parliamentary party has to report the names of its members to the government and according to the party it often happens that state officers and imams who are members of the party subsequently lose their jobs (interviews with IRPT members). The persecution that party members face can be even more severe as examples of beaten and even killed party members show.

- Fundamentalist Tablighi Jama' at was banned in Uzbekistan in 2004, in Tajikistan in 2006 and Kazakhstan in 2013. For example, in Tajikistan mass arrests of Tablighi members took place in 2009 when 124 people were arrested in one single raid on a mosque in Dushanbe: "Although most were soon released, four alleged members of Tablighi Jamaat [...] face trial on charges of inciting religious, national and ethnic hatred" (Hamrabaeva 2009). In Uzbekistan and Tajikistan the practice of Tablighi Jama'at "is strictly prohibited and persecuted" (Nasritdinov 2012: 162). In Kazakhstan, the group is still very active and popular despite being illegal and censored (Nasritdinov 2012: 163). Nasritdinov estimates that at a meeting in India where he was present around $70 \%$ of all Tablighis from CIS countries were Kazakhs (Nasritdinov 2012: 163). Unlike in the other Central Asian countries in Kyrgyzstan, the group is even represented in the Muftiate.

- Modernist movements such as Nurcu and the Fetullah Gülen movements are not prohibited in Kazakhstan, Kyrgyzstan and Tajikistan. However, the movement is under close government control in Tajiki- 
stan. Only in Uzbekistan has the movement had to close its schools - as early as the 1990 s - and only here are members of the movement regularly arrested and convicted. For example, in 2009, three people were sentenced to eight years in prison for their membership in the Nur movement while an imam of Namangan province was sentenced to twelve years (Yadgarova 2009).

To sum up, Kyrgyzstan and Tajikistan are more open to moderate Salafis with providing legal status to the Islamic Revival Party (Tajikistan) and Tablighi Jama'at (Kyrgyzstan), respectively. These two countries as well as Kazakhstan furthermore accept Nurucs and the Fetullah Gülen movement. The most restrictive country is Uzbekistan, where none of the here mentioned Salafi groups are tolerated

Not only do the Central Asian countries differ in their views regarding which religious groups to ban or tolerate, but their views also differ regarding the extent to which the religious laws should be implemented: this seems to be due to the different means that governments have at their disposal for implementing their policies. Uzbekistan and Kazakhstan are best equipped to put their restrictive laws into action which can probably explain their higher ARDA Religious Persecution Index (see Table 21): ${ }^{1}$ With regards to religious issues, Kyrgyzstan and Tajikistan show a much lower level of persecution (1.0) than Kazakhstan (3.0) while Uzbekistan witnesses the highest persecution on religious grounds with an index of 6.0.

Table 21: Religious Persecution Index

\begin{tabular}{|l|l|l|l|l|}
\hline & Kazakhstan & Kyrgyzstan & Tajikistan & Uzbekistan \\
\hline \multicolumn{5}{|l|}{ Religious Persecution Index (ARDA) (0-10, lower means less persecution) } \\
\hline Value 2013 & 3.0 & 1.0 & 1.0 & 6.0 \\
\hline
\end{tabular}

1 The Religious Persecution Index is devised by the Association of Religion Data Archives (ARDA) and describes persecution on religious grounds more precisely than the general Political Terror Scale. It measures the "average number of people physically abused or displaced due to their religion" and is based on recent U.S. State Department's International Religious Freedom reports (ARDA). 
In addition to the Religious Persecution Index, the following estimations indicate that in Kazakhstan radical Isalm has become a security issue and that the country has closed up to Uzbekistan and Tajikistan. Whereas in Uzbekistan still by far the most persons are detained on religious grounds, there is a high number of detainees in Kazakhstan and Tajikistan, as well, and only Kyrgyzstan has a significantly low number of around 50 detentions due to religious affiliation.

Table 22: Detainees on Religious Grounds

\begin{tabular}{|l|l|l|l|l|}
\hline & Kazakhstan & Kyrgyzstan & Tajikistan & Uzbekistan \\
\hline $\begin{array}{l}\text { number of per- } \\
\text { sons detained on } \\
\text { religious grounds }\end{array}$ & $300-400$ & 50 & $300-400$ & 7,000 \\
\hline
\end{tabular}

Source: Interview with Ponomarev.

To conclude, I can say that Kazakhstan is the least religious country in Central Asia, and religious policies have only just recently become harsher especially with the re-registration process of 2011/2012. By contrast, Kyrgyzstan's religious policies are most open with regards to religious laws and the acceptance of religious diversity. As for Tajikistan; its laws are farreaching but the country does not seem to be able to fully put them into action. After the peace agreement the IRPT was legalized but its real potential as an Islamist opposition force has been reduced to absurdity by a very tight state control and repression against its members. Uzbekistan has the most 'totalitarian' situation as it is the country with the most restrictive laws and at the same time has the necessary resources to exercise a great deal of control over devout Muslims. 
PART III

SECURITIZATION:

THEORY AND SIMULATION MODEL 



\section{Securitization Theory: Legitimacy in Security Politics}

\subsection{Legitimacy in Securitization Theory}

Directly and in the short term repression against terrorist groups can only diminish their resources - therefore its counter-intended effect can only take place in the long run. Furthermore, the counter-intended effect of repression is only conceivable in connection with the security discourse of the terrorist groups' opponents. In order to understand this counter-intended effect I present securitization theory which deals with the question of how actors develop legitimacy for the imposition of extraordinary means. With my simulation-analysis I am subsequently able to analyze the feedback loops of intended and counter-intended effects of state repression.

\subsubsection{Legitimacy and Audience in Security Politics}

Securitization Theory belongs to the wider branch of Critical Security Studies which itself is a constructivist approach in the studies of International Relations. The theory is built on the assumption that security is not an objective fact. It explains how security is socially constructed by 'securitizing' issues:

"A security issue is posited (by a securitising actor) as a threat to the survival of some referent object (nation, state, the liberal international economic order, the rain forests), which is claimed to have a right to survive. Since a question of survival necessarily involves a point of no return at which it will be too late to act, it is not defensible to leave this issue to normal politics. The securitising actor therefore 
claims a right to break normal rules, for reasons of security" (Buzan \& Waever 2003: 71).

Securitization theory explains how security actors mobilize their audience by leading a security discourse in order to become capable of implementing extraordinary means. With the focus on this approach the hitherto cursory vicious-circle hypothesis is enriched by a constructivist theory specialized in discursive preparation for the implementation of security policies. Securitization theory explains the deployment of extraordinary means in security politics by framing security issues: "The social design of a security problem conditions and legitimates the kind of means used to stop it." (Balzacq 2011: xiii). The theory can be used to study persuasion, legitimization, and social mobilization (Vuori 2011: 186). I use the work of Thierry Balzacq (2011) who developed a sociological approach to securitization theory as a basis, which is more useful to my research purpose than the initial approach of the Copen Hagen School developed by Ole Waever, Barry Buazan and Jaap de Wilde. ${ }^{1}$ In particular, the more clearly defined concept of audience (or even several audiences) by Balzacq speaks for this approach because audiences are crucial for understanding legitimacy. This approach is furthermore more suitable to my cases since it defines practices and performatives (in addition to speech acts) as securitizing acts.

The three core assumptions for understanding the discourse which makes an issue a security issue and thereby justifies the imposition of violent means are (Balzacq 2011: 3):

- Centrality of audience

- Co-dependency of agency and context

- The dispositif and the structuring force of practices

I will go into further details regarding these concepts in the following sections.

1 The Copenhagen School pays only little attention to clearly defining the role of the audience and, for my purpose, treats securitization too exclusively as a speech act. 


\subsubsection{One Theory for Analysing Both Conflict Parties}

As we have seen, Schlichte states that the need for legitimacy is a precondition for state as well as for non-state actors to participate in a conflict. Securitization theory allows us to analyze state as well as non-state actors with the same theoretical framework. This theory can explain whether a group is capable of legitimizing its violent behaviour and to what extent. Vuori, for example, analyzes the impact of securitization for the mobilization and suppression of social movements. But even though he acknowledges that securitization studies traditionally centre on legitimization from the side of the authorities, he also criticizes the fact that protest studies (and social movement theories) capitalize on the mobilization of social movements, and he shows that "both literatures often overlook the interaction between the authorities and protestors: both sides of the struggle may take the other's moves into account" (Vuori 2011: 189). Vuori highlights that the theory of securitization provides a single framework that enables us to explain the behaviour of both (state and non-state) sides involved in a conflict. In my view this is very useful for the sake of complexity-reduction and for an understanding of the vicious circle. In addition, it helps us to better understand the mutual constitution of securitizing actors and audiences.

It is furthermore interesting to use only one framework for state as well as non-state behaviour as it is observable that both sides behave very similarly, namely in an essentialist way: on the one hand, the behaviour of Muslims is solely explained by their religion. Such an essentialist argumentation leads to the negligence of historical and social factors and sees Islam as the only and all explaining essence (Khalid 2007: 5). For these reasons, the securitization of Islam has been analyzed in different settings from Europe (Cesari 2009) to Pakistan (Sheikh 2009). Moreover, Meyer explains that the fundamentalist identity politics of religious groups has the same goal as the apparently reactive western identity politics à la Huntington - both of them use cultural differences as a means of legitimating their power (Meyer 2002: 9). ${ }^{2}$ Therefore, I find it interesting to apply the theory to both sides in the conflict.

2 Authors such as Bernard Lewis (2003), Zbigniew Brzezinski (2004) and Samuel Huntington (2002) are responsible for creating this new dualist narrative and entitle their books Crisis of Islam, The Great Chessboard and Clash of Civiliza- 


\subsection{VOCABULARY AND UNITS OF ANALYSIS}

Securitization theory gives us a theoretical framework for analysing how new security issues evolve, how such threats are framed and who is involved in the securitization process. The main elements (of the sociological approach according to Balzacq) of securitization theory are introduced in the following sections. Following this, securitization theory provides my simulation analysis with a specified vocabulary, the units of analysis and the assumptions about the mechanism of securitization.

\subsubsection{Securitizing Actors}

As has already been mentioned, Vuori underpins the possibility of using the same theory for both sides in the conflict, for state as well as non-state actors (Vuori 2011: 189). As a result, both parties assume the role of securitizing actors. As with state actors so too can non-state actors declare states of exception (Salter 2011: 118). Yet what makes an actor a securitizing actor? Events can have different meanings to different actors. A securitizing actor is one who interprets an event in a securitizing way, which means that he declares the existence of a referent object to be endangered by the securitized issue. By his argument the securitizing actor calls for extraordinary means to stop this danger. If a securitizing actor defines something as an existential threat to some referent object, this is called a securitizing move (see next section).

In my study, securitization theory explains that extraordinary means (here: repressive or radical means) have to be legitimized by every actor and this is done by securitizing a referent object, which is claimed to be endangered by a threatening object. This means:

tions. These authors are essentialists as they explain the behaviour of Muslims solely by their religion. This new dualism therefore has many critics: ,[...] in public discourse and also among academics who had not worked on non-western regions, state failure, new wars, organized crime, and transnational terrorism were meshed together into a legitimizing discourse for a new wave of securitization and militarization“ (Schlichte 2009: 9). Analysts blame the aforementioned authors for essentialism, because they reduce all conflicts to the differences among cultures (Cesari 2009; Khalid 2007: 5; Meyer: 2002; Schlichte 2009). 
- State actors claim that the secular state is threatened by terrorist Islamists who want to establish sharia - therefore they enforce restrictive religious policies and ban religious groups.

- Non-state actors claim that the just Islamic society is threatened by repressive corrupt leaders who constrain religious freedom - and therefore they wage jihad against them.

Referring to the protests in Kyrgyzstan in October 2005, Wilkinson explains how even a single (conflict-)event can be securitized in different ways by different actors:

"The protester's common narrative centred on portraying Kyrgyzstan (the land, rather than the state) and/or its people as being subjected to an existential threat - from corruption, criminalisation, worsening economic conditions - and a demand for immediate action from the government to address the threats. Simultaneously, however, there was a counter-securitizing narrative being presented by other groups (such as the governments of neighboring republics) that portrayed protests themselves as a visible sign of Kyrgyzstan's continued instability and insecurity and therefore as a threat to the republic's existence as a state" (Wilkinson 2011: 104).

In our case the state refers to the nation state as the referent object, nonstate actors on the other hand refer to free religious practice as the referent object. Both securitize Islam (securitizing issue) for their means: state actors say foreign Islamic influences threaten the national security and sovereignty of their countries. Non-state actors see the 'secular' contemporary regimes as threatening the good life of devout Muslims. Both are right from their point of view - therefore a security dilemma exists.

\subsubsection{Securitizing Moves}

The securitization takes place through a securitizing move. A securitizing move refers to a referent object, which is the good that a securitizing actor's ultimate goal is to protect. ${ }^{3}$ The original securitization theory intro-

3 The referent object can for example be the liberal international economic order, the planetary ecosystem, a community or a state (Buzan and Waever 2003: 12). 
duced by Barry Buzan's and Ole Waever's Copenhagen School (CS), focused on securitizing acts as speech acts. Their main idea was that by defining something as a security problem the first step had been taken to implement extraordinary means. Persons with a great deal of influence in society can promote securitizing speech acts. The speeches of politicians and others who have an influence on security politics as well as publications of institutions and scientists are analyzed in this context (see for example Hagmann 2009).

In the understanding of the Copenhagen School a speech act does more than describe reality - it is a means of power and realizes a specific action (Balzacq 2011: 1). Contrary to this view, Balzacq considers that the power of words depends on (2011: 25):

- the context and the power position of the agent that utters them,

- the relative validity of statements for which the acquiescence of the audience is requested; and

- the manner in which the securitizing actor makes the case for an issue, that is, the discursive strategy displayed.

As a result, the sociological approach on securitization of Balzacq and others, "talk about securitization primarily in terms of practices, context, and power relations that characterize the construction of threat images" (Balzacq 2011: 1). This is especially important in a non-democratic setting where the implied assumption that speech acts are desirable and possible is not given because of restrictions on the freedom of expression (Wilkinson 2007: 12). Therefore, Wilkinson (2007), Vuori (2008: 71) and others (Balzacq 2011, McDonalds 2008: 570, Salter 2011) recommend including written sources such as political programs and laws when analysing securitization in an authoritarian setting. In my study I refer to religious laws as written sources of securitization, and undifferentiated repression of the population through restrictions on the practice of religion as securitizing practices by state authorities. Non-state actors exercise a securitizing move with pamphlets, with their own fatwas, and word-of-mouth propaganda at regular group-meetings and in prisons. 


\subsubsection{Audience}

Securitization does not take place by the securitizing move of the securitizing actor alone. The securitizing move, conducted by a securitizing actor, is always addressed to an audience (or to several audiences). ${ }^{4}$ The success of a securitizing move depends on the support it receives among the audience. Whereas CS usually concentrates on successfully securitized cases, there are other authors who study the success or failure of securitization moves. ${ }^{5}$ Securitization only takes place when the securitizing move is accepted by the audience (Léonard \& Kaunert 2011: 58). However, in order to be successful, "securitization does not require the consent (formal or informal) of the entire audience, it only requires the consent of enough of the audience the 'critical mass' that O'Reilly (2008) explains as a combination of volume and quality" (Vultee 2011: 83). Its success is therefore dependent on helping a securitizing actor to "rightly perceive the feelings and needs of the audience [...]", and enables him to use a, "[...] language that will resonate well with the audience" (Léonard and Kaunert 2011: 61; see also Balzacq 2005: 184). For these reasons, in every empirical study on securitization the audience has to be clearly defined.

The audience might usually constitute the citizens in a democratic state or governmental elite - especially in the case of a non-democratic system (Vuori 2008: 72). The support given by an audience can be formal (policymakers such as parliamentarians) or moral (general public) (Léonard and Kaunert 2011: 62). However other audience settings are also possible, such

4 " $[. .$.$] the idea of the 'audience' oversimplifies the fact that there can be multiple$ audiences, with different characteristics" (Léonard \& Kaunert 2011: 60).

5 Salter criticizes the lack of study into the failure of securitization (Salter 2011: 116). But "we cannot accept a simply binary result of 'accepted' or 'failed' securitizing moves $[\ldots]$. Rather, there are several steps in the acceptance or failure of a securitizing move" (Salter 2011: 119). Along with Salter, the question of whether a securitizing move was successful or not can be decided by answering these questions: "To what degree is the issue-area discussed as a part of a wider political debate? Is the description of the threat as existential accepted or rejected? Is the solution to the threat accepted or rejected? Are new or emergency powers accorded to the securitizing agent?” (Salter 2011: 119f). 
as popular, elite, technocratic and scientific settings (Léonard and Kaunert 2011: 62).

In this case I will refer to the whole population of a Central Asian nation state as the audience of the state-actors and to the Muslim population of the state as the audience of the Islamist non-state actors. It is rather uncommon to speak of legitimacy in relation to authoritarian regimes and non-state groups accused of terrorism. Often it is assumed that only liberal democracies need legitimacy to implement extraordinary means because they depend on public opinion to a greater extent than authoritarian regimes. I postulate that even authoritarian regimes depend on the population's participation with what Vuori refers to as the "ritual of conformity" (Vuori 2008: 71). Compared to democracies, where legitimacy is necessary to win the next elections, securitization in these states conduces to maintain the political order, to exercise control over the population and to renew discipline (Vuori 2008: 69). It is worth pointing out, though, that securitization theory can also be used to analyze the legitimacy of authoritarian regimes although it is more often applied to an analysis of western democracies.

The fact that the intention of terrorism per se is to awe people, as well as the fact that the condemnation of foreign groups and alleged terrorists in authoritarian regimes often have the appearance of show trials, serves to demonstrate that, repressive acts, including acts of terrorism are often not only directed at the immediate victims (see definition of terrorism in section 1.1.2) of these acts but also at the general public. Waldmann, an expert on terrorism mentions the "Reaktionsangewiesenheit" of terrorists: on the one hand, terrorists intend to provoke a disproportionate reaction from the government they attack in order to trigger a circle of action and repression that allows the enemy to be "exposed" (2003: 88). The brutal and disproportionate response of security forces should show Islamist sympathizers that the fight against the government is a necessity. On the other hand, the fact that acts of terror can be used to justify brutal police violence could explain why it is so difficult to disprove that acts of terror are not provoked by the government itself (for example 1999 bombings in Tashkent; see Naumkin). Lastly, non-state violence helps authoritarian states to strengthen their power. 


\subsubsection{Preconditions and Context of Securitization}

The securitization act takes place in a certain context: securitizing actors have a certain 'dispositive' to securitize. Furthermore, preconditions such as regulatory and capacity tools influence the success of a securitizing move (Balzacq 2011: 17ff). Regulatory tools are policy instruments such as written programs, laws etc. Capacity tools contain material and nonmaterial resources such as information, training and so on. In our case, the religious ministries, the Muftiate and security forces represent the state's capacities. Non-state actors rely in this regard mainly on their members and support by foundations and allies.

Apart from these preconditions of the security move, the context of the securitization is important for its analysis. Two different kinds of context are embraced in the analysis of securitization: proximate and distal context. Whereas the proximate context outlines the questions of who securitizes what and when (Wilkinson 2011: 107f), the distal context describes how and why securitization takes place (Wilkinson 2011: 108ff). According to Salter, the "proximate context refers to the immediate features of interaction", to the stage on which and the genre in which a securitizing move is made as well as to the audience and its reception of the securitizing move (Salter 2008: 328). I have already mentioned the importance of the mutual incitement of opponents, which can be included as part of the proximate context in the analysis (Vuori 2011: 189). Whereas Wilkinson describes the proximate context as the micro-environment, he refers to the distal context as the macro-environment of the securitization, where "social class and ethnicity, regional and cultural settings, and the sites of discourse" matter (2011: 98). The political system in which securitization takes place is also part of the distal context. It therefore allows us to take into account the special circumstances of authoritarian regimes and socio-demographic preconditions for conflicts. In our case, the distal context for the securitization of Islam is represented by the context-legitimacy (good governance and socioeconomic situation) of the Central Asian states as well and by the revival of Islam in the region. 


\subsection{Securitization of Islam in Central Asia}

\subsubsection{Units of Analysis in the Central Asian Context}

Securitization theory explains that the securitization of an issue takes place when a reference object is presented as threatened in a securitizing move. With regards to my research question I suppose that a vicious circle develops because a securitizing move on one side also results in the securitization of the opposing side. This means: violence by one party justifies the opposing party's perpetuation of the violence. The more repressive the state is against ordinary devout Muslims the easier it is for Islamists and jihadists to present the state as threatening the right to freedom of religion. However, the more acts of violence by non-state actors occur the easier it is for the government to justify its rigorous policies against all 'foreign' Islamic groups.

Table 23: Securitization Theory in the Central Asian Context

\begin{tabular}{|l|l|l|}
\hline & State Actor & Non-State Actor \\
\hline $\begin{array}{l}\text { Reference } \\
\text { object }\end{array}$ & $\begin{array}{l}\text { Positive: secure governmental } \\
\text { power } \\
\text { Negative: freedom from sharia }\end{array}$ & $\begin{array}{l}\text { Positive: sharia, Islamic } \\
\text { society/state } \\
\text { Negative: freedom from } \\
\text { corrupt leaders }\end{array}$ \\
\hline $\begin{array}{l}\text { Securitizing } \\
\text { move }\end{array}$ & $\begin{array}{l}\text { Speech act: restrictive laws, } \\
\text { fatwas (issued by the Muftiate) } \\
\text { Practice: repression of the free } \\
\text { practice of religion }\end{array}$ & $\begin{array}{l}\text { Speech act: fatwas, other } \\
\text { publications (leaflets etc) } \\
\text { rel. instruction } \\
\text { Practice: jihad }\end{array}$ \\
\hline Dispositive & $\begin{array}{l}\text { Regulatory tools: institutions } \\
\text { (ministry, muftiate) } \\
\text { Capacity tools: security forces, } \\
\text { alliances }\end{array}$ & $\begin{array}{l}\text { Regulatory \& Capacity tools: } \\
\text { members }\end{array}$ \\
\hline Audience & Citizens & Religious ummah \\
\hline
\end{tabular}


The following causal loop diagram displays these conflict assumptions and the vicious-circle hypothesis graphically.

\subsubsection{Vicious-Circle Hypothesis as a Causal Loop Diagram}

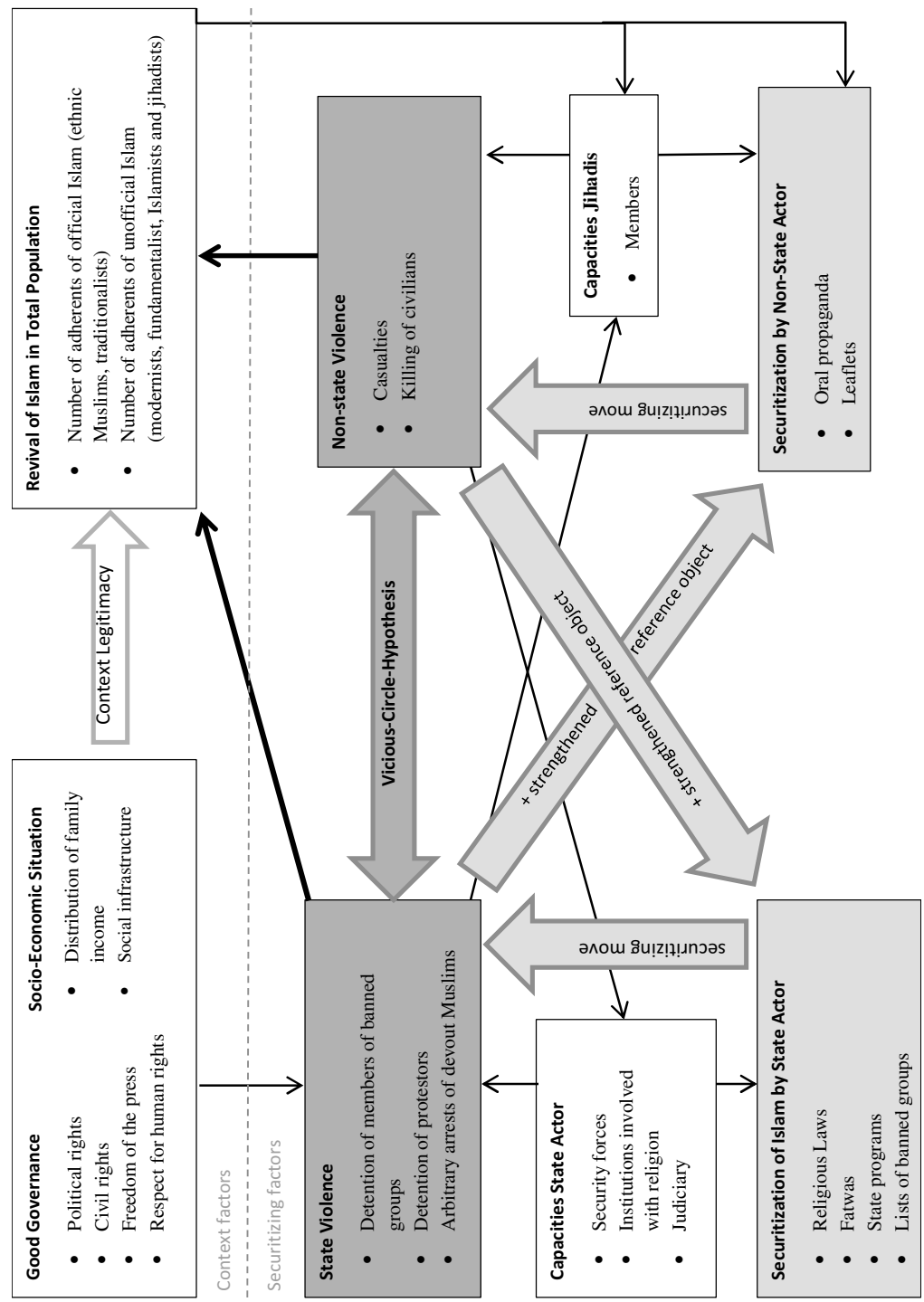


According to the causal loop diagram above, the following conflict assumptions elaborate on the hypothesis of the vicious circle of securitization of Islam in Central Asia:

Table 24: Conflict Assumptions for Vicious Circle Hypothesis

\begin{tabular}{|c|c|}
\hline & $\begin{array}{l}\text { Vicious-Circle Hypothesis } \\
\text { Expected correlation of repression and radicalization on the macro } \\
\text { level by the Vicious-Circle Hypothesis. This correlation is not directly } \\
\text { analyzed - securitization theory explains how the correlation comes } \\
\text { about. }\end{array}$ \\
\hline & $\begin{array}{l}\text { Conflict Assumptions from Securitization Theory } \\
\text { State Actor } \\
\text { - Goal: detention of terrorists and prevention of acts of terrorism. } \\
\text { - Intended effect (securitizing move): the aim of state violence (de- } \\
\text { tention of alleged extremists and terrorists) is to prevent the } \\
\text { spread of 'foreign' Islamic groups in the country. } \\
\text { Non-State Actor } \\
\text { - Goal: non-state violence is aimed at the physical or psychological } \\
\text { weakening of security forces, the terrorization of civilians or ma- } \\
\text { terial damage. } \\
\text { Intended effect (securitizing move): to show the strength of the } \\
\text { movement and probably gain new sympathizers as well as pro- } \\
\text { voke a disproportionate response from the state. }\end{array}$ \\
\hline & $\begin{array}{l}\text { Counter-Intended Effects (strengthening of reference object) } \\
\text { State Actor: violations of human rights might aggrieve people. Al- } \\
\text { leged 'extremist' and 'terrorist' detainees are especially prone to mis- } \\
\text { treatment in prisons - this fact as well as the conditions in the specific } \\
\text { prison systems can lead to the radicalization of individuals. } \\
\text { Non-State Actor: }{ }^{6} \text { terrorist attacks alienate the population and con- } \\
\text { vince them that political Islam is not a humane alternative to the ex- } \\
\text { isting regimes. Furthermore, they strengthen the acceptance of restric- } \\
\text { tive state policies against non-official religious groups. }\end{array}$ \\
\hline
\end{tabular}

6 In the computer simulation I am interested in the counter-intended effects of state violence only. The counter-intended effect of non-state actors is not elaborated on in the computer simulation in order not to make the model too complex. 


\begin{tabular}{|l|l|}
\hline & $\begin{array}{l}\text { Context-Lecitimacy } \\
\text { According to theories introduced in section } 1.2 \text { diverse factors (sub- } \\
\text { sumed here as context-legitimacy) have had an impact on the revival } \\
\text { of Islam (in Table } 28 \text { the measure of context-legitimacy is explained) }\end{array}$ \\
\hline$\rightarrow$ & $\begin{array}{l}\text { Minor Influences } \\
\text { (explained from top to bottom and left to right): } \\
\text { - Human rights abuses impact state violence } \\
\text { - State violence is caused by state institutions (security forces and } \\
\text { religious institutions) } \\
\text { - These state institutions influence the securitization of non-state } \\
\text { actors } \\
\text { State violence has a direct effect on the jihadists' capacities } \\
\text { Non-state violence has a direct effect on the state's capacities } \\
\text { The revival of Islam has an impact on the strength of jihadists and } \\
\text { on the extent to which the secular state is securitized }\end{array}$ \\
\hline
\end{tabular}

In the next chapter I will translate these theoretical conflict assumptions as well as my conclusions from the case studies (see typologies in chapter 4 and chapter 9) into a simulation model. It will be interesting to find out if these very simple conflict assumptions allow us to forecast some important conflict features. It is generally accepted that models should be as simple as possible and as complex as necessary to have a maximum explanatory power. For the moment, therefore, I do not take into account interesting factors such as the internal organizational structure of religious groups or more elaborate assumptions on the composition of groups' demographic features. Instead, I concentrate on those aspects which are said to play an important role according to securitization theory and according to the findings of my case studies. 



\section{Model Description}

I begin by showing how securitization theory can be translated into a conflict model. I then give an overview of our model with the standardized ODD-Protocol (Railsback and Grimm 2012: 37ff). This is an important tool for agent-based modellers to describe their models and to make them replicable - an important feature of any scientific work. In equation-based simulations, the equation explains exactly what is being simulated. However, as the ABM technique is rather a system of procedures than of equations, the ODD-Protocol helps us to understand what is being simulated. However, the ODD-Protocol is only thoroughly understood by scientists familiar with ABM-studies and not very reader-friendly. Therefore, the subsequent sections describe the step-by-step implementation of the theoretical assumption into the simulation model and provide some brief background information on ABM in general.

\subsection{OVERVIEW AND ODD-PROTOCOL}

\subsubsection{Different Interpretations of One Event}

As was demonstrated in the last chapter, the behaviour of state as well as non-state actors can be conceived of as securitization. In fact, they show different securitizing moves, but I concentrate here on one of the most important ones: the government arrests individuals who adhere to an unofficial interpretation of Islam while sympathizers of such groups either protest peacefully against or physically attack the government. I here focus on how the detention of Muslims is interpreted differently by governments and in- 
dividuals respectively. I define 'arbitrary arrest' in the simulation as follows: an individual who is not a jihadist and who has not protested is arrested because he is a sympathizer of unofficial Islam.

As we are concerned with conflict-behaviour it is important to note that the securitizing move by governments is assumed to be a centralized strategic decision that is taken according to the 'global' situation, and which is executed by all security forces acting in the same way: they start to arrest sympathizers of unofficial groups arbitrarily if they fear that unofficial Islam has become too widespread. The securitizing behaviour of citizens (or non-state actors) on the other hand is based on local information about arrests: there is no strategic group-behaviour by non-state groups led by decision-makers but rather (because of the assumption that radicalization takes place individually rather than on a group level) the agents individually decide to protest against the arbitrary arrests they have observed in their immediate neighbourhood.

Table 25: Securitization in the Simulation

\begin{tabular}{|c|c|c|}
\hline & Government/ State Actor & Citizens/ Non-State Actor \\
\hline $\begin{array}{l}\text { Reference } \\
\text { object }\end{array}$ & Freedom from terrorist acts & $\begin{array}{l}\text { Freedom from religiously } \\
\text { motivated arrests }\end{array}$ \\
\hline $\begin{array}{l}\text { Securitizing } \\
\text { move }\end{array}$ & $\begin{array}{ll}\text { - } & \text { Outlawing of groups } \\
\text { - } & \text { Arrests of group members }\end{array}$ & $\begin{array}{ll}\text { - } & \text { Protest against arrests } \\
\text { - } & \text { Attacks against security }\end{array}$ \\
\hline Dispositive & $\begin{array}{l}\text { - } \\
\text { - }\end{array}$ & $\begin{array}{ll}\text { - } & \text { For protests: sympathizers } \\
\text { of unofficial Islam } \\
\text { - } & \text { For attacks: jihadists }\end{array}$ \\
\hline
\end{tabular}




\subsubsection{ODD-Protocol}

I rely here on the concept of the ODD-Protocol described in Railsback and Grimm (2012).

\section{Table 26: ODD-Protocol}

\section{Purpose \\ The model represents how a vicious circle of the securitization of Islam by state and non-state agents develops. From this I want learn how state repression and Is- lamic radicalization reinforce each other. In particular, I hope to demonstrate how arrests of alleged terrorists can be interpreted in two different ways: on the one hand they help to maintain national security and state power but on the other they threaten human security and human rights because arbitrary arrests occur and de- vout sympathizers of unofficial Islamic groups are arrested as alleged 'terrorists'. Goals of the Model: \\ It is the goal of this study to find out how the reinforcement of mutual securitiza- tion works in theory and whether it brings about a vicious circle of conflict. \\ Furthermore, I want to ascertain whether the securitization of Islam by Central Asian governments explains the radicalization of Islamists in Kazakhstan, Kyr- gyzstan, Tajikistan and Uzbekistan}

\section{Entities, state variables, and scales}

2. Entities, state variables, and scales

\section{Entities}

Two types of agents:

State agents:

- Security forces

Non-state agents/ citizens

- Non-Muslims

- Adherents of official Islam (ethnic Muslims and traditionalists)

- Adherents of unofficial Islam (undesirable and banned groups such as Sufis, modernists (corresponds to Nurcilar), fundamentalists (corresponds to Tablighi Jama'at), Islamists (corresponds to IRPT, HT), jihadists (corresponds to IMU and IJU) 
Behavioural Strategies:

- Security forces aim to eliminate jihadists by means of justified arrests; furthermore they want to deter other citizens from becoming sympathizers of unofficial Islam by arresting them arbitrarily.

- Jihadists: aim to eliminate security forces by attacking them directly; furthermore they try to provoke a disproportionate response from the security forces by attacking citizens (in order to galvanize their co-citizens)

- Objective of all citizens: Maximum religious freedom (absence of religiously motivated arrests) and maximum physical security (absence of attacks)

Attributes

State agents own:

- Range (of security forces) (estimation; value: radius of 1.2 grid cells)

- Context-legitimacy (describes the legitimacy a state derives from contextual factors such as its good governance and socio-economic situation) (based on empirical data; range: 0 - 10, lower means less legitimacy)

- Political Terror Scale (PTS); describes the extent of human rights abuses by the state) (based on the empirical data presented in Table 19: 1-5, lower means fewer human rights abuses)

Citizens' own:

- Neighbourhood (estimation; value: radius of one grid cell)

- Detention-time: different for detained 'terrorists' and for protestors) (estimation; range: 40 - 180 time steps, 40 for detained protestors, 180 for detained 'terrorists')

- Arrested (counts how many times an agent was arrested)

- Participated-in-protest (counts how many times an agent participated in a protest)

- Protest-time (describes how long an agent participates in a protest)

- Prison-term (describes how long an agent has been in prison)

- Hit (describes if an agent is hit by a terrorist attack)

- Religiosity (describes how easily the population is proselytized; range: $1 / 1,000-1 / 100)$

Temporal and spacial scale:

300 time steps (ticks) are simulated. I assume that one tick is one month or 12 ticks are one year, respectively. (As it is the goal to simulate the time since the independence of the Central Asian states up until today, this means I simulate 25 years.) 
The model is spacially explicit (but not geo-referenced): the agents meet in a simulated world in order to exchange information and influence each other. Security forces have global information and local ability to act and citizens have local information as well as a local cruising radius.

\section{Process overview and scheduling}

Within each time step, the following processes are run, in the given order, by the agents referred to in parentheses. Agents perform their tasks in a randomized order; state variables are updated immediately.

Processes

- Move (all agents): all agents move randomly (if they are not arrested or protesting)

- Proselytize (sympathizers of unofficial Islam): proselytize ethnic Muslims to become a sympathizer of their own group (the lower the context-legitimacy of the state, the easier it is to proselytize them)

- Arrest and arrest-protestors (security forces): searches and arrests jihadists and protestors as well as arrests sympathizers of unofficial Islam (if their number is more than $0.1 \%$ of the total population) for prison-term

- Protest (sympathizers of unofficial Islam): they protest if they witness the detention of an agent of his own group during protest-time

- Attack (jihadists): jihadists look for opportunities to attack security forces; if they are next to a member of the security personnel they have such an opportunity - all immediate neighbours are hit

- Radicalize (sympathizers of unofficial Islam): peaceful individuals who are arrested arbitrarily as well as protestors who are arrested because they occasionally participated in a protest are radicalized in prison and become jihadists when released (the more they are exposed to human rights violations in prison the more prone they are to radicalization (one in ten detainees would be radicalized if no human rights abuses occurred. The political terror scale is used as a multiplying factor for this assumption (the higher PTS, the more probable the radicalization: $0.1-1.0$ ). 


\begin{tabular}{|c|c|}
\hline \multicolumn{2}{|c|}{ 4. Design Concepts } \\
\hline $\begin{array}{l}\text { 4a) Basic } \\
\text { principles }\end{array}$ & $\begin{array}{l}\text { Concepts, Theories and Hypotheses: } \\
\text { The processes in the model implement findings from our case } \\
\text { studies and theoretical considerations from securitization theo- } \\
\text { ry. } \\
\text { - Case studies: the general revival of Islam is illustrated with } \\
\text { the Proselytize procedure; the Attack procedure describes } \\
\text { acts of terrorism; the banning of Islamic groups and the } \\
\text { persecution of their sympathizers is illustrated with the Ar- } \\
\text { rest procedure } \\
\text { Securitization theory: the theory explains how Proselytize } \\
\text { and Arrest procedures justify the behaviour of the opponent } \\
\text { and thereby fan the flames of the vicious conflict circle } \\
\text { CLD (see section 10.3.2) shows the conflict assumptions } \\
\text { with the corresponding influences and feedback loops (in- } \\
\text { tegration of case studies and securitization theory) }\end{array}$ \\
\hline 4b) Emergence & $\begin{array}{l}\text { Results and Outputs: } \\
\text { The model is meant to represent the first step in the revival of } \\
\text { Islam. Following this, the mutual escalation of securitization } \\
\text { and violence by state and non-state actors should emerge. }\end{array}$ \\
\hline 4c) Adaptation & The model does not include adaptations. \\
\hline 4d) Objectives & No \\
\hline 4e) Learning & No \\
\hline 4f) Prediction & No \\
\hline 4g) Sensing & $\begin{array}{l}\text { Citizens are fully informed of the attributes of their neigh- } \\
\text { bours. Security forces have global knowledge of all other } \\
\text { agents. }\end{array}$ \\
\hline 4h) Interaction & $\begin{array}{l}\text { Interaction among neighbour agents (within the radius of one } \\
\text { grid cell) is direct; they proselytize, attack or arrest each other. } \\
\text { These assumptions for the simulated interaction refer to real at- } \\
\text { tempts at proselytization by groups who have a social utopian }\end{array}$ \\
\hline
\end{tabular}




\begin{tabular}{|c|c|}
\hline & $\begin{array}{l}\text { ideology, real attempts to attack security forces, the arrest and } \\
\text { detainment of members of Islamic groups; efforts by Islamists } \\
\text { to recruit among inmates in prison; the social power of dis- } \\
\text { missed detainees as martyrs. }\end{array}$ \\
\hline 4i) Stochasticity & $\begin{array}{l}\text { In order not to make the model totally deterministic, one can } \\
\text { mimic randomness and NetLogo has a built-in procedure for } \\
\text { such pseudo-randomness. }{ }^{1} \text { The distribution of the agents on the } \\
\text { grid when setting up the agents during the initialization is } \\
\text { pseudo-random. The direction of the movement of the agents is } \\
\text { also pseudo-random (the distance they cover is one grid cell). } \\
\text { The probability for the radicalization of an agent is randomized } \\
\text { as well. }\end{array}$ \\
\hline 4j) Collectives & See agent-types in (2. Entities, state variables, and scales) \\
\hline 4k) Observation & $\begin{array}{l}\text { Graphs depict: } \\
\text { - The development of the numbers of sympathizers of Islam- } \\
\text { ic groups: the ratio of the number of jihadists vs. the num- } \\
\text { ber of adherents of unofficial Islam } \\
\text { - The number of attacks and the number of arbitrary arrests } \\
\text { With these graphs I will be able to find out: } \\
\text { - If an escalation of arbitrary arrests (of peaceful Muslims) } \\
\text { leads to an increase in attacks (or whether state repression } \\
\text { leads to the radicalization of Islamists) } \\
\text { Furthermore, I observe at what point in time the security forces } \\
\text { start to arbitrarily arrest sympathizers of unofficial Islam } \\
\text { (which means that they start to securitize their behaviour). }\end{array}$ \\
\hline
\end{tabular}

1 „NetLogo uses a pseudorandom number generator to output a sequence of statistically random numbers which is then used to determine the order of agents called or whenever the appearance of non-determinism is needed." See http:// serendip.brynmawr.edu/exchange/parallelp (13.9.2014). 


\section{Initialization}

Two initializations for every case:

The initial situation represents the religious situation of the Central Asian states in the early 1990s.

Same conditions for every case:

- 5,000 citizens

Changing conditions depending on case:

- Context-legitimacy of the government

- Proportion of ethnic Muslims in population

- General religiosity of the society

- Number, range and cruelty (PTS) of security forces

- Capacities of security forces (human and financial resources)

Exact data for each case are presented in Appendix D.

\section{Input data}

Empirical input data from the following sources are used in the simulation (see section 11.2.2 and Appendix C):

- Security forces capacities (personnel and military expenditures) (Military Balance)

- $\quad$ Political Terror Scale (PTS)

- Context-legitimacy of government (empirical index, see Table 28)

- Percentage of ethnic Muslims (empirical data, CIA World Factbook)

\section{Submodels}

See NetLogo Code in Appendix B.

\subsection{Simulation Setup}

I work with NetLogo (Wilensky 2013) here, a simulation program especially useful for ABMs (it can be used for System Dynamics, as well, though). This program is often used by social scientists, which makes this study better replicable than if I used a less well-known program. Furthermore, the program is well understood because of its many users. 


\subsubsection{Agent Types}

I distinguish between the terms 'agent' and 'actor'. When we speak of agent-based modelling we understand agents as "self-contained programs that can control their own actions based on their perceptions of their operating environment" (Gilbert \& Troitzsch 2005: 172). Whereas an actor is an individual or a group in the real world, the term agent refers to the simulated individual or group in the computer model. As a matter of fact, there is a direct correspondence between agents and actors, which makes it easy to design the model and understand its outcome (Gilbert 2008: 14). Agents can represent single individuals as opposed to organizations and institutions or bodies such as nation-states (Gilbert 2009: 5). However, the simulated agents are always representations of the real-world actors and conclusions derived from the simulation therefore have to be carefully interpreted and one-to-one comparisons to the real world should either not be drawn or done so with caution.

In the present study individual people are simulated as agents. They exhibit features which allow them to belong to a group. The groups (security forces, official and unofficial Islam) are made up of the individuals sympathizing with them - they support the groups' goals and implement their tactics. When running the simulation, it is possible to analyze the conflict at the macro-level but one can also track the development of the groups separately at the meso-level or the behaviour of a single agent at the microlevel. The main objective of the simulation is to understand how the securitization framing by groups influences the micro-behaviour and in doing so fuels the conflict at the macro-level.

It is common that agents in ABMs have the following features at their disposal (Gilbert 2009: 21f):

- Memory

- Perception

- Performance (motion, communication, action)

- Policy (agent-rules)

In our study the agents remember what they have experienced, for example when they were either arrested or participated in a protest: they have a memory. The agents have perceptions concerning their environment and 
what happens around them. This means they behave according to their memory, perceptions and also according to their groups' features. The agents move and interact (they proselytize, mobilize for protest, attack or arrest each other). The following agent-types are regarded as essential to simulate the revival and securitization of Islam in Central Asia. (They are called 'breed' in NetLogo language.)

- Non-state actors: Citizens are represented as 'ethnic Muslims' or nonMuslims. All of them are interested in living in a peaceful and free environment. Those who are devout and belong to a particular group (as defined in chapter 4: Sufis, modernists, quietist salafis or political salafis) are grouped together as sympathizers of unofficial Islam (there is no 'membership' and no such 'group'). They proselytize their cocitizens and have a special interest in the maintaining the freedom of religion. The term 'sympathizers of official Islam' summarizes individuals who are not religious but 'ethnic Muslims' and desirable devout Muslims who follow the official-traditional interpretation of Islam (here called 'traditionalists'). Furthermore, there are jihadists who fight against the government because they want to establish a caliphate with violent means; whereas the main goal of devout Muslims is to proselytize and to show their solidarity with detained sympathizers of unofficial Islam, the main task of jihadists is to attack security forces.

- State actor: The government (state actor) is represented in the simulation by the security forces and their specific capacities. Their task is to maintain law and order which they can do more successfully if they have sufficient resources.

\subsubsection{Initial Values and Data for Validation}

I base my simulation model on empirical data as well as on estimated initial values and parameters and validate the simulation results with additional empirical data. I thereby rely on the following data: 
Table 27: Application of Data for Simulation Model

\begin{tabular}{|c|c|c|}
\hline & State Violence & Non-State Violence \\
\hline $\begin{array}{l}\text { Empirical input } \\
\text { data used for } \\
\text { the simulation }\end{array}$ & $\begin{array}{l}\text { Security forces capacities } \\
\text { (personnel and military } \\
\text { expenditures) (Military } \\
\text { Balance) } \\
\text { - } \quad \text { Political Terror Scale } \\
\text { (PTS) }\end{array}$ & $\begin{array}{l}\text { - Context-legitimacy of } \\
\text { government (empirical } \\
\text { index, see section 11.3.2) } \\
\text { - Percentage of ethnic } \\
\text { Muslims (empirical data, } \\
\text { CIA World Factbook) }\end{array}$ \\
\hline $\begin{array}{l}\text { Simulation pa- } \\
\text { rameters de- } \\
\text { termined by the } \\
\text { author }\end{array}$ & $\begin{array}{l}\text { - 'Reach' of security forces } \\
\text { (estimation, same for all } \\
\text { cases) } \\
\text { Average arrest-time for } \\
\text { alleged terrorists and } \\
\text { protestors (estimation, } \\
\text { same for all cases) }\end{array}$ & $\begin{array}{l}\text { Religiosity of the society } \\
\text { (estimation based on } \\
\text { ARDA reports) }\end{array}$ \\
\hline $\begin{array}{l}\text { Simulation re- } \\
\text { sults }\end{array}$ & - Arbitrary arrests & $\begin{array}{l}\text { - } \\
\text { - Number of attacks } \\
\text { peaceful protestors who } \\
\text { become jihadists }\end{array}$ \\
\hline $\begin{array}{l}\text { Empirical data } \\
\text { used for the } \\
\text { validation of } \\
\text { the simulation } \\
\text { results }\end{array}$ & $\begin{array}{l}\text { Religious persecution in- } \\
\text { dex (ARDA) } \\
\text { Estimation of detainees } \\
\text { on religious grounds } \\
\text { (interview with } \\
\text { Ponomarev, Memorial) }\end{array}$ & - $\quad$ Suicide attacks (GTD) \\
\hline
\end{tabular}

The context-legitimacy-parameter is used for simulating the promptness of the revival of Islam in the specific cases. I have developed a contextlegitimacy-parameter which is composed of Gini-Index, HDI, Democracy Index, as well as of a ranking concerning freedom of the press (for more information on these measures see chapter 6). This empirically based parameter is composed of the following rankings and indices which were streched 
and/or rounded to a scale ranging from 0 to 10 , where lower means less legitimacy:

Table 28: Calculation of Context-Legitimacy

\begin{tabular}{|l|l|l|l|l|}
\hline & Kazakhstan & Kyrgyzstan & Tajikistan & Uzbekistan \\
\hline $\begin{array}{l}\text { GINI Family } \\
\text { income (index) }\end{array}$ & 7 & 7 & 7 & 6 \\
\hline HDI (index) & 7 & 6 & 6 & 7 \\
\hline $\begin{array}{l}\text { political rights und } \\
\text { civil liberties (index) }\end{array}$ & 2 & 3 & 1 & 0 \\
\hline $\begin{array}{l}\text { Freedom of the } \\
\text { press (ranking) }\end{array}$ & 1 & 4 & 3 & 1 \\
\hline Subtotal & 17 & 20 & 17 & 14 \\
\hline Context-legitimacy & $\mathbf{4 . 2 5}$ & $\mathbf{5 . 0 0}$ & $\mathbf{4 . 2 5}$ & $\mathbf{3 . 5}$ \\
\hline
\end{tabular}

In the next table the initial values (calculated for a total population of $5,000)$ for the simulation of the four cases are presented. For an overview of all initial values and parameters used for the representation of all cases see Appendix $C$.

Table 29: Initial Values for Simulation

\begin{tabular}{|l|l|l|l|l|}
\hline & Kazakhstan & Kyrgyzstan & Tajikistan & Uzbekistan \\
\hline Security forces & 22.5 & 17 & 10 & 15 \\
\hline Non-Muslims & 1,500 & 1,250 & 300 & 350 \\
\hline Ethnic-Muslims & 3,500 & 3,750 & 4,700 & 4,650 \\
\hline Religiosity of society & $1 / 1,000$ & $1 / 1,000$ & $1 / 100$ & $1 / 100$ \\
\hline Jihadists & 1 & 1 & 1 & 1 \\
\hline
\end{tabular}




\subsubsection{Interactions}

When agents interact, they can communicate and subsequently act on the basis of what they learn from these messages (Gilbert 2009: 5). Messages can represent spoken dialogue, pure information flow or the monitoring of other agents. Information "is collected and processed at the agent level and transmitted through interaction structures that are endogenous" (Epstein 2006: 17). In the present study, the information agents receive through interactions with other agents and by monitoring other agents influences their attitude. Depending on the messages they get from others, and on their present condition, they begin (or cease) their participation in the conflict.

Table 30: Interactions of Agents

\begin{tabular}{|c|c|c|c|}
\hline $\begin{array}{l}\text { Icon in } \\
\text { simulation }\end{array}$ & Acting Agent & $\begin{array}{l}\text { Adaptive Agent/ } \\
\text { Condition }\end{array}$ & Procedure Name \\
\hline & $\begin{array}{l}\text { sympathizers of } \\
\text { unofficial Islam }\end{array}$ & ethnic Muslims & proselytize \\
\hline & $\begin{array}{l}\text { sympathizers of } \\
\text { unofficial Islam }\end{array}$ & $\begin{array}{l}\text { arrest of other } \\
\text { sympathizers of } \\
\text { unofficial Islam in } \\
\text { neighbourhood }\end{array}$ & protest \\
\hline & jihadists & security forces & attack \\
\hline & security forces & $\begin{array}{l}\text { jihadists, protes- } \\
\text { tors }\end{array}$ & $\begin{array}{l}\text { arrest } \\
\text { arrest-protestors }\end{array}$ \\
\hline & security forces & $\begin{array}{l}\text { sympathizers of } \\
\text { unofficial Islam, } \\
\text { if > than } 0.1 \% \text { of } \\
\text { total population }\end{array}$ & arrest \\
\hline
\end{tabular}




\subsubsection{Space and Movement}

As in the social world, agents come into contact with their fellow citizens. Therefore, all agents (independently of their 'breed') move in a random way on the grid (which contains $71 \times 71$ 'patches' and 'wraps' horizontally and vertically). This holds true except for those who have been detained or are protesting - they stand still.

The simulated environment is a very abstract representation of the actual physical or ideological landscape of a state. Agents are randomly set up in this graphic world, and they meet randomly. Although it would be not be difficult to let agents of one group stay closer together than to other groups I consider it important in our specific case to let them mix because none of these groups are totally isolated from one another. Those groups who do not have a social utopian ideology consist of ethnic Muslims and traditionalists while those with this ideology aim at proselytizing the others - for these reasons they do not seal themselves off to a high degree either.

\subsubsection{Time}

Computer simulations are categorized according to how they deal with time. In system dynamics, time is represented continuously because the models are based on differential equations. The trajectories of the outcome can be calculated on the basis of the equations. At each time step a change in the model is realized and implemented numerically.

In event based models, on the other hand, changes in the model state are initiated by events, not by regular time steps. Agent based simulations are a special case of discrete time models because they are not based on underlying equations. Instead, the model is represented directly and has an internal state produced by agent rules. I use discrete time steps for running the simulation. At each time step, the agents recalculate their states. Therefore one assumes that the agents' states are updated discretely at every time step, and therefore are synchronous. This, however, is often not the case, because a personal computer has a very limited computing power. Instead, the agents can be activated either randomly or in a sequential order (agent 
$\mathrm{A}$, agent $\mathrm{B}$, agent $\mathrm{C}$ etc). ${ }^{2}$ In our simulation the agents are selected randomly and the simulation works quasi-continuously.

\subsection{Simulation Results: ReVival of IsLAM}

\subsubsection{Unofficial Groups Proselytize}

A general trend in the religious development of the Central Asian countries is that their populations are becoming more devout. In our opinion, the phenomenon of the 'securitization of Islam' can only be understood against this background. I assume here that devout sympathizers of official and unofficial Islam compete with each other to convert their fellow citizens.

Figure 13: Different Religious Groups Compete for Influence

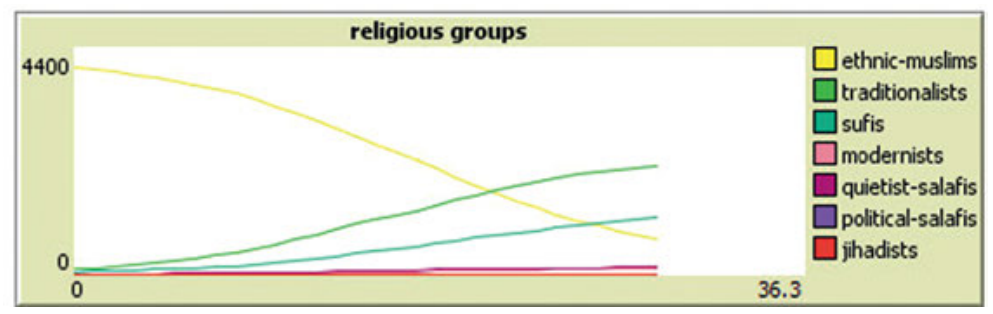

Comment: all groups of devout Muslims proselytize ethnic-Muslims (displayed in yellow in the picture above). As a result, these groups grow at the expense of the number of ethnic Muslims. In Figure 13 the revival of Islam is depicted as a competition between diverse (official and unofficial) devout groups to proselytize ethnic Muslims. However, I have learnt that for the sake of simplicity it is better to group together all unofficial groups under the umbrella term 'unofficial Islam' as the simulation would otherwise become too complex and its explanatory power would be diminished.

2 Another possibility is to simulate a synchronous execution by selecting them randomly, but executing their new state only in the next time step (Gilbert 2009: 28ff). 
As a consequence, I work with the very simple assumption that unofficial Islam is gaining more and more members (due to the proselytizing efforts of the diverse groups summarized under this term), as is exemplified in the following graph:

Figure 14: Unofficial Islam Supercedes Official Islam

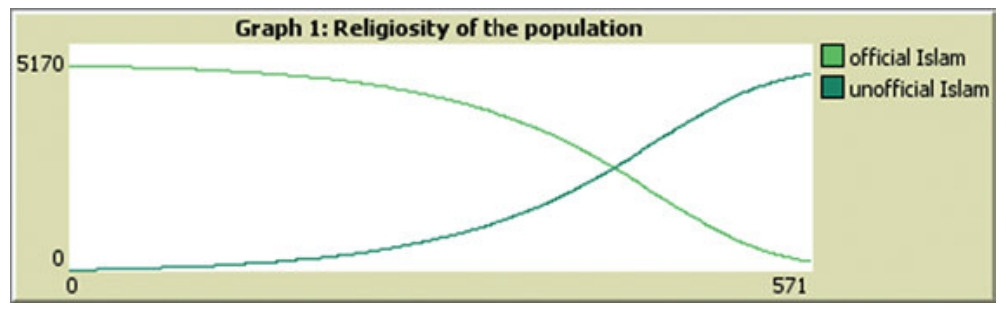

I interpret this to mean that official Islam (numbers of ethnic Muslims and traditionalists) is losing sympathizers to the unofficial proselytizing groups.

\subsubsection{Influence of Context-Legitimacy on Revival of Islam}

It is easier for devout Muslims to proselytize their co-citizens if the overall legitimacy of the state is low. As we have seen in section1.2, and as has been shown by many scientists, a poor economic-situation, the lack of opportunities for political participation combined with high levels of inequality have helped foster the dissemination of radical Islamic thought. The parameter for context-legitimacy presented in the next table ( and introduced in Table 28) has an effect on the speed of the revival of Islam.

Table 31: Context-Legitimacy (Simulation Parameter)

\begin{tabular}{|l|l|l|l|l|}
\hline & Kazakhstan & Kyrgyzstan & Tajikistan & Uzbekistan \\
\hline $\begin{array}{l}\text { Context- } \\
\text { legitimacy }\end{array}$ & 4.25 & 5.00 & 4.25 & 3.5 \\
\hline
\end{tabular}




\subsection{Threatened Reference Objects}

As has already been demonstrated, state and non-state actors refer to different objects in the conflict. The primary implication for the simulation is that proselytizing and the arrest of alleged terrorists are interpreted differently. We now present how state and non-state actors regard their reference object as threatened - a prerequisite to start their securitizting behaviour.

\subsubsection{Maintaining Law and Order: Arrests}

The government fears not only the danger of terrorist attacks toppling the regime but also the prospect of political Islam gaining a critical majority. It is therefore the main task of the security forces to maintain 'law and order' in each respective country. Jihadists who want to establish an Islamic caliphate by attacking security forces as well as individuals solidarizing with (or protesting for) them are arrested (the latter for abetment). A terrorist attack in the simulation represents a suicide attack. Solidarity with arrested agents is represented as 'peaceful protest'.

The capacity of each state's respective security force to arrest citizens depends on their resources (personnel and financial resources). In the simulation the security forces' capacities are assessed by multiplying the number of military and police personnel by the per capita military expenditure of the state. As we see, the countries' security capacities are very diverse: The relevant parameters for simulation are presented in the next table.

Table 32: Capacities of Security Forces (Simulation Parameter)

\begin{tabular}{|l|l|l|l|l|}
\hline & Kazakhstan & Kyrgyzstan & Tajikistan & Uzbekistan \\
\hline $\begin{array}{l}\text { Capacities of } \\
\text { Security forces }\end{array}$ & 35 & 11 & 4 & 19 \\
\hline
\end{tabular}

3 Corresponds to the number of security personnel (Military Balance 2012) per 5,000 population, multiplied by the per capita military spending (Military Balance 2012) and divided by 100 . 


\subsubsection{Protecting Freedom of Religion: Peaceful Protests Against Arrests}

Devout Muslims have the human right to worship. Agents identify with similar agents in their direct neighbourhood and share information with them. Because their reference object (freedom of religion) is threatened, if individuals of the unofficial Islamic groups discover that one of their colleagues has been arrested, he or she expresses solidarity with the arrested individual and shows this by 'protesting' against the arrest.

Behaviour-assumption:

- Sympathizers of unofficial Islam disagree with the detention of all 'alleged terrorists' and show their solidarity with arrested co-citizens in their immediate neighbourhood

Figure 15: Arbitrary Arrests Lead to Protest

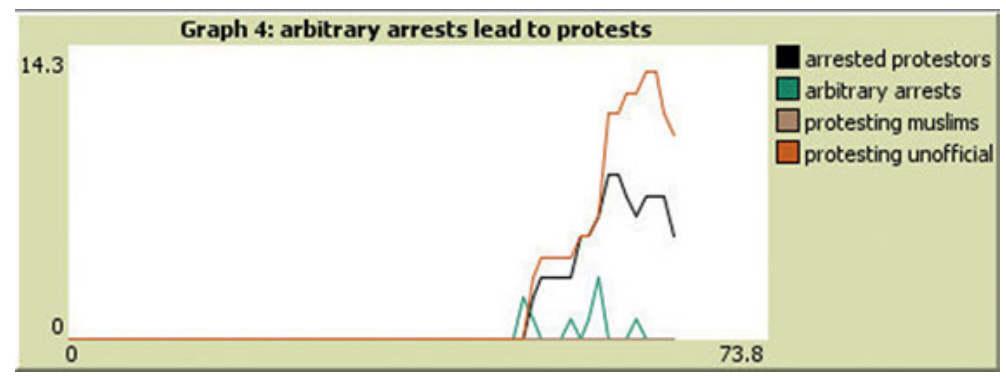

I interpret this to mean that the state loses legitimacy when an arbitrary arrest occurs resulting in a peaceful protest. The more devout Muslims are arrested, the more of them feel threatened by the state and protest against it. 
Figure 16: Clouds of Protestors Gather

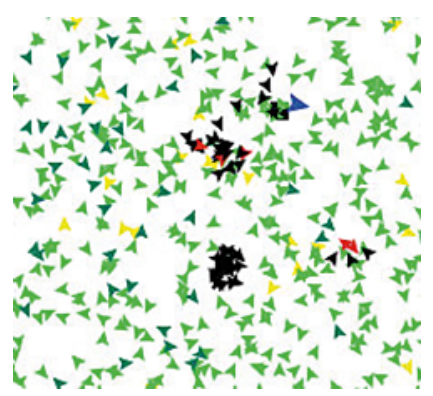

Legend:

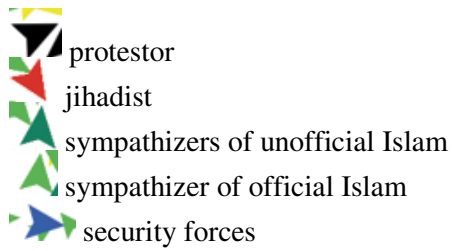

We can see in the figure above that around arrested individuals 'clouds' of protestors develop. This is the case because if any detained member of unofficial Islam is in the vicinity of another member of unofficial Islam, the latter will protest against the detention of the former. For this reason, the number of protestors rises disproportionately to the number of arbitrary detentions. We can furthermore observe how 'political Islam' (total number of individuals who have taken part in a protest on at least one occasion) comes to represent a substantial proportion of unofficial Islam.

Figure 17: Political Islam's Share of Unofficial Islam

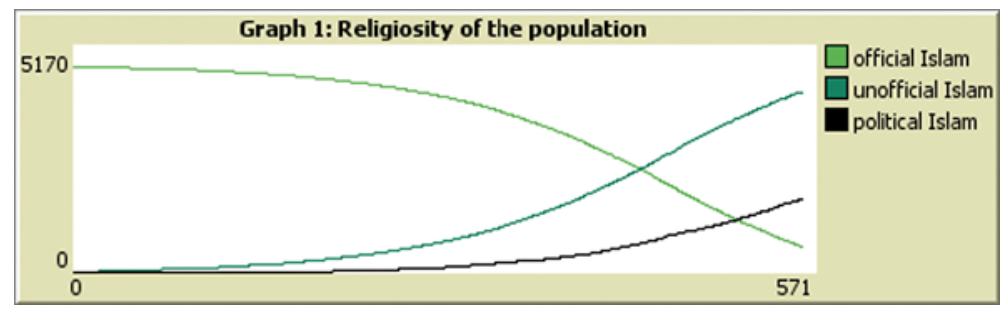




\subsection{Securitizing Moves}

\subsubsection{Detention of Sympathizers of Banned Groups}

If the security forces observe many representatives of unofficial Islam, they regard them additionally to jihadists as a threat and therefore ban and arrest them.

Behaviour assumptions:

- Security agents observe Muslims who are sympathizers of unofficial groups (globally)

- If their number is more than $0.1 \%$ (assumption) they start to securitize and arrest them

\subsubsection{Radicalization in Prison}

If sympathizers of unofficial Islam are detained arbitrarily or because they participated in a protest, they might be radicalized in prison. If they are radicalized, they become jihadists - they securitize the protest and attack security forces when they are set free. In the following graph we see how jihadists are gaining sympathizers.

Figure 18: Radicalized Detainees Released asJjihadists

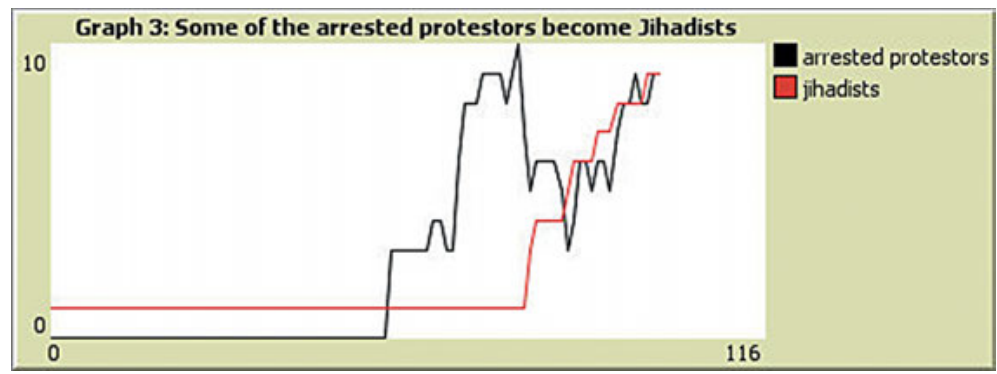

I assume that the harsher the security forces' treatment of alleged terrorists, the greater the probability that they will be radicalized in prison. One in ten detainees would be radicalized if no human rights abuses occurred. The po- 
litical terror scale is used as a multiplying factor for this assumption (the higher PTS, the more probable the radicalization).

Table 33: PTS (Simulation Parameter)

\begin{tabular}{|l|l|l|l|l|}
\hline & Kazakhstan & Kyrgyzstan & Tajikistan & Uzbekistan \\
\hline PTS $^{4}$ & 2.40 & 2.38 & 2.75 & 2.83 \\
\hline
\end{tabular}

$4 \quad 1-5$ (lower means fewer human rights abuses). 



\section{Model Verification and Validation}

\subsection{Sensitivity Analysis}

As the graphs above have already demonstrated, the revival of Islam, understood as the increasing influence of unofficial Islamic groups, could be simulated without difficulty.

In contrast to the gradual shift in religiosity, terrorist attacks were much more difficult to depict because they happen only occasionally. The main difficulty regarding the attacks was that the reach of the security forces is not supposed to exceed the reach of the terrorist attacks because otherwise no terrorist attacks would ever occur since the terrorists would be arrested 'preventively'. Therefore, I handpicked these parameters using probable empirical values. To arrive close to these, I chose the impact of terrorist attacks slightly greater than the reach of security forces.

The arrest of undesirable agents by security forces was easy to implement and quite similar to Epstein's civil violence model. As with Epstein, I too use a virtual prison-term for both detained terrorists (180 ticks) and detained protestors (40 ticks). This refers to around three to fifteen years in prison in the real world. The parameter is the same for all cases although in reality the sentences are not the same length in all countries. Nevertheless, since it is difficult to obtain reliable estimations of the average arrest-time, and also since the parameter does not have a great impact on the outcome, these differences were ignored.

The parameter protest-time was chosen for a short time only (5 timesteps) because if it is too long the protestors do not stop protesting if their neighbours are detained for a long time (however, this is gradually the case and therefore no problem with regards to sensitivity - the system should not be discarded because of this. 
Representing the probability of radicalization of arrested Muslims by the PTS-value of the respective countries was constructive. If I enhance the radicalization rate with a higher PTS the system reacts as it is supposed to: subsequently more terrorist attacks occur. The decision to include PTS as an empirical factor for further radicalization was a good one, as we will see in the next section.

I conclude that on the whole the model is robust, but draw special attention to the ratio of the reach of the security forces versus the reach of terrorist attacks. Diverse context-legitimacy values do not have a fundamental impact on the simulated 'revival of Islam'; rather the tendency is, as intended, either accelerated or decelerated.

\subsection{Verification: Mutual Reinforcement of SECURITIZation}

The model successfully represents the intended theoretical assumptions. Moreover, it describes the development of an escalating vicious circle of repression against devout Muslims and the radicalization of protestors and arbitrarily arrested individuals. In the eyes of the security forces, the detention of devout Muslims is well justified. Therefore they believe that citizens' protests against these detetions are illegitimate and undermine the authority of the state. As a result, security forces take action against the protestors and round them up. As we can see in the following example, no terrorist attacks or protests will take place unless the government starts to securitize: 
Figure 19: No Detentions and No Protests

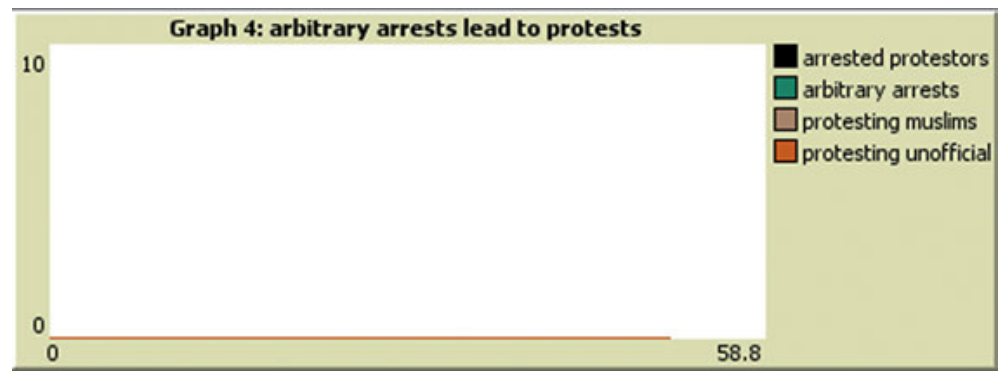

As soon as there are 50 sympathizers of unofficial Islam, however, the security forces start to arrest them arbitrarily, protest breaks out and the vicious circle gains momentum: the protestors themselves are then arrested which leads more individuals to protest:

\section{Figure 20: Detentions and Protests}

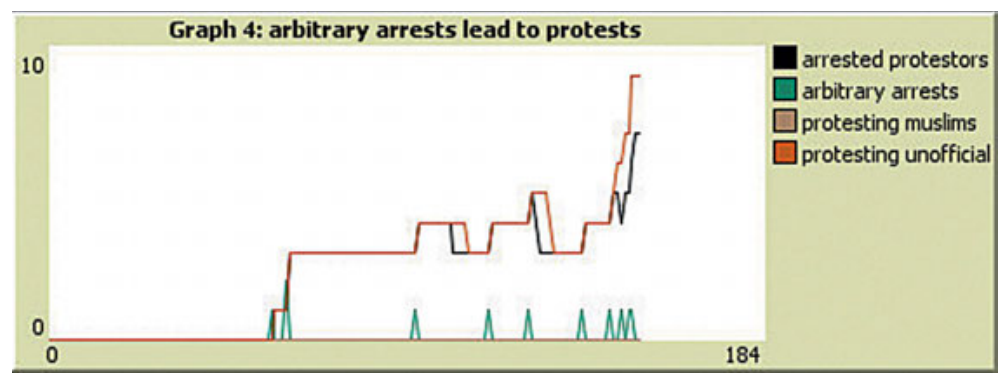

Here we see that initially the majority of devout Muslims are arrested arbitrarily - but they only act as a trigger. After some time (when the protestors become more numerous), the number of those who protest rises disproportionately to the number of arbitrary arrests: the conflict escalates. As a consequence, the number of protestors arrested and the number of those who are radicalized in prison and subsequently become jihadists increases. This then leads to more terrorist attacks: 
Figure 21: Protestors, Jihadists and Casualties

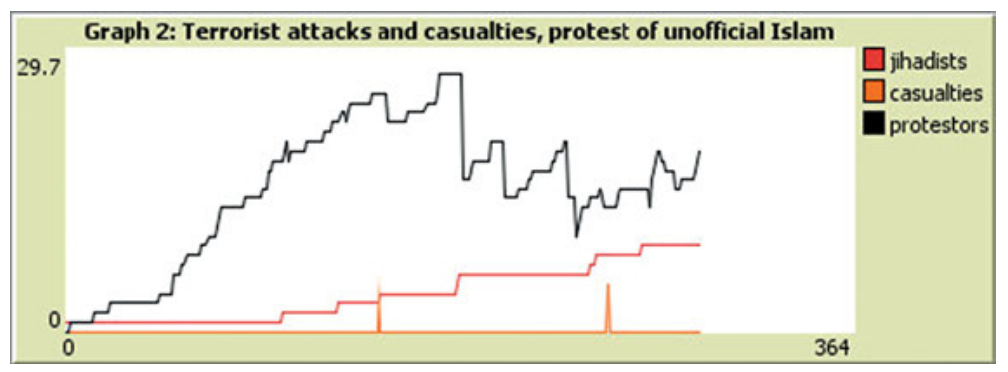

\subsection{Validation: Simulation Results and EMPIRICAL DATA}

The model represents not only the theoretical assumptions derived from the case studies and from securitization theory, but also has important similarities to the real world, as I will show in this section. The graphs presented here are the outcomes of ten runs for each case only (which is actually insufficient for deriving stochastically representative statements). Although the explanatory power of the simulation would be enhanced with the presentation of statistical analyses from the simulation outputs, to do so here would go beyond the scope of this study. ${ }^{1}$

I present here the correspondence of the simulation results with empirical data for the main reference values of the study:

- Terrorist attacks

- Securitization by state actor

- Violation of human rights by state actor (operationalized as arbitrary arrests of sympathizers of unofficial Islam)

1 For example, it would be possible to combine NetLogo mit $\mathrm{R}$ or Mathematica for this purpose. 


\subsubsection{Terrorist Attacks}

The actual number of suicide attacks is highest in Uzbekistan in contrast to Kyrgyzstan, which has recorded no attacks up until today. As terrorist attacks are very rare events, it is very difficult to obtain proper simulation results for them with my model. It was necessary to simulate a cross section of only 5,000 citizens from the total population because the program would not run correctly if the number were any higher. Due to the fact that significantly fewer than one out of 5,000 persons would commit such an attack, it was necessary to constrain ourselves with possible sympathizers of suicide attacks instead of with the terrorists themselves. For these reasons, the simulated terrorist attacks were much too frequent in our model (when extrapolated to the total population) and therefore would be better understood as potential terrorist attacks (because of the encounters between sympathizers of suicide attacks and security forces). However, if I divided my results by 10,000 (assuming that only one out of 10,000 possible attacks would really be executed), the result is very good: Uzbekistan displays the greatest potential for suicide attacks, followed by Kazakhstan, Kyrgyzstan and Tajikistan respectively. The table below shows the empirical and the simulated data for terrorist attacks.

Table 34: Validation of Terrorist Attacks

\begin{tabular}{|c|c|c|c|c|}
\hline & Kazakhstan & Kyrgyzstan & Tajikistan & Uzbekistan \\
\hline \multicolumn{5}{|l|}{ Empirical Data } \\
\hline $\begin{array}{l}\text { Number of Suicide } \\
\text { Attacks (Incidents) } \\
\text { (GTD) }\end{array}$ & 2 & 0 & 1 & 7 \\
\hline \multicolumn{5}{|l|}{ Simulation Results } \\
\hline $\begin{array}{l}\text { Extrapolated to the } \\
\text { whole Population }{ }^{2}\end{array}$ & 5.0 & 0.4 & 0.3 & 8.1 \\
\hline
\end{tabular}

2 Extrapolated for the total population and divided by 10,000 . 
The comparison of the simulated data with suicide attacks does not take the Tajik civil war into account because many 'conventional' terrorist attacks were reported there during this period which could not be represented in the simulation.

\subsubsection{Introduction of Securitization by State Actors}

In the real world, securitization by state actors means the introduction of restrictive religious laws. In the simulation here I compare the time span (years) since independence until these laws were introduced with the timespan (ticks) when securitizing behaviour by security forces began.

Table 35: Validation of Timing of Securitizaton by State Actors

\begin{tabular}{|c|c|c|c|c|}
\hline & Kazakhstan & Kyrgyzstan & Tajikistan & Uzbekistan \\
\hline \multicolumn{5}{|c|}{ Empirical Data } \\
\hline Name of Law & $\begin{array}{l}\text { Law on Reli- } \\
\text { gious Activity } \\
\text { and Religious } \\
\text { Associations } \\
\text { N 483-IV } \\
\text { 3PK }\end{array}$ & $\begin{array}{l}\text { On Freedom } \\
\text { of Conscience } \\
\text { and Religious } \\
\text { Organizations }\end{array}$ & $\begin{array}{l}\text { No 489. Law } \\
\text { on Freedom } \\
\text { of Conscinece } \\
\text { and Religious } \\
\text { Associations }\end{array}$ & $\begin{array}{l}\text { On Freedom } \\
\text { of Conscience } \\
\text { and Religious } \\
\text { Organizations }\end{array}$ \\
\hline In force since & 2011 & $\begin{array}{l}\text { (2009) } \\
\text { Amendments } \\
2012\end{array}$ & 2009 & 1998 \\
\hline \multicolumn{5}{|c|}{ Simulation Results } \\
\hline $\begin{array}{l}\text { Simulated ti- } \\
\text { me-steps until } \\
\text { securitizing } \\
\text { move by state } \\
\text { actor starts }\end{array}$ & 46.6 & 59.3 & 1.1 & 1.0 \\
\hline
\end{tabular}


As in the real world, so too in the simulation were those two states with the most significant religious populations the first to begin the securitization of unofficial Islam. The comparison of the order in which securitization commenced is therefore represented correctly. However, the simulated difference in time between them could be more accurate - Tajikistan is actually closer to Kazakhstan although it was the second government to introduce securitizing religious policies. An important fact in this regard is that the fatwas of the Tajik Muftiate started to be very restrictive in the early 2000s already. (I consider here only the 2012 law in Kyrgyzstan because it is much more restrictive than the 2009 law.) Tajikistan is a special case anyway as it witnessed a civil war between secular forces and an opposition with Islamist participation in the early 1990s.

\subsubsection{Arbitrary Arrests, Religious Persecution and Banned Groups}

Although Kazakhstan was the second last government to begin the securitization of Islam, in reality it catches up to Tajikistan in terms of the number of people detained on religious grounds. As the simulation displays, albeit in a slightly exaggerated form, this is also the case in the real world. This exaggerated effect does not pose a problem because it may even come closer to reality if I measure state repression against unofficial Islam not only by calculating the number of arbitrary arrests in the real world but also by using the ARDA religious persecution index. Kazakhstan receives a three point grade by this index after Uzbekistan (six points) with Kyrgyzstan and Tajikistan, which are much less restrictive, receiving only one point. (I assume here that restrictions on religion have a direct impact on the number of arrests on religious grounds as the main restriction in these countries is the banning of religious groups whose sympathizers are subsequently imprisoned for being sympathizers of an illegal organization.) If we compare the ARDA index to my simulation results of arbitrary arrests (as an indicator of the actual state repression of religious groups), we see that it corresponds to it perfectly. However, the data in the table below are the simulation outputs divided by 1,000 . Here too the same problem we encountered with the attacks persists: the very low numbers cannot be represented correctly in a simulation of only 5,000 citizens. 
Table 36: Validation of Constraints on Religious Freedom

\begin{tabular}{|c|c|c|c|c|}
\hline & Kazakhstan & Kyrgyzstan & Tajikistan & Uzbekistan \\
\hline \multicolumn{5}{|l|}{ Empirical Data } \\
\hline $\begin{array}{l}\text { Religious persecution } \\
\text { Index (ARDA) }{ }^{3}\end{array}$ & 3 & 1 & 1 & 6 \\
\hline $\begin{array}{l}\text { Estimations of current } \\
\text { detentions on religious } \\
\text { grounds }\end{array}$ & 350 & 50 & 350 & 7,000 \\
\hline \multicolumn{5}{|l|}{ Simulation Results } \\
\hline $\begin{array}{l}\text { arbitrary arrests, extra- } \\
\text { polated for the whole } \\
\text { population (total) }\end{array}$ & 374 & 41 & 50 & 719 \\
\hline
\end{tabular}

These results furthermore are in agreement with my findings which show that Kyrgyzstan and Tajikistan are more open to non-traditional or political Islamic groups than the other two countries, although Kazakhstan is still less restrictive than Uzbekistan in this regard as well. The replication of the approximations of religiously motivated arrests provided by Memorial member of staff Vitaly Ponomarev is not totally correct. Whereas these estimations for the real world refer to the number of current detainees on religious grounds, my simulated data refer to the total number of arrests since the beginning of the simulated process (as the detention time for alleged terrorists is very long, this does not disturb the comparison too much, though). Although the 'ranking' of the countries is once again correct, the measure for Tajikistan is too low and should be closer to Kazakhstan not Kyrgyzstan. Furthermore, the exceptionally high figures for Uzbekistan cannot be adequately accounted for. Despite this, a representation of state restrictions on religion using the simulated data on arbitrary arrests can be said to be quite successful overall.

3 Lower means less persecution. 
Some concluding remarks on the validity of my model:

- A clear representation in the simulation of restrictions on religious freedom by means of arbitrary arrests.

- In a comparison of the four cases, terrorist attacks are correctly represented in the model although too frequently for a population of 5,000.

- The introduction of the securitizing move by governments is clearly explained by a minimum-number of sympathizers of unofficial Islam. Tajikistan is the least well represented case in this regard but this depends on the interpretation: if we take the civil war - with the antecedent criminalisation of the IRPT - into account, the result might even be correct in this case. 



\section{Conclusions}

\subsection{CONCLUSIONS FROM COMPUTER Simulation}

A simulation is a simplified picture of the world. The results presented above show that my simulation cannot explain the whole ongoing conflict between Central Asian governments and non-traditional Muslims. However, it does show that some mutual reinforcement - as assumed by securitization theory - occurs and drives the opponents into a vicious circle of repression and radicalization.

In concluding that securitization is an important catalyst for the conflict, it is important to observe that contrary to government fears that unofficial Islam would give rise to political Islam, extremism and terrorism, this has not so far been the case: the total number of sympathizers of unofficial groups does not necessarily correspond to the number of attacks that occur - instead, the number of arbitrary arrests of sympathizers of peaceful unofficial Islamic groups seems to be the crucial factor in determining how many terrorist attacks will be carried out.

Figure 22: Simulation Results

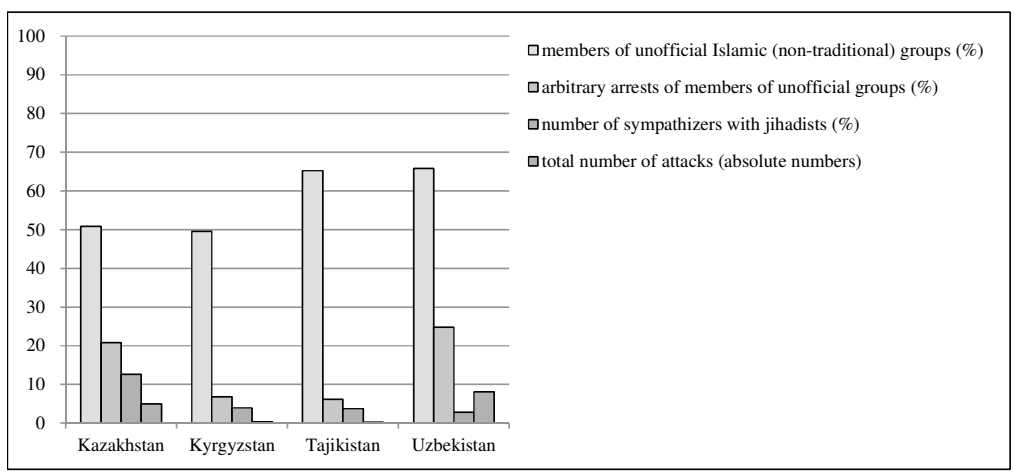


Securitization theory explains how repressive governmental measures lead to the radicalization of Islamists and vice versa: thus a mutually antagonistic vicious circle develops. As we can see from the graph above, in those cases where repression is higher, more terrorist attacks occur. Therefore, the vicious-circle hypothesis cannot be falsified with my simulation model.

I therefore conclude:

A vicious circle between repressive counter-terrorism measures and the radicalization of Muslims persists in Central Asia.

More concretely, the simulation results show:

- The more sympathizers of unofficial groups there are the more the state feels threatened by them and the more of them are arrested by security forces.

- There is no correlation between the number of sympathizers of unofficial groups and the number of terrorist attacks.

- The higher the number of arbitrary arrests of sympathizers of unofficial groups the more terrorist attacks are carried out.

It is important to note, however, that the fears of both parties in the conflict are not imaginary but rather tend to provoke disproportionate responses from the opposing side. This leads to an escalation. My model does not include possible deterrence through extremely disproportionate repression. Although this would be interesting to elaborate on, since this too is certainly a reality, to stress the radicalizing effect of repression too much might be short-sighted.

\subsection{General Concluding Remarks}

Both Central Asian governments and radical Islamic groups depend on being perceived as legitimate by the broader public. My hypothesis states that - contrary to the intended effect - legitimacy shifts from the state to the (Islamic) opposition forces if citizens suffer undifferentiated repression at the 
hands of government bodies. As my hypothesis cannot be falsified, I assume that in this way a vicious circle between radical Islam and Central Asian states developed. Initiated by the general revival of Islam, the Central Asian governments came to fear non-traditional Islam as a social and political opposition challenge to their power, which in turn led to the introduction of repressive religious policies. This led to governmental repression, not only of members of political and extremist movements but also of ordinary people practising Islam in a strict way - or dressing accordingly. This is particularly the case in Uzbekistan and Tajikistan but more recently also to an increasing degree in Kazakhstan and Kyrgyzstan.

I have evidence that restrictive religious policies which outlaw moderate fundamentalists successfully diminish the influence of these groups. However, the price for this is high if at the same time the few Salafis who are not directly affected are radicalized to such an extent that they see all means of opposing such repression as justified. I would like to exemplify this again with the two extreme examples used in the introduction to this study: Kyrgyzstan and Uzbekistan. As I have shown in chapter 9, the religious policies of the Central Asian states have had a huge impact on the practice of religion and on the attendance of religious services. In Kyrgyzstan, where only political Salafism is prohibited and apolitical forms of Islam are legal, scripturalist interpretations of Islam and religious worship are on the increase. Nevertheless, this country, which has a high percentage of people who sympathize with Islamist terrorism, has experienced no terrorist attacks up to this day. Conversely, in Uzbekistan, a country where devout religious practices are decreasing, all Salafi groups without exception are strongly persecuted and yet the country has sustained the highest number of terrorist acts of all Central Asian countries and the highest loss of life both through state repression and Islamist attacks.

Even if I recommend being tolerant towards non-violent Islamists, concerns of secular Central Asians who fear that political Salafis want to introduce conservative sharia laws have to be taken very seriously. From my point of view, however, only the rule of law can prevent possibly inhuman political demands of such groups. Despite this, it is important to note that the legalization of political Islam does entail that it may gain more members.

To conclude, I would like to challenge the efficacy of state repression against unofficial Islam with the following normative question: is the re- 
striction of an individual's human rights legitimate in order to protect the abstract concept of an authoritarian regime's national security? It is possible that the answer to this question is a very simple one. Or, in the words of Fetullah Gülen, a leader who is regarded either as an initiator of religious dialogue or a possible terrorist, depending on which side of the conflict you are on:

"The Quran says that the killing of a human being is equal to the killing of all humankind" (Gülen 2012, translated by the author).

If we take a narrow view of a specific situation, limited through situative perceptions, arguments and interests, the instrumentalization of the individual in order to achieve a 'higher' goal might seem legitimate. From a more global perspective, however, the life or integrity of an individual cannot be sacrificed to ensure the security of a whole population since the only means of measuring that very security is the violation or integrity of the individual.

My study shows that the militarily relatively strong countries, if measured against the number of attacks which actually occurred, do not provide better national security than the weaker countries. Instead, they fare worse not only with regards to national security but also with regards to human security and the protection of human rights. A possible explanation for this is that the countries with higher capacities are more capable of implementing their securitizing policies and therefore have to suffer more under its effects. This is an important finding that adds a clearly elucidated argument to the theoretical security discourse on how to define security. 


\section{Literature}

AI - Amnesty International (2013): Return to Torture. Extradition, Forcible Returns and Removals to Central Asia. Available at: http://www. amnesty.org/en/library/asset/EUR04/001/2013/en/6c3910ea-30bb4b67-a7f2-b2ffc5780a09/eur040012013en.pdf (26.1.2014).

Aitpaeva, Gulnara (ed.) (2007): Mazar worship in Kyrgyzstan: Rituals and Practitioners in Talas. Bishkek: Aigine Research Center.

Aitpaeva, Gulnara (ed.) (2009): Sacred Sites of Ysyk-Köl: Spiritual Power, Pilgrimage, and Art. Bishkek: Aigine Research Center.

Akdag, Muhammed Mustafa (2012): Der interreligiöse und interkulturelle Dialog im Koran. Gülen News. Available at: http://gulennews.de/ autoren/98-m-mustafa-akdag/214-der-interreligioese-undinterkulturelle-dialog-im-koran\#sthash.m8x0wNZP.dpuf (7.2.2014).

Al Treiki, Hadeel (2003): The Concept of Terrorism in a changing world. In: Calliess, Jörg (ed.): Was taugt die Entwicklungspolitik im Kampf gegen den Terrorismus? Rehburg-Loccum: Evangelische Akademie Loccum. p. 29-36.

Algar, Hamid (2009). Naqshbandiyah. In: Esposito, John L. (ed.) (2009): The Oxford Encyclopaedia of the Islamic World. New York: Oxford University Press. Vol. 4. p. 219-222.

Allan, Pierre and Stahel, Albert (1983): Tribal Guerilla Warfare against a Colonial Power: Analyzing the War in Afghanistan. The Journal of Conflict Resolution, Vol. 27, No. 4 (Dec. 1983). p. 590-617.

Anderson, John (1999): Kyrgyszstan. Central Asia's Island of Democracy? London and New York: Routledge.

Anichkova, Daria (2012): Central Asia's Migrant Headache. Carnegie Endowment for International Peace. Available at: http://carnegieendow 
ment.org/ieb/2012/06/21/central-asia-s-migrant-headache/c41a (30.9.2013).

Antonikis, Alyssa (2012): Cotton Picking in Uzbekistan: A Child Labor Industry. The Human Rights Brief. Center for Human Rights and Humanitarian Law. Available at: http://hrbrief.org/2012/11/cotton-pickingin-uzbekistan-a-child-labor-industry/ (30.9.2013).

ARA, Agency for Religious Affairs of the Republic of Kazakhstan: Список зарубежных организачий запрещенных по решению суда на территории Республики Казахстан. АГЕНТСТВО РЕСПУБЛИКИ КАЗАХСТАН ПО ДЕЛАМ РЕЛИГИЙ. Available at: http://www.din. gov.kz/rus/press-sluzhba/spisok_terroristicheskix_i_jek/ (19.9.2013).

ARDA, Association of Religion Data Archives: National Profiles. Available at: http://www.religionandstate.org/ (26.9.2013).

ARDA (KZ), Association of Religious Data Archives: National Profiles: Kazakhstan. Available at: http://www.thearda.com/internationalData/ countries/Country_120_1.asp (27.9.2013).

ARDA (KG), Association of Religious Data Archives: National Profiles: Kyrgyzstan. Available at: http://www.thearda.com/internationalData/ countries/country_126_1.asp (27.9.2013).

ARDA (TJ), Association of Religious Data Archives: National Profiles:

Tajikistan. Available at: http://www.thearda.com/internationalData/ countries/country_218_1.asp (27.9.2013).

ARDA (UZ), Association of Religious Data Archives: National Profiles: Uzbekistan. Available at: http://www.thearda.com/internationalData/ countries/country_236_1.asp (27.9.2013).

Aris, Stephen (2009): The Shanghai Cooperation Organisation: 'Tackling the Three Evils'. A Regional Response to Non-traditional Security Challenges or an Anti-Western Bloc? Europe-Asia Studies, Vol. 61, Issue 3, 2009. Available at: http://www.tandfonline.com/doi/abs/10.1080/ 09668130902753309\#.UnQNhOKsfu4 (1.11.2913).

Asia-Plus (2013): 6,000 Tajik nationals expected to perform Hajj this year. Available at: http://www.news.tj/en/news/6000-tajik-nationals-expected -perform-hajj-year (18.9.2013).

Asia Plus (2014): IRP activist dies in prison hospital two months after falling from the 3rd floor of Isfara police station. Available at: http://www. news.tj/en/news/irp-activist-dies-prison-hospital-two-months-afterfalling- $3^{\text {rd }}$-floor-isfara-police-st (2.2.2014). 
Atkin, Muriel (2009): Tajikistan. In: Esposito, John L. (ed.) (2009): The Oxford Encyclopaedia of the Islamic World. New York: Oxford University Press. Vol. 5, p. 307-309.

Axelrod, Robert (2005): Advancing the Art of Simulation in the Social Sciences. Forthcoming in Handbook of Research on Nature Inspired Computing for Economy and Management, Jean-Philippe Rennard (Ed.). Hersey, PA: Idea Group. Available at: http://www-personal.umich.edu/ axe/research/AdvancingArtSim2005.pdf (9.2.2014).

Axyonova, Vera; Boonstra, Jos; Marat Erica (2013): Security Sector Reform in Kazakhstan, Kyrgyzstan and Tajikistan: What Role for Europe? EUCAM Working Paper 14. Available at: http://www.fride.org/down load/EUCAM_WP14_SSR_Kazakhstan_Kyrgyzstan_Tajikistan.pdf (5.11.2013).

Balzacq, Thierry (ed.) (2011): Securitization Theory: How Security Problems Emerge and Dissolve. PRIO New Security Studies. London: Routledge.

BBC (2011a): Kazakhstan President Nazarbayev wins re-election. Available at: http://www.bbc.co.uk/news/world-asia-pacific-12949853 (29.9. 2013).

BBC (2011b): Kazakhstan: Nazarbayev rejects plan to scrap elections. Available at: http://www.bbc.co.uk/news/world-asia-pacific-12135440 (29.9.2013).

Beehner, Lionel (2005): ASIA: U.S. Military Bases in Central Asia. Council on Foreign Relations. Backgrounder. Available at: http://www.cfr. org/russia-and-central-asia/asia-us-military-bases-central-asia/p8440 (9.2.2014).

Bennigsen, Alexandre and Broxup, Marie (1983): The Islamic Threat to the Soviet State. Oxon: Routledge.

Bennigsen, Alexandre and Wimbush, S. Enders (1985) Mystics and Commissars, Sufism in the Soviet Union. Berkeley and Los Angeles: University of California Press.

Bensmann, Marcus (2012): Überschattete Wahlen im Reich Nasarbajevs. Neue Zürcher Zeitung. p. 7.

Berkley Centre (a): Spiritual Administration of Muslims in Kazakhstan. In: Resources on Faith, Ethics, and Public Live. Berkley Center for Religion, Peace \& World Affairs. Georgetown University. Available at: 
http://berkleycenter.georgetown.edu/resources/organizations/spiritualadministration-of-muslims-in-kazakhstan?q=Sunni (18.9.2013).

Berkley Centre (b): Religion in the Kazakh Constitution. In: Resources on Faith, Ethics, and Public Live. Berkley Center for Religion, Peace \& World Affairs. Georgetown University. Available at: http://berkley center.georgetown.edu/essays/religion-in-the-kazakh-constitution (18.9. 2013).

Berkley Centre (c): Spiritual Administration of Muslims of Kyrgyzstan. In: Resources on Faith, Ethics, and Public Live. Berkley Center for Religion, Peace \& World Affairs. Georgetown University. Available at: http://berkleycenter.georgetown.edu/resources/organizations/spiritualadministration-of-muslims-of-kyrgyzstan?q=kazakhstan (18.9.2013).

Berkley Centre (d): Muslim Board of Uzbekistan. In: Resources on Faith, Ethics, and Public Live. Berkley Center for Religion, Peace \& World Affairs. Georgetown University. Available at: http://berkleycenter. georgetown.edu/resources/organizations/muslim-board-ofuzbekistan?q=uzbekistan (18.9.2013).

Berkley Centre (e): Religion in the Uzbek Constitution. In: Resources on Faith, Ethics, and Public Live. Berkley Center for Religion, Peace \& World Affairs. Georgetown University. Available at: http://berkley center.georgetown.edu/essays/religion-in-the-uzbek-constitution (18.9.2013).

Berkley Centre (f): Religious Freedom in Uzbekistan. In: Resources on Faith, Ethics, and Public Live. Berkley Center for Religion, Peace \& World Affairs. Georgetown University. Available at: http://Berkley center.georgetown.edu/essays/religious-freedom-in-uzbekistan (18.9.2013).

Berkley Centre (g): Spiritual Administration of Muslims of Kyrgyzstan. In: Resources on Faith, Ethics, and Public Live. Berkley Center for Religion, Peace \& World Affairs. Georgetown University. Available at: http://berkleycenter.georgetown.edu/resources/organizations/spiritualadministration-of-muslims-of-kyrgyzstan?q=kyrgyzstan (5.10.2013).

Berkley Centre (h): Spiritual Administration of the Muslims in Central Asia and Kazakhstan (SADUM). In: Resources on Faith, Ethics, and Public Live. Berkley Center for Religion, Peace \& World Affairs. Georgetown University. Available at: http://berkleycenter.georgetown. 
edu/resources/organizations/spiritual-administration-of-the-muslims-incentral-asia-and-kazakhstan-sadum?q=kazakhstan (5.10.2013).

Berzin, Alexander (1996): Die historische Interaktion zwischen den buddhistischen und islamischen Kulturen vor der Zeit des mongolischen Reichs. Das Berzin-Archiv. Available at: http://www.berzinarchives. com/web/de/archives/e-books/unpublished_manuscripts/historical_ interaction/pt1/history_cultures_06.html (2.9.2013).

Bielefeldt, Heiner (2011): Report of the Special Rapporteur on freedom of religion or belief, A/HRC/19/60 Available at: http://www.ohchr.org/ Documents/HRBodies/HRCouncil/RegularSession/Session19/A-HRC19-60_en.pdf (9.2.2014).

Bin Laden, Osama (1998): Interview. Frontline PBS. Available at: http:// www.pbs.org/wgbh/pages/frontline/shows/binladen/who/interview.html (9.2.2014).

Blair, Sheila and Bloom, Jonathan (2005a): Irak, Iran und Ägypten: Die Abbasiden und ihre Nachfolger. Geschichte. In: Hattstein, Markus; Delius, Peter (ed.) (2005): Islam. Kunst und Architektur. Potsdam: Tandem Verlag GmbH. p. 90-93.

Blair, Sheila and Bloom, Jonathan (2005b): Islamische Mongolen: Vom Mongolensturm zu den Il-Khanen Geschichte. In: Hattstein, Markus; Delius, Peter (ed.) (2005): Islam. Kunst und Architektur. Potsdam: Tandem Verlag GmbH. p. 388-391.

Blattman, Christopher and Miguel, Edward (2010): Civil War. In: Journal of Economic Literature. No. 48:1. p. 3-57.

Blua, Antoine (2013): Uzbekistan Among Few Countries Keeping Exit Visas. Radio Free Europe/Radio Liberty. Available at: http://www.rferl. org/content/uzbekistan-exit-visas/24834087.html (2.2.2014).

Borjian, Habib (1997): Economy in Tajikistan. Encyclopedia Iranica. Available at: http://www.iranicaonline.org/articles/economy-xii-in-taji kistan (9.2.2014).

Bräker, Hans (1989): Die sowjetische Politik gegenüber dem Islam. In: Kappeler et al. (ed.) Die Muslime in der Sowjetunion und in Jugoslawien. Markus Verlag Köln. p. 131-154.

Brzezinski, Zbigniew (2004): Die einzige Weltmacht. Amerikas Strategie der Vorherrschaft. $8^{\text {th }}$ edition. Frankfurt am Main: Fischer Verlag $\mathrm{GmbH}$. 
Bukharbaeva, Galima (2005): Uzbekistan: Former Mufti Criticises AntiIslamic Campaign. RCA Issue 137, 21.2.2005. IWPR. Available at: http://iwpr.net/report-news/uzbekistan-former-mufti-criticises-antiislamic-campaign (8.2.2014).

Buzan, Barry and Waever, Ole (2003): Regions and Powers. The Structure of International Security. Cambridge: Cambridge University Press.

Cannon, Byron D. (2009): Timurids. In: Esposito, John L. (ed.) (2009): The Oxford Encyclopaedia of the Islamic World. New York: Oxford University Press. Vol. 5, p. 280-283.

Canfield, Robert L. and Rasuly-Paleczek, Gabriele (ed.) (2011): Ethnicity, Authority and Power in Central Asia. New games great and small. New York: Routledge, Central Asian Studies Series.

Central Asia Online (2013): Nazarbayev signs anti-terrorism law. Available at: http://centralasiaonline.com/en_GB/articles/caii/newsbriefs/ 2013/01/05/newsbrief-01 (5.11.2013).

Cesari, Jocelyne (2009): The Securitisation of Islam in Europe. CEPS Challenge Programme. Available at: http://aei.pitt.edu/10763/1/1826. pdf (9.2.2014).

Chittick, William C. (2009): Sufism: Sufi Thought and Practice. In: Esposito, John L. (ed.) (2009): The Oxford Encyclopaedia of the Islamic World. New York: Oxford University Press. Vol. 5, p. 207-216.

CIA (2013): The World Factbook. Available at: https://www.cia.gov/ library/publications/the-world-factbook/wfbExt/region_cas.html (28.8.2013).

Clarke, Richard (ed.) (2005): Gegen die Krieger des Dschihad: der Aktionsplan. Ein Century Foundation Task Force Report. Hamburg: Hoffmann und Campe.

Clausewitz, Carl von (1952). Vom Kriege. 16. Aufl. Bonn: Ferd Dümmlers Verlag.

Corley, Felix (2012): Kyrgyzstan: Censorship amendments to Religion Law signed. Forum 18. http://www.forum18.org/archive.php?article_id= 1781 (22.1.2014).

Corley, Felix (2013): Kazakhstan: Religious freedom to suffer in antiextremist programme? Forum 18 News Service. Available at: http:// www.forum18.org/archive.php?article_id=1831\&pdf=Y (24.9.2013).

CSTO - Collective Security Treaty Organization. Basic facts. http://www. odkb.gov.ru/start/index_aengl.htm (1.11.2013). 
Cummings, Sally, N. (ed.) (2010): Symbolism and Power in Central Asia. Politics of the Spectacular. Routledge Europe-Asia Studies. Oxon: Routledge. Reproduction of Euope-Asia Studies, vol. 61, issue 7.

Daase, Christopher (2001): Terrorismus - Begriffe, Theorien und Gegenstrategien. Ergebnisse und Probleme sozialwissenschaftlicher Forschung. In: Friedens-Warte. Journal of international Peace and Organization. Vol. 76, No. 1, July 2001. p. 55-79. Available at: http://home page.univie.ac.at/vedran.dzihic/Daase.pdf (9.2.2014).

Dalbaeva, Alina (2014): Central Asia: A Dangerous Thirst. 28 January 2014 by Crisis Group. Available at: http://www.crisisgroupblogs.org/ across-eurasia/2014/01/28/central-asia-a-dangerous-thirst/\#more-352 (2.2.2014).

EIU, The Economist Intelligence Unit (2013): Democracy index 2012. Democracy at a standstill. A report from The Economist Intelligence Unit. The Economist Intelligence Unit Limited. Available at: https:// portoncv.gov.cv/dhub/porton.por_global.open_file?p_doc_id=1034 (27.11.2013).

Elger, Ralf (2002): Islam. Frankfurt am Mai: Fischer Taschenbuch Verlag.

Encylopaedia Britannica (a): Qarakhanid Dynasty. Available at: http:// www.britannica.com/EBchecked/topic/485479/Qarakhanid-Dynasty (3.9.2013).

Encylopaedia Britannica (b): First Mongol incursions. Available at: http://www.britannica.com/EBchecked/topic/295765/Islamic-world/ 26917/First-Mongol-incursions (3.9.2013).

Encylopaedia Britannica (c): Mu'tazilah. Available at: http://www. britannica.com/EBchecked/topic/399752/Mutazilah (4.9.2013).

Encylopaedia Britannica (d): Sāmānid dynasty. Available at: http://www. britannica.com/EBchecked/topic/520234/Samanid-dynasty (4.9.2013).

Encylopaedia Britannica (e): Khwārezm-Shāh Dynasty. Available at: http://www.britannica.com/EBchecked/topic/317161/Khwarezm-ShahDynasty (5.9.2013).

Encylopaedia Britannica (f): Mikhail Vasilyevich Frunze. Available at: http://www.britannica.com/EBchecked/topic/221145/MikhailVasilyevich-Frunze (29.1.2013).

Enderlein, Volkmar (2005): Syrien und Palästina: Das Kalifat der Umaiyaden. Geschichte. In: Hattstein, Markus; Delius, Peter (ed.) (2005): 
Islam. Kunst und Architektur. Potsdam: Tandem Verlag GmbH. p. 6063.

Epkenhans, Tim (2011): Defining normative Islam: some remarks on contemporary Islamic thought in Tajikistan - Hoji Akbar Turajonzoda's 'Sharia and society'. Central Asian Survey. Vol. 30, No. 1, March 2011, p. 81-96.

Epstein, Joshua (2006): Generative Social Sciences. Studies in AgentBased Computational Modeling. Princeton: Princeton University Press.

Esposito, John L. (ed.) (2009): The Oxford Encyclopedia of the Islamic World. Oxford/ New York: Oxford University Press.

EurasiaNet (2009): Kyrgyzstan: Human Rights Activists Condemn New Religion Law. Available at: http://www.eurasianet.org/departments /insightb/articles/eav011609c.shtml (22.1.2014).

EurasiaNet (2012a): Tajikistan: Using Force to Maintain a Standing Army. Eurasianet. Availble at: http://www.eurasianet.org/node/65222 (1.11.2013).

EurasiaNet (2012b): Uzbekistan: Where Conscripts Are Eager to Serve. Eurasianet. Availble at: http://www.eurasianet.org/node/65411 (1.11.2013).

EurasiaNet (2014): Lawmakers in Kazakhstan Split on Bride Kidnapping. Eurasianet. Available at: http://www.eurasianet.org/node/67969 (23.1.2014).

Ewing, K.P., Mannan, M. (2009): Pir. In: Esposito, John L. (ed.) (2009): The Oxford Encyclopedia of the Islamic World. Oxford/ New York: Oxford University Press. Vol. 4, p. 377-378.

Fathi, Habiba (2011): Female mullahs, healers, and leaders of Central Asian Islam. Gendering the old and new religious roles in postCommunist communities. In: Canfield, Robert L.; Rasuly-Paleczek, Gabriele (ed.): Ethnicity, Authority and Power in Central Asia. New games great and small. New York: Routledge, Central Asian Studies Series.

Fighel, Jonathan (2007): The 'Radicalization Process' in Prisons. Presented at N.A.T.O. workshop, Eilat, December 25 2007. Available at: http://www.ict.org.il/Portals/0/Articles/Radicalization\%20in\%20Prisons .pdf (9.2.2014).

Finke, Peter (2011): Central Asian attitutes towards Afghanistan. Perceptions of the Afghan war in Uzbekistan. In: Canfield, Robert L. \& Rasu- 
ly-Paleczek, Gabriele (ed.) (2011): Ethnicity, Authority and Power in Central Asia. New games great and small. New York: Routledge, Central Asian Studies Series.

Freedom House (2013a): Kazakhstan. Freedom in the World. Available at: http://www.freedomhouse.org/report/freedom-world/2013/kazakhstan (24.10.2013).

Freedom House (2013b): Kyrgyzstan. Freedom in the World. Available at: http://www.freedomhouse.org/report/freedom-world/2013/kyrgyzstan (24.10.2013).

Freedom House (2013c): Tajikistan. Freedom in the World. Available at: http://www.freedomhouse.org/report/freedom-world/2013/tajikistan (24.10.2013).

Freedom House (2013d): Uzbekistan. Freedom in the World. Available at: http://www.freedomhouse.org/report/freedom-world/2013/uzbekistan (24.10.2013).

Freedom House (2013e): Freedom in the World 2013: Democratic Breakthroughs in the Balance. Online at: http://www.freedomhouse.org/sites /default/files/FIW\%202013\%20Booklet_0.pdf (20.8.2013).

Frunse, Michail Wassiljewitsch (1885-1925): Ausgewählte Schriften. Berlin: Verlag des Ministeriums für Nationale Verteidigung (ed. 1956).

Geller, Armando (2007): Macht, Ressourcen und Gewalt: Zur Komplexität zeitgenössischer Konflikte. Eine agenten-basierte Modellierung. Zürich: vdf. *

Geller, Armando and Moss, Scott (2007): Growing Qawm: An EvidenceDriven Declarative Model of Afghan Power Structures. Advances in Complex Systems 11 (2): p. 321-335. *

Geller, Armando and Spencer, Bob (2009): Mobilizing Traditional Afghan Skills and Perceptions to Increase Rural Development and Security. Turkish Policy Quarterly 8 (2): p. 77-86. *

Geller, Armando; Latek, Maciej M.; Mussavi Rizi, Seyed M. (2012): Fusing remote sensing with sparse demographic data for synthetic population generation: an algorithm and application to rural Afghanistan. International Journal of Geographical Information Science 27 (5): p. 9861004. *

Gerholm, Tomas and Mubarak, Hadia (2009): Urf. In: Esposito, John L. (ed.) (2009): The Oxford Encyclopaedia of the Islamic World. New York: Oxford University Press. Vol. 5, p. 491-495. 
Gilbert, Nigel and Troitzsch, Klaus G. (2005): Simulation for the Social Scientist. 2. edition Berkshire: Open University Press.

Gilbert, Nigel (2009): Agent-Based Models. London: SAGE Publications.

Giardin, Luc; Peter, Marcel; Sanglard, Hervé (2002). Internationaler Terrorismus - Eine multidimensionale Analyse seines Umfelds mittels 'Clash'O'Scope'. Sonderbeitrag zur ASMZ, Vol. 168, No. 12, 2002. p. 8-16.

Gülen, Fetullah (2012): Terror, Islamische Welt, Verantwortung. Gülen News. Available at: http://gulennews.de/interviews-page/177-terrorislamische-welt-verantwortung (7.2.2014).

Hafez, Mohammed M. (2003): Why Muslims Rebel. Repression and Resistance in the Islamic World. London: Lynne Rienner Publishers.

Hagmann, Jonas (2009): Sicherheitspolitische Konzeptionen und Projektionen nationaler Experten. Military Power Revue der Schweizer Armee. No. 3, 2009: p. 28-41.

Halbach, Uwe (1989): 'Heiliger Krieg' gegen den Zarismus. Zur Verbindung von Sufismus und Djihad im antikolonialen islamischen Widerstand gegen Russland im 19. Jahrhundert. In: Kappeler, Andreas; Simon, Gerhard; Brunner, Georg (eds.) (1989): Die Muslime in der Sowjetunion und in Jugoslawien. Markus Verlag Köln. p. 213-234.

Halbach, Uwe (2010a): Die 'islamistische Gefahr' als sicherheitspolitisches Problem in Zentralasien. In: Reiter, Erich (ed.): Konfliktmanagement in Zentralasien. Internationales Institut für Liberale Politik Wien. Schriftenreihe zur internationalen Politik. Wien: Böhlau Verlag. p.83-96.

Halbach, Uwe (2010b): Militanter Islamismus: Brücke zwischen Zentralasien, Afghanistan und Pakistan? In: Reiter, Erich (ed.): Konfliktmanagement in Zentralasien. Internationales Institut für Liberale Politik Wien. Schriftenreihe zur internationalen Politik. Wien: Böhlau Verlag.

Hattstein, Markus (2005a): Mittel- und Kleinasien: Grossseldschuken, Anatolische Seldschuken und Khwarazm-Shahs. Geschichte. In: Hattstein, Markus; Delius, Peter (ed.) (2005): Islam. Kunst und Architektur. Potsdam: Tandem Verlag GmbH. p. 348-353.

Hattstein, Markus (2005b): Mittelasien: Timuriden, Shaibaniden und Khanfürstentümer. Geschichte. In: Hattstein, Markus; Delius, Peter (ed.) (2005): Islam. Kunst und Architektur. Potsdam: Tandem Verlag GmbH. p. 408-415. 
Haykel, Bernard (2009): Salafi Groups. In: Esposito, John L. (ed.) (2009): The Oxford Encyclopaedia of the Islamic World. New York: Oxford University Press. Vol. 5, p. 26-28.

Helmer, John (2008): IMF attacks Tajikistan Aluminium Co -- orders international audit. Mineweb. Available at: http://www.mineweb.com/ mineweb/content/en/mineweb-base-metals?oid=62257\&sn=Detail (2.10.2013).

Holzwarth, Wolfgang (2005): Die Schaibaniden und Khanfürstentümer. Geschichte. In: Hattstein, Markus; Delius, Peter (ed.) (2005): Islam. Kunst und Architektur. Potsdam: Tandem Verlag GmbH. P. 431-435.

HSRP - Human Security Report Project. Backgrounder. Available at: http://www.hsrgroup.org/press-room/human-security-backgrounder. aspx (20.7.2014).

Human Security Report (2006): Available at: http://www.hsrgroup.org/ human-security-reports/2006/overview.aspx (20.7.2014).

Human Security Report (2012): Available at: http://www.hsrgroup.org/ human-security-reports/2012/overview.aspx (20.7.2014).

HT - Hizb ut-Tahrir: Hizb ut-Tahrir. Available at: http://www.hizb-uttahrir.org/index.php/EN/def (7.2.2014).

Huntington, Samuel P. (2002): Kampf der Kulturen. Die Neugestaltung der Weltpolitik im 21. Jahrhundert. 4. edition. München: Wilhelm Goldmann Verlag.

ICG - International Crisis Group (2009): Central Asia: Islamists in Prison. Asia Briefing. No. 97, 15 December 2009. Available at: http://www. crisisgroup.org/ /media/Files/asia/central-asia/b97\%20Central\%20Asia \%20Islamists\%20in\%20Prison (9.2.2014).

ICG - International Crisis Group (2011): Central Asia: Decay and Decline. Asia Report No. 201, 3.2.2011. Executive Summary and Recommendations. Available at: http://www.crisisgroup.org/en/regions/asia/centralasia/201-central-asia-decay-and-decline.aspx (2.2.2014).

ICG - International Crisis Group (2012): Kyrgyzstan: Widening Ethnic Divisions in the South. Asia Report No. 222, 29.3.2012. Available at: http://www.crisisgroup.org/ /media/Files/asia/central-asia/kyrgyzstan/ 222-kyrgyzstan-widening-ethnic-divisions-in-the-south.pdf (27.9.2013).

ICG - International Crisis Group (2013): Kazakhstan: Waiting for Change. Asia Report No. 250, 30.9.2013. Available at: http://www.crisisgroup. 
org/en/regions/asia/central-asia/kazakhstan/250-kazakhstan-waiting-forchange.aspx (7.10.2013).

Interfax (2010): Kyrgyz mufti seeks to resign. Available at: http://www.interfax-religion.com/?act=news\&div=9524 (4.10.2013).

Isakova, Gulmira (2013): Kazakhstan to study nature of extremism. An understanding of its root causes could help defeat terrorism, analysts say. Central Asia Online. Available at: http://centralasiaonline.com/en_GB/ articles/caii/features/main/2013/10/17/feature-01 (28.10.2013).

Ismailbekova, Aksana and Nasritdinov Emil (2012) Transnational Religious Networks in Central Asia: Structure, Travel and Culture of Kyrgyz Tablighi Jama'at, Transnational Social Review.

Ismoilov, Sukhrobjon (2009): Freedom of Religion or Belief in Uzbekistan. A Policy Brief for the OSCE Supplementary Human Dimension Meeting on Freedom of Religion or Belief, Vienna, 9-10 July, 2009. Expert Working Group (EWG), Tashkent, Ubzekistan. Available at: http://www.osce.org/odihr/38053 (9.2.2014).

IWPR - Institute for War and Peace Reporting (2011): Uzbeks Underwhelmed by Constitutional Reform. Available at: http://iwpr.net/reportnews/uzbeks-underwhelmed-constitutional-reform (27.9.2013).

IWPR - Institute for War and Peace Reporting (2013a): Uzbek Leader Wakes Up to Mass Emigration Available at: http://iwpr.net/reportnews/uzbek-leader-wakes-mass-emigration (27.9.2013).

IWPR - Institute for War and Peace Reporting (2013b): Uzbek Conscripts Pay for Shorter Army Service. News Briefing Central Asia. Available at: http://iwpr.net/report-news/uzbek-conscripts-pay-shorter-armyservice (6.11.2013).

Johansen, J. E. A and Talib, Mohammad (2009): Sufism: Sufism and Politics. In: Esposito, John L. (ed.) (2009): The Oxford Encyclopaedia of the Islamic World. New York: Oxford University Press. Vol. 5, p. 233243.

Kamalova, Nozima (2007): The War On Terror and its Implications for Human Rights in Uzbekistan. The Woodrow Wilson International Center for Scholars. Available at: http://www.wilsoncenter.org/sites/default /files/OP296.pdf (9.2.2014).

Kamuluddin, Sadykzhan (2005): Hizb ut-Tahrir Today. An Interview with Kamuluddin by Igor Rotar. Jamestown Foundation. Publication: Terrorism Monitor Vol. 2, Issue 5. Available at: http://www.jamestown.org 
/programs/gta/single/?tx_ttnews\%5Btt_news\%5D=416\&tx_ttnews\%5B backPid\%5D=179\&no_cache=1 (27.6.2014).

Kaplony, Andreas (2005): Handel und Verkehr in Zentralasien in der Darstellung der arabisch-persischen Geographie. Available at: http://www. research-projects.uzh.ch/p3005 (6.9.2013).

Kappeler, Andreas; Simon, Gerhard; Brunner, Georg (eds.) (1989): Die Muslime in der Sowjetunion und in Jugoslawien. Köln: Markus Verlag.

Karabayev, Aibek (2011): Kyrgyzstan says extremists employ unschooled imams. Central Asia Online. Available at: http://centralasiaonline.com/ en_GB/articles/caii/features/main/2011/01/07/feature-01 (4.10.2013).

Karagiannis, Emmanuel (2010): Political Islam in Central Asia. The Challenge of Hizb ut-Tahrir. London: Routledge.

Kehl-Bodrogi, Krisztina (2006): Who owns the shrine? Competing meanings and authorities at a pilgrimage site in Khorezm. Central Asia Survey. Vol., Issue 3, September 2006. p. 235-250.

Keller, Shoshana (2001): To Moscow, not Mecca. The Soviet Campaign Against Islam in Central Asia, 1917-1941. Westport: Praeger.

Khalid, Abeed (2007): Islam after Communism. Religion and Politics in Central Asia. London: University of California Press.

Khamidov, Alisher (2009): Islamic Movement of Uzbekistan. In: Esposito, John L. (ed.) (2009): The Oxford Encyclopaedia of the Islamic World. New York: Oxford University Press. Vol. 3, p. 153-155.

Khazanov, Anatoly (2005): Authoritarianism and its consequences in exSoviet Central Asia. In: Canfield, Robert L. \& Rasuly-Paleczek, Gabriele (ed.) (2011): Ethnicity, Authority and Power in Central Asia. New games great and small. New York: Routledge, Central Asian Studies Series. p. 19-38.

Kilner, James (2012): Kyrgyzstan is a beacon of democracy in autocratic Central Asia says ex-leader. Available at: http://www.telegraph.co.uk/ news/worldnews/asia/kyrgyzstan/9336616/Kyrgyzstan-is-a-beacon-ofdemocracy-in-autocratic-Central-Asia-says-ex-leader.html (26.6.2014).

Kucera, Joshua (2010): Kazakhstan's military-industrial complex struts its stuff. Eurasianet. http://www.eurasianet.org/node/61162 (26.6.2014).

Kucera, Joshua (2012): Kazakhstan: Weapons on Parade, But Army Band Steals the Show. Pulitzer Center on Conflict Reporting. Available at: http://pulitzercenter.org/reporting/kazakhstan-kadex-astana-weaponsarmy-band-dancing-queen (1.11.2013). 
Kuspinar, Bilal (2009): Said Nursi. In: Esposito, John L. (ed.) (2009): The Oxford Encyclopaedia of the Islamic World. New York: Oxford University Press. Vol. 4, p. 260-262.

Kuster, Matthias (2006): Clausewitz für Terrorbekämpfer. ASMZ, Vol. 172, No. 10, 2006. p. 47-48.

KZ GOV* - Kazakh Government: http://en.government.kz/structure/ org/a21 (26.3.2014).

KZ MIA - Ministry of Internal Affairs of the Republic of Kazakhstan (2013): Embassy of the United States has provided technical support to the Special police detachment MIA. Available at: http://www.vkd.tj/ index.php/en/news/46-khabarkhoeng/2912-embassy-of-the-unitedstates-has-provided-technical-support-to-the-special-police-detachmentmia (6.11.2013).

KZ Strategy 2050: Contract soldiers to compose 99 per cent of army by 2016 - Kazakh Defense Ministry. Available at: http://strategy2050.kz/ en/news/2011/ (6.11.2013).

Lang, Józef (2012): An increasing crisis in Kyrgyzstan - moving towards a fallen state. Centre for Eastern Studies (OSW). Available at: http://www.osw.waw.pl/en/publikacje/eastweek/2013-06-12/increasingcrisis-kyrgyzstan-moving-towards-a-fallen-state (2.10.2013).

Léonard, Christian and Kaunert, Sarah (2011): Reconceptualizing the audience in securitization theory. In: Balzacq, Thierry (ed.) (2011): Securitization Theory: How Security Problems Emerge and Dissolve. PRIO New Security Studies. London: Routledge. p. 57-76.

Levy, Clifford J. (2009): Strategic Issues, Not Abuses, Are U.S. Focus in Kyrgyzstan. New York Times. http://www.nytimes.com/2009/07/23/ world/asia/23kyrgyz.html (29.9.2013).

Lillis, Joanna (2011): Kazakhstan Official Blames Mafia for Suicide Bombing. EurasiaNet. http://www.eurasianet.org/node/63499 (23.1.2014)

Lillis, Joanna (2013): Kazakhstan: Astana Mulls Expansion of Anti-Terror Controls. EurasiaNet. http://www.eurasianet.org/node/67146 (24.9.2013).

Litovkin, Viktor (2012): Uzbekistan wants American weapons and suspends CSTO membership. Valdai Discussion Club. Available at: http://valdaiclub.com/near_abroad/45740.html (8.2.2014).

Louw, Maria Elisabeth (2007): Everyday Islam in Post-Soviet Central Asia. Central Asian Studies Series. London and New York: Routledge. 
Marat, Erica (2010): The Military and the State in Central Asia. From Red Army to Independence. Central Asian Studies Series. London \& New York: Routledge.

Marat, Erica (2012): Security Sector Reform in Central Asia. The Geneva Centre for the Democratic Control of Armed Forces. Geneva: DCAF Regional Programmes. Available at: http://www.dcaf.ch/Publications/ Security-Sector-Reform-in-Central-Asia (1.11.2013).

Mardin, Serif (2009): Nurculuk. In: Esposito, John L. (ed.) (2009): The Oxford Encyclopaedia of the Islamic World. New York: Oxford University Press. Vol. 4, p. 257-259.

Matveeva, Anna (1999): Democratization, legitimacy and political change in Central Asia. International Affairs, No. 75/1. p. 23-44.

Matveeva, Anna (2005): Tajikistan: Evolution of the Security Sector and the War on Terror. National Defence Academy and Bureau for Security Policy at the Austrian Ministry of Defence in co-operation with Geneva Centre for the Democratic Control of Armed Forces, Switzerland, and PfP Consortium of Defence Academies and Security Studies Institutes, Garmisch-Partenkirchen, Germany. Accessible at: http://www.isn.ethz. ch/Digital-Library/Publications/Detail/?ots591=0c54e3b3-1e9c-be1e2c24-a6a8c7060233\&lng=en\&id=91412 (5.11.2013).

Matveeva, Anna (2010): Legitimising Central Asian authoritarianism: political manipulation and symbolic power. In: Cummings, Sally, N. (ed.): Symbolism and Power in Central Asia. Politics of the Spectacular. Routledge Europe-Asia Studies. Oxon: Routledge. Reproduction of Europe-Asia Studies. Vol. 61, issue 7. p. 12-38.

McChrystal, Standley (2009): Tactical Directive. Kabul: NATO/ISAF. Available at: http://www.nato.int/isaf/docu/official_texts/Tactical_ Directive_090706.pdf (22.9.2010).

McDermott, Roger N. (2013): Kazakhstan introduces new counter-terror strategy. Kazakhstan Newswire. Available at: http://www.universal newswires.com/centralasia/kazakhstan/general/viewstory.aspx?id= 13990 (28.10.2013).

McDonald, Matt (2008): Securitization and the Construction of Security. European Journal of International Relations. Vol. 14, No. 4/2008. p. 563-588. 
McGlinchey, Eric M. (2006): Islamic Leaders in Uzbekistan. In: Asia Policy. No. 1, January 2006. p. 123-144. Available at: http://mason.gmu. edu/ emcglinc/ap1-mcglinchey.pdf (31.1.2014).

Meyer, Thomas (2002): Vom Missbrauch kultureller Unterschiede. Berlin: Suhrkamp Verlag.

Mingisheva, Nazgul (2011): Education and Islam Growth in Modern Kazakhstan. http://www.academia.edu/1687081/Education_and_Islam_ Growth_in_Modern_Kazakhstan (18.9.2013).

Moreno, Alejandro (2012): Ending Impunity: The Use of Forensic Medical Evaluations to Document Torture and Ill Treatment in Kyrgyzstan. Physicians for Human Rights. Available at: http://physiciansforhuman rights.org/library/reports/ending-impunity-forensic-medical-evaluations -in-kyrgyzstan.html (6.11.2013).

Morozova, Irina (2004): Legal systems and political regimes in postsocialist Central Asia. IIAS Newsletter No. 34, July 2004. Available at: http://www.iias.nl/nl/34/IIAS_NL34_16.pdf (5.10.2014).

Murzakulova, Asel and Schoeberlein, John (2010): The invention of legitimacy: struggles in Kyrgyzstan to craft an effective nation-state ideology. In: Cummings, Sally, N. (ed.) (2010): Symbolism and Power in Central Asia. Politics of the Spectacular. Routledge Europe-Asia Studies. Oxon: Routledge. Reproduction of Euope-Asia Studies. Vol. 61, issue 7. p. 144-163.

Mumtaz, Ahmad and Reetz, Dietrich (2009): Tablighi Jama'at. In: Esposito, John L. (ed.) (2009): The Oxford Encyclopaedia of the Islamic World. New York: Oxford University Press. Vol. 5, p. 293-299.

Nabiyeva, Dilafruz (2013): Tajikistan focuses on education to prevent extremism. Central Asia Online. Available at: http://centralasiaonline.com /en_GB/articles/caii/features/main/2013/05/02/feature-01 (26.6.2014).

Naby, Eden (2009): Islamic Renaissance Party. In: Esposito, John L. (ed.) (2009): The Oxford Encyclopaedia of the Islamic World. New York: Oxford University Press. Vol. 3, p. 157-159.

Nasritdinov, Emil (2012): Spiritual Nomadism and Central Asian Tablighi Travelers. In: Ab Imperio, No. 2/ 2012. p. 145-162.

NATO - North Atlantic Treaty Organization: NATO Partners. http://www. nato.int/cps/en/natolive/51288.htm (1.11.2013).

Naumkin, Vitaly V. (2005): Radical Islam in Central Asia. Between Pen and Rifle. Lanham: Rowman \& Littlefield Publishers, Inc. 
Nazarov, Ulan (2912): Kyrgyzstan changes Hajj procedures. Central Asia Online. Available at: http://centralasiaonline.com/en_GB/articles/caii/ features/main/2012/06/22/feature-01 (7.10.2013).

NewsOK (2011): Officials: 16 dead in abortive Kazakh prison break. Available at: http://newsok.com/officials-16-dead-in-abortive-kazakhprison-break/article/feed/275500 (8.2.2014).

Nichol, Jim (2013a): Kazakhstan: Recent Developments and U.S. Interests. Congressional Research Center. Available at: http://www.fas.org/sgp/ crs/row/97-1058.pdf (20.9.2013).

Nichol, Jim (2013b): Uzbekistan: Recent Developments and U.S. Interests. Congressional Research Centre. Available at: http://www.fas.org/sgp/ crs/row/RS21238.pdf (3.11. 2013).

Ohtsuka, Kazuo (2009): Sufism: Sufi Shrine Culture. In: Esposito, John L. (ed.) (2009): The Oxford Encyclopaedia of the Islamic World. New York: Oxford University Press. Vol. 5, p. 225-233.

Omelicheva, Mariya Y. (2011): Counterterrorism Policies in Central Asia. Central Asian Studies Series. London \& New York: Routledge.

Ostrowski, Wojciech (2010): Politics and Oil in Kazakhstan. Oxon: Routledge. Central Asian Studies.

OSW, Centre for Eastern Studies (2011): Uzbekistan: The Senate adopts constitutional amendments. http://www.osw.waw.pl/en/publikacje/east week/2011-03-30/uzbekistan-senate-adopts-constitutional-amendments (26.6.2014).

Pannier, Bruce (2007a): Kyrgyzstan: Does New Constitution Strengthen Democracy -- Or President Bakiev? Radio Free Europe/Radio Liberty. Available at: http://www.rferl.org/content/article/1079004.html (30.9.2013).

Pannier, Bruce (2007b): Tajikistan: Former Opposition Leader Urges Civil War Amnesty. Radio Free Europe/Radio Liberty. Availabe at: http://www.rferl.org/content/article/1075295.html (8.11.2013).

PARLINE (2013): Database on National Parliaments. Available at: http:// www.ipu.org/parline/ (9.2.2014).

Pelkmans, Mathijs (2006): Religion und Kultur in Zentralasien: Sowjetische Vermächtnisse und neue Herausforderungen. Jahrbuch 2006 des Max-Planck-Instituts. Available at: www.mpg.de/jahrbuch/forschungs bericht?obj=300302 (3.1.2012). 
Peters, Rudolph (2009): Jihad. In: Esposito, John L. (ed.) (2009): The Oxford Encyclopaedia of the Islamic World. New York: Oxford University Press. Vol. 3, p. 252-256.

Petric, Boris (2011): Political games in post-Soviet Uzbekistan. Factions, protection, and new resistances. In: Canfield, Robert L.; RasulyPaleczek, Gabriele (ed.): Ethnicity, Authority and Power in Central Asia. New games great and small. New York: Routledge, Central Asian Studies Series.

Peuch (2004): Turkey: Fethullahci Schools - A Greenhouse For Central Asian Elites? Radio Free Europe/Radio Liberty. Available at: http:// www.rferl.org/content/article/1053209.html (23.8.2013).

Peyrouse, Sébastien (2007): The Rise of Political Islam in Soviet Central Asia. In: Fradkin, Hillel; Haqqani, Husain; Brown, Eric (2007): Current Trends in Islamist Ideology. Washington D.C.: Hudson Institute, Vol. 5., p. 40-54.

Rabb, Intisar A. (2009): Fiqh. In: Esposito, John L. (ed.) (2009): The Oxford Encyclopaedia of the Islamic World. New York: Oxford University Press. Vol. 2, p. 255-258.

Railsback, Steven F. and Grimm, Volker (2012): Agent-Based and Individual-Based Modeling. A Practical Introduction. Princeton: Princeton University Press.

Reporter Ohne Grenzen (2013): Rangliste der Pressefreiheit. Available at: http://www.reporter-ohne-grenzen.de/ranglisten/rangliste-2013/ (8.2. 2014).

RFE/RL - Radio Free Europe/Radio Liberty (2007): Uzbek Election Watchdog Clears Karimov For Third Term. Available at: http://www.rferl.org/content/article/1079156.html (26.6.2014).

RFE/RL - Radio Free Europe/Radio Liberty (2010): Kyrgyz Religious Board Elects New Mufti. Available at: http://www.rferl.org/ content/Kyrgyz_Religious_Board_Elects_New_Mufti/2068567.html (4.10. 2013).

RFE/RL - Radio Free Europe/Radio Liberty (2013): Members of Sufi Group Jailed In Kazakhstan. Available at: http://www.rferl.org/ content/kazakh_sufis_jailed/24365092.html (4.10.2013).

Rickleton, Chris (2013a): Kyrgyzstan: Alternative Medicine Tries to Fill Healthcare Gap. Eurasianet. Available at: http://www.eurasianet.org/ node/67443 (3.10.2013). 
Rickleton, Chris (2013b): Kyrgyzstan: Is Bishkek Stalling on Customs Union?. Eurasianet. Available at: http://www.eurasianet.org/node/67510 (3.10.2013).

Ro'i, Yaacov (2000): Islam in the Soviet Union. From the Second World War to Perestroika. London: Hurst \& Company.

Rotar, Igor (2003): Uzbekistan: Total state control over Islamic faith. Forum 18. Available at: http://www.forum18.org/Archive.php?article_id= 58 (8.11.2013).

Rotar, Igor (2004a): Kazakhstan: Mosques resist pressure to join staterecognised central organisation. Forum 18. Available at: http://www. forum18.org/archive.php?article_id=250 (24.10.2013).

Rotar, Igor (2004b): State Policy Towards Muslims in Central Asia. Islam Daily. Available at: http://www.islamdaily.org/en/world-issues/asiapacific/586.state-policy-towards-muslims-in-central-asia.htm (24.10.2013).

Roy, Olivier (2000): The new Central Asia. The Creation of Nations. London \& New York: I. B. Tauris Publishers.

Roy, Olivier (2004): Globalized Islam : The Search for a New Ummah. The CERI series in comparative politics and international studies. New York: Columbia University Press.

Roy, Olivier (2007): Der falsche Krieg. Islamisten, Terroristen und die Irrtümer des Westens. München: Siedler Verlag.

RT (2009a): 'Rapid response' military base in Kyrgyzstan may be set up within days. Available at: http://rt.com/news/rapid-response-militarybase/ (3.11.2013).

RT (2009b): Additional Russian military forces to be deployed in Kyrgyzstan. Available at: http://rt.com/news/kyrgyzstan-russian-militaryforces/ (22.1.2014).

Salmorbekova, Zumrat and Yemelianova, Galina (2010): Islam and Islamism in the Ferghana valley. In: Yemelianova, Galina (ed.) (2010): Radical Islam in the Former Soviet Union. New York: Routledge. p. 211-243.

Salter, Mark B. (2011): When securitization fails: the hard case of counterterrorism programs. In: Balzacq, Thierry (ed.) (2011): Securitization Theory: How Security Problems Emerge and Dissolve. PRIO New Security Studies. London: Routledge. p. 116-132. 
Schenkkan, Nate (2011a): Kyrgyzstan: Islamic Revivalist Movement Quietly Flourishing. EurasiaNet. Available at: http://www.eurasianet.org/ node/64378 (5.10.2013).

Schenkkan, Nate (2011b): Kyrgyzstan: Hijab Controversy Charges Debate over Islam's Role in Society. EurasiaNet. Available at: http://www. eurasianet.org/node/64306 (6.11.2013).

Schimmel, Annemarie (1985): Mystische Dimensionen des Islam. Die Geschichte des Sufismus. Köln: Eugen Diedrichs Verlag.

Schlageter, Jürg (2003): Zentralasien. Von Marx zu Mohammed. Norderstedt: Books on Demand GmbH.

Schlichte, Klaus (2009): In the Shadow of Violence. The Politics of Armed Groups. Frankfurt/ New York: Campus Verlag.

Schoeberlein, John (2009): Islam in Central Asia and the Caucasus. In: Esposito, John L. (ed.) (2009): The Oxford Encyclopaedia of the Islamic World. New York: Oxford University Press. Vol. 3, p. 98-107.

Schubel, Vernon (2009): Islam's Diverse Paths: Seeking the ,Real Islam in Central Asia. In: Aitpaeva, Gulnara ed. (2009): Sacred Sites of YsykKöl: Spiritual Power, Pilgrimage, and Art. Bishkek: Aigine Research Center.

Schulze, Peter W. (2010): Das Ringen um die zentralasiatischen Energieund Rohstoffreserven. In: Reiter, Erich (ed.) (2010): Konfliktmanagement in Zentralasien. Internationales Institut für Liberale Politik Wien. Schriftenreihe zur internationalen Politik. Wien: Böhlau Verlag. p. 1372.

Schwirtz, Michael (2011): On the Rise in Tajikistan, Islam Worries an Authoritarian Government. New York Times. Available at: http://www.ny times.com/2011/07/17/world/asia/17tajikistan.html?pagewanted=all\&_r $=2 \&(18.9 .2013)$.

Seisenbekova, Zhuldyz (2011a): Hajj will be $\$ 300$ more expensive for Muslims from Kazakhstan in 2011. Tengri News. Available at: http://en.tengrinews.kz/religion/Hajj-will-be-300-more-expensive-forMuslims-from-Kazakhstan-in-2011-5047/ (7.10.2011).

Seisenbekova, Zhuldyz (2011b): Expert: Kazakhstan has become a terminal base for militants of Uzbekistan Islamic Movement. Tengri News. Available at: http://en.tengrinews.kz/military/Expert-Kazakhstan-hasbecome-a-terminal-base-for-militants-of-Uzbekistan-Islamic-4282/ (24.1.2014). 
Shahin, Emad el-Din (2009): Salafiyah. In: Esposito, John L. (ed.) (2009): The Oxford Encyclopaedia of the Islamic World. New York: Oxford University Press. Vol. 5, p. 28-35.

Sheikh, Mona Kanwal (2009): Disaggregating the Pakistani Taliban. Department of Poltiical Science, University of Copenhagen. DIIS Brief. Available at: http://m.diis.dk/files/publications/Briefs2009/Disaggregat ing_Pakistani_Taliban.pdf (8.2.2014).

Sobirov, Ilgizar (2005): Welcome Address by Mr.Ilgizar Sobirov, Chairman of the Senate of the Republic of Uzbekistan. Available at: http:// www.senat.gov.uz/en/index.html (30.9.2013).

Stahel, Albert A. (2002). Dissymmetrischer Krieg versus asymmetrischer Krieg. Sonderbeitrag zur ASMZ, Vol. 168, No. 12, 2002. p. 2-7.

StateDept (2011) Tajikistan 2010. International Religious Freedom Report. Available at: http://www.state.gov/documents/organization/ 171761.pdf (18.9.2013).

StateDept (2012a): Kazakhstan 2012 International Religious Freedom Report. United States Department of State. Available at: http://www. state.gov/documents/organization/208642.pdf (18.9.2013).

StateDept (2012b): Kyrgyz Republic 2012 International Religious Freedom Report. United States Department of State. Available at: http://www.state.gov/documents/organization/208644.pdf (18.9.2013).

StateDept (2012c): Tajikistan 2012 International Religious Freedom Report. United States Department of State. Available at: http://www. state.gov/documents/organization/208654.pdf (18.9.2013).

StateDept (2012d): Uzbekistan 2012 International Religious Freedom Report. United States Department of State. Available at: http://www. state.gov/documents/organization/208658.pdf (18.9.2013).

Sultanov, Asker (2013a): Kyrgyzstan to train terror negotiators. Central Asia Online. Available at: http://centralasiaonline.com/en_GB/articles/ caii/features/main/2013/02/08/feature-01 (29.10.2013).

Sultanov, Asker (2013b): Kyrgyz hold ground on terrorism. Central Asia Online. Available at: http://centralasiaonline.com/en_GB/articles/caii/ features/main/2013/01/24/feature-01 (29.10.2013).

Sultanova, Razia (2007): Female Sufism in Central Asia: from poetry to music. Conference on Music in the world of Islam. Assilah, 8-13 August, 2007. Available at: http://ligne13.maisondesculturesdumonde. org/sites/default/files/fichiers_attaches/sultanova-2007.pdf (9.9.2013). 
Taarnby, Michael (2012): Islamist Radicalization in Tajikistan: An Assessment of Current Trends. Dushanbe: Center for socio-political studies Korshinos. (Supported and funded by the OSCE Office in Tajikistan with a contribution from the Government of Denmark).

Taji-Farouki, Suha (2009): Hizb al-Tahrir al-Islami. In: Esposito, John L. (ed.) (2009): The Oxford Encyclopaedia of the Islamic World. New York: Oxford University Press. Vol. 2, p. 423-426.

TengriNews (2011a): Supreme Mufti called Kazakhstan women to not wear hijabs. Available at: http://en.tengrinews.kz/religion/SupremeMufti-called-Kazakhstan-women-to-not-wear-hijabs-5680/ (9.10.2013).

TengriNews (2011b): Kazakhstan Parliament adopted Religious Law. Available at: http://en.tengrinews.kz/laws_initiatives/Kazakhstan-Parlia ment-adopted-Religious-Law-4754/ (9.10.2013).

TengriNews (2011c): Aktobe Education Department preparing a list of school students wearing hijabs. Availabe at: http://en.tengrinews. kz/people/Aktobe-Education-Department-preparing-a-list-of-schoolstudents-wearing-hijabs-4424/ (9.10.2013).

TengriNews (2012): All good positions in Kazakhstan are held by southern clans. Available at: http://en.tengrinews.kz/politics_sub/All-good-posi tions-in-Kazakhstan-are-held-by-southern-clans-9919/ (9.2.2014).

TengriNews (2013): Spiritual Management of Muslims of Kazakhstan to start issuing fatwas by Shariah laws. Available at: http://en.tengrinews. kz/religion/Spiritual-Management-of-Muslims-of-Kazakhstan-to-startissuing-fatwas-by-Shariah-17165/ (22.1.2014).

TJ MVD* - Tajik Ministry of Interior http://www.vkd.tj/index.php/en/ (26.3.2014).

Toktogulova, Mucaram (2007): Syncretism of Beliefs (Kyrgyzchylyk and Musulmanchylyk). In: Aitpaeva, Gulnara (ed.) (2007): Mazar worship in Kyrgyzstan: Rituals and Practitioners in Talas. Bishkek: Aigine Research Center.

Transparency International (2012): Corruption Perceptions Index 2012 Available at: http://www.transparency.org/cpi2012/results (8.2.2014).

Trend (2011): Commander of special rapid response unit appointed in Kyrgyzstan. Available at: http://en.trend.az/regions/casia/kyrgyzstan/19 14647.html (22.1.2014).

UNECE (2012): Review of Sources and Quality of Statistics on International Migration in selected coutnries of the Commonwealth of Inde- 
pendent States. United Nations Economic Commission for Europe. New York and Geneva: United Nations. Available at: http://www.unece.org/ fileadmin/DAM/stats/publications/Review_of_Sources_on_Internatio nal_Migration_FINAL.pdf (26.6.2014).

USDOS (2012): Country Reports on Terrorism 2012. US Department of State. Available at: http://www.state.gov/j/ct/rls/crt/2012/ (26.6.2014)

Voll, John O. (2009): Sufism: Sufi Orders. In: Esposito, John L. (ed.) (2009): The Oxford Encyclopaedia of the Islamic World. New York: Oxford University Press. Vol. 5, p. 216-225.

Vinson, Mark (2013): Radicalization of Migrant Workers in Russia Could Threaten Stability in Tajikistan. The Jamestown Foundation. Eurasia Daily Monitor. Vol. 10, Issue 146. Available at: http://www.jamestown. org/regions/centralasia/single/?tx_ttnews[tt_news]=41238\&tx_ttnews[b ackPid] $=53 \& \mathrm{cHash}=1 \mathrm{c} 48107951622 \mathrm{c} 928 \mathrm{~b} 2488124 \mathrm{aa7f424 \# .UhtRBD8}$ VXAw (24.1.2014).

Vultee, Fred (2011): Securitization as a media frame: what happens when the media 'speak security'. In: Balzacq, Thierry (ed.) (2011): Securitization Theory: How Security Problems Emerge and Dissolve. PRIO New Security Studies. London: Routledge. p.77-93.

Vuori, Juha A. (2011): Religion bites: Falungong, securitization/ desecuritization in the People's Republic of China. In: Balzacq, Thierry (ed.) (2011): Securitization Theory: How Security Problems Emerge and Dissolve. PRIO New Security Studies. London: Routledge. p. 186-211.

Waldmann, Peter (2003): Das terroristische Kalkül und seine Erfolgsaussichten. In: Schluchter, Wolfgang (ed.). Fundamentalismus, Terrorismus, Krieg. Weilerswist: Velbrück Wissenschaft. p. 87-110.

Weber, Max (1964): The Theory of Social and Economic Organization. In: Talcott Parsons (ed.), (1964). New York: Free Press.

Wendt, Alexander (1995): Constructing International Politics. In: International Security. Vol. 20, No. 1. p. 71-81.

Wenger, Andreas and Zimmermann, Doron (ed.) (2007): How States Fight Terrorism. Policy Dynamics in the West. London: Lynne Rienner Publishers, Inc.

Wilson Center (2011): The Rise of Non-Consensual Bride Kidnapping in Kazakhstan: Developing a Culturally-Informed and Gender-Sensitive Response. Kennan Institute. Kennan Institute. Available at: http://www. 
wilsoncenter.org/publication/the-rise-non-consensual-bride-kidnappingkazakhstan-developing-culturally-informed-and (23.1.2014).

WikiLeaks (2007): Tajik Presidential Protective Service - A Peek Inside. http://www.wikileaks.org/plusd/cables/07DUSHANBE1607_a.html (9.2.2013).

Wilkinson, Claire (2007): The Copenhagen School on Tour in Kyrgyzstan: Is Securitization Theory Useable Outside Europe? Security Dialogue, Vol. 38/2007, No. 1. S. 5-26.

Wilensky, Uri (2013). NetLogo. Center for Connected Learning and Computer-Based Modeling, Northwestern University. Evanston, IL. Available at: http://ccl.northwestern.edu/netlogo/ (9.2.2014).

Wilensky, Uri (2004): NetLogo Rebellion model. Center for Connected Learning and Computer-Based Modeling, Northwestern University, Evanston, IL. Available at: http://ccl.northwestern.edu/netlogo/models/ Rebellion (8.1.2011).

Wilkinson, Claire (2011): The limits of spoken words: from metanarratives to experience of security. In: Balzacq, Thierry (ed.) (2011): Securitization Theory: How Security Problems Emerge and Dissolve. PRIO New Security Studies. London: Routledge. p. 94-115.

WTO - World Trade Organization (2013): WTO Members and Accession Candidates. Available at: http://www.wto.org/english/thewto_e/acc_e/ members_brief_e.doc (30.9.2013).

Yemelianova, Galina (ed.) (2010): Radical Islam in the Former Soviet Union. New York: Routledge.

Yeniseyev, Maksim (2013): Uzbek security services step up anti-terror fight. Central Asia Online. Available at: http://centralasiaonline.com/ en_GB/articles/caii/features/main/2013/07/30/feature-01 (5.2.2014).

Yuldoshev, Avaz (2009a): Hanafi school recognized as official religion of Tajikistan. Asia-Plus. Available at: http://www.news.tj/en/news/hanafischool-recognized-official-religion-tajikistan (18.9.2013).

Yuldoshev, Avaz (2009b): New religion law comes into effect. Asia-Plus. Available at: http://www.news.tj/en/news/new-religion-law-comesaffect (18.9.2013).

Yuldoshev, Avaz (2013): Tajik parliament ratifies agreement allowing Russian troops to stay in Tajikistan until 2042. Asia-Plus. Available at: http://old.news.tj/en/news/tajik-parliament-ratifies-agreement-allowingrussian-troops-stay-tajikistan-until-2042 (9.2.2014). 
ZA - Zentralasien-Analysen (2013): Chronik - Vom 15. Dezember 2012 bis 18. Januar 2013 - Kirgistan. Zentralasien-Analysen, No. 61. Available at:www.laender-analysen.de/zentralasien/pdf/ZentralasienAnalysen61. pdf (9.2.2014).

Zenn, Jacob (2013): Kazakhstan's Counter-Terrorism Strategies for The Post-2013 Security Environment. CACI Analyst. Available at: http:// www.cacianalyst.org/publications/analytical-articles/item/12806-kaz akhstan\%E2\%80\%99s-counter-terrorism-strategies-for-the-post-2013security-environment.html (28.10.2013).

Ziadeh, Farhat J. (2009): Sunni Schools of Law. In: Esposito, John L. (ed.) (2009): The Oxford Encyclopaedia of the Islamic World. New York: Oxford University Press. Vol. 3, p. 389-397.

* further reading 



\section{Appendix}

\section{Appendix A}

The following official documents and websites were used for analysing the Central Asian governments' position towards religion:

Parliamentary Websites of the Central Asian countries:

- Kazakhstan: http://www.parlam.kz/en

- Kyrgyzstan: http://www.kenesh.kg/

- Tajikistan: http://www.parlament.tj/

- Uzbekistan: http://parliament.gov.uz/en/, Senate: http://www.senat. gov.uz/en/index.html

Constitutions of the Central Asian countries:

- Kazakhstan: http://www.din.gov.kz/eng/pravovaja_baza/ ; http://www. constcouncil.kz/eng/norpb/constrk/\#note8anc

- Kyrgyzstan: http://www.legislationline.org/download/action/download/ $\mathrm{id} / 3116 /$ file/Kyrgyz\%20Constitution\%20-\%20adopted\%20by $\% 20$ referendum\%2027\%20Jun2010_f_EN.pdf

- Tajikistan: http://legislationline.org/download/action/download/id/1649/ file/5f95858dea5e2a62de84f0c7f650.pdf

- Uzbekistan: http://legislationline.org/documents/action/popup/id/15850/ preview 
Religious laws of the Central Asian countries: (24.9.2013)

- Kazakhstan: http://www.legislationline.org/download/action/download/ id/4091/file/Kazakhstan_Law_religious_freedoms_organisations_2011_ en.pdf

- Kyrgyzstan: http://www.atc.kg/doc/zkr/3/

- Tajikistan: http://woltj.my1.ru/Doc/ZakPro.pdf

- Uzbekistan: http://religions.uz/rus/normativnaya_baza/zakoni/

Websites of the Religious Committees of Central Asian countries:

- Kazakhstan: http://www.din.gov.kz/eng/index.php (English), http:// www.din.gov.kz/ (Kazakh)

- Kyrgyzstan: not available

- Tajikistan: not available

- Uzbekistan: http://religions.uz/rus

Websites of the Muftiates of Central Asian countries:

- Kazakhstan: http://muftyat.kz/

- Kyrgyzstan: http://muftiyat.kg/

- Tajikistan: not available

- Uzbekistan: http://muslim.uz/ 


\section{APPENDIX B}

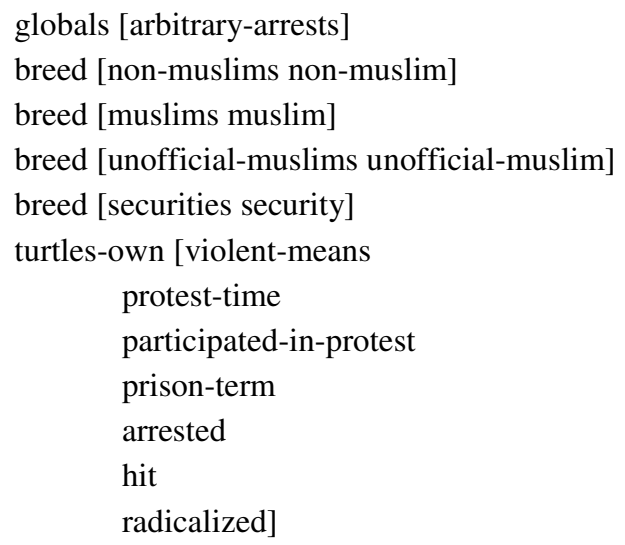


ask one-of unofficial-muslims [set color red set violent-means 1 set size 1.5]

end

to setup-securities

create-securities capacity-securities

ask securities [setxy random-xcor random-ycor]

ask securities [set color 105 set size 1.5]

end

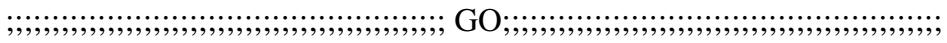

to go

move-turtles

proselytize

protest

arrest

arrest-protestors

attack

radicalize

ask turtles [if hit $>0$ [set hit hit - 1]]

ask turtles [if prison-term $>0$ [set prison-term prison-term - 1]]

ask turtles [if protest-time $>0$ [set protest-time protest-time - 1]]

tick

end

;,;,;,;,;,;,;,;,;,;,;,;,;,;,;,;,;,;,;,;,;,;, MOVE

to move-turtles

ask turtles with [prison-term $=0$ ] with [protest-time $=0$ ] [left random 360 forward 1

end

......,

to proselytize

ask n-of ((count unofficial-muslims with [prison-term $=0$ ] / $(100 *$ context-legitimacy) )+ 1) unofficial-muslims with [prison-term $=0$ ]

[if any? muslims in-radius 1 [ ask one-of muslims in-radius 1 [set color 74 set breed unofficial-muslims]]]

end

ARREST;

to arrest

ask securities [ifelse (count unofficial-muslims $>10 *$ context-legitimacy) 
[ask unofficial-muslims in-radius 1 [ set prison-term 180 ]

ask unofficial-muslims with [violent-means $=1$ ] in-radius 1 [ set prisonterm 180 ]]

[ask unofficial-muslims with [violent-means $=1$ ] in-radius 1 [ set prisonterm 180 ]] ]

ask unofficial-muslims with [color $=74$ ] [if prison-term $=180$ [set arbitrary-arrests arbitrary-arrests +1$]$ ]

end

ARREST PROTESTORS;

to arrest-protestors

ask securities [ask turtles with [color $=$ black] in-radius 1 [set prison-term 40]]

ask turtles with [prison-term $=1]$ [set arrested arrested +1$]$

end

$;, ;, ;, ;, ;, ;, ;, ;, ;, ;, ;, ;, ; ; ;$ PROTEST \& SPROUT JIHADISTS

to protest

ask unofficial-muslims [if any? unofficial-muslims with [prison-term $>0$ ] in-radius 1

[set protest-time 5 set color black set participated-in-protest participated-inprotest +1$]$ ]

ask unofficial-muslims with [protest-time $=0$ ] with $[$ prison-term $=0$ ] $[$ set color 74]

end

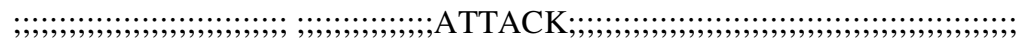

to attack

ask unofficial-muslims with [violent-means $=1$ ] with [prison-term $=0$ ] [if any? securities in-radius 1.2 [ask turtles in-radius 1.2 [set hit 2] set pcolor black ] ]

end

,$;, ;, ;, ;, ;, ;, ;, ;, ;, ;, ;, ;, ;, ;, ;, ;, ;, ;, ;, ;, ;$, RADICALIZE,$;, ;, ;, ;, ;, ;, ;, ;, ;, ;, ;, ;, ;, ;, ;, ;, ;, ;, ;, ; ; ;$

to radicalize

ask turtles with [prison-term $=1$ ] [set radicalized random $10 *$ pts]

ask turtles with [prison-term $=0$ ] [if (radicalized $>=9$ ) [set breed unofficial-muslims set violent-means 1 set color red]]

end 


\section{Appendix C}

Table 37: Initial Values and Parameters for Simulation

\begin{tabular}{|c|c|c|c|c|}
\hline & Kazakhstan & Kyrgyzstan & Tajikistan & Uzbekistan \\
\hline \multicolumn{5}{|l|}{ Initial Values } \\
\hline Security forces & 22.5 & 17 & 10 & 15 \\
\hline Non-Muslims & 1,500 & 1,250 & 300 & 350 \\
\hline Ethnic-Muslims & 3,500 & 3,750 & 4,700 & 4,650 \\
\hline $\begin{array}{l}\text { Religiosity of the } \\
\text { society }\end{array}$ & $1 / 1,000$ & $1 / 1,000$ & $1 / 100$ & $1 / 100$ \\
\hline Jihadists & 1 & 1 & 1 & 1 \\
\hline \multicolumn{5}{|l|}{ Parameters } \\
\hline $\begin{array}{l}\text { Context- } \\
\text { legitimacy }\end{array}$ & 4.25 & 5.00 & 4.25 & 3.5 \\
\hline $\begin{array}{l}\text { Capacities of } \\
\text { Security forces }\end{array}$ & 35 & 11 & 4 & 19 \\
\hline PTS & 2.40 & 2.38 & 2.75 & 2.83 \\
\hline
\end{tabular}

